\author{
UNIVERSIDADE DE SÃO PAULO \\ FACULDADE DE FILOSOFIA, LETRAS E CIÊNCIAS HUMANAS \\ DEPARTAMENTO DE HISTÓRIA \\ PROGRAMA DE PÓS-GRADUAÇÃO EM HISTÓRIA SOCIAL
}

Marina Martins Novaes

Sujeitas de Direitos: história de vida de mulheres bolivianas, peruanas e paraguaias na cidade de São Paulo

São Paulo

2014 


\author{
UNIVERSIDADE DE SÃO PAULO \\ FACULDADE DE FILOSOFIA, LETRAS E CIÊNCIAS HUMANAS \\ DEPARTAMENTO DE HISTÓRIA \\ PROGRAMA DE PÓS-GRADUAÇÃO EM HISTÓRIA SOCIAL
}

\title{
Sujeitas de Direitos: história de vida de mulheres bolivianas, peruanas e paraguaias na cidade de São Paulo
}

\author{
Marina Martins Novaes
}

Dissertação apresentada ao Programa de Pós-Graduação em História do Departamento de História da Faculdade de Filosofia, Letras e Ciências Humanas da Universidade de São Paulo, para obtenção do titulo de Mestre em História.

Orientador: Prof. Dr. Maurício Cardoso.

São Paulo

2014 
Ao Tom, minha alegria de viver 


\section{AGRADECIMENTOS}

A conclusão desta dissertação encerra um ciclo que começou há pelo menos seis anos.

Agradeço à Myriam e a Roberto Novaes, pelo apoio, incentivo e principalmente pelo amor sempre incondicional. Sou muito sortuda de ter vocês como pais. Ao meu irmão Lucas, uma das pessoas de que eu mais gosto de estar perto.

À querida Priscila Siqueira, e toda sua insistência carinhosa para que eu entrasse no mestrado.

Ao Paulo Illes, Roque Pattussi e a toda a equipe do Centro de Apoio ao Migrante e Serviço Pastoral do Migrante. Foram anos basilares da minha vida ter trabalhado com vocês.

Ao meu orientador Maurício Cardoso. Conseguimos!

À professora Mary Anne Junqueira, e aos amigos que fiz quando cursei a sua disciplina: Débora, Valdir, Aruã e a querida Ivania. Ter sido convidada a participar do diretório Trânsito nas Américas, que Mary coordena junto com a Professora Stella Maris Scatena Franco, foi importante para o meu momento acadêmico.

À Stella, agradeço de forma especial pelas contribuições no exame de qualificação, quando dividiu a banca com o Professor José Carlos Sebe Bom Meihy, grande inspirador da metodologia dessa dissertação.

Aos companheiros e companheiras que me ensinam e que compartilham comigo a luta pelo enfrentamento do trabalho escravo e tráfico de pessoas: Estela Scandola, Jaqueline Leite, Marcel Hazeu, Frans Nederstigt, Renato Bignami e Christiane Vieira Nogueira .

Aos queridos amigos e amigas que torcem por mim e que de certa forma acompanharam o desenvolvimento da pesquisa: Pedro Dulci, Maysa Lepique, Silvana Marcondes, Julio Dojcsar, Bianca Pyl, Letícia Massula, Marcelo Pedro, Tatiana Amendola, Bruce Carosini, Lucas Corvacho, Marcela Boni, Paula Neubauer, Marina Gurgel, Débora Donadel, Guta Pacheco, Marcus Vinicius e Tiago Rangel.

Aos meus amigos e amigas da Secretaria Municipal de Direitos Humanos e Cidadania, 
lugar que me orgulho em trabalhar. Saber que perseguimos as mesmas ideias e ideais deixa o ambiente de trabalho leve, mesmo com pautas tão pesadas. Agradeço especialmente à turma do happy hour, Giordano, Letícia, André, Vitor, pois saber que vocês estariam lá para ouvir as minhas angústias e lamentos da dissertação me inspirava!

Às colaboradoras dessa pesquisa, Luzetânia, Nancy, Cris, Dora e Cecília. Cada encontro foi transformador, inspirador e especial. O meu profundo agradecimento por compartilharem suas histórias de vida.

Ao Will, por ser quem é, e por me entender tão bem. A maturidade do nosso amor me dá muita força.

Por fim, agradeço ao Tom Novaes e Silva, que me ensina tanto todos os dias, e que me relembra o que vale a pena. 


\section{RESUMO}

"Sujeitas de Direitos: história de vida de mulheres bolivianas, peruanas e paraguaias na cidade de São Paulo" é uma pesquisa de história oral, guiada por seu conjunto de procedimentos em todas as etapas do trabalho. As entrevistas, a partir da história de vida de cinco mulheres migrantes, seguiram seus pressupostos e formaram o corpo do documento.

Baseado nessas narrativas, feitas de forma colaborativa, buscou-se abordar a história do tempo presente a partir da migração de mulheres que vieram da Bolívia, Paraguai e Peru, e escolheram viver na cidade de São Paulo.

A conquista de espaços urbanos, a liberdade relativa na escolha da profissão e a mobilidade como saída da opressão familiar foram discutidas, ao lado da criação de transnacionalização familiar e das atividades que exploram as vulnerabilidades da pessoa, como o trabalho escravo e o tráfico de pessoas.

Palavras-chave: história oral, migração, gênero, trabalho escravo, tráfico de pessoas. 


\begin{abstract}
"Subject of Rights: the life stories of Bolivian, Peruvian and Paraguayan women in São Paulo" is an oral history research project, guided in its entirety by the method's guidelines. Focused on the life trajectories of five migrant women, the interviews follow the oral history procedures, and interviews also structure the core of the present document.

Grounded on the narratives of these migrants, conducted in a collaborative manner, this projected aimed to tackle the present history of women from Bolivia, Paraguay, and Peru who chose to live in the city of Sao Paulo.

We discuss the seizure of urban spaces, the relative freedom of choice of occupation and mobility as an exit from family oppression, in addition to the conception of household transnacionalization, and finally the activities that endanger the individual, such as slave labor and human trafficking.
\end{abstract}

Key-Words: oral history, migration, gender, slave labour, human trafficking. 


\section{SUMÁRIO}

1 INTRODUÇÃO 9

1.1 As migrações $\quad 16$

$\begin{array}{lll}1.2 & \text { As mulheres que migram } & 23\end{array}$

1.3 As histórias de vida 30

$\begin{array}{lll}1.4 & \text { As colaboradoras } & 35\end{array}$

2 A MIGRAÇÃO EM SUAS HISTÓRIAS 38

2.1 Dora Coronil Palacios $\quad 38$

2.2 Cecília Lumbreras $\quad 58$

3 O TRABALHO E A MIGRAÇÃO EM SUAS HISTÓRIAS

3.1 Maria Cristina Romero Alvarez $\quad 81$

$\begin{array}{lll}3.2 & \text { Luzetânia Quino Flores } & 97\end{array}$

$\begin{array}{lll}3.3 & \text { Nancy Pasis Perla } & 118\end{array}$

4 ELAS QUE MIGRAM 130

$\begin{array}{lll}4.1 & \text { Elas que vivem a vida transnacional } & 137\end{array}$

4.2 Elas que trabalham $\quad 142$

$\begin{array}{ll}\text { 4.2.1 Trabalho forçado } & 147\end{array}$

4.2.2 A relação entre as formas de trabalho forçado 157

5 CONSIDERAÇÕES FINAIS 161

$\begin{array}{ll}\text { REFERÊNCIAS } & 164\end{array}$ 



\section{INTRODUÇÃ̃ ${ }^{1}$}

A ideia inicial desta pesquisa nasceu em 2008, a partir do trabalho de assistência jurídica a migrantes sul-americanos na organização não governamental Centro de Apoio ao Migrante (CAMI), ligada ao Serviço Pastoral dos Migrantes, situada no bairro do Pari, na cidade de São Paulo. Diariamente bolivianos, peruanos e paraguaios nos procuravam com demandas de violação de direitos dos quais julgavam não serem titulares por não estarem com seu status migratório regular. Explicávamos que todos e todas têm garantias previstas por instrumentos jurídicos nacionais, como a Constituição Federal, e por tratados internacionais de Direitos Humanos, na tentativa de iniciar um processo de inserção sociopolítica e de regularização migratória de cada novo migrante. A partir desses atendimentos, desenvolvemos uma escuta muito peculiar, onde ouvíamos suas histórias, que possuíam em comum a vontade de proporcionar uma vida melhor para si e suas famílias.

Pareceu-nos importante que, entre as pessoas atendidas, mais de 58\% fossem mulheres. Fato corroborado pelas estatísticas de organismos internacionais, como as Nações Unidas, que apontam que há 214 milhões de migrantes no mundo e que elas representam $49,6 \%$ do total. $^{2}$

Se por um lado muitas apareciam com seus companheiros, que faziam todo o trabalho de falar por elas, outras iam sozinhas com assuntos que variavam desde pensão alimentícia até tráfico de pessoas, passando pela falta de acordos trabalhistas, problemas relacionados a serviços de consumo, violência doméstica, entre outros.

Graduei-me em Direito, e a escolha por esta profissão se justificou ao considerar o contexto de vulnerabilidade e ineficiência da aplicação das leis de forma igualitária no Brasil e pela possibilidade de promover o acesso à justiça dos grupos vulneráveis, vítimas de violações de direitos.

Orientada pelo pensamento feminista, sempre militei pela superação das desigualdades e discriminações de gênero, raça e etnia. E minha trajetória profissional

\footnotetext{
${ }^{1} \mathrm{O}$ título desta dissertação remete à Revolução Francesa, quando Olympe de Gouges (1748 - 1793), feminista, historiadora e jornalista, elaborou a Declaração dos Direitos da Mulher e da Cidadã, a qual criticava a Declaração dos Direitos do Homem e do Cidadão de 1789, que não considerava as mulheres como sujeitas de direitos iguais aos dos homens. O texto de Olympe foi rejeitado por unanimidade pela Assembleia Nacional Francesa em 1791. A proponente foi posteriormente levada à guilhotina no período do Terror.

${ }^{2}$ UNFPA. State of World Population 2011: People and Possibilities in a World of 7 Billion. Disponível em: <http://www.unfpa.org/swp/2011>. Acesso em: 09 mai. 2012.
} 
seguiu este curso, em um primeiro momento com o trabalho para a efetivação dos direitos humanos de meninas, mulheres e trans ${ }^{3}$ vítimas ou possíveis vítimas de tráfico de pessoas. Depois com migrantes, homens e mulheres corajosos, que decidiram viver em outro país, enfrentando muitas vezes situações de violação de direitos.

Essa trajetória, aliada à ideia de estudar fenômenos históricos, especificamente a história do tempo presente, me fez encontrar na história oral um caminho para tratar da história de vida de mulheres migrantes.

E desse universo de atendimentos jurídicos, com um olhar na história do tempo presente, chegamos a uma problemática de pesquisa focada na análise da trajetória de mulheres bolivianas, paraguaias e peruanas que migraram para a cidade São Paulo, entre 2000 e 2010, sozinhas, sem sua família ou seu companheiro, trazendo na bagagem expectativas e sonhos, recheadas de histórias tristes, mas também de superação.

Embora pressões econômicas motivem a iniciativa de migrar, há outros fatores que também influenciam a tomada de decisão de morar em outro país. Concordamos com Póvoa Neto e Ferreira que "o deslocamento espacial de populações pode representar tanto uma tentativa de resolução de problemas - individuais, coletivos, sociais - quanto um motivo de preocupação para determinados segmentos". ${ }^{4}$ Ou seja, não há uma, mas várias questões migratórias.

Ao analisar cada caso, Thomson pontuou que "o testemunho pessoal revela o complexo entrelaçamento de fatores e influências que contribuem para a migração e para os processos de troca de informações e negociação no interior das famílias e das redes sociais". 5

A historiadora francesa Isabelle Bertaux-Wiame ${ }^{6}$, ao ouvir as histórias de vida de mulheres migrantes dentro da França, apurou que, apesar das motivações econômicas serem

\footnotetext{
${ }^{3}$ Segundo a pesquisadora Adriana Piscitelli, o termo "trans" é um termo êmico que se refere ao conjunto de pessoas consideradas travestis, transexuais ou transgêneros. In: PISCITELLI, Adriana. Sujeição ou Subversão? Migrantes Brasileiras na Indústria do Sexo na Espanha. In: Revista História e Perspectivas, ${ }^{\circ} 35$, Uberlândia-MG: Universidade Federal de Uberlândia, 2006. p.15. ${ }^{4}$ PÓVOA NETO, Helion; FERREIRA, Ademir P. (Orgs). Cruzando Fronteiras disciplinares. Um panorama dos estudos migratórios. Rio de Janeiro: Revan, 2005. p. 11.

${ }^{5}$ THOMSON, Alistair. Histórias (co) movedoras: História oral e estudos de migração. In: Rev. Bras. Hist., 2002, vol.22, no.44. p.341-364.

${ }^{6}$ BERTAUX-WIAME, Isabelle. The Life History Approach to the Study of Internal Migration. In Oral History vol. 7, $\mathrm{n}^{\mathrm{o}}$ 1, 1979. p. 26-32.
} 
similares, os métodos, as condições e o significado da migração de homens e de mulheres são distintos. Para ela, os homens se movimentam através da rede familiar para encontrar trabalho, e as mulheres se movimentam através do trabalho para dar sentido à rede familiar. Esse seu estudo, com o enfoque na natureza das relações de gênero, percebeu que as mulheres enfatizam a importância das relações sociais sobre a "agência social autônoma evidente nas histórias dos homens".

Enraizado na heterogeneidade histórica das diferentes sociedades, os movimentos migratórios expressam uma dinâmica presente ao longo da humanidade.

Conforme Octavio Ianni, a contemporaneidade aparece como resultado de uma nova etapa do capitalismo, denominada globalização, que afirma um "novo ciclo de expansão do capitalismo, como modo de produção e processo civilizatório de alcance mundial". ${ }^{8}$

Nesse panorama da globalização, as migrações internacionais são parte do cenário mundial e questão central no mundo pós-colonial. Articulado ao desenvolvimento tecnológico, das comunicações, dos transportes e inserido nas transformações econômicas sociopolíticas, a mobilidade e o deslocamento tornam-se as formas compensatórias para a sobrevivência e reprodução econômica das famílias, indivíduos e grupos humanos, buscando acomodação, emprego e subsistência. ${ }^{9}$

Seguindo essa concepção teórica, Saskia Sassen vê facilidades que estimulam a migração de mulheres, membros do novo proletariado global, para países desenvolvidos. A partir da última década do século XX, ela constata que há uma presença crescente das mulheres em uma grande variedade de circuitos "transfronteiriços", o que ela conceitualmente forjou como "contrageografias da globalização". Ela também discute a construção deste processo de globalização como consequência de inclusões desiguais e precárias destas trabalhadoras:

[...]a última década tem mostrado uma presença crescente de mulheres em um amplo leque de circuitos transfronteiriços. Embora muito diversos, esses circuitos compartilham uma característica: são rentáveis e geram

\footnotetext{
${ }^{7}$ THOMSON, op. cit., p. 347.

${ }^{8}$ IANNI, Octavio. A era do Globalismo. Rio de Janeiro: Civilização Brasileira, 1996. p.11.

${ }^{9}$ Ibidem, p. 171 .
} 
lucros à custa de quem está em condições desvantajosas. Incluem o trânsito ilegal de pessoas destinadas a indústria do sexo e a variados tipos de trabalho no mercado formal $\mathrm{e}$ informal. Incluem as migrações transfronteiriças, com ou sem a posse de documentos legais, que têm sido uma fonte importante de divisas para os governos dos países de origem. ${ }^{10}$

Para Abdelmalek Sayad, há países que são ao mesmo tempo de emigração e de imigração, de acordo com a posição que ocupam no plano internacional e no sistema mundial de relações de força entre Estados. Sayad ainda argumenta que em qualquer nível socioeconômico em que se situem os países, este duplo fenômeno de emigração (a partir de países "pobres em trabalho assalariado") e imigração (para países "pobres em mão de obra e ricos em empregos") é um indicador do desenvolvimento desigual, que separa países, assim como da assimetria flagrante das relações de força, que opõem os países em categorias de dominantes e dominados. ${ }^{11}$

É o caso do Brasil, que experimentou a emigração de brasileiros para os países ricos no Norte, e a imigração de pessoas de países mais pobres, notadamente da América do Sul e da África. Nosso país possui atrativos derivados da qualidade de vida, mas também apresenta problemas de ordem social e econômica, o que faz muitos nacionais saírem do país.

Estima-se que cerca de 2 milhões de brasileiros residam no exterior, enquanto cerca de 1,5 milhão de estrangeiros vivem em situação regular no Brasil, segundo dados oficiais. Dos que entram no país, a maioria são de origem portuguesa, boliviana, chinesa e paraguaia. $^{12}$

As pessoas nascidas na Bolívia, Paraguai e Peru e residentes no Brasil têm aumentado em volume nas últimas duas décadas. Dados do censo demográfico de 2000 registraram que, entre os anos 1990 e 2000, a taxa de crescimento anual da população

\footnotetext{
${ }^{10}$ SASSEN, Saskia. Contrageografias de la globalización. Género y ciudadanía en los circuitos transfronterizos. Madrid: Traficantes de Sueños, 2003. p 41.

${ }^{11}$ SAYAD, Abdelmalek. O retorno: elemento constitutivo da condição do imigrante. In: Travessia - Revista do Migrante, São Paulo, Centro de Estudos Migratórios, n.1, especial, janeiro 2000. p. 08.

${ }^{12}$ Dados disponíveis no site do Ministério da Justiça.

$<$ http://portal.mj.gov.br/data/Pages/MJA5F550A5ITEMIDF7B2EE1D60D4405F80C9C91D4EA12FC3PTBR

NN.htm>. Acesso em 21 jun. 2012.
} 
boliviana foi de $2,95 \%$, a paraguaia de $4,73 \%$, e a peruana $7,1 \%{ }^{13}$

Contudo, os dados oficiais deixam escapar uma parte significativa desta população migrante, por viverem em situação indocumentada. Segundo o Ministério da Justiça, em 2011 viviam no Brasil pouco mais de 50 mil bolivianos, 17 mil paraguaios e 17 mil peruanos. ${ }^{14}$ Estimativas do Serviço Pastoral do Migrante/CAMI apontam que mais de 300 mil migrantes sul-americanos estão no país, especificamente na Grande São Paulo, em situação migratória irregular. ${ }^{15}$

Esta invisibilidade acentua ainda mais a condição de vulnerabilidade, esta não como sinônimo de fraqueza, mas sim de uma situação de impotência imposta pela estrutura de poder, de muitos destes migrantes indocumentados, cuja "inexistência estatística" aprofunda, segundo Sayad, as contradições entre o direito e o fato, criando uma intensa instabilidade na experiência do imigrante:

[...] não se sabe mais se se trata de um estado provisório que se gosta de prolongar indefinidamente ou, ao contrário, se se trata de um estado mais duradouro mas que se gosta de viver com um intenso sentimento de provisoriedade. ${ }^{16}$

No campo jurídico internacional, Gabriela Rodríguez Pizarro, relatora especial sobre os Direitos Humanos dos Migrantes (1999-2005), apontou em seu primeiro informe sobre os Direitos Humanos dos Migrantes que não existe um conceito jurídico sobre o que é ser migrante, e propõe que migrantes sejam considerados como aqueles que estão fora do território de sua nacionalidade ou cidadania. ${ }^{17}$ Ao longo do nosso estudo, adotaremos o termo migrante ou migração, o qual será trabalhado melhor no subcapítulo a seguir. Muitas vezes as mulheres migrantes enfrentam dois tipos de vulnerabilidade: por sua condição de

\footnotetext{
${ }^{13}$ SALA, Gabriela Adriana e CARVALHO, José Alberto Magno de. A presença de imigrantes de países do Cone Sul no Brasil: medidas e reflexões. In: Rev. bras. estud. popul. [online]. 2008, vol.25, n.2, pp. 287-304. ISSN 0102-3098. Disponível em: <http://dx.doi.org/10.1590/S0102-30982008000200006>. Acesso em: 14 mai.2012.

${ }^{14}$ Disponível em: < www.mj.gov.br>. Acesso em 23 jun. 2012.

${ }^{15}$ ZOCCHIO, Guilherme. "Se trabalharmos só no horário comercial, não recebemos nada". Repórter Brasil, São Paulo, 27 de ago. 2012. Disponível em: <http://www.reporterbrasil.org.br/exibe.php?id=2101>. Acesso em: 30 ago. 2012 .

${ }^{16}$ SAYAD, Abdelmalek. A imigração ou os paradoxos da alteridade. São Paulo, Edusp, 1998.

${ }^{17}$ RODRIGUEZ, Gabriela P. Derechos Humanos de los Migrantes. Informe apresentado à Comissão de Direitos Humanos, $56^{\circ}$ período de sessões, Nova York, Nações Unidas. p.3.
} 
gênero e por serem migrantes. Situações que são levantadas como bandeiras na luta pela equidade de direitos políticos econômicos e sociais, bem como pela igualdade de oportunidades em educação e emprego.

A Declaração Universal dos Direitos Humanos, de 1948, marco jurídico para a proteção da tutela dos direitos fundamentais, representa um marco internacional para a garantia da proteção geral com base na igualdade formal de todas e todos.

Contudo, é insuficiente tratar os indivíduos de forma genérica e abstrata, e tratá-los da mesma forma, pelas suas peculiaridades e particularidades, pois determinados sujeitos de direitos, ou determinadas violações de direitos, exigem uma resposta específica e diferenciada, ${ }^{18}$ como é o caso das crianças e adolescentes, indígenas, afrodescendentes e as mulheres, por exemplo.

Neste contexto, ao afirmar-se que o direito das mulheres são direitos humanos, querse dizer que, para gozar desta proteção, deve-se observar as especificidades e peculiaridades de sua condição social. E ainda deve-se levar em conta que ao lado do direito à igualdade, há o direito à diferença, que implica o direito ao reconhecimento de identidades próprias e assegura um tratamento especial. Como aponta Boaventura de Sousa Santos:

[...] as pessoas e os grupos sociais têm o direito a serem iguais quando a diferença os inferioriza, e o direito a serem diferentes quando a igualdade os descaracteriza. ${ }^{19}$

Para o referido autor, os Direitos Humanos só poderão exercer o seu caráter emancipatório e de garantias se de um lado forem genuinamente multiculturais e abandonarem a perspectiva universalista e, de outro, forem acompanhados de políticas sociais que minimizem a desigualdade e a exclusão.

Mas para ele, que toma como pressuposto que o paradigma da modernidade converge para o capitalismo, tanto a desigualdade como a exclusão são sistemas hierárquicos de pertencimento. A desigualdade implica num sistema hierárquico de

\footnotetext{
${ }^{18}$ PIOVESAN, Flavia. Direitos sociais, econômicos e culturais e direitos civis e políticos. In: Sur, Rev. int. direitos humanos. vol.1, n.1 São Paulo, 2004.

${ }^{19}$ SANTOS. Boaventura de Sousa. Por Uma Concepção Multicultural de Direitos Humanos. In: Lua Nova, revista de Cultura Política. Centro de Estudos de Cultura Contemporânea. São Paulo. 1997. p. 56.
} 
integração social, onde a presença daquele que está por baixo é indispensável. E a exclusão, também hierarquizada, é regida pela própria exclusão: quem está por baixo, está fora. ${ }^{20}$

As comunidades migrantes que analisamos se inserem nestes dois sistemas, seja por estarem numa relação desigual da relação capital-trabalho, que culmina com a exploração laboral, seja por não estarem totalmente incluídas cultural e socialmente. E ainda estão sujeitas a outra forma de hierarquização que contém elementos destes dois sistemas: o racismo e o sexismo.

Segundo Sousa Santos, o universalismo surge como dispositivo ideológico contra a desigualdade e a exclusão, caracterizando-se a partir de duas formas: o universalismo antidiferencialista, que nega as diferenças e o universalismo diferencialista, que as absolutiza. Se o primeiro descaracteriza as diferenças e as verticaliza, inferiorizando pelo excesso de semelhança, o outro nega as hierarquias que organizam as diferenças e inferioriza pelo excesso de diferença. ${ }^{21}$

Sob a égide de princípios de cidadania e direitos humanos, o universalismo confronta a desigualdade com políticas sociais gerais e abstratas, e a exclusão com políticas de reinserção social. Este viés de assimilação acompanha uma homogeneização que ignora as especificidades e particularidades.

O sociólogo português aponta ainda que, além de camponeses e indígenas, os migrantes e as mulheres são também objeto de políticas homogêneas vinculadas ao universalismo antidiferencialista. No caso das mulheres, a partir do momento em que direitos de cidadania foram conferidos, e elas entraram no mercado de trabalho, passaram do sistema de exclusão para o da desigualdade.

Assim, não só as mulheres, mas crianças e adolescentes, população afrodescendente, migrante, entre outros grupos, devem ser vistos nas suas especificidades. Ao lado do direito à igualdade, deveria se constituir o direito à diferença com a especificação do sujeito de direito, que passa a ser visto em sua peculiaridade e sua particularidade.

As políticas específicas de visibilidade e o reconhecimento de identidades diversas a grupos vulneráveis têm se constituído como desafio relevante para a implementação dos

\footnotetext{
${ }^{20}$ Ibidem, p. 2.

${ }^{21}$ Ibidem, p.6.
} 
direitos humanos. Um conjunto razoável de convenções e acordos internacionais tem sido aprovado nas últimas décadas, colocando em pauta a situação específica de grupos como mulheres, crianças e migrantes. ${ }^{22}$

A Declaração de Direitos Humanos de Viena, de 1993, responde a este anseio com um duplo legado, ao prever em seu artigo 18 que os direitos humanos das mulheres e das meninas são parte inalienável, integral e indivisível dos direitos humanos universais. Endossa assim a inalienabilidade e indivisibilidade de Direitos Humanos, conforme a Declaração Universal de Direitos Humanos (1948) já previu; e também afirma o processo de especificação do sujeito. $^{23}$

Apesar dos pequenos avanços referentes às políticas migratórias, a imigração feminina constitui ainda um impasse para as políticas de Estado e para a legislação internacional sobre direitos humanos, visto que prevalece ainda uma perspectiva universalista que, via de regra, oculta as desigualdades pelo véu da diferença.

\subsection{As migrações}

As migrações movem aqueles que aspiram por uma vida melhor e que são impulsionados pela vontade de desenvolvimento, satisfação de anseios de liberdade e de necessidades intrínsecas aos seres humanos, como trabalho, moradia, saúde, entre outras. Para muitos migrantes a mudança para um outro país é motivada também pela busca de crescimento pessoal, acesso à educação, à segurança e a possibilidades efetivas de sucesso.

A migrações coexistem com a história da civilização e têm suas peculiaridades conforme o período histórico. Para Park, as migrações modernas são caracterizadas pelo fato de atingir todas as pessoas, com as mais diversas motivações, especialmente de cunho

\footnotetext{
${ }^{22}$ Em 1989 a ONU adotou a Convenção sobre os Direitos da Criança; um ano depois o Brasil promulgou o Estatuto da Criança e do Adolescente. Também em 1990 a ONU aprovou a Convenção Internacional sobre a Proteção dos Direitos de Todos os Trabalhadores Migrantes e dos Membros das suas Famílias. Quanto às mulheres, para citar alguns documentos, em 1979 é aprovada a Convenção sobre a Eliminação de todas as formas de Discriminação contra a Mulher, em 1993 tem-se a Declaração sobre a Eliminação da Violência contra a Mulher, e em 2000 foi adotado o Protocolo Adicional à Convenção das Nações Unidas contra o Crime Organizado Transnacional Relativo à Prevenção, Repressão e Punição do Tráfico de Pessoas, em Especial Mulheres e Crianças. No Brasil, a Lei 11.340/2006 (Lei Maria da Penha) cria mecanismos para coibir a violência doméstica e familiar contra a mulher.

${ }^{23}$ Para a Declaração de Direitos Humanos de Viena acessar:

$<$ http://www.direitoshumanos.usp.br/index.php/Sistema-Global.-Declarações-e-Tratados-Internacionais-deProteção/declaracao-e-programa-de-acao-de-viena.html>.
} 
privado, que se movem à procura de condições mais favoráveis, o que implica no mínimo a mudança de residência, a ruptura e a criação de novos vínculos sociais. ${ }^{24}$

Para guiar este trabalho, iremos usar o termo "migrações" a partir dos entendimentos da Organização Internacional para as Migrações (OIM), traduzido pela equipe do Centro Scalabriniano de Estudos Migratórios (CSEM) de alguns termos do "Glosario sobre migración". ${ }^{25}$ Para a OIM, migração é:

\begin{abstract}
Movimento de população para o território de um outro Estado ou dentro do mesmo que abrange todo movimento de pessoas, seja qual for o tamanho, sua composição ou suas causas; inclui a migração de refugiados, pessoas deslocadas, pessoas desarraigadas, migrantes econômicos.
\end{abstract}

Esta escolha foi feita por entender a migração como um ir ou sair para talvez ficar ou voltar, em permanente movimento, pois a pessoa que migra não sabe o tempo que vai ficar nem para onde irá depois. E o migrante nunca deixa suas origens completamente.

Em um recorte brasileiro, por quatro séculos o Brasil recebeu a migração forçada da África, consequência do tráfico de escravos. A abolição da escravidão que atendeu interesses econômicos, descolada de qualquer planejamento ou política social que integrasse os libertos, fez com que os ex-escravos continuassem à margem da sociedade, alijados econômica e socialmente, se deslocando para as periferias urbanas.

Seguido ao descobrimento do Brasil, começaram a aportar os primeiros portugueses. Porém, foi no século XVII que a vinda se tornou significativa, e assim transcorreu até a primeira metade do século XIX.

Na virada do século XIX para o XX, junto com os Estados Unidos e a Argentina, o Brasil incentivou e atraiu uma considerável migração de trabalhadores europeus, dado a conjuntura externa, aliada à uma política de embranquecimento. O país recebeu também pessoas vindas da Ásia (como os japoneses) e do Oriente Médio, ampliando a diversidade étnica com o crescimento das chamadas identidades hifenizadas (nipo-brasileiro, libanês-

\footnotetext{
${ }^{24}$ PARK, Robert. Human Migrations and the Marginal Man. In: The American Journal of Sociology, vol. 33, $\mathrm{n}^{\circ} 6.1928$.

${ }^{25}$ Derecho Internacional sobre Migración, n. 7. Genebra: OIM, 2006. Disponível em:

$<$ http://www.csem.org.br/pdfs/conceitos_basicos_de_migracao_segundo_a_oim.pdf> Acesso em: 29 ago 2013.
} 
brasileiro), resultado da negociação entre sua identidade nacional e a assimilação das diferenças culturais da sociedade brasileira. ${ }^{26}$

Na segunda metade do século XX, o Brasil teve uma notável migração interna, na qual grandes contingentes populacionais deslocaram-se do campo para a cidade, bem como de regiões menos desenvolvidas e mais pobres, para regiões mais dinâmicas economicamente. ${ }^{27}$ Um exemplo deste fluxo interno são as e os migrantes nordestinos que se dirigiam para cidades como São Paulo e Rio de Janeiro.

Na década de 1980, iniciou-se o fluxo da migração sul-americana ao Brasil, que se intensificou no começo do século XXI. ${ }^{28}$ Oriundos principalmente da Bolívia, Paraguai e Peru, são migrantes que não tiveram a sua migração estimulada, a exemplo daqueles do início do século XX. Segundo o antropólogo Sidney Antonio da Silva, o perfil característico destes é: jovem, de ambos sexos, solteiros, de escolaridade média e tem o fator econômico como principal objetivo de deslocamento. ${ }^{29}$

Muitos destes migrantes, especificamente bolivianos, antes de chegarem ao Brasil passaram também por uma migração interna, do campo para a cidade, e posteriormente para outro país, em geral à procura de trabalho. Em São Paulo, trabalham em pequenas oficinas de costura escondidas pela megalópole paulistana, geralmente em condições precárias. Caminho parecido, porém em menor escala, percorrem paraguaios e peruanos. ${ }^{30}$

A migração intrarregional na América Latina e Caribe é antiga e tem origem na heterogeneidade econômica e social dos países, aliada à proximidade geográfica e cultural, o que tornou possível o movimento entre países vizinhos antes mesmo dos processos de

\footnotetext{
${ }^{26}$ LESSER, Jeffrey. A negociação da identidade nacional: imigrantes, minorias e a luta pela etnicidade no Brasil. Trad. Patrícia de Queiroz C. Zimbres. São Paulo: Editora da UNESP, 2001.

${ }^{27}$ COMISSÃO NACIONAL DE POPULAÇÃO E DESENVOLVIMENTO. ORGANIZAÇÃO INTERNACIONAL PARA AS E MIGRAÇÕES E MINISTÉRIO DO TRABALHO E EMPREGO. Perfil Migratório do Brasil 2009. OIM Publications, 2010. p.16.

${ }^{28}$ BAENINGER, Rosana e SOUCHAUD, Sylvain. Vínculos entre a migração internacional e a migração interna: o caso dos bolivianos no Brasil In: OFICINA NACIONAL SOBRE MIGRACIÓN INTERNA Y DESARROLLO EN BRASIL: DIAGNÓSTICO, PERSPECTIVAS Y POLITÍCAS, Brasília, 2007.

${ }^{29}$ SILVA, Sidney Antonio da. Bolivianos em São Paulo: entre o sonho e a realidade. In: Estud. av. [online]. 2006, vol.20, n.57, pp. 157-170. Disponível em: <http://dx.doi.org/10.1590/S0103-40142006000200012>. Acesso em 09 set. 2012

${ }^{30}$ ILLES, Paulo.; TIMÓTEO, Gabriela. L. S.; FIORUCCI, Eliana da S. Tráfico de pessoas para fins de exploração do trabalho na cidade de São Paulo. In: Cadernos Pagu, Campinas: Unicamp/NEG, n. 31, 2008, p. 205.
} 
integração e de livre comércio. ${ }^{31}$

Durante as duas últimas décadas (1990-2010), a migração dentro da região aumentou sensivelmente, indicando que a mobilidade pelos vários países tem se tornado uma estratégia importante para diversos setores sociais. Estimativas das Nações Unidas indicam que nos anos 2000, 21.381 milhões de pessoas, ou seja, 4,1\% do total de pessoas da América Latina e Caribe, viviam fora do seu país de nascimento. ${ }^{32}$ Esta tendência tem sua base na estrutura e nas dinâmicas dos próprios países da região, que constantemente mudam de acordo com o estágio de desenvolvimento em que cada país se encontra, a exemplo do que foi a migração interna do campo para a cidade motivada pelo acelerado processo de urbanização iniciado na década de $1930{ }^{33}$

A mobilidade de migrantes da própria região também se relaciona com os limites geográficos e a integração sub-regional em blocos, que tendem a propiciar a progressiva liberação de mobilidade. Argentina, Costa Rica e Venezuela são os países com maior atração migratória na região, segundo o Observatório Demográfico para a América Latina e Caribe, das Nações Unidas. Já a Colômbia, Paraguai, Nicarágua, Bolívia e Chile são os países que mais têm migrantes espalhados pela região. ${ }^{34}$

Mas as condições que desencadeiam o deslocamento podem ser diversas das razões que permitem o fenômeno continuar no tempo e no espaço. Algumas teorias foram desenvolvidas para responder por que alguns fluxos migratórios se mantêm, mesmo que em escalas e níveis diferentes.

O sociólogo espanhol Sánchez Barricarte diz em sua teoria das redes que, uma vez iniciados os primeiros fluxos migratórios, os migrantes vão estabelecendo redes de relações interpessoais, que aumentam as probabilidades dos migrantes que chegam ou planejam se mudar de diminuírem o custo e o risco da permanência. ${ }^{35 .}$ Nesta esteira, essas redes consolidam a assistência, disseminam informações e diminuem o custo do deslocamento,

\footnotetext{
${ }^{31}$ MARTÍNEZ, Jorge e VONO, Daniela. Geografía migratoria intraregional de América Latina y el Caribe al comienzo del siglo XX. In: Revista de Geografia Norte Grande, Santiago, Chile, n. 34, dezembro de 2005, p.45.

${ }^{32}$ ECLAC. 2006 International Migration. Latin America and the Caribbean Demographic Observatory. Santiago do Chile: United Nations, ECLAC. p.16.

${ }^{33}$ Ibidem, p. 24.

${ }^{34}$ MARTÍNEZ, Jorge e VONO, Daniela, 2005,op. cit., p.46.

${ }^{35}$ SÁNCHEZ BARRICARTE, Jesús Javier. Socioeconomía de las migraciones en un mundo globalizado. Madrid: Biblioteca Nueva, 2010. p.31-32.
} 
bem como as incertezas e inseguranças dos novos migrantes.

A teoria do capital social apresentada permite revelar como as redes sociais dos migrantes utilizam o capital social, esse como conjunto de recursos intangíveis das famílias e das comunidades que têm a capacidade de se converter em outras formas de capital. ${ }^{36}$

Conforme Ribas, essa teoria considera o fator educativo como fundamental na seleção de trabalhadores e na sua adaptação econômica no país de destino. ${ }^{37}$ A perspectiva da rede e do capital social permitem olhar a migração considerando não somente fatores macro, como os estruturais ou o de expulsão e atração, mas também a escolha racional e orientada pelo interesse pessoal.

É imprescindível considerar, ao se falar em migração, o contexto de luta e compromissos internacionais para a ampliação e efetivação dos direitos humanos dos e das migrantes, bem como reconhecer o papel dos Estados e de suas políticas sociais. Ainda "há que se considerar que os movimentos migratórios internacionais constituem a contrapartida da reestruturação territorial planetária intrinsecamente relacionada à reestruturação econômico-produtiva em escala global". ${ }^{38}$

De uma perspectiva global, uma em cada 33 pessoas vive, atualmente, num país diverso do qual nasceu. ${ }^{39}$ Embora as migrações acompanhem a história, a aceleração dos deslocamentos humanos transformou-as em grande tema de Estado.

Os governos essencialmente tratam as e os migrantes sob dois enfoques: recebê-los como trabalhadores ou como estrangeiros. Porém, se por um lado ser trabalhador evoca direitos como os sociais, políticos e culturais, ser estrangeiro pode trazer a conotação de "estranhamento".

De fato, do latim extra - fora, extraneus - estranho, exter - de fora, o termo enfatiza o caráter de ser diferente dos outros.

E a migração, independente se seu motivo for econômico como consequência das

\footnotetext{
${ }^{36}$ Ibidem, p. 31.

${ }^{37}$ RIBAS MATEOS, Natalia. Una invitación a la sociologîa de las migraciones. Barcelona: Bellaterra, 2004. p 78-80.

${ }^{38}$ BAENINGER, Rosana e PATARRA, N. L.. Migrações internacionais, globalização e blocos de integração econômica: Brasil no Mercosul. In: Alejandro I. Canales. (Org.). Panorama actual de las migraciones en America Latina. Guadalajara: Universidad de Guadalajara, 2006, v.1 p. 118.

39 http://www.iom.int/jahia/Jahia/about-migration/facts-and-figures/lang/en. Acesso em 02 jun. 2012.
} 
desigualdades na distribuição da riqueza mundial, ou por subsistência, ou para fugir de conflitos armados, ou ainda por mudanças climáticas, ela tem em comum a busca por trabalho e vida digna. A liberdade e o direito fundamental de ir e vir é a base da luta por dignidade, como enumera o artigo XIII da Declaração Universal dos Direitos Humanos. ${ }^{40}$

Perceber a e o migrante como estrangeiro no sentido de estranho ou adversário toma ainda mais relevo após o atentado de 11 de setembro nos Estados Unidos e a estratégia militar preventiva iniciada com a Guerra no Afeganistão, os conflitos do Oriente Médio, as tensões entre comunidades de migrantes muçulmanos na Europa, entre outras manifestações das contradições e conflitos que permeiam a vida coletiva neste início de século, reforçando também as dimensões de racismo e xenofobia. ${ }^{41}$

O escopo da segurança nacional justifica políticas de migração que sacrificam valores democráticos com o pretexto de preservá-la. Como é o caso da "Diretiva de retorno" na Comunidade Europeia, ${ }^{42}$ que criminaliza migrantes indocumentados por permitir a sua detenção por até 18 meses, e a Lei Arizona nos EUA de $2010,{ }^{43}$ que tipificava como delito a condição migratória irregular e o fato de transportar e dar emprego a migrantes sem documentos. A Lei foi derrubada parcialmente em 2012 pela Suprema Corte daquele país, por entenderem que a polícia do Arizona não pode prender sem mandado a pessoa que não estiver com seus documentos migratórios em situação regular. Mas manteve a possibilidade da polícia checar o status migratório de qualquer pessoa. ${ }^{44}$

A América do Sul, tanto no âmbito da União das Nações Sul-Americanas (UNASUL), como do Mercado Comum do Sul (MERCOSUL), opôs-se ao recrudescimento da política restritiva da migração no Hemisfério Norte. Mas, reflexos destes mitos, cristalizados pelos países desenvolvidos, de que estrangeiros/as são pobres ou delinquentes, são sentidos em países em desenvolvimento, como o Brasil.

De acordo com o Relatório de Desenvolvimento Humano de 2009, do Programa das

\footnotetext{
40 “Artigo XIII: 1. Toda pessoa tem direito à liberdade de locomoção e residência dentro das fronteiras de cada Estado. 2. Toda pessoa tem o direito de deixar qualquer país, inclusive o próprio, e a este regressar."

${ }^{41}$ VENTURA, Deisy. e ILLES, Paulo. Estatuto do estrangeiro ou lei de imigração?. Le Monde Diplomatique Brasil. Agosto de 2010, p. 14-15.

${ }^{42}$ Diretiva 2008/115/CE, relativa a normas e procedimentos comuns nos Estados-membros para o retorno dos nacionais de terceiros países em situação irregular (16/12/08). Disponível em http://www.migrarconderechos.es/legislationMastertable/legislacion/Directiva_2008_115

${ }^{43}$ Lei SB 1070 de 23/04/10 do Estado do Arizona (Estados Unidos).

${ }^{44}$ Informação disponível em www.bbc.co.uk/portuguese/noticias/2012/06/120625_arizonalei_pu.shtml, Acesso em 21 mar. 2014.
} 
Nações Unidas para o Desenvolvimento (PNUD) ${ }^{45}, 43 \%$ dos brasileiros e brasileiras são a favor de limitar ou proibir a imigração. Outros 45\% dizem que o Brasil deve "permitir que as pessoas cheguem desde que haja empregos disponíveis". Apenas 9\% acreditam que se deve permitir a entrada de qualquer pessoa que deseje imigrar ao país.

No âmbito de políticas migratórias, o Brasil tem avanços como a Lei de Anistia Migratória (Lei $\mathrm{n}^{\mathrm{o}} 11.961$, de 2 de julho de 2009). No mesmo ano, entrou em vigor o Acordo de Livre Residência para nacionais do MERCOSUL, Chile e Bolívia (Decretos $\mathrm{n}^{\circ}$ 6.964/2009 e nº 6.975/2009), que em 2011 teve adesão do Peru e em 2012, da Colômbia. O Acordo exige a apresentação de documentos de identificação, atestado de antecedentes criminais e pagamento de taxas, e concede a residência temporária por dois anos, que poderá ser transformada em permanente desde que comprovado possuir meios de subsistência.

Porém, ainda está em vigência, como política migratória a Lei $\mathrm{n}^{\circ} 6.815$, de 19 de agosto de $1980{ }^{46}$ chamada de Estatuto do Estrangeiro. Resquício da época do regime militar, primando pela segurança nacional, a lei vigente garante ao Estado a possibilidade de discriminar, punir ou retirar do país qualquer estrangeiro que o Poder Executivo considerar uma ameaça. Além de arbitrária, a lei não segue os tratados e convenções de Direitos Humanos dos quais o Brasil é signatário. A própria Constituição Brasileira (1988), tida como democrática e com forte ênfase nos direitos humanos, em seu art. 22, XV, se limita a dizer que "compete à União legislar sobre emigração e imigração, entrada, extradição e expulsão de estrangeiros".

O Ministério da Justiça em 29 de maio de $2013^{47}$ constituiu uma Comissão de Especialistas para apresentar proposta de anteprojeto do que chamou de "Lei de Migrações e Promoção dos Direitos dos Migrantes no Brasil”. Os trabalhos da comissão serão focados no direito dos migrantes, na entrada de estrangeiros no país, na presença de brasileiros no exterior e na emissão de vistos.

O Conselho Nacional de Imigração (CNIg), órgão criado pelo Estatuto do Estrangeiro, vinculado ao Ministério do Trabalho e Emprego, é composto por representantes governamentais e de entidades de trabalhadores e empregadores. Tem por finalidade, entre

\footnotetext{
${ }^{45}$ PNUD. Relatório de Desenvolvimento Humano 2009. Ultrapassar Barreiras: Mobilidade e desenvolvimento humanos. Nova Iorque. 2009.

${ }^{46}$ Lei disponível em http://www.planalto.gov.br/ccivil_03/leis/16815.htm. Acesso em 26 set. 2012.

${ }^{47}$ Disponível em http://migre.me/is0C7. Acesso em 22 mar. 2014.
} 
outras, elaborar a política migratória e promover diversas atualizações na lei, através de Resoluções Normativas. Tais Resoluções operam como paliativos ao Estatuto do Estrangeiro, por não alterar a essência da lei e não revogar suas disposições.

Igual retrocesso é a não assinatura da Convenção Internacional das Nações Unidas sobre a Proteção dos Direitos dos Trabalhadores Migrantes e dos Membros das suas Famílias, de 1990, principal norma referente à matéria. O Brasil é o único país do MERCOSUL que não a ratificou.

Neste sentido veremos que ainda faltam políticas que deem condições e efetividade de permanência no Brasil, e que respondam por anseios no território por meio do que Patarra $^{48}$ atribuiu a uma política de gestão imigratória e não de controle imigratório, isto é, os Estados devem continuar sua atribuição de regular a entrada de pessoas no território e supervisionar sua admissão e permanência, mas com o olhar para uma política ativa para todos aqueles que pretendam migrar.

Nesta perspectiva regional, as fronteiras constituem-se como peças fundamentais para compreender e descrever a dinâmica da realidade sul-americana. Não somente pensando nas fronteiras geográficas entre os países, mas também nas fronteiras internas, entre o urbano e o rural, nas fronteiras imaginárias criadas a partir das histórias de quem migrou, ou pelas fronteiras culturais e étnicas interpretadas a partir deste movimento.

As fronteiras, entendidas tanto como parte do espaço político, como parte dos grupos socioculturais, são representadas de modo objetivo e subjetivo, pela estrutura percebida, construída e modificada por diferentes atores e atrizes sociais, que se constituem com traços específicos e se distanciam da representação social genérica que os vê como sujeitos indiferenciados e abstratos.

\subsection{As mulheres que migram}

Como mencionado, o Relatório sobre a Divisão de População das Nações Unidas (UNFPA) de 2010 aponta que, atualmente, há 214 milhões de migrantes no mundo. O

\footnotetext{
${ }^{48}$ PATARRA, Neide Lopes. Migrações Internacionais: teorias, políticas e movimentos sociais. In: Estudos Avançados. São Paulo, v. 20, n 57, agosto 2006. Disponível em: <http://migre.me/is09d>. Acesso em: 22 mar. 2014.
} 
estudo revela que 49,6\% do total dos migrantes são mulheres. Na América Latina e Caribe, o número de mulheres migrantes é de $50,1 \%{ }^{49}$

As Nações Unidas apontam para o aumento no número de mulheres migrantes na América do Sul, tendência constatada em outras partes do mundo. Segundo a edição de 2006 do mesmo relatório, a migração das mulheres pode ser entendida como uma porta para outras possibilidades:

For many women, migration opens doors to a new world of greater equality, relief from oppression and the discrimination that limits freedom and stunts potential. For origin and receiving countries, the contribution of women migrants can quite literally transform quality of life. ${ }^{50}$

Há estudos que falam da migração como um fenômeno crescente e que tem tendido a feminizar-se como resposta, entre outros fatores, à incorporação das mulheres nas atividades produtivas remuneradas. $^{51} \mathrm{O}$ Centro Latino-americano e Caribenho de Demografia (CELADE) assinala que as dificuldades de absorção laboral nos países de origem, em contraponto com as facilidades tecnológicas que possibilitam a migração e a comunicação entre os lugares de origem e destino, e a existência das redes tecidas pelas comunidades migrantes, incentivam esse processo. ${ }^{52}$

Segundo o relatório da ONU, tão importante quanto o volume crescente das migrantes em deslocamento são as especificidades do fenômeno migratório, em suas diferentes intensidades e espacialidades e em seus impactos diferenciados. O estudo aponta que muitas destas mulheres são migrantes econômicas, mas este deslocamento não está

\footnotetext{
${ }^{49}$ UNFPA. State of World Population 2011: People and Possibilities in a World of 7 Billion. Disponível em: <http://www.unfpa.org/swp/2011>. Acesso em: 09 mai. 2012.

${ }^{50}$ UNFPA. State of World Population 2006: A Passage to Hope: Women and International Migration. Disponível em: <http://www.unfpa.org/swp/2006/>.

${ }^{51}$ ZLOTNIK, Hania, The global dimensions of female migration Migration Information Source.. In: Migration Policy Institute, Washington, D.C., 2003. Disponível em: $<$ www.migrationinformation.org/Feature/print.cfm?ID=109>. Acesso em: 23 mai. 2012.; CASTELLANOS, Patricia Cortés. Mujeres migrantes de América Latina y el Caribe: derechos humanos, mitos y duras realidades. In: Programa Regional de Población y Desarrollo Centro Latinoamericano y Caribeño de Demografia (CELADE) - División de Población / Fondo de Población de las Naciones Unidas. Santiago do Chile, 2005. p. 23.; OSO CASAS, Laura. Movilidad laboral de las mujeres latinoamericanas en España y empresariado étnico. In: Familias, niños, niñas y jóvenes migrantes: rompiendo estereotipos. Madrid: Iepala editorial, 2010. pp. 33-46.

${ }^{52}$ CASTELLANOS, 2005, op. cit., p. 9.
} 
ligado apenas aos benefícios econômicos. Este processo também representa o rompimento com uma trajetória de subordinação, para começar uma outra, em que a mulher migrante tem a possibilidade de escrevê-la sozinha. ${ }^{53}$

Assim, esta pesquisa procurou analisar as transformações provocadas pelas migrações na organização das famílias das mulheres imigradas, nas suas escolhas profissionais e na articulação com a rede social. Procuramos identificar, pelas histórias de vida, que novos significados sobre a condição da mulher foram produzidos no percurso de migração e estabelecimento na cidade de São Paulo de bolivianas, paraguaias e peruanas.

A feminização da migração é uma expressão usada para reforçar o fenômeno de uma perspectiva de gênero e criar uma sensibilização para o assunto. ${ }^{54}$ Como apontam pesquisas dos organismos internacionais, ${ }^{55}$ o termo muitas vezes é interpretado de maneira quantitativa, mas de uma forma geral as mulheres sempre representaram uma parte significativa nos movimentos migratórios. Porém, a própria migração era vista como um fenômeno masculino. Zlotnik afirma que até o final dos anos 1970 boa parte dos estudos em migração internacional era focado em migrantes homens, ou assumiam que a maioria dos migrantes eram homens. ${ }^{56}$

O papel da mulher como coadjuvante, ou sua imagem como submissa e incapaz de tomar decisões, é uma representação, e já foi desmontada por muitos trabalhos historiográficos, como aponta Maria Ligia Coelho Prado. ${ }^{57} \mathrm{Em}$ sua pesquisa, ela remete-se ao século XIX e demonstra que este lugar da mulher "parece mais uma vez contrariar as construções oficiais da história" e aponta "pistas que revertem a perspectiva de alheamento da mulher das coisas públicas". 58

Beatriz Sarlo, no artigo "Mulheres, História e Ideologia", diz que a mulher ainda não é vista totalmente fora da sombra do homem, mas que as mudanças das últimas décadas permitem enxergá-la: “a mulher pode não representar a humanidade como ocorre com o

\footnotetext{
${ }^{53}$ UNFPA, 2006, op. cit, p.31.

${ }^{54}$ ENGLE, Lauren B. The World in Motion: Short Essay on Migration and Gender. Genebra: IOM, 2004. p. 5.

${ }^{55}$ Ibidem, p.6 e UNFPA, 2006, p. 34.

${ }^{56}$ Zlotnik, 2003, op.cit., p. 23.

${ }^{57}$ PRADO, Maria Ligia C. Em busca da participação política das mulheres nas lutas pela independência da América Latina. In: Revista Brasileira de História. São Paulo, n. 23/24, 1992, p. 77-90.

${ }^{58}$ Ibidem, p. 78.
} 
homem, mas ela não é mais excluída do civitas". 59 .

Segundo Lauren Engle, a feminização das migrações pode ser relacionada com o avanço das mulheres nos países desenvolvidos. Ela cita como exemplo as mulheres de Singapura na década de 1980, que começaram a ter mais oportunidades de trabalho. Este avanço trouxe oportunidades para a migração de mulheres filipinas, para trabalhar com serviços domésticos, como cuidadoras de crianças, de idosas e idosos, ou para trabalhar como empregadas domésticas. ${ }^{60}$

A América Latina foi a primeira região do mundo em que houve a paridade no número entre homens e mulheres migrantes. Em 1990, dos 6 milhões de migrantes internacionais, 3 milhões eram mulheres. Os números de 2000 confirmam a tendência. ${ }^{61}$

Dados de 2008 da Comissão Econômica para a América Latina e o Caribe (CEPAL) também mostram que os principais fluxos no continente são predominantemente femininos. Ainda com o crescimento econômico e com o aumento de mulheres participando do mercado de trabalho na América do Sul, a demanda por serviços domésticos também cresceu, como aconteceu em países desenvolvidos. Dessas migrantes, 27\% estão empregadas em serviços domésticos. Algumas nacionalidades registram uma porcentagem maior, como o caso das colombianas, guatemaltecas, nicaraguenses, paraguaias e peruanas. ${ }^{62}$

E também se deve levar em conta que o aumento da participação das mulheres na migração internacional tem dois principais processos: as mudanças de papéis, especificamente a maior participação das mulheres na esfera pública (o que inclui sustentar economicamente a família) e o aumento da demanda de trabalho para migrantes em serviços como o doméstico e de cuidados. ${ }^{63}$

O crescimento da participação das mulheres, no que Marcela Cerruti chamou de esfera pública, não é apenas o resultado de mudanças entre os papéis dos homens e

\footnotetext{
${ }^{59}$ SARLO, Beatriz. Mulheres, História e Ideologia. In: SARLO, Beatriz. Paisagens Imaginárias. Edusp. São Paulo. 2005. p. 172.

${ }^{60}$ ENGLE, 2004, op.cit., p. 6.

${ }^{61}$ Zlotnik, 2003, op. cit. 26.

${ }^{62}$ MARTÍNEZ PIZARRO, Jorge. América Latina y el Caribe: migración internacional, derechos humanos y desarrollo. Santiago do Chile: División de Población / Fondo de Población de las Naciones Unidas, 2005.

${ }^{63}$ CERRUTTI, Marcela. Gender and Intra-regional regional migration in South America. In: United Nations

Development Programm, Human Development Research Papers, dezembro de 2009.
} 
mulheres, mas também uma real necessidade de aumentar o orçamento doméstico. O papel do homem que historicamente foi demandado como o de prover o sustento da família, um dos aspectos centrais do patriarcalismo, é anacrônico e não reflete a realidade. ${ }^{64}$

Nos anos 1990 até o final do século XX, as taxas de participação das mulheres, de idade entre 15 a 65 anos, como força de trabalho, aumentou em todos os países da América Latina, chegando a 49\% ao fim de 1999. Nos casos dos países de emigração, o aumento da força de trabalho feminina aumentou significativamente. Entre 1990 e 2007, estas taxas aumentaram de $46,6 \%$ para $54,7 \%$ na Bolívia; de $50,6 \%$ para $56,1 \%$ no Paraguai, de $45,7 \%$ a 54\% na Colômbia e 43,2 para 53,7\% no Equador. ${ }^{65}$

Como consequência, as mulheres ganharam mais responsabilidades para sustentar suas famílias, e também uma certa autonomia nas decisões. E no contexto da divisão de trabalho por sexo, encontra-se a migração autônoma das mulheres.

Parreñas fala em servants of globalization ${ }^{66}$ para se referir às mulheres que se deslocam para trabalhar como empregadas domésticas. Ehrenreich e Hochschild falam em global women $^{67}$ para referir-se a babás, domésticas e trabalhadoras sexuais. À parte as relações de gênero, estes dois termos implicam que o processo de globalização pode reforçar as relações de desigualdade entre as mulheres, ao reconhecer determinados direitos por parte de alguns grupos em detrimento dos direitos de outros. Ou seja, se de um lado há mulheres bem-sucedidas, de outro estão aquelas que dependem da comercialização do serviço doméstico para sobreviver, deixando de lado a sua própria vida. Em ambos estudos, mulheres migrantes ocupam o posto de babás, empregadas e profissionais do sexo para receber baixos salários e exercerem profissões não qualificadas.

O trabalho gerado pelas mulheres que migram para trabalhar no mercado informal produz recursos econômicos que, dada a sua natureza, ficam invisibilizados e favorecem a redução dos custos de produção, a flexibilização e a desregulamentação da força de trabalho. Para Sassen essa precarização "crea condiciones para la absorción de mano de obra

64 Ibidem, p.23.

65 SASSEN, 2003, op. cit., p. 23.

${ }^{66}$ PARREÑAS, Rhacel Salazar. Servants of Globalization: Women, Migration, and Domestic Work. Londres: Stanford University Press, 2001.

${ }^{67}$ EHRENREICH, Barbara e HOCHSCHILD, Arlie Russel. Global women: nannies, maids and sex workers in the new economy. Nova Iorque: Henry Holt and Company, 2002. 
femenina y extranjera". ${ }^{6}$

Deve-se ressaltar que a grande presença das mulheres na migração regional deve-se também à relativa facilidade de entrar e permanecer no país como migrantes irregulares. ${ }^{69}$ Carolina Rosas demonstra em seu estudo que, quando os riscos envolvendo a travessia de fronteiras são baixos, as mulheres constituem uma boa parte do número de migrantes. Ao contrário, se os riscos de ser pego são maiores e passíveis de abusos ou punições, o número de mulheres não é tão expressivo, como no caso da migração do México para os EUA. ${ }^{70}$

Portanto, as leis migratórias, os controles da fronteira e os custos de permanecer sem documentos são elementos que também devem ser considerados para explicar a presença mais relevante das mulheres nos fluxos migratórios.

E este fenômeno deve estar aliado a uma visão de gênero ou mesmo um tratamento diversificado na construção de políticas públicas. Se para as mulheres migrantes há uma abertura à autonomia econômica e a novos espaços de participação social, há também novas formas de controle social, ${ }^{71}$ sendo necessário que os governos tenham um olhar para as relações de gênero e gerem políticas necessárias para o desenvolvimento com igualdade e equidade entre os homens e mulheres migrantes.

Ao examinar o processo da migração de mulheres da América do Sul para São Paulo, a partir da heterogeneidade das migrações de bolivianas, peruanas e paraguaias, três das mais significantes correntes migratórias na capital paulista, pretendemos discutir quais foram as mudanças de paradigma neste contexto de migrações e de que modo essas mulheres assumem determinados papéis na vida familiar e na condução de seu próprio destino no percurso migratório.

A ampliação do seu papel na organização de suas famílias, as transformações nas relações com os maridos e os filhos e a condição da maternidade a longa distância expressam os dilemas dessas mulheres ao reorganizar suas vidas no novo país. Por meio das

\footnotetext{
${ }^{68}$ SASSEN, 2003, op. cit., p. 18.

${ }^{69}$ Conforme dados da ONU, em 1980 a proporção de mulheres entre os e as migrantes internacionais em todo o mundo foi de $47,4 \%$, enquanto entre os e as imigrantes sul-americanas foi de 50,8\%. Disponível em:

$<$ http://esa.un.org/migration/index.asp?panel=1>.

${ }^{70}$ ROSAS, Carolina. ¿Migras tú, migro yo o migramos juntos? Los condicionantes de género en las decisiones migratorias de parejas peruanas destinadas en Buenos Aires. In: JORNADAS ARGENTINAS DE ESTUDIOS DE POBLACION (AEPA), 9, Huerta Grande, Córdoba, 31 de Outubro a 2 de Novembro de 2007.

${ }^{71}$ Como, por exemplo, as campanhas de restrição à migração para a pretensa prevenção ao tráfico de mulheres para fins sexuais.
} 
histórias de vida, procuramos analisar não apenas o fenômeno econômico que, muitas vezes, impulsionou a decisão inicial dessas mulheres, mas também a construção de autonomia e a emancipação que nascem das experiências migratórias. Pretendemos também investigar em que medida esses deslocamentos podem mudar a relação com as sociedades de origem e como essas mulheres identificavam sua própria condição.

Para entender e interpretar a trajetória destas mulheres e a construção de significados analisaremos questões como: a maternidade à distância e a relação e manutenção das famílias transnacionais, que substituem os beijos e abraços por conversas ao telefone, e quando possível pela internet. Verificaremos também o papel das remessas, quantidade de dinheiro enviada para o país de origem.

Atividades que exploram as vulnerabilidades da mulher, como o trabalho escravo e o tráfico de pessoas, serão abordadas em uma perspectiva que José de Souza Martins ${ }^{72}$ chama de inclusão subordinada. Isso significa que o termo "excluído" falseia uma inclusão, determinada pela exploração e subordinação. Ambos os crimes têm a migração como pano de fundo, e, na lógica do autor, as pessoas, e nesse trabalho especificamente as mulheres migrantes, se subordinam a situações de exploração de sua força de trabalho para garantir a inclusão como forma de acesso à economia.

Pretendemos também verificar se a conquista de espaços urbanos, a liberdade relativa na escolha da profissão, a mobilidade como saída da opressão familiar, a fuga da dominação masculina, são fatores positivos e também propiciadores para a migração feminina.

E ainda a articulação com as redes sociais, isto é, as comunidades de migrantes, como elemento facilitador da adaptação através da estratégia de grupos familiares e de amizade em que estão inseridas, e que possibilitam a relação destino e origem e a continuação do fluxo de migração.

Queremos interpretar histórias de vidas e avaliar a forma e os limites com os quais essas mulheres procuraram modificar as representações e o papel que lhes foram atribuídos em função da etnia, do gênero ou da classe.

\footnotetext{
${ }^{72}$ MARTINS, José de Souza. O problema das migrações no limiar do terceiro milênio. In: Vários autores. $\mathbf{O}$
} Fenômeno Migratório no Limiar do Terceiro Milênio: desafios pastorais. Petrópolis, RJ: Vozes, 1998, p.22. 


\subsection{As histórias de vida}

Marc Bloch definiu que a história é "ciência dos homens no tempo". 73 A vontade de pontuar que também é a "ciência das mulheres no tempo" me levou ao estudo de História. Contribuiu para a delimitação da pesquisa as cifras indicadoras de que as mulheres já são mais do que a metade de todos os migrantes internacionais no mundo. A isso aliou-se o fato de estarmos na cidade de São Paulo, que recebe diariamente centenas de mulheres migrantes intrarregionais, com histórias de vida que passam por opressão e discriminação, e que almejam um novo mundo de igualdade e liberdade.

A migração feminina não parte de um modelo uniforme de representação da mulher. Ainda que definidas pelo sexo, as mulheres migrantes são mais do que uma categoria biológica; elas existem socialmente e compreendem pessoas do sexo feminino de diferentes idades, de diferentes situações familiares, pertencentes a diferentes classes sociais, nações e comunidades. Não são somente "mulheres", mas também mães, irmãs, filhas, esposas, sobrinhas, que fazem a primeira etapa de um projeto da família, para criar as raízes no país de destino.

E elas possuem condições familiares distintas. Muitas são solteiras, outras são casadas e partem sem seus esposos; algumas vão com a ajuda de familiares que facilitam a sua ida, e ainda há aquelas que migram devido a problemas nas relações familiares. E esta decisão de migrar não é sempre uma decisão individual, muitas são estratégias de um projeto familiar.

As dificuldades e o confronto com uma sociedade diferente da sua ajudam a compor esta nova identidade, levando em conta a pluralidade de fatores identitários, que recebe influências do meio em que estas migrantes se encontram, em um processo de mescla cultural.

Suas identidades estão em transformação, assim como as oportunidades que aparecem ao mudarem paradigmas. Mantendo sua bagagem cultural, social e étnica, suas vidas são modeladas por diferentes regras sociais e costumes, em um meio em que se configuram crenças e opiniões decorrentes de estruturas de poder. Ao formar esta nova

\footnotetext{
${ }^{73}$ BLOCH, Marc. Apologia da História. Rio de Janeiro: Jorge Zahar, 2001. p. 55.
} 
maneira de representação, enriquecem a sua cultura original com a do país de acolhida, e se instrumentalizam para obter o reconhecimento e a integração necessários para o objetivo migratório.

Estas peculiaridades de cada migrante implicam o que Stuart Hall entende como "deslocamento ou descentração do sujeito", ou seja, a compreensão de si como sujeito sem uma identidade fixa, essencial ou permanente, no seu lugar no mundo social e cultural. Em seu texto Quem precisa de identidade?, o crítico cultural jamaicano estabelece que identidades:

[...] não são unificadas; que elas são, na modernidade tardia, cada vez mais fragmentadas e fraturadas; que não são, nunca, singulares, mas multiplamente construîdas ao longo de discurso, práticas e posições que podem se cruzar ou ser antagônicos. As identidades estão sujeitas a uma historicização radical, estando constantemente em processo de mudança e transformação. $^{74}$

Segundo Michael Pollack, ${ }^{75}$ a memória é um elemento constitutivo do sentimento de identidade, na medida em que ela é um fator extremamente importante para a continuidade e coerência de uma pessoa ou de um grupo em sua reconstrução de si. Essa construção não está isenta de mudanças, de negociação e de transformação em função do outro, confirmando a hipótese de Hall.

Assim, a memória pode constituir um elemento importante para o reconhecimento e a valorização de indivíduos ou grupos, como um trabalho de manutenção, de renovação, de coerência, de continuidade e de organização.

Partindo da premissa de Hobsbawm que "toda história é história contemporânea disfarçada", ${ }^{76}$ ao se escrever sobre o nosso próprio tempo, é inevitável que a experiência pessoal modele a maneira como a vemos e como a avaliamos, evidenciando a maneira a qual

\footnotetext{
${ }^{74}$ HALL, Stuart. Quem precisa da identidade? In: SILVA, Tomaz Tadeu da e Woodward, Kathryn (Orgs.). Identidade e Diferença: a perspectiva dos estudos culturais. Rio de Janeiro: Vozes, 2000.

${ }^{75}$ POLLAK, Michael. Memória, Esquecimento, Silêncio. In: Estudos Históricos. Rio de Janeiro, vol.2, n. 3, 1989. p. 3-15.

${ }^{76}$ HOBSBAWM, Eric. O Presente como História. In: Sobre História. São Paulo: Companhia das Letras, 2005. p. 245.
} 
devemos recorrer para apresentá-la.

Pensando no movimento atual de mulheres que figuram como representantes de sua história, as suas memórias, anseios, representações e estratégias podem ser a base para sustentar a narrativa sobre o passado e o presente. O que foi lembrado, as circunstâncias dos fatos evocados, e como foi contado, são elementos da narrativa que nascem na memória e se projetam na imaginação. A articulação destes elementos pode se materializar na representação verbal e ser transformada em fonte escrita. Nesta transposição, a memória é um suporte para narrativas de história.

É desta forma que a História Oral surge nesta pesquisa como fundamento teórico capaz de inserir as mulheres migrantes como sujeito nos discursos, com luz no processo histórico, dada a diversidade das suas trajetórias de vida. E a partir das interpretações sobre esses deslocamentos, analisaremos a sua inclusão neste processo.

Para José Carlos Sebe Bom Meihy, a condição de repensar e significar o passado a partir do presente, e a de estabelecer os espaços capazes de dar sentido e explicações aos atos sociais das pessoas são pontos principais da história oral, que "herdam os dilemas e as benesses da vida no presente". ${ }^{77}$

Assim, essa metodologia nos parece fundamental para investigar os aspectos de vivência, de valores e de trajetórias pessoais, como elementos reveladores dos processos históricos no nível da micro-história, no sentido de permitir dar voz aos anônimos, e situar o foco no particular, cuja abordagem "deve permitir o enriquecimento da análise social, tornála mais complexa, pois leva em conta aspectos diferentes, inesperados, multiplicados da experiência coletiva". ${ }^{78}$

Se por um lado a história oral esclarece e dá voz, por outro respeita as diferenças e facilita a compreensão das identidades, pois todos são personagens históricos, e o cotidiano e grandes fatos podem se contrapor na medida que se entrecruzam para garantir a lógica da vida coletiva.

Para abordar a história oral dessas migrantes, nos basearemos, além de nas

\footnotetext{
${ }^{77}$ MEIHY, José Carlos Sebe Bom. Manual de histó ria oral. São Paulo: Edições Loyola, 2005. p.24.

${ }^{78}$ LEVI, Giovanni. A herança imaterial: trajetória de um exorcista no Piemonte do século XVII. Rio de Janeiro: Civilização Brasileira, 2000. p. 272.
} 
informações técnicas para os procedimentos em entrevistas e projetos, na reflexão sobre a memória, dentro da perspectiva de um conjunto teórico que transforma esta metodologia em ação com fins políticos. Paul Thompson é um dos que pensam como desafio para a História Oral uma das finalidades sociais essenciais: dar voz aos sujeitos. ${ }^{79}$ Trazendo à tona estas vozes, revelam-se os projetos de transformação social.

Sônia Maria de Freitas também vai neste sentido em que a valorização das experiências de indivíduos e grupos e de suas trajetórias e expectativas faz com que historiadores encarem a necessidade de recuperar as mais diversas histórias, vindo de encontro com a constituição de uma sociedade plural e democrática, por "produzir novas fontes históricas, valorizando expressões culturais ou resgatando cidadania". ${ }^{0}$

Nesta linha do caráter social da História Oral está também José Carlos Sebe Bom Meihy. E é dele a metodologia que utilizamos nesta dissertação, a partir da qual a transcrição de uma fonte oral para a linguagem escrita requer uma adaptação para o novo formato documental. ${ }^{81}$ Ele propõe para este processo a etapa de transcriação do texto original, cabendo ao pesquisador organizar, corrigir erros e acrescentar detalhes da oralidade que se perdem no papel, como interjeições, choros, risos e silêncio, isto é, capturar situações que sejam essenciais para compreender o que o entrevistado quis dizer. E aqui, as fontes documentais são estas transcriações feitas a partir de registro fonográfico, transformadas em textos escritos, inseridas na íntegra em suas versões finais.

Nos ativemos também à potencialidade epistemológica da História Oral, ou seja, no seu condão de revelar saberes e produzir conhecimento. Aí entra a perspectiva de Thompson em estudar uma "história vista de baixo" (history from below) ${ }^{82} \mathrm{E}$, assim, tratar a história oral das mulheres a partir da feminização das migrações, como um instrumento para pautar as mulheres e incluí-las na historiografia, como forma de dar voz para aquelas que nem sempre foram as principais nas páginas da história.

Segundo Philippe Joutard, ${ }^{83}$ o interesse pela história das mulheres desempenhou um importante papel para o reconhecimento da história oral, quer se trate da vida cotidiana, do

\footnotetext{
${ }^{79}$ THOMPSON, Paul. A voz do passado: história oral. 3. ed. Rio de Janeiro: Paz e terra, 1992.

${ }^{80}$ FREITAS, Sônia Maria de. História Oral. Possibilidades e procedimentos. São Paulo: Humanitas, 2006.

${ }^{81}$ MEIHY, 2005, op. cit. e Reintroduzindo História Oral no Brasil. São Paulo: Xamã, 1996.

${ }^{82}$ THOMPSON, 1992, op. cit.

${ }^{83}$ JOUTARD, Philippe. História oral: balanço da metodologia e da produção nos últimos 25 anos. In: FERREIRA, Mariete de Moraes e AMADO, Janaína (Orgs.). Uso e abusos da História oral. 7 ed. Rio de Janeiro: Fundação Getúlio Vargas, 2005. p. 43-62.
} 
trabalho operário ou doméstico, da militância ou, mais profundamente, de sua identidade ou de sua vida afetiva.

O artigo de Sherna Gluck "What's so special about women: women's oral history" ${ }^{\prime 84}$ foi pioneiro para o estudo da história oral das mulheres. Aliás, ela usa o termo "história oral feminista". Na introdução do artigo, ela argumenta:

Refusing to be rendered historically voiceless any longer, women are creating a new history - using our own voices and experiences. We are challenging the traditional concepts of history, of what is "historically important", and we are affirming that our everyday lives are history. Using an oral tradition, as old as human memory, we are reconstructing our own past. ${ }^{85}$

Neste trabalho encontramos na História Oral a forma de poder retratar os sentidos vividos e as experiências dessas mulheres em todo o seu processo de migração. Ela também foi subsídio teórico importante para estudar esse movimento, a partir da reconstrução das trajetórias de vida, da inserção em uma ambiente diferente, do diálogo com a cidade, na aquisição de direitos e na inserção no mundo laboral. Procuramos apurar a partir desse desafio a nossa capacidade de reflexão e de pesquisa e, ao mesmo tempo, propor e viabilizar as novas abordagens.

E foi a partir da metodologia da História Oral que procuramos compreender a particularidade deste fenômeno migratório e, a partir dos temas que surgiram, buscamos o que havia sido produzido pela historiografia e por outras áreas formais do conhecimento. $\mathrm{O}$ constante diálogo entre as fontes orais e as discussões teóricas e científicas sobre temas, como migrações, trabalho análogo ao de escravo, tráfico de pessoas, família transnacional, processo de integração da sociedade brasileira, preconceito e discriminação, entre outros, revela como essas questões ganham interpretações variadas nas vozes das migrantes e como as experiências individuais são formadoras de uma experiência coletiva comum e, ao mesmo tempo, heterogênea. E ainda: a análise do fenômeno migratório, feita a partir das narrativas

\footnotetext{
${ }^{84}$ GLUCK, Sherna. What's so Special about Women? Women's Oral History. In: Frontiers: A Journal of Women Studies, edição especial, vol II, 1977. p. 3-14.

${ }^{85}$ GLUCK, 1977, op. cit., p. 3.
} 
de vida e da historiografia, traz o presente, de modo a ampliar o repertório de experiências e de conhecimentos que o compõem.

\subsection{As colaboradoras}

Contamos com cinco colaboradoras, duas de nacionalidade boliviana, duas de nacionalidade paraguaia e uma de nacionalidade peruana. As entrevistas são parte do trabalho de história oral, e a sensibilidade do pesquisador deve se atentar à busca de experiências e não de informações. Aqui as entrevistas foram feitas de forma aberta, com algumas perguntas orientadoras, mas priorizando a fala livre, na tentativa de preservar o caráter genuíno do relato, da experiência e da história de vida. Levamos em conta o que Marcela Boni Evangelista ${ }^{86}$ diz:

Entendemos a entrevista enquanto um momento em que pontos de vista distintos se encontram. Trata-se de uma situação marcada pela interlocução e pela produção de significados novos, perpetrados pela ocasião em questão. Ambas as partes integrantes de tal interação têm responsabilidade sobre seus resultados e ao admitir a ausência de imparcialidade, o pesquisador assume os riscos de escrever a história de uma outra pessoa que por alguns momentos é ele mesmo.

As entrevistas foram feitas entre fevereiro de 2012 e março de 2013. Não elegemos um local específico, isso foi de acordo com a disponibilidade de cada entrevistada. As deixamos à vontade para usar o idioma natal, o espanhol, para o registro das histórias de vida. A tradução foi feita no momento de converter as transcrições em documento.

\section{Luzetânia}

A primeira história de vida é de Luzetânia Quino Flores, boliviana, 32 anos. Desconfiada, demorou para esboçar o primeiro sorriso. Sua história narra sua triste vida e todos os seus percalços e sua responsabilidade em ser o pilar de sua família. Vítima de tráfico de pessoas, nos conhecemos quando me procurou pedindo ajuda pois queria reaver a

\footnotetext{
${ }^{86}$ EVANGELISTA, Marcela Boni. A transcriação em história oral e a insuficiência da entrevista. In:
} 
foto do seu filho, até então sem nome, e seu chinelo, que sua empregadora, compatriota e vizinha de povoado se recusou a dar por ter fugido de sua oficina de costura onde trabalhava sete dias por semana, costurando e cozinhando.

O registro de sua fala foi realizado em uma praça de alimentação de um shopping na zona norte de São Paulo e durou 2 horas e 20 minutos. Baseou-se sobretudo em sua vida na Bolívia e na série de acontecimentos que a levou a migrar para o Brasil, deixando seus quatro filhos com suas irmãs, e com o objetivo de saldar uma grande dívida financeira de sua família.

Nancy

A história de vida de Nancy Pasis Perla foi registrada no Centro de Apoio ao Migrante, onde a conhecemos, e onde ela foi denunciar seu ex-patrão e compatriota, que não pagou por quase três anos de trabalho. Aventureira, veio para São Paulo sem saber o que encontraria, e acabou sendo vítima de trabalho análogo ao de escravo. Em 1 hora e 10 minutos de entrevista, ela contou sobre a sua vinda para o Brasil, impulsionada pela falta de perspectivas na Bolívia para uma adolescente, que a duras penas se tornou uma mulher decidida e cheia de atitude que não teve medo de denunciar seu patrão.

\section{Cecília}

Foi preciso marcar oito vezes para conseguir entrevistar Cecília, sendo que em uma dessas vezes ela só desmarcou duas horas depois do horário combinado. No entanto, valeu a pena. Marcamos a entrevista em sua casa, que foi precedida por uma manhã de compras no Mercado Municipal, e um delicioso almoço peruano. A conheci no Centro de Apoio ao Migrante, e depois participarmos juntas de um documentário chamado "De braços nem tão abertos". Cecília hoje vive bem no Brasil com seus três filhos, vendendo comida peruana na feira boliviana Kantuta, mas sua história envolve violência doméstica e duas mudanças de país.

\section{Maria Cristina}

Conheci Maria Cristina como "namorada do Leo", paraguaio que fazia parte de Japayke, uma associação de paraguaios a qual eu dava consultoria. Conversando com ela após uma palestra, percebi em seus olhos a vontade de lutar pelo seus compatriotas. 
Incentivada pela mãe a migrar, ela foi vítima de abusos de vários tipos por seu empregador, e hoje trabalha para que mais paraguaios tenham acesso a informação, além de batalhar para que a sua cultura não seja esquecida. Sua entrevista foi feita no cômodo em que morava, no Bom Retiro.

\section{Dora}

Conheci Dora através das assistentes sociais da escola em que um de seus filhos estuda, na divisa com Diadema. Eles estavam batalhando há três anos para que os filhos, nascidos no Paraguai, tivessem sua situação migratória regularizada. Ela foi entrevistada em sua casa, onde mora com seus três filhos e cachorro, e onde cada objeto foi doado por pessoas que se comoveram com sua história. Por quase três horas ela contou, em português, seus dez anos em São Paulo e o cotidiano como mãe de dois filhos que requerem cuidados e atenção especial.

Na tabela abaixo, um sumário sobre as cinco colaboradoras:

\begin{tabular}{|l|l|l|l|l|l|}
\hline Nome & Idade & Origem & $\begin{array}{l}\text { Com quemQuando } \\
\text { está no Brasil } \\
\text { chegou a São } \\
\text { Paulo }\end{array}$ & $\begin{array}{l}\text { Data da gravação } \\
\text { da entrevista }\end{array}$ \\
\hline $\begin{array}{l}\text { Luzetânia } \\
\text { Quino Flores }\end{array}$ & 34 & Bolívia & Sozinha & 2010 & Fevereiro/2012 \\
\hline $\begin{array}{l}\text { Nancy Pasis } 26 \\
\text { Perla }\end{array}$ & Bolívia & Sozinha & 2009 & Março/2012 \\
\hline $\begin{array}{l}\text { Cecília } \\
\text { Lumbreras }\end{array}$ & Peru & Com os 32000 & Junho/2012 \\
\hline $\begin{array}{l}\text { Maria Cristina26 } \\
\text { Romero }\end{array}$ & Paraguai & Sozinha & 2010 & Agosto/2012 \\
\hline $\begin{array}{l}\text { Dora Coronil41 } \\
\text { Palacios }\end{array}$ & Paraguai & Com os 32002 & Março/2013 \\
\hline
\end{tabular}




\section{A MIGRAÇÃO EM SUAS HISTÓRIAS}

\subsection{Dora Coronil Palacios}

\section{Fazíamos questão de falar guarani em casa}

Meu nome é Dora Coronil Palacios, tenho 39 anos, nasci em 1973, sou paraguaia e moro no Brasil há dez anos.

Tenho uma família grande, com 10 irmãos, todos moram no Paraguai. Meus pais já faleceram. Mas eles me fizeram estudar, e estudei até o ensino médio. Meu pai era agricultor, morávamos na roça. Eu não fiz faculdade, mas trabalhei numa empresa grande por cinco anos depois que eu me formei. E quando estava na escola não trabalhava, mas tinha muito trabalho na minha casa!

Morávamos em Encarnación, no interior. Eu ajudava mais a minha mãe. Meu pai tinha muita terra, plantava soja, trigo, algodão e tinha muitos animais domésticos em casa. E eu ajudava minha mãe a cuidar dos animais.

A gente aprendeu a falar guarani e espanhol, mas fazíamos questão de falar guarani em casa. Meu pai ensinou as duas línguas, e na escola era obrigatório saber as duas! Guarani foi uma das matérias mais difíceis para mim, era muito difícil na prova ter que converter do guarani para o espanhol, mas mesmo não entendendo tudo, é uma obrigação falar o guarani para os paraguaios. Eu mesma, quando encontro com minhas irmãs, minha família, a gente fala mais o guarani que o espanhol. É uma conversa mais doce e simpática.

A gente mudou para a cidade depois que meu pai faleceu. Na verdade eu já morava na cidade, eu já tinha dezesseis anos e estudava. Mas minha mãe continuava morando na roça com o meu pai. Quando ele faleceu, eu e meus irmãos a levamos para morar na cidade.

Todos os meus irmãos moravam na cidade, eu já estava estudando e trabalhando, e minha mãe foi morar comigo. Quando ela ainda morava na roça com o meu pai, nós íamos visitá-los aos domingos, mas quando o meu pai faleceu, nós não queríamos que ela ficasse sozinha, então decidimos que ela devia morar perto da gente, e ela foi morar comigo. Eu sou 
a caçula, meus irmãos já eram casados. E eu fiquei bem triste quando o meu pai morreu, então a gente fazia companhia uma para a outra.

Nesta época se eu fosse fazer faculdade, eu queria estudar medicina. Meu sonho era ser médica! Mas era muito caro, minha mãe não podia pagar os meus estudos, e eu tinha que trabalhar! O pouco que eu ganhava era para ajudar a minha mãe.

E nesta firma que eu trabalhava eu conheci o meu marido, o Gustavo. A gente namorou, casou e eu engravidei. Começamos a namorar quando eu tinha 24 anos, e depois de 2 anos, nos casamos. Quando eu tinha 27 anos eu engravidei do Arnaldo, que nasceu em 2001. Mas quando eu engravidei nós mudamos de Encarnación para Ciudad del Este.

Tinha sim a possibilidade de salvar este olho, mas não no Paraguai

E Arnaldo nasceu! Tudo normal, mas aos poucos fui percebendo que ele tinha alguma coisa no olhinho dele. Alguma coisa diferente, pois parecia que ele não enxergava do lado direito, chorava muito. Não estava normal, e quando ele fez seis meses, o olho dele ficou inteiro branco.

Já tínhamos procurado vários médicos, e nada de resultado, depois deste episódio corremos para outro especialista que nos encaminhou para a capital (Assunção) para fazer o exame, pois se suspeitava de um tumor maligno. E depois de muitos exames, o câncer foi confirmado. Começamos imediatamente o tratamento, com a quimioterapia, mas ele perdeu o olhinho.

O oncologista disse que o tumor tinha calcificado, e que precisaria fazer uma cirurgia para tirar o olho e colocar uma prótese. Mas eu quis a opinião de uma médica que eu confiava muito para ela fazer a cirurgia. Ela aceitou, mas antes pediu para fazer uma ressonância. Depois deste exame, veio a verdade: o tumor não tinha calcificado e sim passado para o outro olho!

Não sei se o oncologista mentiu, ou era incompetente, mas a verdade era essa. O tumor já tinha tomado conta do olho inteiro, do globo ocular já tinha passado para o outro olho. A Dra. Carmem fez a cirurgia e não só retirou o olho, mas também o globo ocular, porque o câncer já tinha avançado. Mas ela disse que para prosseguir este tratamento, e 
conseguir salvar o outro olhinho, eu deveria continuá-lo no Brasil ou Argentina, pois eles não tinham condições de fazer isso lá.

Ela falou que poderia entrar em contato com colegas no Brasil, porque a gente tinha que ter uma ideia de quanto seria este tratamento, e se realmente tinha chances de dar certo. Ela nos retornou dizendo que tinha sim a possibilidade de salvar este olho, mas não no Paraguai, porque lá se fossem fazer radioterapia, ele ia ficar cego, porque não tem proteção para a visão o que poderia queimar o tumor e também a visão.

E ela ainda falou que o valor para fazer este tratamento era muito alto, muito alto mesmo, e a gente não tinha este dinheiro, nem poupança, nem casa para vender. E nem se tivesse! Eu não lembro a quantia exata, mas eram milhões! Foi um desespero muito grande, querer salvar a vida do seu filho e não ter o valor que pediam. Eu chorava o dia todo. Ainda mais porque eu ia ao hospital todos os dias para trocar o curativo do Arnaldo e a médica ficava perguntando se eu já tinha conseguido uma forma de ir para o Brasil... Ai, que desespero!

Mais desespero foi quando os médicos falaram que o tempo que teríamos que ficar no Brasil era indeterminado. Eu achava que eram uns quinze dias, que este tempo seria suficiente, mas não, a médica falou que ele tinha que passar por um tratamento de radioterapia para queimar o tumor que estava atrás da visão, e por ser um tumor que cresce muito rápido, não podia ficar muito tempo sem o tratamento.

Foi aí que tive a ideia de pedir ajuda em um programa da televisão, em Assunção, no canal 13. Depois de uma noite de desespero, na qual eu chorei, chorei e chorei, ao vê-lo dormindo, eu conversei com Deus, pois Ele era a minha esperança, eu não tinha mais nada. E pedi para Ele um sinal sobre o que fazer. Falei: "se o Arnaldo tiver uma possibilidade, nem que seja bem pequena, de salvar este olho, que Deus me dê um sinal sobre o que fazer". Pois eu não tinha o dinheiro que eles estavam pedindo, mas eu queria um sinal, só isso que eu queria, um sinal Dele.

E no dia seguinte fui ai hospital para fazer o curativo, e encontrei um homem sentado lendo o jornal. Eu olhei para ele, ele olhou para mim e disse: "o que aconteceu, o seu filho operou?”. E eu respondi que sim. E ele continuou perguntando: “o que ele tinha, catarata?”. E eu contei que ele tinha câncer. E continuei: "mas isso não é nada! O mais grave é que o 
outro olho dele também está comprometido, e eu preciso salvar este olho! E preciso de milhões de guaranis, e eu não tenho". E caí no choro.

E o homem me consolou, disse para eu não chorar e sugeriu: "porque você não vai para o canal 13 ? Pede ajuda que você vai conseguir".

Foi o sinal de Deus que eu pedi na noite anterior. Minha fé é esta! Pedi um sinal para Deus, e Ele me mandou! Cheguei na casa da minha irmã, que mora em Assunção e perguntei se ela sabia onde era o canal 13. Ela respondeu: “eu sei, por quê?”. Respondi: "quero ir lá". Ela me explicou onde era, e eu nem almocei, fui para lá, com ela, o Arnaldo e um relatório médico. Quando eu ia entrar no canal, parou o carro da apresentadora do programa da manhã. Ela viu o meu filho e falou que ele era bonitinho. E minha irmã começou a chorar de emoção, porque ela era fã da apresentadora, que era tipo uma Ana Maria Braga de lá, só que mais jovem, mas que também ensinava receitas culinárias.

Aí aproveitamos e expliquei que o meu filho tinha uma doença, e dei o relatório médico para ela ler. E ela leu e começou a chorar, e falou que era para a gente ir na emissora no dia seguinte bem cedo que ela ia colocar o meu caso no programa dela. Aí eu amanheci no canal! Ela pediu para chegar às $7 \mathrm{~h}$ da manhã e eu cheguei bem antes disso, nem dormi!

Fizemos a entrevista, filmou o Arnaldo, meu marido não pôde ir, porque são cinco horas de viagem da Ciudad del Este a Assunção. Só eu quem falei. Contei a história do Arnaldo, ela me perguntou o que eu precisava. E eu falei, não foi fácil enfrentar a câmera para falar, mas eu pensei "Deus, eu vou fazer de tudo, roubar eu não vou, mas o resto eu faço!”. Falei que se cada um pudesse contribuir com um pouco que fosse já me ajudaria. Me segurei para não chorar! E disse que a única chance de salvar meu filho custava milhões de guaranis. Mas falei que estava lá porque eu não ia ficar de braços cruzados deixando o meu filho morrer. A apresentadora falou que quem quisesse contribuir poderia depositar o dinheiro em uma conta que eles tinham aberto para isso.

Só que para a minha surpresa eles começaram a anunciar nos jornais do meio-dia e da noite, e ainda continuaram a passar neste programa. E o povo começou a fazer fila no banco para depositar o dinheiro para ajudar o Arnaldo! Foi muito bom!

Eu sentia que estava sendo abençoada, sentia que era um milagre de Deus! E vi que a fé realmente move montanhas! Eu falava “eu não tenho dinheiro, mas eu tenho um Deus que 
não se compara com todo o dinheiro do mundo", e Deus foi abrindo as portas para mim! E quando eu estava quase chegando na quantidade necessária, recebi uma ligação do consulado do Brasil, pois a apresentadora de TV fez uma carta para o consulado contando o meu caso e pedindo ajuda. Pediu também para a primeira dama do Paraguai, que me deu a passagem de avião.

De certa forma eu mobilizei o país, como um milagre! Porque muita gente pede ajuda, mas não é todo mundo que recebe, inclusive nestes programas de auditório. Mas o Arnaldo é muito especial, e a minha fé não é pequena! Confiei a Deus a minha única solução, e Ele tocou no coração de todo mundo, e continua tocando!

E quando ligaram no Consulado, perguntaram se eu podia viajar naquele dia mesmo ao Brasil. E falaram: "se a senhora quiser viajar hoje, a senhora terá o melhor hospital de câncer gratuito para o seu filho". Aquilo foi pura emoção! O dinheiro que eu tinha ganhado eu poderia pagar as minhas despesas no Brasil com aluguel, comida, para ter como eu me manter.

Não acreditei quando ouvi que eu ia ter o hospital de graça! Deus me atendeu! Eu ainda não tinha todo o dinheiro, e Ele sabia que não iam ser quinze dias no Brasil, na verdade já são mais de 10 anos de tratamento! Mas assim a minha vida estava encaminhada com aquele dinheiro. E não sabia falar uma palavra de português. O meu marido, Gustavo, sabe, mas ele vinha em outro voo. Na verdade esta passagem ele ganhou de uma pessoa que ligou na TV e disse que ia dar, já que eu falei que ele ia vir de ônibus. Ele queria vir antes para me esperar, porque eu estava morrendo de medo por não saber o português, e o Gustavo nasceu na fronteira, então sabia falar a língua.

Nós nos conhecemos na minha cidade, ele foi prestar um serviço na firma que eu trabalhava. Ele cadastrava as pessoas que queriam um telefone, porque naquele época não tinha tantas tecnologias como hoje, e para comprar o celular, aqueles tijolos, tinham que se inscrever, e eu queria um celular. Nossa agora só de pensar, os celulares era muitos pesados! A gente colocava na bolsa e o braço caía (risadas). Ah, e tinha que levantar a anteninha para falar. E eu comprei um destes.

E como o Gustavo era amigo de uma amiga, ela falou: "Dora, vem um amigo da Ciudad del Este para fazer ativação do celular de graça, na promoção". Aí ele ativou o meu, 
a gente se conheceu e aí começou tudo! O tijolo nos uniu (risadas).

Voltando a minha chegada ao Brasil. Viemos em voos separados, o meu voo era da TAM, e saiu primeiro, só que o dele chegou primeiro, pois o meu fez escala em Foz do Iguaçu, e o dele era direto. E ele chegou no aeroporto e começou a me procurar. E quando cheguei não encontrava com ele, e foi me dando um medo, parecia que eu estava na Europa! Era um lugar muito grande e diferente o aeroporto de Guarulhos. E a comissária falou para eu ficar sentada com o meu filho que ele ia me achar. E lá fiquei eu, meia hora esperando, com medo, já chorando.... Depois o encontrei e foi um alívio, a gente pegou um táxi porque queríamos ficar hospedados perto da GRAACC, ${ }^{87}$ na Rua Botucatu, perto do metrô Santa Cruz. E o taxista nos deixou num hotel bem econômico, mas mesmo assim achamos tudo tão caro! Só o táxi, tinha dado $\mathrm{R} \$ 100,00$ ! No dia seguinte fomos até a GRAACC, e estavam todos nos esperando, e o atendimento ao Arnaldo foi muito bom!

E os exames foram feitos em caráter de emergência, porque precisava detectar se tinha câncer em outro lugar no corpo. E quando eu ficava ouvindo a conversa do Gustavo e dos médicos eu parecia uma galinha, ou um pintinho atrás da galinha ou do galo! Eu só andava atrás do Gustavo, porque eu não entendi a conversa, não conseguia prestar atenção. E ele me levava para todos os lugares, me ensinava a andar de metrô, mas eu não prestava atenção, porque ele estava comigo. Até que um dia eu chorei e briguei com ele, porque a gente entrou para almoçar em uma lanchonete, e ele me deu o dinheiro e falou: "vai lá pagar". E eu falei: "não vou, vai você". E ele insistiu: "vai você para aprender". E eu comecei a chorar, eu não queria pagar, eu não sabia pagar, não sabia quanto que ia ser o troco, não entendia a moeda brasileira. Ele não fazia isso por maldade, mas ele queria que eu fosse treinando, porque eu ia ficar sozinha aqui com o Arnaldo, e ele queria que eu estivesse preparada.

Ele ficou quinze dias comigo. Só do hotel que nós dormíamos pagávamos $\mathrm{R} \$ 30,00$ por dia, a roupa tinha que mandar lavar. Uma vez ele pegou umas camisas dele, umas roupinhas do Arnaldo e foi mandar lavar. Quando ele voltou, disse que para lavar este pouco de roupa eram $\mathrm{R} \$ 80,00$ ! Nossa, queria que ele fosse lá pegar as roupas de volta! E ele foi, e pedi para ele comprar um ferro pra mim, porque eu podia lavar as roupas na pia do banheiro, e pendurava nas cadeiras, na sacada do hotel. Foi uma forma de economizarmos, porque ainda tínhamos que pagar para comer! As roupas demoravam para secar, porque São Paulo 
estava muito frio, e garoava bastante, não tinha sol.

A gente já sabia que não seriam só os quinze dias, o tratamento era por tempo indeterminado, sem dia nem hora para acabar. Então, antes do Gustavo ir embora, fomos procurar um lugar mais barato para ficar, alugar alguma coisa. Perto do hospital era impossível, não tinha lugar, e o que tinha era mil, dois mil reais, ou se fosse só para alugar um quarto, tinham mais 10 pessoas no mesmo quarto, e eu não sabia falar o português, impossível morar num quarto com tanta gente desconhecida e o meu bebê.

E olha como são as coincidências, o Gustavo precisava voltar ao Paraguai, e nós não encontrávamos um lugar para eu ficar. Em seu último dia, Gustavo foi a lanchonete comprar comida com o Arnaldo, e voltou todo feliz. Disse: "Dora, achei um lugar para você morar". E eu comecei a chorar, porque se ele achou um lugar para EU ficar, quer dizer que ele tinha que ir embora. E ele falou que o dono da lanchonete tem uma casa, que ele aluga quartos, e tem um disponível. E ainda falou que quando eu quisesse ir ao hospital, ele poderia me levar até a lanchonete, que é bem pertinho de lá, mas se eu quisesse, tinha uma lotação que passava na frente da casa dele e que ia ao hospital São Paulo. Obra de Deus!

E a gente foi visitar a casa. A mulher do dono da lanchonete era uma pessoa muito boa, tem dois filhos, uma já maior de idade, e ela montou o meu quarto, com fogão, panela, cama... eu só comprei o lençol. Era um quarto pequeno, em que cabiam duas camas de solteiro, tinha banheiro e cozinha. O aluguel era $\mathrm{R} \$ 500,00$, fora a água e a luz. Se hoje é caro, imagina há dez anos atrás!

\section{No entiendo!}

Quando o Gustavo foi embora, parecia que eu tinha enterrado alguém, eu chorei muito! Fiquei com medo de ficar sozinha, não conhecia ninguém, não sabia falar, a comida é diferente, eu não sabia fazer compras, não sabia o nome das frutas, dos legumes, porque o espanhol é parecido com o português, mas muitos nomes mudam.

Mas antes de ir ele me falou: "Dora, presta muita atenção quando as pessoas forem conversar com você. Assim prestando atenção você vai aprender a falar!”. E eu chorava, “como eu vou pegar o metrô?”, era um medo terrível, foi muito difícil, chorei, chorei e 
chorei. No meu primeiro dia sozinha, o dono da casa nos levou ao hospital. Cheguei lá, e nem bom dia eu sabia falar! Levantava a mão, e eles já sabiam que eu não sabia falar. A médica me chamou, falou que o Arnaldo tinha que fazer um exame. Ela tinha que me levar para outro prédio, e foi conversando comigo, eu não entendia nada! Lembro que ela me perguntou onde eu morava, eu não entendi aí ela falou: “Sua habita aonde?” E eu pensei "habita é o lugar de morar" e eu respondi "Paraguai!". Ela me deixou no prédio, conversou com a enfermeira, com o médico, e fiquei lá, só que ela não avisou que eu não entendia nada! E o médico começou a falar comigo, e eu não entendia nada mesmo, porque ele era gago! (risadas). Imagina, gago e em português (risadas). Nesse momento eu chorei tanto que agora parece piada e o médico falando para eu trocar a fralda do meu filho, e eu olhando para a janela, chorando... e ele me cutucou nas costas e falou de novo, eu virei, e ele me viu chorando! A única coisa que falei foi: "No entiendo!"

E ele chamou a enfermeira, que pegou o Arnaldo, o deitou e falou: "trocar fralda", e começou a tirar a fralda. E em espanhol fralda é pañal, não é uma palavra parecida! Saí de lá e queria voltar, queria ir embora, eu chorava vinte quatro horas! Mas aí pensei comigo mesmo, "não foi eu quem implorei para Deus, eu não chorei para Deus para chegar até aqui, e agora estou chorando para voltar?". E eu me autoconsolava.

E aos poucos fui aprendendo, pegava a perua para ir ao hospital, a dona da casa escreveu em um papel o endereço que eu tinha que descer e onde eu ia descer quando voltasse. Até que eu peguei a lotação sozinha, meu coração na boca! E comecei a prestar atenção nas pessoas, como o Gustavo me falou. E vi que as pessoas antes de descer diziam “Próxima desce!". O cobrador perguntava onde eu ia descer e eu fazia de louca e fingia que eu não ouvia, para não morrer de vergonha. Quando voltei para casa, fiquei ensaiando em frente ao espelho a falar "Próxima desce!" (risadas). E comecei a por em prática! Quando voltava do hospital eu tinha que dizer: "na rua da Padaria Assembleia desce", só que não conseguia dizer esta palavra. Eu falava panaderia Assembleia, e o cobrador não me entedia, perguntava o que eu estava falando, e eu não respondia. Pedi para escreverem em um papel "padaria Assembleia", e mostrava para o cobrador. Tinha gente que me xingava, dizia que não entendia nada, mas tinha gente muito educada, que queria ajudar a atravessar a rua, pois às vezes eu ficava com medo de atravessar com o meu filho, e as pessoas se ofereciam para me ajudar e eu não entendia nada, e não respondia. Com certeza devia ter gente que pensava que eu devia ser louca, ou metida, mas como eu ia responder, se eu não entendia? Mas valeu 
a pena, o Arnaldo fez um tratamento muito melhor, e eu fui muito bem tratada no Brasil.

Voltando ao tratamento, aconteceu algo que me deixou bem chateada. A médica do Paraguai disse que tinha que fazer radioterapia. Mas aqui no Brasil, eles falaram que não era assim, que tinha que primeiro fazer os exames, e depois que foram feitos, eles falaram que ele tinha que fazer quimioterapia, e aí se não adiantasse, fariam a radioterapia. Achei super estranho, pois ele tinha feito a quimio no Paraguai, e a doutora do Paraguai tinha mandado a biopsia do olhinho dele, e o médico do GRAACC não tinha acreditado, porque o tumor não tinha calcificado. Falei para ele que ele tinha feito quimio do seu sexto mês de vida até o seu primeiro aniversário! E ele disse que infelizmente parecia que nunca tinha feito a quimio! Devem ter usado soro, ao invés de remédio! Que raiva, pois na primeira sessão de quimio no GRAACC o tumor calcificou! E ele fez mais quatro sessões, nem precisou fazer até a sexta sessão, e o tumor secou! Parece que Deus ajudou os médicos curarem ele!

"Nossa, Dora, que fé é essa?"

E a dona da casa me deu uma televisão! Eu assistia, mas não entendia nada (risadas). Teve um final de semana, que os donos da casa foram para a casa deles em Santos e me deixaram a chave da casa, para que eu pudesse usar a geladeira, já que eu não tinha uma. Isso foi muito admirável para mim, ela confiar em mim, deixar a chave da casa dela. Foi o máximo! No Paraguai se a pessoa não te conhece direito ela não te dá a chave de casa! Isso foi inesquecível, a confiança que ela teve comigo. Mas eu fiz por merecer, sou de confiança! Só abria a cozinha e usava a geladeira, nunca subi para o quarto. Hoje são como minha família, os conheço há dez anos.

E neste final de semana, que eles foram viajar, eu vi a missa na TV. Não entendia um capítulo do que o padre falava. Mas eu me emocionava com ele falando, me arrepiava, uma emoção inexplicável. Coloquei na minha cabeça que eu queria chegar até ele, que aquele homem precisava conhecer o meu filho e tocá-lo. Eu sentia que ele tinha que tinha que conhecer o Arnaldo. O padre, era o padre Marcelo. O próprio! Só que na época eu nunca tinha ouvido falar nele.

Quando voltaram, eu peguei o dicionário espanhol/português que ela tinha me dado 
para a gente conversar. A dona da casa era boa demais para mim, pena que ela já morreu, ela foi uma pessoa muito abençoada que Deus colocou no meu caminho, todo dia de manhã me chamava para tomar café com ela. Mas ela me chamou, e perguntou se eu não tinha visto o bilhete que ela tinha me deixado, e na verdade eu vi, mas como não sabia ler português, não dei atenção. E ela perguntou: "Dora, você não viu o bilhete aqui?". E eu respondi que sim, e ela falou: “poxa você não colocou o lixo pra fora!” E eu perguntei: “o que que é lixo?” E ela começou a rir! E explicou que sábado passa o lixeiro, que era para colocar o lixo para fora. E o lixo apodreceu. E eu falei que no Paraguai lixo é basura, e ela entendeu vassoura!

Tinha estas confusões! O nome dela é Marina, e uma vez apareceu uma barata no meu quarto, e eu tenho nojo de barata, e falei para ela: "Marina, Marina, tem uma cucaracha no meu quarto!” E ela não me entendia. Subiu lá no meu quarto e disse: “É uma barata!”. E assim fui aprendendo que cucaracha era barata!

Bom, mas peguei o dicionário e falei: "Marina, vi a missa na $\mathrm{TV}$, eu quero ir na missa". E ela me perguntou qual missa, e eu falei a hora do programa, e ela falou que era a missa do Padre Marcelo. E perguntou se eu queria que ela me levasse lá, e eu respondi que sim, e combinamos de ir no domingo próximo.

E foi ótimo, porque eu queria tanto ir lá, mas não saberia como chegar, não chegava nem na esquina, imagina chegar até a zona sul de São Paulo. E ela me levou. Fomos de ônibus, e uns quatro quarteirões antes de chegar eu já ouvia as músicas e ficava emocionada, chorava, uma emoção inexplicável. Deus sabe o que eu senti. Da primeira vez não consegui falar com ele, na segunda também não, mas na terceira disse que não passava, que tinha que ser aquele dia. E a Marina me apoiou nessa empreitada, ela é muito católica e no quarto dela ela tinha uma foto do padre Marcelo ao lado de Jesus!

Mas ela me dava uns conselhos, dizendo que ia ser muito difícil falar com ele, que ela morava há tantos anos em São Paulo e nunca tinha conseguido falar com ele nem por telefone. Mas eu insisti, disse que eu ia conseguir, porque eu sempre fui uma mulher positiva, eu nunca falei que não poderia, sempre penso que posso, que vou conseguir e até agora sou assim, graças a Deus sempre deu certo. E a Marina até riu e falou: "Nossa, Dora, que fé é essa?". E eu falei: "você vai ver Marina, vai ser hoje!". E pedi para a filha dela fazer um cartaz para mim, dizendo que eu sou do Paraguai, que tenho um filho com câncer e que quero falar com ele. 
E ela fez! Tem uma missa de noite também, e eu ia nessa missa. Ao sair de casa, o carro da filha da Marina não pegava. Pensei, "será que é um impedimento?” e o pai dela falou: "Vocês são doidas, sair de noite com criança", e ela falou que eu tinha uma missão! E ele emprestou o carro dele.

Chegando na missa, eu estava sentindo uma grande emoção, e só chorava, chorava, era muita gente. Mas consegui ficar bem perto dele, com o Arnaldo no meu colo e a filha da Marina segurando o cartaz. E ficou mostrando para ele, e eis quando acabou a missa, ele viu o cartaz e disse "Deus te abençoe, mãe", e mostrou uma porta para mim. O voluntário viu, e me guiou até a porta. Claro que eu comecei a chorar! Mas desta vez a Marina e a filha dela também choraram.

Chegando lá, havia uma fila enorme, cheio de mãe com criança com câncer. E teve uma vez que o Arnaldo tinha mais ou menos um ano e meio, estava brincando na casa da Marina, perto de uma escada, e ele falou para ela: vem brincar comigo, vem. Fiquei arrepiada, porque fui olhar e não tinha ninguém lá, mas ele continuava chamando. Quando chegamos perto do Padre Marcelo ele falou: "mãe, é o Jesus que vi na escada, é o Jesus que vi na escada. Mãe, é o Jesus!” E o padre Marcelo foi chegando mais perto, e rindo, e o Arnaldo continuava: "Mãe, é o Jesus", e quanto mais ele aproximava, parecia que a mão não era dele, para mim era o próprio Jesus, com a mão mais linda que eu já vi. Parecia que saía uma luz dela. E ele ia chegando mais perto e o Arnaldo repetia: "Mãe, é o Jesus”, e eu só chorando, quando ele colocou a mão na minha cabeça eu não consegui mais segurar o Arnaldo, e um voluntário o pegou.

E ele falou em espanhol comigo, e perguntou se eu era a mãe do menino, e eu respondi que sim. Ele perguntou se eu acreditava em Deus, e eu respondi que acreditava, ainda mais depois de tudo o que estava acontecendo na minha vida, contei. Disse ainda que graças a minha fé estava lá. E ele me disse: "Se a senhora acreditar, Deus vai dar uma resposta para a senhora”, e fez uma oração.

Isso foi numa quinta-feira, e o Arnaldo já tinha começado a quimio. Na segunda seguinte, ele tinha que fazer o exame de fundo de olho, para ver se a quimio tinha calcificado o tumor. E não é que o médico saiu do centro cirúrgico sorrindo, e me falando que o tumor tinha calcificado? Eu gritei: "Deus curou meu filho!!”. E o doutor respondeu: "É, eu acredito". 
E hoje, dez anos que o tumor secou, ele nunca mais voltou! Sinto que naquele dia que fui na missa do Padre Marcelo, Deus me mandou uma resposta. E Ele fez tanto por mim, abriu as portas, me deu dinheiro para sobreviver aqui, e o melhor presente, curou o meu filho.

Ele ainda é acompanhado pelo GRAACC, faz fundo de olho e ressonância regularmente, mas até agora o tumor permaneceu seco. E eu conto feliz esta história para muita gente! Preciso um dia contar para o próprio Padre Marcelo!!

\section{Milagros}

Depois de ter saído do Paraguai, sempre voltava, para as festas de fim de ano, o Natal, Ano Novo, mas em janeiro volto para São Paulo, pois o tratamento é contínuo. Mas no ano de 2003 eu fui ao Paraguai em junho. Fiquei grávida de novo, e não iria ter condições de ter o meu filho sozinha no Brasil. No dia seguinte que o Arnaldo fez dois anos, em 21 de julho, nasceu o Alan em 22 de julho. Inclusive quando fui visitar o Padre Marcelo, o Alan tinha três meses!

Ele era um bebezão, nasceu com quatro quilos. Acho que era muito grande e não tinha espaço para ele dentro da minha barriga! Então comecei as contrações mais cedo que o normal, mas tomei remédio para segurar ele lá dentro. Quando ele tinha dois meses voltei para o Brasil, e a luta foi maior ainda. Bebê no colo, Arnaldo com dois anos... não foi uma gravidez programada, mas Deus mandou e recebi.

Toda vez que eu ia para o Paraguai eu voltava grávida! Porque depois eu engravidei da Milagros! Só que ao contrário do Alan, o pré-natal dela eu fiz no Paraguai. A diferença de idade entre eles é bem pequena: dois anos entre o Arnaldo e o Alan, e dois anos e três meses entre a Mila e o Alan

Mas eu fiz o pré-natal da Mila lá, porque foi uma gravidez de risco. Durante a gestação eu fiquei sabendo que a Mila tinha uma doença nos ossos. Os médicos falaram que ou ela ia ser muito baixinha ou ela ia ter a doença que ela tem, pois o comprimento dos ossos não era normal. Mas eu não fiquei sabendo desde o começo. Eles só falaram quase no final. E eu já estava no Paraguai. Se eu tivesse feito o pré-natal aqui no Brasil, talvez tenha 
sido diferente, talvez eu ficasse sabendo antes. Mas com o tumor do Arnaldo tinha secado, a gente só vinha ao Brasil umas duas vezes por ano, só para acompanhar.

Quando a Mila nasceu, os médicos falaram que ela só ia viver por três dias. Mas a minha fé em Deus aumenta todo dia, e eu que pedi tanto ter uma menina, ela veio. Quando os médicos falaram: "ela era uma bomba de tempo, só vai viver três dias". E eu pensei: "Deus, eu pedi uma menina, e o Senhor me deu, agora entrego a minha filha nas tuas mãos e se ela sobreviver ela vai ser um milagre". Por isso o nome dela é Milagros, que quer dizer Milagre em português. E já está com sete anos!

Para o tratamento dela, tive que voltar ao Brasil. Já sabia o caminho e consegui tudo! A assistência social do GRAACC encaminhou para o hospital Lar São Francisco, que é do próprio hospital São Paulo. Eu já estava um pouco melhor no português! Pelo menos já sabia o que era "fralda" (risadas).

Hoje ela está bem melhor, ela nasceu toda mole, cabeça, osso... a cabeça parecia uma bexiga, eu a carregava no travesseiro, não podia pegá-la como uma criança normal, não podia trocar a fralda como uma criança normal. Todo o cuidado era pouco com ela, tinha sempre que tomar muito cuidado.

E a parte financeira sempre foi muito complicada. O dinheiro que eu ganhei da TV durou uns três meses, porque o aluguel era muito caro. E era uma burocracia para receber este dinheiro, pois eu não trouxe todo ele, e acabei deixando na conta de meu cunhado, que morava na capital, e ele me mandava, quando eu precisava. Só que eu tinha que ir no centro de São Paulo, no Banco do Brasil da Rua São Bento. Ainda bem que o Gustavo me ensinou como chegar. A gente ia de metrô para eu aprender, mas eu não prestava atenção. Quando chegou o dia que eu tive que ir sozinha na Rua São Bento, fui com o endereço em um papelzinho e ia mostrando para todo mundo. Claro que eu me perdia! (risadas) E o Arnaldo do meu lado! Mas eu não fui tão burra, pelo menos eu não mostrava o papelzinho para qualquer um, sempre perguntava para o segurança!

No banco eu tinha que esperar muito, e saía de lá com mil reais. Pagava o meu aluguel e o resto servia para eu comprar minhas coisinhas, não gastava muito em comida porque o Arnaldo tinha um aninho, e eu descobri o que era sacolão! Era engraçado, pois eu não sabia falar o nome das coisas, mas o bom é que lá eu via as frutas e os legumes! Banana 
é banana pelo menos, mas alface é lechuga, cenoura é zanahoria, abóbora é zapallo, laranja é naranja, que é parecido, mas imagina pedir aqui naranja! Ninguém sabe o que é naranja (risadas). Algumas coisas só mudam as letras, mas confunde!

\section{A luta diária é muito grande, e eu não sou mulher de reclamar}

Depois que nasceu o Alan, o meu marido que mandava dinheiro, pois tinha que pagar o aluguel. Mas tive que mudar de casa e procurar um aluguel mais baratinho. Quando a Milagros nasceu ele continuava mandando dinheiro, mas é complicado para ele. Mas mesmo assim ele conseguia me mandar uns $\mathrm{R} \$ 200,00$ por semana. Agora, depois de dez anos, as coisas mudaram. Ele mudou de serviço, agora é vendedor de carro, e às vezes ele não vende nada, não tem um salário fixo. Se vende tem comissão, se não vende não ganha nada.

As coisas mudaram tanto entre a gente, que depois destes 10 anos, eu nem me considero mais casada. A gente se dá bem, somos mais amigos mesmo. Eu abri mão da minha vida pelos meus filhos, e ele está lá, não quer morar aqui. Quer dizer, agora ele até cogita morar aqui, mas eu estou tranquila. A luta diária é muito grande, e eu não sou mulher de reclamar. Aliás, no fim eu sou uma mulher muito privilegiada, meus filhos são maravilhosos e Deus também colocou muitos anjos no meu caminho, tenho ajuda de muitas pessoas.

E quando ele me parou de mandar dinheiro, tive que sair para trabalhar, e como a Mila é cadeirante, eu não posso trabalhar em qualquer lugar, pois tenho que levá-la comigo. Fora que é difícil eu ter uma rotina, pois muitas vezes tenho que levar o Arnaldo no hospital, estas coisas. Há três anos o Gustavo me manda dinheiro uma vez por mês, e não dá para contar com isso, pois são $\mathrm{R} \$ 200,00$ ! O que se faz com $\mathrm{R} \$ 200,00$ em trinta dias? No supermercado tenho que comprar uma caixa de leite, a Mila tem que usar fralda... aí já foi $\mathrm{R} \$ 100,00$. As carnes são caras, compro um pedaço de bife, mais carne moída, já se vai uns $\mathrm{R} \$ 52,00$. Tenho três crianças em casa, o Arnaldo com onze, o Alan com nove e a Milagros com sete... Então tenho que fazer os meus bicos, e é só bico que eu posso fazer mesmo, não posso ser registrada, nem trabalhar todos os dias. A escola são três horários diferentes, Mila vai às sete horas da manhã, o Arnaldo vai às $13 \mathrm{~h}$ e o Alan entra às $15 \mathrm{~h}$. Com esta correria escola e hospital, como vou arrumar um serviço para trabalhar todo dia? Minha filha 
depende de mim, é cadeirante, tem mil consultas com vários tipos de médicos, fisioterapia....

A doença dela é muito grave, chama-se osteogênese imperfeita, que é mais conhecido como ossos de vidro. Ela depende 100\% de mim, e sempre vai depender de alguém! Ela não anda, não fica em pé, às vezes ela quebra algum osso, e quando isso acontece é bem difícil! Então toda semana tenho que ia ao hospital, passar com o ortopedista, e também com o pediatra.

\section{Levei quase três anos para dar entrada ao pedido de registro. Uma burocracia só.}

Aí, eu passo roupa, limpo apartamentos, mas não todo dia. Eu sempre tenho que ter dinheiro, tenho que comprar leite, pão, comida, Danoninho. Eu posso ficar sem comer, aliás, já fiquei várias vezes, mas as crianças não esperam, então tenho que me sacrificar, trabalhar. Tenho que fazer este sacrifício, mas falo sacrifício porque minha filha tem que ir junto comigo, ela sai da escola às 10h50, eu a pego e levo junto comigo.

A sorte é que agora eu não pago mais passagem. Depois que eu fiz o RNE, que demorou três anos para sair, consegui fazer a carteirinha da Mila para pegar o ônibus gratuito em São Paulo e Diadema. Mas o do Arnaldo eu só consegui fazer o de Diadema, não o de São Paulo. Então ainda tenho que fazer algumas combinações com as carteiras, pois moramos em Diadema, as escolas são em Diadema, mas todos os tratamentos são em São Paulo, e a carteirinha da direito de passe livre para o paciente e a acompanhante. É um benefício das prefeituras, mas antes de fazer o documento de estrangeiro eu não conseguia ter esta carteirinha.

Os nossos documentos no Brasil demoraram muito para ficar prontos. Demoraram, e foi muito difícil. Como todo ano eu saía do país, recebi uma permissão de três meses para ficar aqui, como turista, mas eu não faço turismo! Vim para fazer um tratamento. O que acontece é que ninguém do consulado do meu país falou que quando vencia a minha estada no país eu tinha que renovar. E na fronteira, quando eu voltava e passava pela fronteira, os policiais perguntavam porque eu estava saindo em um ano de estadia, eu dizia que estava acompanhando o tratamento médico dos meus filhos, mostrava a carteirinha e dava tudo certo. E também era só ver a Mila que eles já entendiam. Mas não era assim tão fácil. Uma vez o policial federal disse que eu teria que pagar a multa de $\mathrm{R} \$ 827,00$ para cada um! Ele 
perguntou seu eu tinha como provar sobre o tratamento. "Claro" respondi, e ele me deu cinco dias para me defender. E mesmo sem me dar nenhum papel, eu voltei para Foz de Iguaçu com a justificativa. Passei pelo mesmo policial e fui sincera, e disse que eu tinha quatro multas e precisava me defender. E ele disse: a senhora não entra mais no Brasil se não pagar esta multa, e não queria me deixar entrar para me defender. E eu fiquei muito chateada, de onde eu ia tirar quase $\mathrm{R} \$ 3500,00$ para continuar o tratamento dos meus filhos!? E falei para ele: "Puxa vida, eu não sou traficante, eu não sou assaltante, eu não sou bandida, eu não sou assassina, eu tenho um causa justa, e vim para me defender".

Eis que o médico me mandou uma mensagem que a cirurgia do Arnaldo que esperei dez anos, a cirurgia que abria a cabeça dele, para fazer uma plástica para poder colocar uma prótese na cavidade do olho que havia fechado, ia ser marcada! A cirurgia que esperei por dez anos!

E eu não podia entrar no Brasil porque tinha que pagar esta maldita multa. Mas eu não podia perder esta cirurgia! Então fiz uma coisa ilegal, contratei um motoboy, e falei: “Ô, você me faz passar de capacete, que ninguém controla moto" E então, subi na moto, passei a ponte, cheguei na polícia federal e procurei o delegado. E me informaram que o delegado tinha ido embora, e só voltava no dia seguinte. E eu voltei no outro dia, escondida pelo capacete de novo. Eu não queria ter feito isso, mas eles me obrigaram, pois não havia outra forma! Pedi para falar com o delegado, falei que era uma emergência, e contei toda a história para ele.

Mostrei um monte de cartão: do Hospital São Paulo, da GRAACC, do Hospital Santa Cruz, e falei que eu tinha multas mas que precisava entrar no Brasil, para dar continuidade ao tratamento dos meus filhos... Ele viu no computador que eu já morava há muito tempo, que eu tinha entrado em 2001, que eu saio todo o ano... ele viu a minha história toda.

Falei que nunca fui informada sobre o que devia fazer, que devia renovar meus documentos. E falei que se eu soubesse eu não teria feito isso, não ia arriscar toda uma vida de tratamento se eu soubesse que eu ia ser multada, já que não tinha como pagar essa multa, e que não podia perder a cirurgia do meu filho, que estava marcada para 20 de janeiro de $2010 \ldots$ E dei o telefone do cirurgião, o número do hospital. E repeti que não era traficante, nem bandida, nem isso ou aquilo que minha causa era justa... E falei: "eu quero que o senhor 
me dê a permissão para entrar no Brasil".

E ele me contou sobre o acordo de livre residência do MERCOSUL, ele falou que eu deveria fazer o registro temporário. E ele me autorizou a entrar, com o compromisso que eu desse a entrada para a nossa regularização migratória.

Mas pela burocracia, eu levei quase três anos para dar entrada ao pedido de registro. Uma burocracia só. Todo o documento que eu levava, os policiais da Polícia Federal da Lapa diziam que faltava algum outro. E alguns documentos venciam. E tinha a taxa que para nós quatro dava mais ou menos $\mathrm{R} \$ 750,00$. $\mathrm{E}$ eu juntava o dinheiro, faltava um documento. $\mathrm{E}$ gastava o dinheiro, eu precisava, não tinha o que fazer. Juntava o documento, quando chegava faltava outro documento. Depois que juntei tudo o que pediam, falaram que eu tinha que ter a autorização judicial do meu marido, a guarda dos meus filhos. A burocracia só aumentou, assim como a briga, pois o Juiz do Paraguai ouviu o Gustavo que disse que não tem razão de dar a guarda para a mãe, se o pai está bem de saúde, colaborando com o sustento. Acho que no fim ele tinha medo de eu ir com as crianças para a Espanha. É bem capaz que eu iria com as três crianças para a Espanha! (ironia) Ah! E como se ele nos sustentasse...

A minha sorte foi que na escola da Mila, se alguma criança é especial, as assistentes sociais vem conhecer a casa. E quando a Luci e a Joice foram em casa, pude contar toda a minha história. Elas perguntaram se eu era naturalizada, e eu disse que nem o registro temporário eu poderia fazer. E elas se comprometeram a me ajudar. E, nossa, estas anjas me ajudaram muito, pois depois que consegui o meu RNE pude me inscrever para ganhar alguns benefícios. E eu não sabia que tinha o benefício da renda cidadã, não sabia que tinha benefício da bolsa família, não sabia de nada! Agora recebo o Bolsa Família, R \$100,00 para as três crianças, $\mathrm{R} \$ 31,00$ para cada uma. O renda cidadã eu também fui beneficiada, com $\mathrm{R} \$ 80,00$ por mês. Ajuda bastante!

Depois disso, fiquei pensando que eu preciso me informar mais. O meu aluguel é $\mathrm{R} \$ 550,00$, eu não tenho como pagar este aluguel, a médica do Posto de Saúde que se ofereceu para ajudar, se sensibilizou com minha situação, ela e outra amiga pagam o meu aluguel todo, os R\$ 550,00. Mas água e luz sou eu que tenho que me virar para pagar... Às vezes tudo isso dá $\mathrm{R} \$ 100,00$, outras $\mathrm{R} \$ 150,00$, um mês vem menos, outro mês vem muito, mas como eu divido o relógio com outra casa, fica difícil dividir tudo igual. 
Foi uma imigração não planejada, que virou uma história de vida

Aí depois de tanto me falarem sobre o "Minha Casa Minha Vida", fui me informar, ao invés de pagar o aluguel, você paga a sua casa. E eu não sou mulher de ficar sentada, eu vou correr atrás. Vou tentar, vai que dá?

E lembrar que tudo começou com eu tentando falar "próxima desce". Olha como eu sobrevivi! E ainda aprendi o português!

Falaram-me assim: "Dora, você tem duas crianças em tratamento, a Mila tem preferência porque ela é cadeirante, então vai lá na prefeitura, se cadastra, em vez de pagar aluguel você paga sua casa". Achei esta ideia maravilhosa, ia ser um sonho ter minha própria casa, não falo por mim, falo por meus filhos, é meu sonho ter uma casa, não interessa se só de dois cômodos, mas eu quero que seja minha casa, porque não sou eu que pago o meu aluguel, tem umas pessoas que estão pagando e é muito dinheiro, e eu não sei quanto tempo eu vou morar aqui. Se for 20 anos, são 20 anos pagando o meu aluguel, é muita coisa, eu tenho consideração com as pessoas!

Espero que um dia eu possa me virar sozinha, trabalhando. Talvez! Talvez daqui a dois anos, eu renovo o documento, e depois eu possa me naturalizar, naturalizar meus filhos, assim a Mila pode ter um salário-benefício, que vai ajudar! Ela vai poder estudar, vai comprar as coisinhas dela, o dinheiro dela, então eu vou correr atrás. Eu sei que tem que ir na prefeitura e perguntar. Não sei se tenho que ser naturalizada ou não pra poder ter. Tem também o "Minha Casa Minha Vida".

Mas vou deixar Deus para ver o que é bom. Sempre foi assim, e muito sonhos que eu tive foram realizados e ainda tenho muitos sonhos, como qualquer pessoa. Meu sonho era chegar aqui. Cheguei aqui, sofri, chorei, mas meu sonho, que era meu filho ter salvado o olho, e tem uma prótese e foi curado, isso é sonho realizado. O sonho da Mila, ela tá aí viva, graças a Deus com sete anos, é uma luta muito grande, ela já fraturou quarenta vezes, já quebrou quarenta vezes o osso, é difícil, é muita dor, mas sou mãe, uma mãe, uma mulher que sempre está de pé.

Hoje eu me sinto mais brasileira do que paraguaia! São dez anos, agora pelo menos 
eu já falo a língua (risadas). Já não penso em voltar a morar lá. Gosto de ir ao final do ano, mas aqui são muitas coisas mais cômodas. Por exemplo ônibus que o piso é mais baixo para passar a cadeira. Os remédios também. As pessoas boas que eu conheci. Aqui fiz muitas amizades. E as considero todas pessoas que eu conheço como cometas que passaram em minha vida. Mas tem outras pessoas que são estrelas, porque ficam. As pessoas boas que eu conheci aqui são estrelas, e moram no meu coração. Elas não passam, sabe, são estrelas muito boas (lágrimas). E uma estrela maior, Deus, que deu as outras estrelas para mim! (risadas). Continuar minha vida é minha luta, então essa história de cometa que passa e estrelas que ficam, são coisas boas que acontecem para mim, são estrelas que ficam. E como o tratamento é por tempo indeterminado, só Deus sabe o quanto mais tempo que eu vou morar aqui. Não tem dia, não tem hora, não tem data que o médico fala "ô acabou o tratamento". Então está nas mãos de Deus, mas eu sou muito agradecida.

Foi uma imigração não planejada, que virou uma história de vida. Dá muito mais de um livro! Porque o que eu acabei de contar é só o resumo da história! E sei que tiveram muitos percalços, mas meus filhos é a minha felicidade. Com eles eu nem consigo ver como foi tortuoso chegar até aqui. Esse amor tão grande que você tem pelo filho, me dá forças para passar tudo que eu estou passando. E o amor de mãe é infinito, não tem como explicar! Primeiro nasceu o Arnaldo, depois nasceu o Alan, já estava muito feliz, mas nasceu a Mila e foi a peça do quebra-cabeça que estava faltando nessa felicidade. A minha vida é difícil, são dias de muita luta, mas eu não reclamo, levo assim, eu estou vivendo o dia, estou vivendo o momento, não estou pensando “ah! o dia de manhã o que vai ser?”. Não, eu estou vivendo esse dia aqui, todo dia estou vivendo, estou rindo, estou brigando com eles, mas é aquela briga de querer educar, de querer ensinar! Graças a Deus tenho filho educado na escola, que só leva elogios! Eles falam para mim "ah! seu filho é muito educado", nunca recebi queixa da escola deles, e isso não tem dinheiro que pague! Isso não tem dinheiro que paga, porque eu sou mãe e pai aqui! Não é fácil corrigir três filhos! O pai liga, fala quando vem, vem visitar de quatro em quatro meses, ele me apoia muito na educação! Se ele sabe que eu estou querendo que eles tenham disciplina, ele me apoia, diz para eles que "se sua mãe fez isso, vocês estão merecendo". É, mas tem um lado bom e um ruim. O lado bom é que ele me apoia muito na educação, e é assim, se ele não está me mandando dinheiro, é porque não tem. Eu não estou defendendo ele, é assim que as coisas são. Só que minha briga é porque ele não procura outro emprego que pode ganhar melhor. Ele não se mexe, parece que fica sentado, puxa vida! 
Eu não espero nada sentada aqui, apareceu uma carteirinha especial para a minha filha? Vou atrás! Eu abri mão da minha vida! Ser mãe é cuidar da casa, da escola, do médico, eu trabalho, busco um tempinho para as minhas coisas, mas minha casa não é grande, mas também não é muita bagunça também, eu ensino meus meninos a ajudar, os brinquedos eles têm que guardar, colocar o sapato no lugar, brinquedo no lugar, então essas coisas ajudam! Eles me ajudam a arrumar a caminha, não é por preguiça minha, mas porque eu preciso que eles aprendam, porque eu falo assim, eu não sei se Arnaldo vai casar, eu não sei ele vai casar ou vai morar sozinho, então tem que aprender pelo menos arrumar uma cama.

A minha vida, se eu tivesse ficado em Ciudad del Este, Deus me livre, minha vida mudaria muito. Por exemplo, se a Mila quebrasse algum osso, eu não ia querer que ela fosse atendida lá não, porque eu já vivi uma experiência com Arnaldo, eu falei, acho que eu fui enganada, não por todos os médicos, também tem médico bom, mas eu fui enganada, acho que o oncologista mentiu quando disse que tinha calcificado o tumor. Poxa, era a vida do meu filho! A salvação eu devo para a doutora que mandou pra cá, foi que falou a verdade. Eu prefiro a verdade, por mais que seja muito difícil, eu prefiro a verdade, e não a mentira! Não me dê falsas esperanças! E foi o que ele fez, então eu agradeço muito ela, por eu ter migrado! Muito mesmo! Lá não teria um ônibus adaptado para cadeirante, precisaria ter um carro, porque se a minha filha quebrar qualquer osso, como que eu vou correr, ela no meu colo, sem ônibus para entrar com a cadeira? Quando eu vou para lá e chega o ônibus, eu tenho que desmontar a cadeira, mas a minha irmã me ajudou a embarcar no ônibus, ela segurou a Mila, e eu desmontei a cadeira, quando desci no ponto, para ir na casa de uma amiga, tive que deixar a Mila no chão para montar a cadeira. Um absurdo! Eu deixei ela em cima de um murinho, o Arnaldo segurou os bracinhos dela, e eu montei a cadeirinha. A diferença entre os países é muito grande, a comodidade que tenho aqui com ela, não seria a mesma coisa lá.

Lá também não teria a ajuda que eu recebo aqui. Minha casa mesmo está montada, com coisas que eu ganhei, coisas que me deram. Eu não comprei sofá, não comprei móvel, não comprei nada, puxa vida, meu sonho, se eu for ficar aqui mesmo, meu sonho é ter meu canto, minha casinha, aí que eu falo mesmo que eu não vou mais embora para o Paraguai, seu eu for embora é porque eu não consegui uma casa aqui pra morar, ou porque eu não ia ter mais condições de pagar um aluguel, mas se eu conseguir uma casa própria, aí é só de 
visita mesmo que eu vou para o Paraguai. Mesmo se fosse morar aqui só para eles estudarem, já ia valer a pena. Às vezes tenho até medo pela violência, que parece que tem mais aqui do que lá, e o que eu tenho medo mesmo é das drogas, pelos meus filhos. Tem que conversar muito! Eles vão na escola do bairro, uma é estadual, outro vai na municipal, o meu medo é o medo de toda mãe, das drogas.

Mas eu vou continuar a fazer o que estou fazendo, rezando e pedindo a Deus. Eu rezo assim: "meu Deus, meu pai, entrego meu filho nas tuas mãos pra que o Senhor os proteja de todo mal, de doença, de desrespeito, de abuso da rebeldia do mundo, das más companhias. Peço para ajudá-los a fazer o bem, e os abençoe”. Peço pra Deus, rezo, acredito, e continuo acreditando, porque o melhor presente que eu posso ter é ver meus filhos formados, educados, com profissão. Eu falo: "olha, filha, tem que estudar, tem que ter uma profissão. Ser empregada doméstica não é um defeito, mas se pode estudar e ter uma profissão, é o melhor que a gente pode ter".

\subsection{Cecília Lumbreras}

\section{Eu nunca quis sair do meu país}

Oi, eu sou Cecília Lumbreras, peruana. Nasci em Lima, a capital, e venho de um distrito de classe média, tive uma infância boa. Somos em cinco irmãos, e meu pai foi operário. Operário, mas ele sempre foi um homem muito trabalhador, deu tudo para a família, tanto que minha mãe nunca precisou trabalhar.

Eu sou a segunda filha, a mais velha das mulheres. Meu pai conseguiu com muito esforço e sacrifício uma casa, na urbanização. Assim a gente não passou pelas angústias de construir uma casa, de andar em povoados, certas coisas que acontecem com muitas pessoas.

Eu estudei em meu país. Estudei na Universidade de Champagnat, fiz o curso de Educação. No meu país eu trabalhava! Eu me casei muito nova, com 24 anos. Meu marido era de Lima também, do bairro que eu morava. Mas ele conseguiu um emprego na Argentina. Um ano depois que a gente se casou ele foi para lá. Nesta época eu fiquei grávida, e tive filhos gêmeos, que morreram ao nascer. Fiquei muito triste, pois estava esperando as crianças e elas morreram ao nascer. Foi muito triste. 
Mas voltando, o meu marido foi para a Argentina, e eu nunca quis sair do meu país. Eu morava bem, então para que sair? Eu não queria sair, mas ele falou: "ah, você não quer vir para cá, então tenho certeza que você tem outro". Coisa clássica do homem. E eu tinha ficado na casa dos meus pais, não fui com ele. Eu queria ver como ia ser lá, antes de ir. Eu não queria ficar sozinha, então saí da minha casa e voltei para a casa dos meus pais, que estavam fazendo um novo empreendimento, e eu sentia que devia ajudá-los.

Meu marido fez muita pressão e acabei indo para a Argentina. Eu me casei muito nova, grávida de duas crianças gêmeas, que depois morreram, passei um ano muito deprimida. Ele trabalhava, então o ajudou a superar. E eu não o via, ele trabalhava de noite e de dia. E acho que eu não o conhecia muito bem. Não tínhamos muito contato. A gente não se conhecia, a gente não era companheiro, apesar de termos namorado bastante tempo. Mas com a distância vamos conhecendo quem é realmente a pessoa. E cheguei a conclusão que eu não o conhecia bem, não tínhamos contato.

\section{Eu me perguntava o que tinha feito para merecer aquilo}

Chegando em Buenos Aires, as coisas foram diferentes, pois descobri muitas coisas dele que eu não sabia. Por exemplo, quando morávamos juntos em Lima, ele evitava beber. $\mathrm{Na}$ Argentina, ele bebia. E eu percebi que ele lá sozinho bebia muito, não parava até consumir a última gota. Era um bebedor solitário, bebia sozinho mesmo. E ficava bêbado, e quando voltava ficava olhando para mim e para minha sombra.

Me perguntava: “quem é aquele cara que está aí?”. E eu respondia sempre, porque sou uma pessoa muito meiga, muito tranquila, na verdade eu não havia saído para a vida, não tinha trabalhado, só tinha estudado, e numa universidade religiosa. Eu convivia muito com clérigos, então não tive uma formação fora do mundo. Eu não saía do meu bairro, trabalhei tranquila, na escola que tinha que trabalhar, que me ensinaram. Então foi um choque quando eu o descobri, ele me agredia verbalmente e eu ficava calada. Ficava calada, calada. Até que fiquei grávida, e quando nasceu minha filha mais velha, me deu um click. Pensei: "este cara está me destratando muito".

E eu sozinha com ele lá. Eu nunca tinha passado por isso, meu pai nunca destratou minha mãe, eram pessoas muito doces, nunca nem brigaram comigo, eu nunca aprontei com eles. 
Eu me perguntava o que tinha feito para merecer aquilo. Assim, quando minha filha nasceu, foi a primeira vez que eu pensei em separar-me dele. Pensei, "vou me separar dele". Mas depois que nasceu minha filha mais velha eu pensei, não, agora que nasceu minha filha, eu vou esperar um pouquinho. Isso foi em 1994. Mas ponderei e pensei que aquele não era um bom momento, pois depois do nascimento eu fiquei supermal, o parto foi difícil. Foi natural, mas tive hemorragia, tive que tomar muitos antibióticos. Vinte e quatro horas depois que minha filha nasceu eu tive hemorragia, que muito difícil de controlar.

Continuei mal por muito tempo. O médico disse que era anemia. Mas não era, pois a anemia começou a crescer. Era meu segundo filho, Fernando. Eu engravidei dele dois meses depois que a mais velha nasceu, eles têm diferença de 10 meses.

E mesmo assim pensava o tempo todo em me separar. A situação começou a piorar, estava cada vez pior. Era agressão verbal, e muita violência física. Quando ele ficava bêbado, ele me agredia muito, muito. Ele só parava quando tinha um coma alcoólico, e aí ele ficava desmaiado. Houve vezes que eu fiquei como uma tola e eu não sabia defender-me. Eu ficava num canto e ele me agredia muito, e ele não parava. Cada dia que passava eu queria sair dessa vida. (lágrimas) Eu passei muita necessidade ao lado dele, e não podia sair, e ele tampouco trazia as coisas para cozinhar.

E eu com duas crianças. Comecei a pesquisar os benefícios sociais, e averiguei que o Estado dava leite para as crianças, davam três ovos por semana para cada criança, coisas assim. E comecei a trabalhar um pouquinho, trabalhava por horas fazendo limpeza. Trabalhava na limpeza mesmo, já que eu não tinha documentos e não podia fazer um curso, ou estudar, nada que me ajudasse. E mesmo se eu quisesse, ele nunca ia me deixar, tanto é que quando cogitei isso ele me deu uma surra! Uma surra! Chamei a polícia, e eles falaram que não poderiam fazer muito porque ele havia caído. Então eles me aconselharam que eu fosse embora. Mas eu não tinha para onde ir, não tinha parentes, e eles me aconselharam ir para um abrigo, em Buenos Aires. Era um abrigo para mulheres sozinhas com filhos. Comecei a viver nessa casa, meus filhos começaram a ir para creche, e eu comecei a trabalhar.

Eis que um dia eu voltei e minha filha mais velha não podia respirar, do nada, de uma hora para outra. Tomou banho no inverno, saímos do meu quarto, e foi do nada que não podia respirar, e eu falei: “nossa, o que é que aconteceu?”. Ela tinha dois anos e meio, e não 
podia respirar. Levei ao hospital, desesperada, e lá falaram que era pneumonia. Os médicos falaram que eu tinha salvado a vida dela, porque ela havia chegado na hora, pois dez minutos a mais ela morreria. Ela ficou um mês em cuidados intensivos, uma bolha líquida havia se instalado no pulmão e ela precisava fazer uma operação no para tirar a bolha, e eles não poderiam fazer nada porque eu não tinha documentos, e as crianças estavam sem documentos, estava com o pai dos meus filhos. E precisava da autorização dele.

Nossa, eu tive que ligar para ele e falar onde eu estava. Desde que eu tinha saído de casa ele nunca tinha me procurado. Mas por milagre de Deus, não precisei de nenhum favor dele. Fizeram uma tomografia na minha filha, e a bolha se dissolveu, e ela não precisou operar. Dois meses depois ela saiu do hospital, e os médicos falaram que ela não iria ter uma vida normal como as demais pessoas, porque o seu pulmão esquerdo nunca ia ser normal, enfim, falaram que ela não poderia ir a uma creche, e que teria que ter cuidados permanentes. Mas eu tinha que trabalhar..... E assim, com dó no meu coração, com dó de tudo, eu tive que voltar para o pai dos meus filhos, era a única opção que estava em minha vida realmente. Foi outra das opções que tive que tomar, porque não tinha outra saída. Não tinha outra saída!

Ele nunca me deixaria voltar para o Peru, pois ele nunca me daria a permissão para sair do país. É necessário, quando se vai sair do país com crianças, que o pai autorize. E eu sozinha não poderia criá-los. Tive que ter esta decisão, uma escolha na minha vida. E essa que foi a escolha, voltar para ele. Só que com a cabeça mais fria, pensando que depois daquela opção, de tudo o que aconteceu e de eu ter saído de casa, eu saberia lidar com ele.

E pensei: "vou a revelar-me". E foi o que comecei a fazer, a revelar-me, e deu resultado. Deu mais resultado do que ficar quieta, submissa. Mas mesmo assim fiquei grávida da minha terceira filha. Eu estava me protegendo, tomando umas pastilhas que estavam dando no centro de saúde, mas eram muito fraquinhas. Então eu engravidei, mas demorei a saber.

Quando soube que estava grávida eu fiquei pensando: “meu Deus do céu, como vou fazer para criar esse filho. E ficava dia e noite pensando em como eu ia escapar com os meus filhos. Tudo o que pensava era escapar-me, queria dar uma vida melhor aos meus filhos, queria que estivesse bem de saúde para melhorar um dia. Minha terceira filha nasceu, e foi como uma resposta de Deus. A criei em um canguru, este porta-bebê. Eu falo sempre 
para ela que eu tenho uma mão para um filho, outra para a outra e para a Jaqueline eu criei com o coração.

Mas a situação não melhorou com o meu ex-marido. A minha filha tinha dez meses, e ele queria bater em mim. E eu escapei da surra. Desta vez eu gritei, e falei "se você me bater será muito pior”. Ele desligou a luz do apartamento, meus filhos choravam e ele falou para mim, que estava do lado de fora: "se você não entrar, eu não vou ligar, você vai ser culpada pelo o que acontecer com eles". Eu chorei, e entrei em casa, e fui para o outro lado da mesa, e ele não me atacou, pois eu estava protegida pela mesa, e como ele queria bater em mim, não me atacou. Ele não quebrava nenhuma coisa quando batia em mim.

Então ele abriu a porta da casa e falou: "você não quer morar mais comigo? Se você quer se separar de mim, vai embora agora, não vou dar a separação". Eu escapei para a rua, mas queria levar os meus filhos. E ele falou: "não vou deixar você ver nunca em sua vida os seus filhos". E fechou a porta. Depois, como estava muito bêbado, teve um de seus comas alcoólicos e ficou ali caído no chão. Eu dormi na porta. A minha filha mais nova tinha dez meses, ela mamava em mim, e ficou lá chorando a noite toda. Nem incomodou o pai com seu choro.

E eu do lado de fora! Às seis da manhã ele abriu a porta, e jogou a minha filha, e gritou: "ela incomoda muito, fica com ela". E a jogou para mim, e ficou com os outros dois, um com três anos e a outra com quatro. Continuei na porta da casa. Quando ele dormiu, eu fui até a polícia, mas eles falaram que não poderiam fazer nada. E fui ao Conselho da Mulher, em Buenos Aires. Lá eles falaram que também não poderiam fazer nada, porque eu estava casada e tinha tanto direito de ficar com as crianças, como o pai. Voltei à polícia, eles foram até a casa, e falaram que ele estava tomando banho, mas que parecia ser uma boa pessoa. E como ele não estava alcoolizado nem nada, eles não poderiam fazer nada.

Então a única solução para mim era a justiça. Fui a uma juíza no dia seguinte, a juíza falou que não poderia atender-me, porque tem que ser com um pedido. Eu resolvi não ir embora da porta da juíza. Fiquei ali sem me mover, sem ir a nenhum lado, eu falei: "eu não vou a mover-me daqui", e não me movi. Com minha filha menor fiquei das oito, nove, dez, onze, uma da tarde na porta do juizado. A secretária da juíza me perguntou: "senhora, você não vai almoçar?”. Eu respondi: “vou ficar aqui na porta até que atenda, porque não é proibido ficar na porta, né?’. Chegou três horas da tarde e a secretária me falou: “senhora, a 
juíza quer saber qual o seu caso". E eu expliquei, e a juíza me disse: "você é nova, você tem uma filhinha, vai e faça a sua vida". E eu falei que a minha vida não vai ser nunca completa se eu não estivesse com os meus três filhos comigo. E ela continuou: "Você sabe no que você está se metendo? Como vão viver, onde vão morar?". E eu decidida respondi: "no começo eu vou morar em uma casa, um abrigo, e depois, em uma hospedagem”.

E foi assim, depois de muita insistência, ela me deu uma ordem judicial, dizendo que eu poderia pegar meus filhos. Eu estava tão feliz, eu fui até a polícia, e o homem de guarda me viu e já falou: "moça, de novo você, a gente te falou, não podemos fazer mais nada". E eu falei "agora venho com uma carta de uma juíza”. Ele não acreditou. E eu estava com a carta em minhas mãos, e ele ficou impressionado.

Fez um telefonema, e pelas suas frases, "sim, sim senhora, ela está aqui, sim. Sim, sim”, eu sabia que ele estava falando com a juíza pessoalmente. Eu sempre lembro do nome dela, Artucha de Aires! E nem nunca me esqueci do dia em que ela me deu a ordem para ficar com meus filhos. Eu falei que lhe ia dar muitas orações, e sempre, em alguma oração, eu rezo por ela. Porque ela me ajudou.

Então, a polícia foi comigo, com três viaturas, veja só. Cheguei lá, ele falou para a polícia quando nos viu, em um tom muito gentil, educado como sempre: "ah, vocês não sabem, eu já falei, não vou deixar os meus filhos". E o policial falou que isso era uma ordem da juíza. Ele ficou me olhando, e duvidou. O policial reafirmou que era uma ordem de uma juíza e disse que ele tinha que me dar as crianças, do contrário seria preso. Ele ficou sem jeito, mas não perdeu a oportunidade de me falar: "as crianças ainda não sabem trabalhar, você nunca trabalhou em coisa pesada, você não sabe da vida, você vai voltar amanhã e vai pedir a mim que eu pague uma pensão a você”. Eu olhei para ele, peguei os documentos dos meus filhos, só a roupa que estavam vestindo, voltei e falei para os meus filhos: "vocês vão comigo. Eu não prometo dar riqueza nessa vida, mas eu vou dar amor para vocês". E eles me abraçaram e falaram que iam comigo. Eu os peguei e fui embora, não tinha nenhum peso quando eu saí, não tinha nenhum peso, sabe?

\section{Irmãos, preciso ir para Brasil}

Cheguei na estação de metrô e pedi para a moça que estava na estação: "moça, eu 
preciso pegar o metrô, mas não tenho dinheiro para a passagem". A mulher abriu e me deixou passar. Não sabia para onde ia, lembrei de uma amiga, e fui até a casa dela. Ela não estava, eu fiquei na porta sentada, com as crianças, até que ela chegou, à noite. Eu expliquei a situação, perguntei se podia dormir lá, e ela, uma pessoa muito boa, deixou a gente ficar lá.

No dia seguinte saí para procurar algo. Pedi a Deus para me indicar o caminho, e de manhã, eu saí e sabe, a primeira coisa que veio na minha cabeça foi a praça. Cheguei a essa praça, minha filha estava brincando, e do nada uma pessoa gritou: "Cecília!”. Era uma mulher que eu conheci no abrigo, e ela lembrava de mim, era uma boliviana. Nos cumprimentamos e ela perguntou o que eu estava fazendo. E contei toda a história, disse que tinha me separado, estava com os meus filhos, e falei que não sabia o que ia fazer. E ela falou assim: "Cecília, eu vou trabalhar amanhã, mas as crianças vão ficar em casa porque é feriado e eles não têm com quem ficar porque eu moro na vila". A vila é como uma favela.

Aí ela perguntou se eu não ficaria na casa dela cuidando das crianças, por dez dias. E ela ainda podia me pagar! Eu não tinha onde ir, e nem onde trabalhar, eu fiquei dez dias ali. Depois que passou dez dias, ela me pagou, e eu não só consegui um trabalho, como a casa que eu aluguei, de um uruguaio, fiquei sem pagar, pois o dono morreu de ataque cardíaco!

Acho que foi uma ajuda de Deus! Para completar, fui a uma escola perto de onde eu morava, e tinha vaga para os três, em jornada completa! Com eles estudando o inteiro, pude conseguir um trabalho melhor, e comecei a trabalhar por horas. Do meu primeiro trabalho, fui indicada para trabalhar em vários outros lugares. E comecei a ganhar o meu dinheirinho, não tínhamos grandes coisas, porque o que eu ganhava não era muito, dava para comida, para roupa, comprar o que a gente precisa, comprar uma panela, uma televisão, então vai comprando, vai pagando devagar. As necessidades básicas eu dava conta, e de vez em quando íamos ao McDonald's. Uma vida tranquila, básica.

O trabalho era limpando. Trabalhei em uma casa que me recomendaram, trabalhei em uma padaria limpando a padaria. O trabalho era de limpeza. Trabalhei para um Juiz, que foi ótimo, pois consegui todos os tipos de documentos com ele.

O chato é que o pai dos meus filhos sabia onde morávamos, e ele passava de vez em quando lá para ver se me via com alguém. Meus filhos tinham muito medo dele, eles pensavam que um dia ele ia me matar. Isso era o que eles pensavam, eles pensavam que eu 
ia morrer e sempre andavam com medo, e tudo isso repercutiu com minha filha mais velha. Minha filha mais velha teve colesterol infantil.

Ela adoecia com frequência, e eu a levava muito ao médico. Uma vez ele me falou que ela não tinha mais de seis meses de vida. Se continuasse a viver desta forma. Ele disse: "moça, você tem que ir a algum lugar para levar a sua filha e deixar esse meio". E eu pensei, "tenho três irmãos que moram aqui no Brasil, pode ser uma boa ir para lá". E eu nunca quis vir para o Brasil, primeiro porque eu não tinha permissão para sair da Argentina, segundo porque é um lugar que eu não sabia o que tinha. Liguei para eles e falei assim: "irmãos, preciso ir para Brasil. A situação esta difícil, minha filha está com colesterol infantil, será que vocês acham que eu teria oportunidades no Brasil, vocês me ajudariam a procurar um trabalho e uma casa?". E eles disseram que sim, que até tinham uma casa perto de onde eles estavam morando.

E eu precisava sair de lá mesmo. Uma junta de médicos me chamou e começaram a falar que por conta do colesterol, o sangue da minha filha estava virando óleo, e isso parece que a está matando. E eles mesmos me aconselharam a sair da cidade, da província, ou ir ao interior. E eu, como não conhecia ninguém na Argentina, pensei que vindo ao Brasil eu teria ajuda dos meus irmãos e ficar longe do pai dos meus filhos.

Só que, para eu sair do país, eu precisava da permissão dele. E então fui procurá-lo para pedir a bendita permissão. E ele falou assim para mim, "você sabe que não pode sair do país, senão é sequestro de meus filhos." Mas ele nunca deu um centavo, sabe? E eu insisti, falei que tinha a recomendação dos médicos, e que a Jaqueline estava morrendo. E ele olhou para mim e falou, "tá bom, eu vou dar a permissão para você, mas a Emily vai ficar aqui comigo". Eu falei que não, se ele não desse permissão para todos eu não poderia ir embora. E ele disse assim, nem posso acreditar: "então que a Jaqueline morra, não me interessa".

Sempre, sempre ele tem as suas chantagens. Mas eu falei que eu pagaria tudo, que ele não precisava dar nenhum centavo. E ele aceitou assinar. Eu usei um dinheiro que eu tinha guardado, dei para ele para ir de táxi ao cartório. E ele ainda disse que eu tinha que pagar as taxas. E eu menti, dizendo que todo o meu dinheiro tinha acabado, mas a minha irmã tinha pela primeira vez me mandado dinheiro daqui do Brasil. E ele olhou para mim e disse que ia junto comigo para economizar. $\mathrm{Na}$ verdade eu falei para ele que ia fazer esta permissão de viagem, mas que eu ia voltar quando a Jaqueline se curasse. Ele me pediu uma 
garantia que eu ia voltar. Eu peguei as chaves da minha casa e falei: "a garantia é esta. Ninguém vai de um país a outro deixando todas as coisas." E ele falou: "certo, é verdade, ninguém se vai e deixa todas as coisas". E essa foi a garantia que eu deixei que ia voltar.

Peguei um táxi e cruzei a fronteira do Brasil, sem fazer minha entrada legal. Assim foi como eu entrei no Brasil

Mas eu comprei essas sacolas grandes de plástico importadas, porque não tinha dinheiro e elas são baratinhas, e coloquei todos os cobertores que tinha, todas as minhas panelas, e trouxe. Eu falava que estava indo para a guerra, então tinha que vir pronta, porque eu não tinha nada. E eu saí tão apressada, queria tanto sair da Argentina, que nem me dei conta que o meu passaporte tinha vencido naquele dia. Só percebi na fronteira, que os guardas me falaram que eu não ia poder sair da Argentina. "Por que não, se eu nem sou argentina?", perguntei. E eles me mostraram que o meu passaporte não estava em dia, tinha vencido no dia anterior! E eles não iam me deixar sair. Tinha que voltar e fazer o documento. Eu chorava muito! Por um dia! Mas lei é a lei. Só que eu não tinha mais dinheiro! Se eu voltasse para fazer os documentos eu não teria dinheiro para voltar!

Aí eu falei: "eu preciso falar com sua chefe." Mas a chefe dele estava em viagem, no Paraguai, para a posse do presidente do Paraguai, e só voltaria no dia seguinte cedo. E eu resolvi ficar na fronteira. E a fronteira com Foz do Iguaçu é uma fronteira desabitada, não tem uma cidade do lado, a cidade está a quinze, vinte minutos. A sorte que no ônibus da Pluna, eles davam lanches, e a gente para economizar, só comeu dois, mas nós éramos quatro. Me reuni com a crianças e expliquei a situação: "crianças, só tenho dois refrigerantes, e um pacote de bolacha. Ou a gente fica aqui ou volta para Buenos Aires". Eles responderam que não iam chorar e ainda iam economizar o pacote de bolacha.

Então, esses dois refrigerantes foram o que eles tiveram de jantar para este dia. Eu peguei os cobertores que levava e coloquei em um banquinho que havia ali para que meus filhos pudessem dormir. A noite em Foz do Iguaçu é uma noite muito fria, fria, fria e gelada. Os guardas da aduana me viram ali e falaram que eles iam fechar a aduana às $23 \mathrm{~h}$, e que eu poderia ficar na sala. Eu entrei, e fiquei com meus filhos, agora bem mais quentinho.

De manhã, no dia seguinte, pode não ter mudado muito a vida destas pessoas, mas o 
que eles fizeram comigo, nesse momento que eu precisava, foi indescritível. Eles pagaram o almoço, deram chocolate para as crianças, café com leite para mim, e um salgado. As crianças estavam com muita fome e comeram muito. Estavam com muita fome, não haviam jantado né? Ai, foi de Deus!

A delegada da fronteira chegou oito horas, já haviam ligado para ela, porque eu liguei para as minhas irmãs, que ligaram para o Ministério das Relações Exteriores, explicando que eu estava sendo bloqueada na fronteira, que não me deixavam sair. E elas explicaram que eu não sou cidadã argentina. Mas eles falaram que eu não estava lá. $\mathrm{E}$ combinaram comigo: "você pode ir embora, mas você tem que dizer que nunca passou por essa aduana, tem que falar que não sabe por qual aduana passou. Porque pela lei, você não pode sair para o exterior se não tem todos os documentos."

E eu falei que não tinha dinheiro, eles falaram que não era isso que queriam. Peguei um táxi e cruzei a fronteira do Brasil, sem fazer minha entrada legal. Assim foi como eu entrei no Brasil, peguei o ônibus Pluna, desde Foz e cheguei a São Paulo. Meus irmãos estavam em São Paulo. Chegando aqui, minha filha estava muito cansada, com fome, e no terminal, eu não sabia falar nada de português, e eu mesma fui ligar para a minha irmã e falei em espanhol: "moça, a senhorita por favor, me dá un plato com pollo frito, ensalada, papas, e un poco de arroz”. Quanto que é? Ela falou, $\mathrm{R} \$ 15,00 \mathrm{com}$ um suco de laranja. Paguei e falei: "por favor, leve para as crianças que eu vou fazer uma ligação". Eu falei para as crianças que ia chegar a comida e fui ligar para a minha irmã. E eles levaram um prato com arroz, ovo frito, carne, salada e batata frita (risadas). Tudo errado! Ah, o suco de laranja, foi o único que foi o que eu pedi.

Quando voltei, eu olhei assim, “ah, isso não pedi! Mas deixa, deixa, que está muito gostoso". E eles estavam com tanta fome, que eles comeram tudo o que havia no prato, não deixaram nada, um prato inteiro comercial, comido por crianças de cinco, sete e oito anos. Eles estavam mortos de fome mesmo!

Minha irmã morava na Mooca, mas as outras duas e meu irmão moravam em Interlagos, e foi lá que eles tinham encontrado uma casa para mim. Eu cheguei sábado, meu cunhado queria levar as crianças ao shopping, meus filhos estavam muito cansados, com sono, não dormiam direito há dias. E a Jaqueline, que estava doente, quando chegou aqui, ela começou a caminhar e a saltar como se nada tivesse acontecido, como se não estivesse 
mais doente.

E meu cunhado queria nos levar ao shopping, e fomos ao shopping. Meu filho começou a chorar no meio do shopping pois ele queria ir dormir. Não queria estar no shopping, chorava, meu cunhado falou: "ai, que malcriado seu filho". As pessoas não sabem as coisas que temos que atravessar e nos julgam. As pessoas não sabem o que é a vida. E eu fui embora do shopping.

Na segunda eu ia começar a trabalhar, eles tinham conseguido um trabalho para mim de professora de espanhol, na empresa Wide. Eu comecei na Wide, um laboratório farmacêutico, que fica em Itapevi, outra cidade. Eu tinha que ir de salto, bem arrumada e eu não tinha nada! Minha irmã comprou para mim, me deu suas roupas.

Eu comecei a trabalhar, dando aulas de espanhol. Trabalhei na Johnson \& Johnson, na Avenida Nações Unidas, fui dar aula em Osasco. E morava em Interlagos! Uma vez estava no trem em Osasco, na estação e um moço me cercou e falou assim para mim, com uma arma dentro de um papel de jornal, "sua vida corre perigo". Ele estava me assaltando, e eu não fiz nenhum movimento de susto, não sei como não me emocionei, e falei: "moço, eu não entendo português". E virei, e segui caminhando como se nada tivesse acontecido. Parou o trem, o moço ficou olhando para mim, subi no vagão, quando olhei para a minha mão, eu tremia! Uma moça perguntou se eu estava passando bem, e eu respondi que sim, mas eu estava pálida, tremendo, depois que passou. Foi uma obra de arte, de teatro! Sou uma atriz praticamente! (risadas)

Mas dar aulas, apesar de ser muito melhor do que fazer faxina, não estava me dando estabilidade, eu não ganhava muito, andava muitas horas, porque eu não tinha carro. Para ir de Interlagos até Itapevi, tinha que sair quatro e meia da manhã, para começar a aula às sete horas, ou às oito. Quatro e meia, quando o primeiro ônibus saía, eu estava lá. E meus filhos ficavam sozinhos, mas eu tive muita sorte, pois quando eu cheguei iam inaugurar um $\mathrm{CEU}^{88}$ bem do lado de onde eu morava. Aí eles ficavam no CEU, os três. Uma brasileira deu a vaga para os três, no ensino primário e no ensino fundamental. E outra brasileira foi reclamar para a diretora: "eles são estrangeiros, acabaram de chegar e você deu a vaga para eles, eu estou na fila antes deles, eu tenho mais direitos que eles". A diretora falou que tinha oportunidade para todas, independente da nacionalidade. Bom para mim! E assim começou nossa vida em

${ }^{88}$ Centro Educacional Unificado. 
São Paulo, já vai fazer quase dez anos, cheguei em 2003, uma vida cheia de sacrifícios. E continuei dando aulas, e até que consegui juntar um dinheiro.

E a minha filha se curou completamente. Foi diagnosticado que era psicológico. E quando cheguei ao Brasil, fui à igreja de Santa Rosa, e eu chorei tanto! Fiz uma promessa que eu ia cozinhar por alguns anos se minha filha se curasse, e ela se curou. E eu fiz minha promessa, cozinhei durante oito anos seguidos. Meus filhos me ajudavam, até ano passado, vinham aqui, e depois levavam. E foi assim.

\section{Mudar para o Brasil foi o começo da minha vida, o começo da minha história}

Uma amiga minha, que morava na Argentina, trabalhava na casa de um homem que era gerente geral de toda América da Telenova Internacional, que são cartões telefônicos internacionais. E a patroa dela comentou: "sabe, meu marido quer levar estes cartões ao Brasil, porque lá não tem cartões internacionais”. E não tinha mesmo nessa época. Minha amiga falou que o patrão "quer trazer a empresa Telenova para o Brasil, quer ter uma base aí. Ele quer levar esses cartões a vocês que são peruanos, tem muito peruano em todas as partes do mundo. E eu falei que tenho uma amiga que mora e trabalha no Brasil, por isso que estou te ligando". E ela tinha ligado para mim, e eu falei que topava vender estes cartões. E eles vieram para cá e me contataram. E eu disse: “olha, eu sou peruana, e os peruanos, como as outras nacionalidades, temos tribos. A gente se encontra em lugares que se encontram peruanos, assim como tem lugares que se encontram bolivianos, colombianos". Hoje eu sei que não são tribos, e, sim, comunidades!

E a colônia peruana se reunia nesta época na Av. Rio Branco. Ainda seguem se reunindo lá, mas antes eles se reuniam na porta do Hotel Itaúna, seis horas da tarde, chegavam de qualquer lugar de São Paulo. Todos os dias os peruanos se encontravam lá e havia umas senhoras que vendiam comida na rua. Comida peruana. E lotava este quarteirão, era um quarteirão que não dava para caminhar de tanto peruano que tinha. Muitos eram ilegais, então eles moravam nos hotéis pequenos do centro. E é só perguntar para um peruano: "oi, como está? Onde se reúne a comunidade, em que lugar, quais dias, quais horários?". Parece mentira, mas isso não precisa ser divulgado porque o boca a boca é a melhor forma de divulgar. 
E eu morava em Interlagos, não tinha este contato. E fiz esta experiência, perguntei onde encontravam os peruanos e fui lá. Quando o pessoal da empresa chegou, eles falaram que eu precisava vender os cartões. E me perguntaram se eu queria ganhar comissão ou um salário. E eu preferi um salário por mês, para ser mais garantido. E foi bom, porque pude mudar para o Belenzinho, saí de Interlagos. E deu para juntar um dinheirinho. Com a venda de cartões pude comprar tudo o que eu tenho em casa, os móveis, tudo. Fui pagando, parcelado, só vendendo os cartões.

E percebi que os bolivianos também precisavam de cartões para ligar para a Bolívia, e então comecei a vender os cartões telefônicos na Kantuta. E eles me aceitaram. A organização da praça queria tirar os telefones clandestinos, que se fazia muita chamada na feira boliviana. Então eles aceitaram. Eu fiz todos os pagamentos de taxas que tinha que fazer para ter autorização para vender. E o pessoal da praça Kantuta me cadastrou na prefeitura, porque eu não era boliviana, era peruana, e comecei com as vendas dos cartões.

Eu ganhei muito, muito dinheiro para a Telenova, na realidade. Para a Telenova, porque eu não quis a comissão. E eu depositava por semana para eles. Havia semanas que depositava dez mil reais, quinze mil reais da venda dos cartões. Se eu ganhasse por comissão, eu teria ganhado muito mais dinheiro. Porque quinze mil reais por semana, são sessenta mil ao mês. Se eu ganhasse 10\% seria seis mil, por mês. E seis mil é um monte de dinheiro. Ainda mais há dez anos.

E eu comecei assim, trabalhei, trabalhei, trabalhei um ano com eles, e ao término de um ano eu pedi para eles que eu queria ganhar comissão. E eles incentivavam, falavam que eu poderia ganhar mais vendendo em comissão. Mas foi justamente quando apareceram outros cartões. Chegou a concorrência, com o Mais, o Latino, um monte de cartões. Mudou também o meu chefe, que não era mais argentino, era uma brasileira, que queria que eu investisse meu dinheiro para comprar os cartões para revender. Quando o chefe era argentino, ele me pagava um salário e me dava os cartões. Chegava aqui em casa os motoboys que deixavam uma quantidade grande, de cartões, lotes de duzentas, trezentas caixas. E se vendia, vendia. Então eles entregavam. E conforme vendia depositava. Era em consignação. Com a brasileira, eu tinha que comprar, e eu não tinha dinheiro.

Eu não era uma pessoa que tinha vindo ao Brasil com um monte de dinheiro, vim com uma mão na frente e outra atrás, para curar a minha filha e fugir do meu ex-marido. 
Meus únicos tesouros são meus filhos! É o único bem de valor que eu trouxe para esse país comigo, os meus filhos. Quando morava em Interlagos, a casa que meu irmão conseguiu para mim custava $\mathrm{R} \$ 150,00$ o aluguel. É muito pouco, mas para mim era muito. E eu fazia feira, nas sextas-feiras só com dez reais, e dava pra semana toda. Aprendi aqui no Brasil a ir bem tarde à feira. E eu ia às 13h, e comprava as verduras e as frutas mais em conta. Eu ia ao açougue e pedia ao açougueiro: "moço, você tem ossos para o meu cachorro", e ele já sabia. E ele me dava uma sacola de ossos, mas muitos tinham carne, e nós o fazíamos ferver bem, e separava e fazia sopa. Em cada sopa que eu fazia, eu colocava verduras, legumes, um monte de coisa, e dava para os meus filhos.

Eu cozinhava um monte de tudo, mas de coisas muito em conta. E assim, cheguei aqui, comecei, não só dava aulas de espanhol, mas também vendia congelados porque eu pensei: “eu posso vender comida!", e comecei a congelar comida e vender, e as mesmas pessoas que eu dava aula, muitos precisavam. Diziam "eu preciso de tal congelado", perguntavam se eu podia achar, e eu já congelava e guardava as marmitas e levava. E isso dava para as coisas. Por mais que eu tenha trazido minhas panelas (risadas), vim com três crianças, que crescem, perdem roupas. Eu doei muita roupa para a igreja, as roupas de inverno da Argentina aqui não serviam de nada, mas ganhei muita roupa também.

A sorte que tive a ajuda dos meus irmãos no começo, que também dão aulas de espanhol. E na época que cheguei eles precisavam de pessoas qualificadas, e eu me considero uma pessoa qualificada! Não tenho os papéis, mas sei que sou uma excelente professora. E dar aulas no meu idioma, foi fácil para mim, ainda mais fazendo o que eu gosto. E não necessariamente foi o trabalho que me deu mais dinheiro, mas para começar foi bom, não precisei fazer coisas ilegais, graças a Deus. E parei de fazer faxina.

E foi assim, mudar para o Brasil foi o começo da minha vida, o começo da minha história. Comprei minha primeira cozinha nas casas Bahia, creio que pagava $\mathrm{R} \$ 10,00$ ou $\mathrm{R} \$ 15,00$ por mês. E tudo o que eu comprei foi em vezes, e nada com meu nome, porque eu não estava legalizada, então o crediário ficava no nome de um irmão ou de uma irmã. Tudo eu comprei assim, em muitas vezes, mas com o nome de outros, essa casa também não aluguei em meu nome, tive que alugar em nome de outros, e às vezes eu ficava muito triste, chateada, porque eu trabalhava nessa empresa dando aulas para diferentes empresas, em algumas eles depositavam na conta de outros, porque eu não tinha conta. E eu tinha que pedir para a minha irmã, para que por favor, eles depositassem na conta dela. Ela falava que 
não tinha problema, mas às vezes ela não tinha tempo para tirar o dinheiro e me dar. Eu tinha que esperar quando ela tinha tempo e às vezes a gente brigava. "Ai, Cecília, tudo bem, vou tirar o dinheiro, você não pode falar para que eles deem direto a você?’. E dizia que ia pedir, mas eu não tinha muito o que fazer.

"Você mora há tanto tempo sozinha com a gente, você não acha que é a hora de procurar alguém na sua vida?”

E assim fui crescendo, vendendo na praça boliviana, meus filhos estavam maiores, e eu conheci o Luis. Ele gostava muito de jogar futebol, e lá na praça tinha uma quadra. Um dia ele foi a jogar, passou por mim e perguntou: "moça, você vende esses cartões, como funcionam?". E eu expliquei para ele, e ele pediu o meu telefone e começou a fazer o pedido para mim. Ele pedia, e eu entregava as caixas. E ele vendia na zona onde ele morava, em Guarulhos. Um dia ele me ligou dizendo que precisava de uma caixa, mas eu não estava em casa, tinha que dar uma aula em Santo Amaro, e pedi para ele me esperar, eu já morava no Belenzinho. Ele falou que tudo bem, que me aguardava. E com o trânsito, eu cheguei super atrasada! E ele falou, que eu agora estava de castigo, que tinha que sair com ele para tomar um suco. Eu disse que tudo bem, e fomos tomar um suco de laranja, e fizemos amizade, fora o compromisso de venda, de negócio. E foi assim, da amizade, começamos a namorar. Um dia ele veio aqui, e minha filha mais nova, na época com seis anos, disse que ele estava me esperando. Eu falei para ela tomar café da manhã com ele, que eu ia tomar banho.

E ela perguntou, enquanto eles tomavam café: "moço, eu quero perguntar uma coisa para você, o que você tem com minha mãe?". E ele falou, “ah, temos uma relação de negócios." E ela: "você está completamente seguro do que está falando, tem certeza absoluta?" E ele: "sim, por quê?", E ela: “eu acho que não. Porque minha mãe nunca traz ninguém aqui em casa, então acho que vocês tem mais do que uma relação de negócios”. Olha como ela havia relacionado! E ainda completou: "e você então lembre de outra coisa, ela tem três filhos para manter, ela não está sozinha”. E ele ficou sem falar nada, quieto. Eu saí do banho, e ela falou que ia dormir, e voltou para a cama. E eu perguntei para o Luis, o que tinha acontecido. Ele falou: "a tua filha falou uma coisa para mim agora, mas não posso falar porque ela pode escutar”. Quando saímos, ele me contou, e quando voltei a casa, ela falou assim para mim: "mãe, eu quero falar uma coisa com você. Você sabe que pode confiar em mim, as coisas que você está passando talvez eu também passe, porque eu sou 
mulher como você. Você olha o seu coração e fala, você tem algo para contar para mim, tem algum segredo guardado em seu coração que queira compartilhar comigo?”. E eu disse: “não, não tenho nenhum segredo". E ela: “mãe, tem certeza?”. "Emy”, falei, e ela: "você sabe que pode contar comigo, que eu vou escutar teus segredos". Nossa, depois desta eu senti que eles precisavam saber, eles tinham o direito de saber. E eu disse que não contei antes porque não sabia se era algo que fosse durar, disse que não estava segura para contar. E pensei se eu não compartia um segredo com eles, eles também não vão compartir comigo quando tiverem um segredo. E a minha filha mais velha disse: "você mora há tanto tempo sozinha com a gente, você não acha que é a hora de procurar alguém na sua vida?”. E o menino falou: "vai ser fácil, se para você está bem, está bem para mim”. E a menor falou: “eu estou com você mãe, conta comigo".

E assim foi. Não fomos morar juntos de imediato. E eu continuei pagando minhas contas, com a minha vida e meus filhos, e ele seguiu em Guarulhos, com sua vida, suas coisas... Mas ele tinha um filho no Peru, ele tinha se separado da mãe dele praticamente depois que ele nasceu. E um dia me contou todo preocupado: "Cê, tenho meu filho, que está praticamente abandonado. A mãe dele o deixou, o que será que faço, eu não sei o que fazer! Será que eu o trago para o Brasil?”. Eu falei que ele tinha que trazer! Tem tantos pais “solteiros" pelo mundo, ele não podia deixar o filho dele lá sozinho! Depois de um ano ele decidiu, disse para mim: “Cecília, eu acho que já chegou a hora de trazê-lo. E quero saber se você quer morar comigo". Eu aceitei, foi muito difícil, ainda é difícil, acho, mas agora somos uma família de verdade. E o filho dele se acostumou bastante com a gente. Tanto é que as pessoas acham que ele é o padrasto e eu que sou a mãe! E não dá para perceber a diferença mesmo, porque é igual! Ele é bem-educado como os meus filhos, e ele se sente da família.

E o coração de mãe sempre aguenta mais um e mais outro. E eu que já fiz tanto pela vida dos meus filhos, tive que fazer tantas decisões importantes, deixei tanta coisa de lado. E no fim é como quando se cozinha numa casa, se você cozinha para dois, dá sempre um prato a mais. E o mesmo serve para as crianças. A felicidade é como um perfume, quando você dá perfume para alguém, este perfume sempre fica em você, nas mãos, no ambiente. E é o mesmo com amor. Quanto mais você dá, mais você recebe.

Se eu posso ajudar alguma pessoa, eu gosto muito de fazer, especialmente mulheres. Principalmente depois de tudo o que eu já passei na minha vida, como eu vivi, como eu 
consegui sair, ninguém imagina o que eu senti, como não dá para imaginar o que uma pessoa sente, se não viveu a mesma experiência. E as pessoas falam: "ah, este homem bateu na mulher, mas ela continua vivendo com ele, então ela deve gostar de apanhar". Mas não é necessariamente assim, mulheres latinas são mutiladas desde crianças, mutiladas psicologicamente. Porque nós moramos em um mundo machista, e nos ensinam a ter mentalidade machista também. Então para nós, tem coisas que estão bem, tem coisa que nos dão vergonha, para mim dá muita vergonha falar para alguém que eu apanhava. E quanto mais machucada, mais eu me escondia, para que ninguém me visse. Então eu ficava dias sem sair de casa, ficava escondida, porque não queria que ninguém me visse machucada. Eu tinha tanto medo que não reagia, eu não levantava a mão para em defender. Hoje em dia não, hoje em dia eu sou a pessoa que se vejo alguém me agredir, eu respondo, eu sou agressiva. Eu ajo com o que aprendi.

\section{Estrangeiro é como um filho sem pai, aqui não tem ninguém que te represente}

E por conta disso, de ter que lutar, tive forças para lidar com um grande dilema que todos os imigrantes passam: a Polícia Federal. Ser imigrante no Brasil é passar por vários dilemas. A discriminação é um deles. E não só a nível de governo, mas também a nível de comunidade. Se se quer alugar uma casa, e quando percebem que é para estrangeira, e não europeia, desconversam, falam que não tem casa para alugar. Mesmo se o imigrante mostra a placa de "Aluga-se", eles dão uma desculpa, falam que a casa já está alugada. Mais de uma vez isso aconteceu comigo. Diziam "Não, não estamos alugando para bolivianos". E eu dizia que não era boliviana, mas tanto faz. E na Polícia Federal, nossa, há tanta uma desinformação, um desprezo. Um destrato da pessoa humana.

Quando eu cheguei ao Brasil, clandestinamente, trouxe o boletim de notas dos meus filhos. Eu trouxe porque eu sou uma pessoa de guardar as coisas, o boletim da primeira, da segunda série... E foi só isso que eu trouxe que comprovava que meus filhos estavam na escola. E graças a isso os meus filhos puderam se matricular na escola. Traduzi o boletim, e só com isso eles matricularam independente de ter documentos brasileiros, só com os documentos argentinos. Como eu entrei de forma errada, e queria fazer tudo certinho, juntei dinheiro e fui com os meus filhos até a fronteira com o Paraguai, e fiz a nossa entrada de forma legal. 
E como o Brasil tinha um acordo bilateral com a Argentina, fui até a Polícia Federal, e falei que queria fazer o documento dos meus filhos, uma vez que eles eram argentinos. Entregaram os documentos para os meus três filhos. Iam entregar o meu, mas falaram eles mesmos perceberam que eu não podia, por ser peruana. E falaram que só iam dar para os meus filhos. O Luis estava comigo e eu falei que ele era meu marido e mantinha meus filhos. Mas eles não entregaram nada nem para mim, nem para o Luis, só para os meus 3 filhos. Meses mais tarde, eles anularam o protocolo dos documentos dos meus filhos, alegando que não podiam entregar documentos para meus filhos, se não tinham os pais documentados. Mas em um primeiro momento entregaram para os três.

Era tanta desinformação! A Polícia Federal disse para que eles tivessem o visto precisavam ir ao Ministério do Trabalho, mas chegando lá, ninguém sabia dar informação. Só falaram que a gente ia precisar de um advogado. E fomos falar com um peruano advogado, presidente da Associação de Estrangeiros, que falou para a gente entrar com um processo em Brasília, um processo de reunião familiar. Este processo já vai fazer quase dez anos e até agora nunca soubemos o resultado dele. Acho que eles não sabiam como resolver isso, pois meus filhos têm direito a documentos por serem argentinos, mas eu não tinha direito.

Em 2009, quando saiu a Anistia Migratória, fizemos sem problemas, mostramos todos os documentos Quando fui a fazer a renovação da Anistia, meses antes eu fui, averiguei com eles e não pediram em nenhum momento o documento dos meus filhos para mim, não pediram nada, falaram, esse documento é o documento de vocês. Quando fui fazer a renovação levei tudo, tudo certinho, paguei o INSS, a previdência social, fiz todas as coisas, pediram o boletim das escolas, as declarações, tudo direitinho. Levei as condições de trabalho, tudo. Chegamos lá na Lapa às oito horas da manhã, e saímos quatro horas. Mas me entregam o meu documento, entregam ao Luis, mas não entregam aos meus filhos nem o do filho dele.

Falaram que não correspondia, porque a gente não tinha a guarda dos nossos filhos. E aí começou toda a luta, uma luta muito grande, com muita perseverança. Sim, eu falo com perseverança, porque pediram o documento e fomos à Defensoria Pública do Estado, na Av. Liberdade, com os defensores do povo, e falaram que tampouco podíamos usá-los, porque a renda familiar ultrapassava a renda mínima para que pudessem nos assistir, então não iam poder entrar com o nosso processo de guarda judicial. E continuamos sem nada, fomos ao 
CAMI também, que nos fez alguns pedidos, mas não deu certo, porque nos indicaram um juiz da Penha que dá a guarda judicial para fins de regularização migratória, mas como não morávamos na Penha não podiam fazer nada. E assim foi, fomos a muitos lugares, iniciei um processo de guarda, mas o prazo esgotou, porque eu dei entrada aos documentos em maio, e no último dia que tínhamos que apresentar era julho. Veja: maio, julho. Dois meses, dois meses que eu corria quase todos os dias de um lugar para outro lugar. Mesmo assim consegui uma guarda provisória, e quando fui à Polícia Federal, com a guarda provisória, pensando que já tinha todos os documentos que me eram pedidos, as moças nos davam informações desencontradas.

Falaram que eu tinha que levar a certidão autenticada no consulado do país de origem. Fui ao Consulado Argentino e eles falaram que não podiam autenticar as certidões, pois o Brasil e a Argentina tinham um convênio que isentava a autenticação, e falaram que a única maneira era que eu fosse à Argentina, ao Ministério de Relações Exteriores argentino, que eles iam colocar um carimbo na parte de nascimento que diria que não precisa por convênio. Mas como eu estava com os documentos, eles nos deram todos os papéis, escritos em português e em espanhol, falando dessa lei. Quando eu voltei na Polícia Federal, a mesma moça nos destratou. Eu estava desesperada, ia todo dia perguntar, averiguar que requisito faltava, mas sempre falavam de um outro documento que faltava. E eu juntava, mas sempre precisava de mais algum outro. Eu colecionava as folhas da PF com requisitos, um diferente do outro! Um absurdo! Papel se estava indo para a escola, o boletim de notas, certificado de que está estudando, me pediam e pediam coisas.

E diziam: "Não, esse certificado tem que ser autenticado", "agora tem que ir à delegacia de ensino", "ah, agora tem que pôr o carimbo, não só da escola, mas do ensino regional”. Eu fiquei nervosa, e a moça me destratou de novo. Ela já me via e dizia "ah, de novo você". E eu falei para ela: "Moça, eu estou reclamando, eu não estou pedindo caridade! Eu só quero que você faça seu trabalho!”. Eu estava tão enfurecida.

Mas por causa desta minha história uns repórteres iam fazer uma reportagem comigo. Eu pedi para eles que filmassem tudo! E quando voltei para a Polícia Federal levei o papel dos requisitos, mas fui lá na fila e pedi para a moça me explicar melhor, disse que eu não entendia muito bem o português. Eu queria que ela anotasse, para depois eu ir em outra pessoa e mostrar a confusão. Então ela escreveu, porque é bom ter tudo escritinho, senão é a sua palavra contra a deles. E estrangeiro é como um filho sem pai, aqui não tem ninguém 
que te represente, ninguém que vai sair, ou vai deixar de trabalhar para ajudar a você.

Aí eu voltei para a mesma moça, mostrei os documentos e falei: “olha, aqui está o que você me pediu. Tem o papel emitido pelo consulado argentino. E ela, "não moça, eu não pedi isso", e eu disse: "pediu sim, olha aqui o papel com a sua letra". Ela teve a coragem de responder: "isso não sei, não me interessa". E eu estava com os repórteres do meu lado, filmando tudo, com a Polícia Federal superlotada, havia muitas mulheres com crianças nos braços, que não tinham sido atendidas, não tinha água, não tinha nada. Era um destrato à condição de ser humano, porque estavam nos tratando pior que porcos. Muito ruim.

E ela falando, negando que tinha falado, depois ela falou que não sabia, que só cumpre ordens que não sabia de mais nada. Ela foi falar com o superior dela, e aí eu vi que eles sabem falar outra língua, não só o português, como o inglês, o espanhol, e outro idioma mais. Mas eles fingem que não sabem. Mas o encarregado foi falar comigo falando espanhol. E disse: “olha, não precisa, você não precisa nem sequer tirar uma xerox autenticada do seu documento, porque a gente tem como puxar aqui e vai puxar para você, do computador, não tem que fazer nada, só que a gente está com muita fome, desculpe, não tomei café da manhã, atendi, estamos trabalhando o tempo todo, só vamos poder fazer o seu documento às duas e meia". Você acredita que eles fechavam na hora do almoço, e todo mundo tinha que ir para fora e esperar parado do lado de fora até às 14h30!? Com umas filas enormes.

Mas ele falou que os repórteres não podiam filmar, porque não tinham autorização. Por mim tudo bem, eles não precisavam colocar este pedaço no documentário, mas se eles não estivessem lá, eu não teria saído com os documentos, eles me ajudaram. Na realidade meus filhos voltaram esse dia e a Polícia deu para eles um documento por casos omissos. E receberam atendimento preferencial de casos omissos, e a partir disso, qualquer pessoa que pedia a renovação, mas eles tinham alguma dúvida sobre os documentos, era gerado um protocolo de casos omissos. E isso queria dizer que o caso era levado a Brasília para que averiguassem, e isso garantia que não iam perder a vaga, independente de demorar um ano, dois anos. E se sentirem faltam de qualquer documento eles iam mandar um telegrama.

E no meu caso no fim deu certo! Foi para Brasília, e saiu publicado do Diário Oficial da União como deferido! E se o que faltava era a autorização do pai, eu argumentei que para entrar no Brasil precisa de documentação do pai, e ninguém entra ao Brasil escondido, pelo 
menos criança, adulto pode até ser, mas criança é muito difícil. Acho que não tinha que ter tanta burocracia. Quando fui de novo para a polícia federal, tive que pagar de novo a taxa, que foi como duzentos reais para cada um. Mas isso não tem jeito, tem que fazer. E que bom que deu para pagar! Agora eles têm o documento permanente, assim como eu!

E se eles não tivessem o RNE, isso poderia comprometer o estudo deles, pois quando são crianças a escola não pede tanto documentos, mas quando você já passa ao técnico, ou já termina o colegial, precisa porque senão não entra na escola para estudar. Meu filho, vai à uma escola técnica, e a professora, diretora, não aceitava a matrícula, sem o documento. Eu chorava e chorava, porque eu não sabia o que fazer. Mas com o CPF eles aceitaram, só porque ainda estava em trâmite a documentação.

Foi um sufoco que passei, por causa dos documentos. Se a gente fosse marginal, tanto faz se não tem documentos, porque está na rua, essa gente não trabalha, não estuda, não faz nada. Mas quando é uma pessoa de bem, eu quero viver com as regras, está tudo certo, é necessário que o governo ajude. Eu acho que deveria dar mais ajuda para a gente que quer legalizar.

E tinha que ter uns postos da Polícia Federal itinerantes, para resolver os problemas de forma mais rápida. Na PF, tem que levar xerox autenticada de todo o documento do país. Se por algum acaso você esqueceu, mas leva o documento original junto, eles tinham que aceitar, pois um documento público oficial já tem a fé pública. Isso ficaria mais leve para nós imigrantes. E eles ganham bastante com o que a gente paga como estrangeiro. Olha, eu paguei para os meus filhos, fiz o pagamento de casos omissos, foi duzentos reais, que nos serviu só para dar esse tempo, porque eles estudaram os documentos dos meus filhos, eles não deveriam cobrar se eles só vão estudar. Mas eles estudaram, quando eles deferiram, tive que pagar de novo os duzentos reais.

É um absurdo, porque se a pessoa tem cinco filhos, cinco por quatrocentos, são dois mil reais. É muito dinheiro! E cada vez que se renova os documentos tem que pagar $\mathrm{R} \$ 200,00$, que é na realidade, $\mathrm{R} \$ 124,00$ mais $\mathrm{R} \$ 68,00$, quase $\mathrm{R} \$ 200,00$. 
Eu tenho muita vontade de trabalhar com educação aqui no Brasil. Gostaria muito de trabalhar com jovens, é o que mais adoro. Gostaria também de trabalhar com mulheres, mas por enquanto não dá. Por enquanto estou lutando para que os meus filhos se formem. Quem sabe mais para frente eu possa fazer um curso e outras coisas. Mas eu sempre tomo as decisões pensando nos meus filhos, porque são a minha razão de viver.

E antes eu trabalhava com esta venda de cartões. Eu fiz todo o trabalho de base, ensinei a muitos bolivianos a usar o orelhão, vendi em todos os pontos, caminhei por vários locais, não só São Paulo, mas também no Rio de Janeiro, Foz do Iguaçu, para muitas partes do sul, com os cartões, que eu fiz ser conhecido o sistema. Desbravei todo o caminho, mas como não tinha dinheiro para investir, tive que deixar os cartões. Depois de algum tempo, o presidente da Associação da Praça Kantuta falou para mim: "Cecília, lembra, você tem todos os documentos, está inscrita na prefeitura. Você não pode desistir de tudo!’. Mas falei que não tinha CCM, que só tinha $\mathrm{CPF}$, que isso podia dificultar as coisas, mas ele me falou que não era tão difícil ter o CCM. Mas eu também disse que eu não queria mais vender cartão. Então pensei: “vou vender comida peruana!”. E ele gostou da ideia, e já falou para eu começar naquele domingo. E eu não tinha nada, procurei uma amiga que disse que emprestava a barraca dela. Era uma barraca velhinha. Outra amiga disse que podia me emprestar duas mesas, outra umas cadeiras. E foi assim, eu levei só umas panelas, com as minhas coisas, pensei em três pratos de comida, um cardápio feito de um papelão branco pintado. As pessoas falavam: "nossa, comida peruana”. E eu super simpática, e falava para elas experimentarem. Meus filhos foram comigo, eles sempre me ajudam bastante. Acabou sobrando, e almoçamos todos juntos. Até brinquei, disse: "vocês não se queixem, porque eu trouxe vocês para almoçar fora, hein?" (risadas). E foi o começo, porque aí não paramos mais! Começamos a ir todo domingo, e foi crescendo. Antes era uma barraca emprestada, depois comprei uma barraca própria. O que eram cadeiras emprestadas, devolvi e comprei duas cadeiras próprias. Depois comprei mais outras duas barracas, mais mesas e cadeiras. Hoje tenho oitos barracas, e dois toldos, tenho seis espaços, dez mesas, e as cadeiras que tem nas mesas, comecei com uma emprestada, e tenho dez mesas hoje em dia. Faço mais de nove pratos, faço desde pratos salgados, sobremesas, faço suco de milho roxo, que faz um sucesso! Tem refrigerante peruano, cerveja. Meu público são brasileiros curiosos e peruanos. Pouco a pouco fui fazendo a minha freguesia. E eu quero cozinhar mais, mas é aos poucos, devagar, a comida acaba cedo, porque os peruanos vão almoçar cedo. Eu poderia vender outro tipo de comida, outra coisa, em um horário mais tarde, mas preciso me 
equipar. Mais pra frente quem sabe, compro uma perua. Hoje em dia eu tenho que fazer duas viagens, porque temos um carro que não é muito grande. Mas vou devagar, passo a passo, sem tentar correr, caminhar primeiro firme. Tenho apenas dois anos e meio na Kantuta.

Quando precisei provar que trabalhava, para renovar meu documento de provisório para permanente, tive como comprovar, tenho um certificado com foto e tudo. Tenho até um número de feirante.

E creio que não volto mais ao Peru para morar. Meus filhos nasceram na Argentina, mas foram criados no Brasil. Eu não tenho raízes aqui, mas estamos criando raízes, e meus filhos já estão abrasileirados, para eles Brasil é seu país. Eles falam muito bem português, também falam muito bem espanhol. Mas eles estão muito acostumados com o Brasil. Eu já vim grande, eu nunca vou falar português bem. Mas eles não, para eles isso é a sua vida, isso é seu país. Só voltaria ao Peru para morar se meus filhos fossem comigo. Se não, eu vou a ficar aqui, sempre, mesmo que já não estejam morando comigo, e morem já em casas, eu quero estar sempre perto deles, no mesmo Estado. Para qualquer coisa que eu ajude, uma vez mãe, nunca se deixa de ser mãe. E eu não quero, não tenho vontade de deixar de ser mãe.

E assim, acho que vou continuar morando aqui no Brasil, por muitos anos. Eu vim para cá de repente, não foi uma migração planejada. De todas as minhas amigas, quando eu tinha dezesseis anos, elas pensavam em morar na Venezuela, ou outro lugar. E eu não pensavam em sair do Peru. Talvez seja por isso que eu não fale tão bem o português, como se fosse minha revolta! Revolta e desejo de estar aqui sem querer, inconscientemente.

Eu me senti nesta vida como uma folha ao vento nas mãos de Deus. Porque ele guiou meu caminho, minha vida, e ele me trouxe a esse país. E se ele trouxe a minha família neste país, foi por alguma razão. E eu não vou mudar-me de Brasil, a menos que o caminho seja mudado. E algo apareça em minha vida. Eu não, eu sou a pessoa que acha que as pessoas não se conhecem sem motivo. Porque assim, tudo tem uma razão de ser, e eu vou a seguir o que está destinado para mim. 


\section{O TRABALHO E A MIGRAÇÃO EM SUAS HISTÓRIAS}

\subsection{Maria Cristina Romero Alvarez}

\section{Desde que vim para cá tudo mudou em mim}

Meu nome é Maria Cristina Romero Álvarez, tenho 25 anos, sou imigrante e vim para São Paulo há um ano e meio. Sou paraguaia, de Luque, e sempre morei com minha mãe.

Antes de vir para cá estudava, estava na faculdade e trabalhava. Mas os trabalhos eram inconstantes, eu trabalhava e largava o emprego. Na verdade lá no Paraguai é diferente daqui, se trabalha por três meses e depois te mandam embora, para não pagar o seguro. Para se conseguir um trabalho lá precisa ter alguém que consiga para você e se for alguém do campo político, melhor. E se a pessoa não é colorada, ${ }^{89}$ não tem trabalho. E eu e meus familiares não somos colorados, ainda bem!

Não somos colorados e nem queremos fingir que somos, só para ter um trabalho. Minha mãe é aposentada, mas ela foi enfermeira, e sempre me ensinou que o trabalho serve para sermos autossuficientes, para conseguirmos o que queremos, e que para isso devíamos estudar.

Somos quatro irmãos, três homens e eu sou a única mulher. Quando eu decidi que queria vir ao Brasil, liguei para o trabalho de minha mãe e contei. Ela disse: "filha, deixa eu pensar. Estou trabalhando, te ligo de volta e te digo se pode ir ou não".

Fiquei muito ansiosa com a resposta. Uma amiga me convidou para vir para São Paulo com ela, e disse que era para em um primeiro momento conhecermos como eram as coisas. Minha mãe ligou de volta e disse: “Cristina, pode ir". Eu fiquei surpresa, pois ela foi muito rápida na resposta, ela pensou tão rápido, e não foi um problema! Disse que sim, que eu podia vir.

Foi algo louco, muito rápido. Arrumei minhas coisas no mesmo dia, mas não tinha

\footnotetext{
${ }^{89}$ Associação Nacional Republicana - Partido Colorado (ANR-PC).
} 
dinheiro para passagem. E minha mãe me emprestou! No dia seguinte, acordamos de madrugada, e fomos ao terminal comprar a passagem, porque minha amiga já ia no dia seguinte.

Minha mãe me acompanhou, me pediu para me cuidar e disse que confiava em mim, que me acha preparada para a vida. Me desejou o melhor, e falou que era o momento para que eu colocasse em prática tudo o que ela me ensinou desde pequena, mas falou que eu também devia aprender com a vida, e que eu não iria me perder, se eu seguisse o que ela me ensinou.

Minha infância foi bem tranquila, graças a minha mãe, que sempre foi muito lutadora. Meu pai nos deixou, nunca esteve conosco. Ele nos visitava de vez em quando, mas não tenho recordação de um pai em casa, ele morava longe. Digo que minha mãe sempre foi pai e mãe.

Ela é uma lutadora, e ela quer que eu seja assim como ela, por isso recebeu tão bem esta minha oportunidade de morar fora do meu país, porque ela sabe que isso iria ser muito importante para a minha formação.

Como eu falei, no Paraguai tinha este problema por trabalho se não tem ligação com a política. E em casa, nós não ligávamos para a política. Mas desde que eu pisei no Brasil, eu me dei conta que a política é algo muito importante, e depois de cinco, seis meses aqui, estudei mais sobre o que é a política, e a partir daí me interessei bastante.

Sabe, São Paulo te faz mudar a visão, te mostra o que significa mesmo as coisas. No Paraguai as pessoas só pensam em trabalhar e estudar, estudar e trabalhar. É uma rotina dentro de um círculo, que não se tem melhoria. Ninguém pensa, por exemplo, o que mais a sociedade paraguaia precisa, o que as pessoas do interior necessitam para ter uma visão diferente, que queira lutar por direitos.

E desde que vim para cá tudo mudou em mim. E eu dou graças a Deus, e graças a minha mãe também por ter me dado esta oportunidade, de vir até aqui. Porque não é toda a família que quer que sua filha saia de casa. E eu tinha tudo lá, tinha uma casa, tinha onde dormir, roupas, estudos, tudo, mas eu queria algo diferente, algo para mim, algo que eu conseguisse por mim mesma. 
Meu dois irmãos mais velhos moram no Paraguai. O mais velho se casou e saiu de casa, já tem sua família, e mora perto da casa da minha mãe. O segundo, também casou, mas mora com minha mãe. Eu sou a terceira, saí de casa, estou trabalhando e estudando. E o meu irmão mais novo, de 19 anos, decidiu me seguir, e está aqui no Brasil. Minha mãe aprova tudo isso pois confia bastante na gente.

Quando decidi vir a São Paulo não contei para os meus irmãos, só para a minha mãe. Fiz isso porque ela é muito minha amiga, ela me entende em muitas coisas, então não era necessário contar para eles.

A mãe da minha mãe, minha avó, às vezes não entende porque estou aqui no Brasil. Ela sempre que me encontra me fala: "Cristina, você tem o seu país, tem que trabalhar aquil". E eu respondo: "Minha avó, eu sei, mas quero conhecer outro país, quer ver como é, para me desenvolver como pessoa, quero experimentar outras coisas, quero ver coisas diferentes, e quero conquistar coisas por mim mesma". E ela paciente responde: "tudo bem, minha filha, o que vamos fazer? Se você gosta, está bem”. Adoro minha avó! Ela vive umas duas horas de onde minha mãe vive, mas nos falávamos sempre por telefone.

E quando estava no Paraguai, eu fazia faculdade de enfermagem, como a minha mãe. Um dia estava na internet e minha amiga da igreja começou a falar comigo no chat. Ela me falou: “olha Cristina, vou para o Brasil, quer vir comigo?”. Eu até gostaria de ir, mas em nenhum momento eu tinha pensado em vir, não estava nos meus planos. Eu tinha pensado em me formar em enfermagem, conseguir um trabalho e pronto. Mas quando ela me falou que vinha, me deu uma emoção.... não sei, senti algo diferente. E por ela ser da igreja, minha mãe se sentiu mais segura.

\section{Assim que cruzei a fronteira percebi que havia muita diferença}

E esta minha amiga, que se chama Patrícia, era amiga de outro paraguaio que morava em São Paulo, o Leo. Eles se conheciam por internet apenas, mas a mãe dela é amiga da mãe dele, e as duas pediram para eles se encontrarem aqui em São Paulo. A Patrícia gostou da ideia e achou que era uma boa oportunidade para trabalhar ou estudar, ela não sabia o que queria. Nisso, ela me convidou também, e aceitei e assim viemos. 
E, resumindo, deixei a faculdade, amigos e família e vim. Estava com vontade de começar uma vida nova, e viemos sem ter nada certo! Eu mesma não tinha nenhum conhecido, eu vim atrás de minha amiga, que só conhecia o Leo. Eu fiquei preocupada porque ele a tinha convidado, e eu estava indo junto, mas ela falou que conversou com ele por internet, avisando da minha vinda. No entanto, ela falou no caminho que eu estava vindo com ela. O Leo ficou bravo, porque achou que a Patrícia tinha que ter avisado antes, porque ele disse que foi muito tarde que ela tinha avisado, e que ele já estava fazendo um favor para ela...

Viemos num ônibus de turismo, provavelmente clandestino, e desembarcamos em frente à agência El Sol, na Av. Rio Branco. Logo que desci do ônibus o Leo disse: "você é muito atrevida, Cristina!’. E eu fiquei um pouco mal, incomodada, no fim eu fui mesmo um pouco atrevida, eu quis vir, eu insisti com a Patrícia... Fiquei tão chateada pelo o que me falou, que até pensei em voltar para o Paraguai. Mas depois conversamos e ele disse que eu podia ficar, e me explicou que aqui o sistema de trabalho é diferente, que não pode ser tão oferecida com o tema do trabalho, que aqui as pessoas se aproveitam das outras, em muitos casos tem trabalho escravo. E eu não sabia nada disso, e eu estava tão deslumbrada que tudo o que me dizia entrava por uma orelha e saía por outra.

Assim que cruzei a fronteira percebi que havia muita diferença entre o Brasil e o Paraguai. Muitos dizem que não há diferença, mas em minha opinião tem muita! Ao cruzar a fronteira, apesar de não ser muito organizada a fronteira com o Brasil, é muito melhor que a de Ciudad del Este.

E assim que se cruza a fronteira veem-se jardins, e jardins mais limpos, as coisas são mais ordenadas, senti um ambiente diferente, um ambiente que eu gostaria que tivesse no Paraguai. Até os animais são diferentes, comparando com o Brasil, o pasto verde em que crescem, eu percebi tudo isso lá do ônibus. E de lá mesmo eu fiquei impressionada, pela dedicação ao trabalho, ao corpo e à alma, coisas que no Paraguai não se vê muitas vezes, ou pelo menos eu não pude ver lá o que eu vi no Brasil.

E quando eu cheguei em São Paulo, direto ao centro, na Av. Rio Branco, eu gostei muito da ordem que eu vi, do respeito ao pedestre, adorei isso. Eu falo para um amigo que aqui eu me sinto a rainha da rua, quando vou atravessar a rua me esperam, o que não acontece no Paraguai. 
E olha que engraçado, tive toda esta impressão na Av. Rio Branco! Adorei o correcorre do dia, da quantidade de gente, se você esbarra nas pessoas elas te pedem desculpas, são educadas, diferente dos paraguaios. Não se escuta lá um pedido de desculpas, a educação é diferente, a maneira de vestir, de falar... Mas tem outras coisas também iguais também, mas São Paulo demonstra que tem uma diferença marcante, e isso eu gostei demais.

Eu gostaria muito que lá no meu país, nos ônibus, as pessoas tivessem comodidade para se sentar, que o ônibus estivesse em bom estado, que fosse cômodo, que tivesse demarcado o lugar para pegá-lo, para descer...

Parece que aqui as pessoas são mais civilizadas. Lá, o ônibus no centro é bom, cômodo, mas faltam algumas coisas. Por exemplo, o motorista dirige e cobra, coisa que eu julgo ser muito arriscada. Os idosos, as crianças, não têm onde sentar, não têm lugar preferencial. Quer dizer, tem, mas ninguém respeita. Já no interior, os ônibus são totalmente um desastre, tratam a gente como animais, porque como a maioria das pessoas tem uma mente mais fechada, elas querem imitar as pessoas da sociedade de Assunção, mas não se importam com o seu próprio bairro. Em vez de reivindicar algo para melhorar, em vez de fazer uma manifestação, reclamar que alguma coisa não está bem, porque vive-se no coletivo, mas ninguém pensa nisso. Para ser sincera, o ônibus que leva para a cidade que minha família mora, nos faz parecer vacas. Lotado de gente, é um horror! E é o único meio de transporte. Se não se está com pressa pode-se caminhar, mas às vezes chove. E aí sim é um desastre... a estrada é asfaltada, mas não é bem-feita, então quando chove é um desastre, não limpam os terrenos baldios, encontramos ratos, baratas. Mas eu não ficava tão chocada quando morava lá, agora que vivo em outro país consigo perceber a diferença, a minha visão é outra. E agora vendo que em certas situações há tanto descaso, só pode ser culpa da política.

\section{Eu pensava que se eu passasse deste "teste”, eu podia passar por tudo}

Voltando a minha vinda para São Paulo, vim sem nenhum dinheiro. Não tinha nada, na verdade. Eu peguei um dinheiro emprestado da minha mãe para comprar a passagem, depois nos viramos. Lembro que falei: "Patrícia, não tenho dinheiro, como vamos fazer? Tenho medo de ser difícil ganhar dinheiro em São Paulo!’. E ela me respondeu para não me 
preocupar, que ela tinha um pouco de dinheiro. Ainda bem que ela estava bem tranquila, e graças a Deus nada nos aconteceu!

Nós fomos morar no apartamento do Leo, pois foi o combinado quando estavam em contato. Mas ele se ofereceu a nos ajudar por uma semana, mas depois de uma semana nós teríamos que encontrar um trabalho, uma casa, e como tínhamos só uma semana, tínhamos que ser bem rápidas.

E a sorte foi que logo encontramos, pois o Leo tinha contatos, então foi mais rápido. Eu comecei a trabalhar como ajudante geral em uma loja de coreanos, e a Patrícia trabalhou numa confecção com outras paraguaias.

E eu não me preocupei muito com a língua neste momento, pois a pessoa que me conseguiu o trabalho também era paraguaia, então ela me ajudava com a comunicação. E foi tudo tão rápido, e eu tive tanta sorte. $\mathrm{O}$ cargo que eu trabalhei era para ser da Patrícia, mas ela não quis. Ela acabou indo trabalhar como costureira. E ela sabia costurar, a maioria das moças no Paraguai sabe costurar. Eu mesma sei costurar, mas não profissionalmente. Costuro com máquina, mas daquelas mais velhas. Eu não sei costurar com overloque e todas estas outras coisas, é um pouco mais difícil, mas se me ensinarem, eu aprendo.

E assim foi a nossa vida em São Paulo. Achamos um apartamento com outra paraguaia, que nos alugou. A casa era bem grande, dividimos com ela. A comida foi um pouco difícil também, pois algumas vezes comíamos, outra não comíamos. E dormíamos em um colchão, as duas juntas. Foi duro. Teve vezes que eu chorei, porque eu me sentia sozinha, me questionava “o que estou fazendo aqui?". Mas eu não podia ficar assim, eu tinha que confiar em mim mesma, por mais que eu estivesse mal.

Era como se fosse uma prova para mim, uma prova que eu tinha que passar. Eu pensava que se eu passasse deste "teste", eu podia passar por tudo. E isso me fortaleceu. Pensava sempre no exemplo da minha família, da minha mãe, uma pessoa forte. Ela sempre me dizia que a vida não era fácil, que tinha que enfrentar o que viesse, e não é porque as coisas são difíceis que se tem que desistir e voltar para casa ficar atrás da mãe de novo. Ela sempre me falou que depende de nós mesmos que tudo saia bem, e eu sempre fui uma pessoa simples, humilde, me adapto fácil às coisas que passam pela vida, e assim que passei por esta fase. 
$\mathrm{Na}$ verdade, nunca foi um mar de rosas com a Patrícia. Tivemos uns desentendimento, ela disse que eu era egoísta, mas na verdade eu pensava num ensinamento da minha mãe, de ser independente. Sempre cada um em casa tinha suas próprias coisas, pasta de dente, escova de dente, toalha, sabonete. Ela dizia que a gente tinha que saber cozinhar, porque um dia íamos ser sozinhos, saber nos virar, nos defender na vida. Ela falava: "sou sua mãe, estou te ensinando a como viver a vida, todos somos passageiros nesta vida. Eu posso morrer, vocês têm que saber cozinhar, trabalhar, não importa se é mulher ou homem". Meus irmãos também sabem fazer de tudo.

E foi assim, eu sempre demonstrei para ela, então quando moramos juntas ela queria que eu fizesse compras para ela, que cozinhasse para ela, queria tudo para ela, mas eu não me criei assim. Eu ligava para a minha mãe e dizia o que tinha acontecido com a Patrícia, e minha mãe me falava para eu não me preocupar, que eu estava vivendo uma etapa nova da vida, que eu estava conhecendo a vida, conhecendo a minha amiga, e que tudo ia passar, que eu e minha amiga tínhamos criação diferente, e que tudo isso ia passar, mas que eu sempre ia ser a mesma pessoa de sempre. E eu não aguentava mais, ela queria mandar em mim, porque eu de vez em quando sou muito ingênua. Nós temos a mesma idade, mas ela queria que eu fizesse o que ela dizia.

Enfim, passou um tempo e eu, a Patrícia e o Leo mudamos. Conseguimos outro apartamento e fomos morar com uma boliviana no centro de São Paulo... e neste momento eu comecei a conhecer os bolivianos. E esta boliviana começou a se mostrar, ela queria ter todo o controle do apartamento. Ela tinha uma oficina de costura e quase não ficava em casa, e o pouco que ficava ela não limpava a casa, suas coisas, queria que eu fizesse tudo. Acho que se aproveitou que eu era muito tímida, calada, não defendia os meus direitos. E sempre havia discussões, ela gostava mais da Patrícia, porque ela sabia falar, não tinha vergonha de falar com as pessoas.

A Patrícia era mais aberta e eu muito mais introvertida. Eu sentia que a boliviana tinha algo contra mim. Ela me olhava com uma cara que não acreditava no que eu falava. Eu ficava no meu canto, somente ia trabalhar, e como eu gostei de São Paulo isso ficava mais fácil para mim, pois aqui é mais fácil conseguir emprego. Isso eu achava incrível, não é algo que acontece no Paraguai.

Se a pessoa procura trabalho no Paraguai sozinha, sem nenhuma indicação, nunca 
vão aceitá-la. Lá eles dizem que vão te chamar, mas nunca ligam. Esta foi uma das coisas que me fez mais gostar daqui, pois por mais que você seja estrangeiro, que não saiba falar a língua, te dão oportunidades. Por exemplo, eu fui ajudante geral, ganhava uns $\mathrm{R} \$ 600,00 \mathrm{e}$ quando saí do emprego, pagaram todos os meus direitos, mesmo com o pouco com que eu trabalhei, e ainda as férias, as horas extras. Davam almoço, café da manhã, coisa que não acontece no Paraguai. Eu me senti muito bem.

No começo eu não soube administrar muito bem o meu dinheiro, não soube economizar e às vezes não sobrava para o aluguel. Eu comprava as coisas que eu gostava, algumas guloseimas, e quando me dava conta, o dinheiro já tinha ido todo embora. Na verdade eu não sabia o valor de vinte, cinquenta reais, além de não saber como administrar bem o dinheiro. Eu pretendia mandar alguma coisa para a minha mãe, mas nunca sobrava. Eu queria mandar o dinheiro, mas ela disse que não precisava, apesar de eu saber que se mandasse ia ajudar. Ela me falou que eu não precisava mandar dinheiro, ela queria somente que eu soubesse como é a vida, queria que eu soubesse suportar as coisas que iam me acontecer. Queria que eu conhecesse as pessoas nas suas diferenças, trabalhos diferentes, tudo ia ser diferente. No fim, acho que o que ela queria mesmo era que eu ganhasse experiência de vida.

Ela disse: "eu não quero que me mande dinheiro, Cristina. Você sabe que eu trabalho aqui, ganho meu dinheiro. Se me falta alguma coisa eu faço algum trabalho extra para ganhar mais um pouco". E foi isso mesmo, desde pequena ela me ensinou a ser autossuficiente, e eu vendia salgados, tortas, salada de frutas, empanadas, desde muito pequena. E nunca tive vergonha de trabalhar, e eu e meus irmãos fomos criados assim. Meu irmão mais velho, nunca me esqueço, quando tinha treze anos, começou a trabalhar, e em seu primeiro salário, ele veio com uma bolsa cheia de brinquedos para a gente. Ele me deu uma boneca rosa! E para os meus irmãos trouxe bolas, para a minha mãe um cobertor.

\section{Minha mãe disse que eu vim para São Paulo só para conhecer o Leo}

Não canso de dizer que minha mãe nos ensinou a ser fortes, vou ser eternamente agradecida a ela. Ela sabe as condições que vivo no Brasil, que não tenho luxos, não tenho um lugar que seja meu, mas ela confia em mim. E este é meu segundo ano em São Paulo, e minha mãe continua confiando em mim. Este ano eu voltei ao Paraguai, e levei algumas 
coisas, uns presentes, um pouco de dinheiro, coisa que no ano passado não fiz, mas este ano eu consegui fazer, sobrou dinheiro, eu aprendi a administrar. E fiz questão de levar uns presentinhos, mas minha mãe não é materialista, ela é bem simples. E é o que eu quero ser, simples, não quero perder minha decência, quero ser trabalhadora, lutadora.

E quero estudar. Quero fazer ciências sociais, pois acho que é uma profissão que faria um bem para o Paraguai. Na verdade só tomei esta consciência quando conheci o Leo. E quando o conheci toda a minha vida mudou. Minha mãe brinca comigo dizendo que eu vim para São Paulo apenas para conhecer o Leo. E acho que pode ser, sabia? Quando eu morava no Paraguai não conhecia ninguém como ele. Todos os namorados que eu tive, ou os homens que eu conhecia, pareciam fracassados. Sentia falta de alguém que não pensasse só no momento, em aproveitar a vida. Eu queria alguém que pensasse no futuro, tivesse planos para cinco, dez anos.

Meu homem ideal era alguém que eu pudesse trocar ideias, que eu pudesse aprender. De repente que fosse um pouco mais inteligente que eu, ou que soubesse um pouco mais do que eu, para me estimular, sabe? E não queria um estrangeiro, brasileiro ou de outra nacionalidade. Queria alguém dedicado, que gostasse de estudar, de trabalhar, que não pensasse somente em dinheiro, mas que fosse lutador.

E eu fiquei muito tempo sozinha, sem namorado, ia da minha casa para o trabalho, do trabalho para a faculdade. Cheguei a trabalhar em um cyber e numa locadora. Como falei, no Paraguai não tem garantias trabalhistas, e então eu estava com raiva da vida, não queria saber nada dos paraguaios, apesar de ter tido um namorado, que era de classe média alta. Ele tinha tudo o que queria, sua família dava tudo para ele. Eu nunca gostei do jeito dele, era de uma família colorada, mesmo não entendendo nada de política nesta época, mas ficamos juntos por seis meses. Quando terminei, óbvio que não falei que não era pela política que não ia dar certo, mas que pensávamos diferente. Ele foi o meu único namorado que levei à minha casa para minha família conhecer. O Leo foi o meu segundo namorado oficial.

E foi a primeira pessoa que eu conheci no Brasil! E a Patrícia tinha se interessado por ele, então eu não o olhava com outros olhos, pela minha amiga e porque eu não tinha vindo para cá para buscar namorados. Mas o Leo no fim gostou de mim, e com o tempo eu também gostava dele, por ser honesto, lutador, estudioso, trabalhador, dedicado, coisa que 
eu não via em nenhuma outra pessoa. E eu vim com este pensamento do Paraguai, que não queria saber dos paraguaios!

Depois que eu o conheci, ele me demonstrou o lado bom dos paraguaios, me fez ver a força de se ter uma identidade, e isso me encantou! Talvez ele não seja o príncipe encantado que eu sonhava, mas ele é o que eu quero agora, ele é uma pessoa sincera, amorosa, trabalhadora, lutadora, te apoia quando precisa, por mais difícil que sejam as coisas.

E nós começamos a ajudar uns aos outros, e depois começamos a ficar juntos. E foi tudo muito rápido, isso tudo foi na primeira semana que estava aqui! Começamos a ficar juntos escondidos, não pela Patrícia, mas o Leo pensou que seria melhor não falar para ela logo de cara, porque ia ter muita fofoca, inveja, típico dos paraguaios. Até que uma noite saímos juntos para encontrar uma amiga e ela disse: “oi Leo, esta é a sua namorada?”. E ele respondeu: "sim, por quê?". E ela falou: “ah, ela é muito bonita para você”. E o Leo ficou super bravo! E ele respondeu para ela: "pelo menos é inteligente e está comigo!”.

E é verdade. Sinto que a maioria das paraguaias que vem ao Brasil querem casar, querem um homem que as mantenham, querem um homem lindo, que tenha dinheiro, somente para passar o tempo, ir a festas. Eu vim para cá com o objetivo de ter um trabalho, e quem sabe chegar mais longe e estudar. Na verdade este é o meu maior sonho, pois quando terminar de estudar minha meta é voltar ao Paraguai, com o Leo, e fazer algo muito bom. Quero melhorar meu país, é isso que queremos fazer.

\section{Pensei que teria que fazer alguma coisa para representar a minha cultura}

Eu fui me envolvendo sem querer com atividades políticas. Em 2011 fui à Marcha dos Imigrantes, e fiquei encantada, não sei por quê, mas fiquei muito emocionada, com todas aquelas diferentes culturas, da Bolívia, Peru, nacionalidades diferentes. Mas senti falta de uma maior representatividade do meu país. Eu perguntei para a Mercedes e para o Leo a razão do Paraguai não ter apresentado a sua cultura. Foi quando percebi que as pessoas que estão aqui não estão preocupadas em manter a sua cultura.

Pensei, no mesmo momento, que eu teria que fazer alguma coisa para que isso não 
acontecesse na marcha do ano seguinte. Para mim, era uma vergonha essa falta de representatividade. E pensei em fazer um grupo folclórico, um grupo de dança. Não imaginava de onde ia tirar as pessoas para dançar, mas de alguma forma eu ia conseguir. E foi assim que começamos a dançar, um grupo pequeno, com três garotas de Guarulhos, a Kátia, a Monica, a Silvia e eu.

Eu mesma nunca dancei, não sou profissional, mas sempre tive uma certa vontade de aprender a dançar, mas no meu país eu tinha outras prioridades, fora que não era uma preocupação reavivar as minhas raízes.

Inscrevemo-nos em um Projeto de Fomento da prefeitura, o VAI de dança, que nos ajudou muito para comprar as nossas roupas, ter dinheiro das passagens, ter dinheiro para um lanche. Ensaiávamos todos os finais de semana, fizemos apresentações, foi uma experiência muito linda.

Apresentamo-nos na praça dos paraguaios, na Barra Funda, fizemos apresentações em uma escola estadual. Fomos dançar também no local em que os grupos folclóricos de dança da Bolívia se apresentam, na verdade já dançamos várias vezes neste lugar. E a nossa última apresentação foi no final de 2012, na Marcha dos Imigrantes. Sempre foi o meu sonho nos apresentar lá e foi tudo perfeito, saiu como eu queria! Foi uma experiência muito linda.

E meu irmão mais novo estava estudando, lá no Paraguai, para ser professor de dança. Ele é bailarino, dança clássico, jazz e música paraguaia. Ele sabe dançar de tudo. E conversando com a Mercedes, uma brasileira que nos ajudava no projeto de dança, pensei em trazer o Marcos, meu irmão, para vir nos ajudar a ensaiar e estas coisas, e ela e o grupo acharam uma boa ideia. Ele ficou aqui por uma semana, e foram aulas intensivas. Ele fez a nossa coreografia. Na verdade ele substituiu a nossa professora que estava grávida.

Depois ele voltou em dezembro, antes da Marcha, mas para nos dirigir. Ele decidiu dançar com a gente também! Foi sua segunda vez aqui no Brasil, em São Paulo. Ele gostou muito daqui, muito por minha causa, mas muito por saber da importância de se manter a cultura de seu país natal. E para uma pessoa com talento, São Paulo oferece muitas oportunidades. E Marcos, meu irmão, se deu conta disso e resolveu vir para cá, e também quer estudar e fazer faculdade. E quer mais que tudo fazer o que gosta: dançar, coreografar, 
ter uma academia de dança. Nós não moramos juntos, mas nos vemos sempre, ele mora com um amigo, mas bem longe daqui do Bom Retiro, no bairro do Morumbi.

Lá no Paraguai ele não tinha muitas chances. Já estava há três anos dando aulas em uma academia e não tinha perspectivas de melhorar no emprego, melhorar o salário. E quando ele veio pela primeira vez para São Paulo, ele percebeu que aqui ele tinha alguma chance, tem diferentes oportunidades de trabalho. Ele sentiu como ou senti: aqui em São Paulo há muita promessa para a gente. Mas tem que querer prosperar aqui. As coisas não acontecem de mãos beijadas.

Parece que a gente sempre tem que ser ajudante ou encarregado de fazer alguma coisa para eles

Sobre os paraguaios em geral que vêm para cá, sinto que a maioria vem para trabalhar na costura. Normalmente eles são do interior, e não tiveram muitas oportunidades. São jovens que não terminaram o colégio, mas tem também uns mais velhos que não estudaram, e vêm para São Paulo viver da costura, ganhando pouco, mas o suficiente.

Trabalham para bolivianos, para os próprios paraguaios, para coreanos, e para brasileiros. E muitos, diferente dos bolivianos, não moram e trabalham na mesma casa. Muitos moram em cômodos alugados. Acho que muitos sofrem com a burocracia para tirar os documentos.

Como eu vim para cá e já conhecia patrícios meus que já estavam aqui há mais tempo, foi mais fácil para tirar os documentos. Foi tão rápido, que eu digo que São Paulo estava me esperando. Mas certamente não é o que acontece com a maioria dos imigrantes.

E como todos estes imigrantes, eu também trabalhei na costura. Foi em 2011, como cortadora de peças-piloto. Meu patrão era coreano, e não foi uma experiência muito boa.

Senti os coreanos muito autoritários, obviamente por terem mais possibilidades de serem patrões do que têm os paraguaios, de ter mais chances de terem uma loja, uma fábrica. Parece que a gente sempre tem que ser ajudante ou encarregado de fazer alguma coisa para eles. Alguns paraguaios têm a sua oficina, mas são muito poucos. 
E como não sabemos os nossos direitos trabalhistas, ou precisamos do dinheiro, temos que nos calar, temos que passar por humilhações, justamente por necessidade, para poder ter algum dinheiro para sobreviver. E para isso muitas vezes nos submetemos ao que pedem.

Eu cheguei a ser bem submissa a um coreano, foi realmente muito difícil, mas hoje acho que valeu como experiência, para saber como lidar com situações assim, para saber que eu tenho direitos. Nos próximos trabalhos não vou mais deixar ser assim, vou reclamar meus direitos de trabalhadora, de cidadã. Sei que muitas pessoas não pensam da mesma forma, vão pesar que precisam do dinheiro, que têm uma família para sustentar, que não é tão ruim como se diz...

Mas isso não é algo normal, se São Paulo tem leis, elas devem ser cumpridas. E como não foi justo o que os coreanos fizeram comigo! Eles não me davam razão, não me garantiram direitos, coisa que me entristeceu muito, e eu tive que suportar, pois precisava trabalhar para pagar o meu aluguel, minha comida e tudo mais. É muito triste esta dominação que os coreanos fazem, porque eles só querem produzir e produzir, não te dão liberdade para descansar, estar com sua família, saber o que se tem em São Paulo, a arte, a própria cidade. Eles não te dão oportunidade de ver o que mais existe na cidade, os imigrantes só conhecem o Bom Retiro, e perdem a oportunidade de serem pessoas. E assim o fazem para que outros tenham mais dinheiro, o que é triste de se constatar, mas assim é e fazemos de conta que não escutamos, e continuamos da mesma maneira.

Eu não pensava assim antes de passar por essa situação de submissão. Acho que no Paraguai eu estava cega, não sabia nada dos direitos, nada de política, então mais do que eu não sabia de nada, eu não queria saber de nada. A minha vida era só trabalhar e estudar, ir na igreja e somente isso. E não quero mais ser assim, quero fazer as coisas de uma forma diferente, algo que tenha sentido para a minha vida e para a das outras pessoas.

\section{Acho que agora ela pensa que eu sou uma revolucionária!}

E quero manter esta postura, não quero mais pensar que não tenho outra oportunidade, que tenho que me submeter ao que a sociedade diz, a forma de me vestir, ou que preciso ganhar dinheiro a qualquer custo. Agora sei que a essência da vida é ser 
humilde, ser simples, pois tudo o que temos um dia se vai, um dia vamos morrer e não vamos levar a nossa roupa ou o que compramos. E demorei para entender tudo isso, o que minha mãe ensinou. Agora sei que nunca podemos esquecer o que nossas mães nos ensinam.

E da última vez que estive com minha mãe ela, ela me falou com os olhos cheios de lágrimas: "Cristina eu estou muito orgulhosa de você, te vejo totalmente diferente, te vejo agora uma mulher que está buscando os seus rumos na vida. E vejo que está em uma vida boa, coisa que sempre quis para você" (lágrimas). E sinto que ela esta feliz, apesar de eu não ir mais a igreja (risadas).

Acho que agora ela pensa que eu sou uma revolucionária! E ela está feliz com isso! Ela sabe dos meus valores, e que eu aprendi o que ela a vida toda quis me ensinar, por tudo o que eu passei, e ela me disse que eu ainda vou passar por outras situações difíceis, ela falou que enquanto eu continuar viva eu vou passar por muitas coisas, e tudo é para o meu bem. Ela falou: "filha é tudo para o seu bem, para que você possa voar, você deve voar! Desde que saiba o que faz, que trabalhe, que faça o que goste. Mas lembre sempre de ajudar aos que necessitem”. E agora dou tanto valor a ela, pois ela, sobretudo, é uma mulher, uma mulher com garras, ela é a imagem que eu sempre fiz dela: uma mulher que nos deu casa, nos ensinou, nos cuidou, que nos mostrou coisas que temos que saber da vida... Coisas que muitas vezes quando somos adolescentes não queremos escutar, mas ela nunca desistiu! Minha mãe é uma heroína (lágrimas), e eu quero ser igual a ela, quero ser o melhor dela, quero formar a minha família! Mas tudo tem o seu tempo, primeiro quero me formar, nos estudos e como mulher. Quero ter um diploma e fazer o que ela sempre me falou: "Cristina, eu quero que você case, mas seu primeiro marido tem que ser o seu título" (risadas).

Ela sempre disse que eu podia me casar com quem eu quisesse, mas que primeiro eu tinha que acabar os estudos, para não ter que depender de ninguém, muito menos de um marido, por mais que ele te prometa um milhão de coisas, pois um dia o amor pode acabar, mas o seu diploma estará sempre contigo!

E vou prestar o vestibular o ano que vem. Quero primeiro ficar boa no português, depois vou estudar sociologia. Já estou até vendo isso, me disseram que no Tatuapé tem uma faculdade boa, sei que na Santa Cecília também.

Quero mostrar umas fotos. Tem esta foto comigo e com os meus irmãos. Ela também 
me deu uma imagem de Jesus Cristo, que eu deixo do lado da minha cama.

Tem outra, esta aqui, da minha mãe, com a minha idade hoje, e esta foto é a minha inspiração. Ela estava num congresso de enfermagem no Chile. Quando ela foi neste congresso eu tinha cinco anos de idade e eu sempre pedia para conhecer o mar. E ela falou: "Cristina, você só tem 5 anos e quer conhecer o mar. E agora eu vou ter a oportunidade de vê-lo". Então ela tirou esta foto dela na praia, e me deu!

E por isso que esta foto é minha inspiração! Pensei, "quando crescer vou ser como minha mãe, estudar, trabalhar, quero estar bem como ela!”. E ela sempre me lembrava: “eu vou te dar todas as portas para que possa estudar, possa viajar, para que você faça da vida o que quiser, e a primeira coisa é estudar. Na verdade estudando as portas vão se abrir para você, pois você vai conhecer as coisas da vida". Ela também crê muito em Deus, então sempre me pediu para confiar Nele, mas que tudo depende de mim. E é verdade.

E sobre a praia, a primeira vez que fui foi em novembro de 2012. Fui a São Vicente, que também é um lugar bem histórico para o Brasil. E tirei muitas fotos, e tirei uma no mar, para mandar para a minha mãe!

E tenho muitas fotos. Eu gosto muito de andar por São Paulo. No mês passado fui ao show do Calle 13, uma banda de Porto Rico. Sei que muitos imigrantes ficam nos lugares que estão a maioria dos imigrantes, como o caso do Areião para os paraguaios, ou a Kantuta para os bolivianos. Mas o Leo, meu namorado, tem uma mentalidade brasileira (risos). Eu sempre falo para ele que ele é brasileiro! E por isso gostamos de aproveitar a cidade. Tem outras duas pessoas que me influenciam bastante aqui no Brasil, o Humberto, que mora aqui há mais de 20 anos, e a Mercedes, uma brasileira, muito legal.

E não conviver só com paraguaios também me fez mudar bastante. E conhecer outros lugares, como por exemplo o Morumbi, comecei a gostar ainda mais da cidade! Quero viver em outro lugar, longe do Bom Retiro, porque é a forma que se tem de seguir adiante para a mudança. Eu gosto muito de conviver com os paraguaios, mas não se pode negar que tem picuinhas, fofocas, inveja, e aí tem sempre o sentimento que não gostam de ver progredindo. Mas eu sei que eles também têm que estar envolvidos na luta para progredir, melhorar. Eu os apoio cem por cento, mas temos que ter foco, e eu quero avançar mais, viver bem. Agora, por exemplo, a casa em que vivo não é minha, é alugada e divido 
com outro boliviano, mas sonho em ter um apartamento, para que eu possa receber a minha família, minha mãe, que eles saibam que tem um canto para eles, que podem dormir conosco, no nosso apartamento!

Mas já temos uma vantagem de não morar no mesmo lugar que trabalhamos. Eu falei para o Leo que este ano eu não quero trabalhar no Bom Retiro, quero trabalhar longe de casa. Quero um ano com muitos desafios, que eu possa falar melhor o português, quero me relacionar mais com a sociedade brasileira, quero conhecer mais brasileiros, jovens brasileiros, quero fazer amizades, conhecer mais a história brasileira.... não sei, quero ter uma mentalidade mais aberta, e implantar isso no Paraguai, eu sei que vai ser difícil, mas aos poucos, com minha família vou começar. Minha família, meus amigos... quero que eles vejam o Brasil de uma forma diferente, diferente até da imprensa, que mostra o Brasil como um país de mulheres peladas, que não gostam da igreja, que aqui é uma bagunça. Eu já cheguei a ouvir horrores quando voltei para o Paraguai! Me falaram: "nossa Cristina, como você consegue viver no Brasil, lá tem negros, as mulheres se vestem mal, e nem sequer vão à igreja, por que você gosta deste país?".

Eles pensam o pior do Brasil, principalmente quanto às mulheres. E eu tenho que explicar que eles só sabem daqui pelos olhos da imprensa, que às vezes é sensacionalista. E digo que eu também pensava assim de São Paulo, mas agora conheço a fundo, sei que é uma mínima parte de tudo. O que eu mais gostei de São Paulo é que tem oportunidade para o mais pobre, para aquele que tem o nível mais baixo, o que tem nível médio, nível alto. É por isso que eu gosto, e tem pouca discriminação..

E se meus patrícios souberem como é realmente São Paulo, eles vão ficar quietos, vão perceber como é aqui. Sinto que o Brasil passa por um momento muito bom, teve o Lula que eu gosto muito, gosto da sua história, e das oportunidades que ofereceu, não somente aos brasileiros, mas aos estrangeiros. Aqui também me ensinaram sobre o socialismo, lá no Paraguai quase não se escuta sobre o assunto, o que é fundamental!

E o meu país deu um passo muito grande para trás, com a volta dos Colorados ao poder. É uma lástima, pois ao invés da população saber mais sobre sua cultura, ou como realmente é o jogo do poder, não, fazem o que eles acham que se deva fazer. 


\subsection{Luzetânia Quino Flores}

Mas nós seguimos lutando e trabalhando

Meu nome é Luzetânia Quino Flores, nasci dia 12 de maio de 1980, na cidade de Trinidad, no Departamento de Beni. Somos em três irmãs, e eu sou a do meio.

Meu pai não morava junto com a gente, pois trabalhava no campo e nós vivíamos em um povoado. Ele trabalhava com madeira, era lenhador. Quase nunca o víamos. Minha mãe fazia comida para vender, mas eu e minha irmã nos criamos sós, porque minha mãe trabalhava em uma outra cidade. Nós vivíamos em Chapare, e eu e minha irmã ficávamos num colégio particular de freiras e minha mãe nos buscava a cada 15 dias.

Sempre que podíamos, desde pequenas, ajudávamos minha mãe a vender suas comidas. Ela fazia e nos mandava vender flan, pudim de arroz, pão, assados, bolos, torta, enfim, vários tipos de comidas.

Quando ficamos maiores, fomos viver com minha mãe em Ibigarsama, e lá não nos separamos mais. Meu pai continuou trabalhando com madeira, e minha mãe seguiu fazendo suas comidas. Houve um acidente nessa época em que voltamos a morar juntas, com minha irmã. Ela foi acender o forno a lenha e colocou muita gasolina, e quando riscou o fósforo, houve uma explosão que queimou todo o seu rosto. Ela tinha 15 anos e eu 10. Minha mãe se viu obrigada a vender a casa que tínhamos em um povoado chamado Chimoré para cuidar dos ferimentos da minha irmã.

Minha mãe não podia seguir fazendo comida para nós vendermos, porque minha irmã estava internada. Seu rosto estava enfaixado pelas queimações que tinha. Do seu pescoço para cima estava todo queimado. Mas nós seguimos lutando e trabalhando.

Eis que, enquanto arduamente seguíamos trabalhando, minha mãe nos apresentou o meu irmão. A história do meu irmão é outra desgraça que passou na vida da minha mãe. Ela em sua vida de solteira teve um filho, e quando ela se separou do pai dele, ele levou o seu filho, o meu irmão. Quando ele tinha 16 anos, ele saiu do quartel e foi à procura de minha mãe. Ela ficou tão feliz! 
Ele ficou um mês com a gente e nos ajudava a vender, enquanto minha mãe cuidava de minha irmã. Mas depois deste mês ele saiu de casa e foi trabalhar como lenhador, não com o meu pai.

E ele teve um acidente horrível onde trabalhava. O tronco da árvore caiu nele, e ele quebrou a coluna vertebral. Trouxeram ele por uma semana para a nossa casa, e depois o levaram a Santa Cruz, no Hospital San Juan de Dios, no mesmo hospital que minha irmã estava internada. Mas já não podiam operar e ele ficou em Ibigarsama, até o levarem de novo para La Paz, para operá-lo. O pai dele não quis ajudar, disse à minha mãe que ele já tinha criado meu irmão e que estava na hora dela ficar com ele.

Minha mãe tinha uma pequena poupança, e ela teve que investir tudo na operação do meu irmão. Ela queria comprar uma casa, ou ter uma loja, mas a operação do meu irmão era urgente.

E lá foi minha mãe para La Paz, e levou minha irmã mais velha que também precisava de cuidados, e eu fiquei com minha irmã menor. Meu pai nessa época ficou um pouco com a gente.

Porém, quando chegou a La Paz, os médicos disseram que nada podiam fazer e que ele ia ficar paralítico para sempre. Minha mãe e minha irmã já tinham voltado, e o hospital o mandou de volta para casa, sozinho!

O acidente foi sofrido, e o engraçado é que um mês depois que eu o conheci, ele sofreu esse acidente.

Adaptamos a casa para ele, minha mãe comprou um colchão especial de água que custou US\$600, comprou também muitos remédios. Tantas coisas teve que comprar para meu irmão! Ele tinha uma ferida nas costas e uma no quadril e essas feridas precisavam sarar. Não tínhamos como comprar uma cadeira de rodas.

Nós não sabíamos mais o que fazer, nós o levantávamos, o movimentávamos, dávamos banho, um paralítico sempre depende de uma pessoa. Nas costas, no lugar que ele caiu, se enchia de sangue, os seus pés e suas pernas inchavam, ele tinha muitas bolhas e feridas, e nós tínhamos que ter muito cuidado para levantá-lo. Às vezes doía muito quando o levantávamos, mas não fazíamos de propósito, nós não tínhamos experiência! Mas minha 
irmã chegou a frequentar um curso de enfermeira, enquanto eu trabalhava numa empresa de bananas.

Minha mãe demorou para acreditar que meu irmão não ia mais caminhar. Quando ela se deu conta, nós fomos pedir ajuda. Pedimos num centro juvenil de freiras, íamos à igreja e lá nos deram uma cadeira de rodas, e os padres e as freiras começaram a nos ajudar. Minha mãe tinha tanta preocupação, porque nós tínhamos que estudar! E éramos três filhas e um filho doente!

\section{Foi uma fase boa}

E nós não terminamos de estudar! E eu, com 18 anos, fugi de casa. Mas sempre ajudava a minha mãe, mandando dinheiro. Mesmo de longe mandava o necessário para o meu irmão. Fui viver em Cochabamba e lá fiquei grávida e tive minha filha, chamada Naye. Quando me separei do pai de Naye, estava já grávida da minha segunda filha. Minha mãe me dizia que ele não era tão responsável, ele viajava muito. Eu trabalhava na fábrica da Pepsi, em Cochabamba, e ele viajava para Chapare, onde minha mãe morava. E minha mãe o controlava, sabia o que fazia. Ele conheceu outra menina e minha mãe veio me buscar para voltar a morar com ela, e eu terminei com ele.

Estava grávida de minha segunda filha e não voltei mais. Mas minha mãe me disse "agora você tem suas responsabilidades, tem suas filhas, não pode só sair para me ajudar a vender". Então fui buscar trabalho em uma empresa que estava construindo uma estrada. Consegui um trabalho de lavadeira.

E lavava 15 dezenas de roupas diariamente. Minha mãe também trabalhava nessa empresa, fora as vendas das comidas. E nós lavávamos, eu lavava, e nessa época nem tínhamos luz, nem água porque no nosso povoado não tinha nada disso. Íamos até ao rio, era muito difícil para a gente. E era longe! Quando voltava tinha que estender a roupa, esperar secar e passar, num ferro pequenininho que eu tinha. Eu esquentava o carvão na cozinha e passava as roupas. Esse ferro eu ganhei de presente de uma senhora velhinha de Puerto Villareal, e eu tenho guardado até hoje!

Eu passava as roupas até meia noite, uma da manhã. E no dia seguinte tinha que 
entregar toda a roupa e pegar mais para lavar. Era assim, entregava e recolhia, entregava e recolhia. Eu até que ganhava bem, me pagavam $\mathrm{B} \$ 15^{90}$ por dezena, mas tinha que ser lavado e passado. E eu e minha mãe seguimos trabalhando assim até que terminaram de construir a estrada.

Foi uma fase boa, meu pai trabalhou na estrada também, cuidando das máquinas. Depois disso minha irmã mais velha, com seu esposo, se mudou para Sucre. E ela se recuperou das queimaduras, ela não tem nenhuma mancha no rosto! Tem algumas cicatrizes, mas os padres e irmãs que cuidaram dela passaram uns cremes que vieram da Itália e seu rosto ficou ótimo. Mas estes cremes eram caríssimos. Mas minha irmã sarou bem. Quem nunca ficou bem foi o meu irmão.

Mas o pai dele o levou junto com sua madrasta, em Guayaramerín, porque minha mãe não podia mais pagar as contas. E eu fui para Cochabamba. Depois de um tempo, minha mãe me pediu um favor, que eu trouxesse meu irmão de volta pra casa. Meu irmão devia se sentir muito mal por não caminhar. Mas com seus ferimentos ele nunca ia poder caminhar. E meu irmão tomou uma decisão: queria vir ao Brasil! Ele se tornou evangélico e seus irmãos da igreja disseram que podiam ajudá-lo no Brasil, em São Paulo, aqui nessas igrejas grandes.

E eu o levei ao Brasil. O trouxe de Trinidad. Fomos de Ibigarsama até Santa Cruz, de Santa Cruz até Trinidad, e de Trinidad pegamos um avião para São Paulo.

E viemos de avião! Nos custou caro muito, muito! Não nos custou muito de Santa Cruz até Trinidad, mas de Trinidad para São Paulo nos custou muito! Tive que pedir ajuda na prefeitura de Trinidad, tive que preencher muitos papéis! E nos ajudaram com uma passagem. A outra tivemos que pagar, custou B $\$ 2000$, o que acredito ser uns US\$800, enfim, era muito dinheiro!

Eu tinha vinte anos, e como era a nossa primeira vez viajando de avião, ficamos com medo! Eu segurei no meu irmão, e como ele não sentia as pernas, ele agarrou minha cabeça!

Minhas filhas ficaram com minha mãe. E essa viagem toda foi boa porque eu pude conhecer a minha avó, que morava em Trinidad. Eu não conhecia a família da minha mãe e nem do meu pai. Somente eu e meu irmão conhecemos a minha avó. Minha mãe se separou

\footnotetext{
${ }^{90}$ A moeda corrente da Bolívia é o Boliviano, que aqui vamos representar como "B\$".
} 
de sua família. E foi bonito conhecê-la.

E nós viemos para o Brasil. Meu irmão veio porque os "irmãos" da igreja o trouxeram, ele virou professor, técnico das crianças em cadeira de rodas. Ele gostava de jogar bola, então o contrataram, ele ganhava salário. E eu só o trouxe até aqui, até o aeroporto. Não soube exatamente para onde ele foi. Os irmãos da igreja vieram e o levaram. Quando nos despedimos ele disse “eu me vou, irmãzinha. Nós nunca mais vamos nos ver". E foi verdade, nós nunca mais nos vimos, ele nunca mais voltou. Foi triste, nos abraçamos, eu me lembro que nos abraçamos, e eu me despedi, pois o avião já ia voltar para Bolívia.

Já de volta, passaram-se alguns meses, ou um ano, e eu saí de casa de novo. Fui para Cochabamba. Minha mãe ficou em Ibigarsama, minha irmã com seu marido foram para Santa Cruz, a outra irmã vivia em Sucre. Ou seja, cada uma foi viver a sua vida. Mas minha irmã menor brigava muito com o seu marido, ele a fazia sofrer demais, a maltratava, ele era malcriado. Minha mãe então decidiu viver em Santa Cruz com ela, meu pai foi também. Mas precisava de alguém para ficar na nossa casa em Ibigarsama, então eu saí de Cochabamba e fui para lá.

Nessa época minha filha maior entrou na escola, e eu não tinha mais ninguém para me ajudar. Então eu comecei a trabalhar. O bom que não precisava pagar aluguel, só luz e água. Mas tinha as coisas das minhas filhas também. E eu comecei a vender comida, igual minha mãe. Fazia flan, pudim de arroz, pão, majadito, locro e vendia no meu carrinho. Meu pai me deixou um carrinho para vender. Então eu saía com o carrinho e minhas filhinhas atrás de mim! Vendíamos onde minha mãe vendia.

Quando passou um ano fui visitar a minha mãe em Santa Cruz. Eu, minha bebê e minha outra filha que já estava grande. Lá cheguei à conclusão que eu queria morar lá em Santa Cruz, pois lá eles tinham a possibilidade de me ajudar. Mas eu não sabia como eram as coisas com o meu cunhado. Eu não o conhecia! Minha irmã ficou feliz em me ver, me apresentou ao meu cunhado. Depois de duas semanas lá, fui me dando conta da situação.

Minha mãe tinha o seu quarto separado da minha irmã, mas as duas que pagavam pela casa. Minha mãe disse que não estava gostando de ficar lá, que queria voltar. Eu também não entendia porque ela tinha ido morar lá, sendo que ela tinha uma casa e lá tinha que pagar aluguel. E era difícil ter o que comer lá, não tinha nem banana, na cidade, tudo era 
dinheiro, tem que ir de carro, moto, porque tudo é longe... E eu disse para ela: "Vamos voltar, mãe!". Mas ela disse que minha irmã sofria muito com o marido, e disse que ia ficar, mas sugeriu que eu alugasse um quarto de nossa casa, e que mandasse o dinheiro para ela.

\section{Eu me assustei}

Passou outro ano, e minha mãe foi nos visitar em Ibigarsama. Ela estava um pouco mal de saúde, me dizia que se sentia mal, e eu percebi, ela não comia, estava fraca. Ela falava que tudo doía, mas eu não dei muita importância. E seguia vendendo minhas comidas, fiquei bem conhecida no povoado. Eu disse para a minha mãe que estava vendendo cuñape e ela foi vender comigo. Dizia a todos: “minha mãe chegou de Santa Cruz!”. E ela seguia reclamando de dor, então resolvi falar com o médico, o Dr. José Luis.

Eu falei para ele que minha mãe estava mal, com hemorragia, e não podia ser menstruação, porque minha mãe tinha 55 anos. Ele pediu para eu levá-la para ele ver, e eu a levei. Ele perguntou para ela o que estava acontecendo e ela mostrou onde doía. O doutor me chamou de lado e disse que sabia o que era. Eu falei "doutor, por favor não me diga o que eu estou pensando! Por favor, não fale na frente dela, diga só para mim”.

Então eu pedi para ela ir comprar um remédio que eu queria falar com o médico sobre a Naveli, minha filha, já que o doutor tratava da família toda. Ele era compreensivo, nos deixava pagar em prestações. E ele disse que tínhamos que ir ao hospital geral, minha mãe tinha que fazer o Papanicolau e outros exames, mas que eu devia procurar a Doutora Sanchez. E eu fui, naquele momento mesmo, fui ao hospital, falei com a doutora, disse que minha mãe estava mal, mas ela falou que não podia atender naquele momento, pediu para voltar no dia seguinte no primeiro horário, sem que ela tomasse café da manhã.

Minha mãe não queria ir, mas eu insisti e fomos. Quando a doutora disse que devíamos levá-la para a cidade urgente, eu me assustei. Não sabia o que dizer a minha mãe, nem as minhas irmãs, nem ao meu pai. Cheguei em casa um pouco triste, e fui fazer as comidas para vender, mas antes fui no mercado, depois fiz majadito e fui vender. Na volta, chegaram umas senhoras para me levarem ao banco para eu pegar crédito. Como elas sabiam e viam que eu trabalhava, queriam de alguma forma me ajudar. Foram comigo em casa, e levaram minha identidade para fotocopiar. Insistiram para eu pegar o dinheiro, e eu 
peguei $\mathrm{B} \$ 3$ mil.

Com esse dinheiro peguei minha mãe e saímos de Ibigarsama, fomos à cidade, onde me falaram que era melhor, e gastei todo o dinheiro com exames, análises. Era tudo muito caro, um custava $\mathrm{B} \$ 600$, outro $\mathrm{B} \$ 700$. Não existe saúde pública na Bolívia, tudo tem que pagar. Depois do último exame que fez, que custou $B \$ 450$, eu soube que minha mãe tinha câncer no ovário.

E eu não queria que os doutores falassem para ela, porque eu sabia que ela não ia aguentar. E eu fiquei um mês com minha mãe em Cochabamba, e nesse mês eu precisava ter dinheiro para o transporte, na verdade eram sempre duas passagens, para mim e para ela, de ida e volta, para fazer a quimioterapia, a radioterapia. E pelo tratamento eram B $\$ 12$ mil. Eu fui até a assistente social do hospital e pedi um desconto, ou uma ajuda mesmo, ou que me ajudasse pelo menos com os medicamentos. E apesar da assistente social ter me prometido que ia ajudar, ela não ajudou. E eu também tinha que ter dinheiro para as receitas, que não eram baratas, era mais de $\mathrm{B} \$ 200$ cada receita.

Tive que chamar meu pai e dizer: “pai, a mamãe está mal”. Ele pediu para voltarmos. Mas eu insisti, disse que era melhor ficarmos na cidade, porque ela estava melhor nas mãos dos médicos, mas ele insistiu e disse que não tínhamos dinheiro. E eu precisava voltar para pagar a parcela do meu empréstimo do banco, senão não iam me dar as outras parcelas. De modo que deixei minha mãe sozinha por um mês, e voltei a Ibigarsama, onde me pus a trabalhar de manhã, de tarde e de noite, de manhã, de tarde e de noite.

Minha irmã ajudava vendendo hambúrguer. Ela voltou para Ibigarsama, trouxe um carrinho de Sucre. Só que ela vivia em uma casa à parte. E vendíamos os hambúrgueres perto de uma discoteca, ela ficava de noite e eu saía vendendo de dia. Eu fazia qualquer coisa para vender, e mandar dinheiro para a minha mãe para os seus remédios, e para o meu pai e para as minhas filhas. Assim, quando minha outra irmã imaginou que minha mãe estava mal, ela veio com o seu marido, de Santa Cruz até Ibigarsama. E de repente estávamos nós três unidas de novo.

E eu chamei as duas e perguntei: “o que vamos fazer com a mamãe?”. E Naryi disse que não podia viajar, Nayely também não, então eu fui buscá-la, mas ela queria ir a Santa Cruz, e eu a convenci a voltar para casa. E nós seguimos lutando para sobreviver, minha 
mãe mesmo doente continuou vendendo suas comidas.

Nós nunca falamos que o que ela tinha era câncer. Ela perguntava e eu dizia que era a vesícula dela, que estava a ponto de estourar. Ela nunca se abateu pela doença, e dizia que ia sarar, que ia seguir adiante! E assim fazia suas coisinhas para vender.

E meu pai parou de trabalhar como lenhador, foi cuidar de vacas, iam dar um salário de B \$1 mil. E minha mãe estava um pouco melhor e foi com ele, meu pai já estava velhinho, e foram os dois velhinhos!

E me deixaram sozinha de novo, e nesse meio tempo tive outro filho, eu não tinha namorado, minha mãe ficou um pouco chateada, e eu disse que eu podia ir embora, e ela disse que não, que os filhos não vêm para sofrer, e dizia: "olhe você e suas irmãs, por tudo o que passamos, e vocês ainda terminaram os estudos". E era verdade, nós terminamos de estudar, e quando terminamos, ela nos matriculou em um instituto de costura, eu e minha irmã mais velha.

E quando nasceu meu filho, minha mãe voltou a morar comigo, e eu continuei vendendo minhas comidinhas, e eu queria ganhar mais dinheiro, porque minha casa era de madeira, e sempre chovia e a casa alagava. Os pais de meus filhos não me ajudavam, e eu nem fui atrás deles para pedir pensão, porque quero ser sozinha, não preciso de homem nenhum.

\section{"Luze, não temos dinheiro para os remédios"}

Mas desta vez que minha mãe foi morar comigo, as dores dela voltaram, e mais fortes! Foi aí que uma médica de Santa Cruz disse que ia curar a minha mãe, e eu acreditava nela, sabe? Era uma clínica particular e eu deixei a minha mãe internada lá, eu acreditei na médica, sabe? E era melhor, porque eu já tinha três filhos, a mais velha estava na escola, e eu era responsável por eles, e me sentia responsável também pelos meus pais. Então tive que deixá-la na clínica e voltei a trabalhar. Precisava pegar mais dinheiro emprestado, aquele eu tinha devolvido sem problemas.

Desta vez eu peguei $\mathrm{B} \$ 6$ mil. E a primeira coisa que fiz foi sair para comprar 
comida, porque minha mãe estava voltando. Comprei arroz, açúcar, azeite, sal. Carne eu não comprava mais, pois não tinha mais geladeira. E quando voltei do mercado, minha mãe já havia chegado. Ela estava mal, com as veias amarelas... Eu perguntei o que ela tinha, a coloquei sentada e ela falou: "filha, eu sei que vou morrer, vocês não querem me falar isso" e eu dizia que não, que ela ia viver, que o problema era a gastrite, a vesícula. Dizíamos sempre outra coisa, mas ela não acreditava, ela queria saber a verdade, mas nós, nem eu nem minhas irmãs, nós nunca falamos a verdade.

Ao meu pai nós contamos, uma vez fizemos uma reunião familiar com ele e dissemos que a mamãe tinha câncer no útero, e que o médico disse que não se podia fazer nada. Só sabemos que ela vai nos deixar, mas não sabemos quando. Disse: "temos que ser fortes papai”. E ele não se deu por vencido, dizia para levá-la para lá, levá-la para cá, e a levamos a uma clínica particular em Montero. Minha irmã menor e meu pai ficaram com ela, e Naryi me dizia: “Luze, não temos dinheiro para os remédios". Não tínhamos mais de onde arranjar dinheiro. Nós achávamos que ela ia sarar, mas ela nunca sarava. Nós três pegávamos dinheiro emprestado, já devíamos muito dinheiro. E quem mais dava dinheiro era eu e meu pai.

E lá em Montero ela ficou um tempo, e melhorou um pouco, e seguia lutando por sua vida. E quando ela voltava, nós íamos vender as comidas juntas, mas cada um com suas coisas, porque ela já estava velha e não queria saber de vender hambúrgueres e essas coisas, queria vender suas coisas tradicionais.

Eu saía para vender de manhã, voltava ao meio-dia, cozinhava mais um pouco das duas da tarde até as seis, e depois saía das seis até uma da manhã. De manhã começava tudo de novo. Era muito cansativo. Mas eu aproveitava quando chegavam as pessoas, nos ônibus de viagem. Meus filhos ficavam na escola ou junto comigo. $\mathrm{Na}$ verdade as meninas estudavam de manhã, e à tarde a mais velha me ajudava a cuidar do seu irmãozinho. Ela praticamente o criou como filho dela, dava mamadeira, brincava, porque eu não parava em casa, era muito trabalho.

Então minha mãe ficou muito, muito, muito mal. E nós já tínhamos terminado de pagar a nossa outra dívida, de B $\$ 6$ mil, eu paguei, na minha luta diária, paguei centavo por centavo. E de repente aparecem aquelas senhoras que me emprestaram o dinheiro. Elas queriam que eu pegasse mais dinheiro e eu disse que agora não podia, que já tinha muitos 
gastos, duas filhas na escola, minha mãe doente, eu sozinha não posso pagar, disse. E elas insistiram, falaram que eu poderia pegar mais $\mathrm{B} \$ 6$ mil, e eu disse que se eu fosse pegar, eu precisaria de B\$12 mil. E elas falaram que dobrariam, que eu poderia pagar, se já o fiz com minha mãe doente e minhas filhas para sustentar. Elas me convenceram, mas eu peguei a mesma quantidade, $\mathrm{B} \$ 6$ mil.

Aí sim minha mãe ficou mal, parece que adivinhou que eu peguei o dinheiro. E ela ficou de cama. E eu não sabia o que fazer, mas tinha dinheiro agora. Mas eu não podia levar minha mãe para a cidade, pedi para minha irmã mais nova. Eu dei B $\$ 3$ mil para ela para que ficassem em Santa Cruz e fiquei com a outra metade, para o meu negócio. Mas elas foram para Cochabamba. Minha irmã não fazia nada sem falar comigo, e eu tendo que trabalhar. Me sentia esgotada.

E eu pressionava minhas filhas (choro). Minha filha tinha oito anos, a outra tinha cinco, e eu as pedia para me ajudar, e elas me ajudavam, vendiam refresco, ganhavam $\mathrm{B} \$ 21$ ! E elas me davam (choro). Elas tinham seu próprio negócio, comprovam frutas, limão, laranja, compravam açúcar. Ela com oito anos tinha o seu negócio e eu o meu, ela contava o seu dinheiro, e eu o meu. E ela gostava de vender. Às vezes ia comigo, às vezes eu pedia para ela cuidar do seu irmãozinho. Eu dizia: “quem vai cuidar do seu irmão?” e ela: “eu vou, mamãe!”.

Muitas vezes o meu pai chegava com um peixe, ele pescava quando minha mãe precisava por causa dos remédios. Minha mãe me chamava e falava que não era para a gente gastar muito dinheiro, e ela queria sair para ir ajudar. Mas ela não conseguia, era muito forte a dor, ela às vezes gritava na cama, e a gente olhava e não sabia o que fazer. Sentíamo-nos impotentes de não poder ajudar, eu me sentia impotente de não ajudar minha mãe. E minha mãe ficou uns três anos de cama, nós sofremos muito.

Nós tínhamos um grupo de pasanaco, ${ }^{91}$ em que a Rosa, com quem eu trabalhei aqui no Brasil, também participava. Nós pagávamos mensalmente B \$75. Eu tinha um número, minha mãe também, e minha irmã dois números. E nós queríamos esse dinheiro para pagar o banco, mas minha mãe queria pegar esse dinheiro para fazer a casa dela. Ela estava enferma mas pensava na casa, porque em seu pensamento ela queria me deixar o dinheiro e uma loja.

\footnotetext{
${ }^{91}$ Pasanaco é considerado um jogo, uma espécie de consórcio, onde os participantes mensalmente depositam um valor pré-estipulado, e o valor total é sorteado por mês entre os participantes.
} 
Ela não queria que eu sofresse (choro), como eu era mãe solteira, na época tinha três filhos, trabalhava tanto... era esse o seu pensamento.

Foi quando precisávamos do dinheiro e fui procurar a Rosa. E ela tinha desaparecido de Ibigarsama! Com o dinheiro! Creio que depois disso minha mãe piorou mais ainda. Ninguém sabia da Rosa, nem a sua família, sua mãe, que também chamava Rosa, sua avó. Eu fui até a casa dela, disse que minha mãe precisava do dinheiro, que tava doente, pedi por favor, implorando, disse que meu pai também precisava, que os dois estavam velhinhos. Queríamos recuperar o dinheiro de minha mãe, e não pudemos. Bom, passou um tempo, nos falaram que Rosa tinha ido buscar a sua avó, D. Pura, e eu falei: “mãe, quem sabe ela está com o nosso dinheiro?”. E minha mãe precisava do dinheiro, ela precisava de fraldas descartáveis, nós precisávamos de dinheiro, porque às vezes tinha reunião na escola e eu perdia a manhã toda, não dava tempo de preparar minhas coisas para vender...

Então fui buscar a Rosa na casa da D. Pura, mas ela já tinha saído. Perguntei para a D. Pura se ela tinha me deixado dinheiro, e ela disse que uns B $\$ 700$. Mas era uma quantia que já ajudava. Minha mãe pegou esse dinheiro e falou: "pronto, vou ao médico agora, tenho meu dinheirinho". E fui atrás do Dr. Jose Luis, falei que ele é que era o médico da minha mãe. E ele deu uns remédios que passavam a dor somente. E ela não sentia mais quando urinava, a sua barriga inchava... às vezes ela chorava, acordava de madrugada, não sabíamos o que fazer... Parecia um bebê, porque tínhamos que trocá-la, dar banho... Na verdade era mais um bebê na casa.

Passaram-se dois anos, assim com fraldas, sofrendo, mas as pessoas que a gente conhecia sempre iam nos visitar, e davam de presente $\mathrm{B} \$ 5$, algumas fraldas descartáveis, alguns traziam leite. Mas às vezes eu falava para o doutor me dizer a realidade, quanto tempo ela tinha de vida, ela estava sofrendo muito, às vezes queria que Deus a levasse (choro).

Sentia-me muito mal em não poder fazer nada, em vê-la sofrendo. Chegamos a comprar uns comprimidos muito fortes para dor, acho que com morfina. Precisávamos drogá-la para não sentir dor. Mas não fazia efeito. Então tivemos que interná-la de novo.

Mas o fizemos no hospital de Ibigarsama mesmo. A internamos no dia 10 de agosto, e ela saiu no dia 15 de agosto, ficou uma semana. E ela estava inchando muito, já não podia 
caminhar. O médico disse que tínhamos que levá-la para Cochabamba ou Santa Cruz, mas não falava que ela estava em seus últimos dias. E só nessa internação a conta deu B\$5 mil! Muito caro, fora os medicamentos, dando um total de B\$6 mil.

$\mathrm{Eu}$ e minhas irmãs não sabíamos o que fazer, se não tivéssemos pelo menos a metade, não poderíamos levá-la. Então fomos de novo atrás da Rosa, para que ela nos desse uma parte do dinheiro, que era B $\$ 4$ mil que ela devia a minha mãe. Não a encontramos, então fomos atrás das outras pessoas para que nos pagassem, ou nos ajudassem pelo menos, mas ninguém nos ajudou. Quer dizer, nos ajudavam com cinco, dez, mas estava longe de alcançar o valor que precisávamos. Conseguimos juntar B $\$ 2$ mil. Com esse dinheiro imploramos para o diretor do hospital para nos deixar levar a nossa mãe, e conseguimos, mas levamos para minha casa, e ela passou uma semana muito bem, até corria, que incrível, brincava com os netos! Fiquei tão feliz, achávamos que ela tinha sarado, era tão bom ver minha mãe feliz assim! Meu pai também estava feliz!

\section{Enfim, continuamos a viver}

Eu lembro como se fosse ontem quando eu falei: "mãezinha, tenho uma reunião na escola, vou deixar a minha filha com você. Não vou demorar muito", e ela disse: "tudo bem". Eu já tinha deixado a sopinha dela, e meu pai ia dar. Mas quando voltei da escola, minha mãe já estava mal, estava muito fria, segurava a sua mão, estava gelada, eu perguntei se ela estava com frio, e ela dizia que não, eu perguntava o que ela tinha, e ela respondeu: "nada, nada", e eu dei a sopa para ela, como se ela fosse um bebê, ela não queria comer, eu perguntando o que ela tinha, e ela seguia dizendo que estava bem. Então eu fui fazer majadito para vender, porque era o prato que mais se vendia, e ela inclusive me ajudou a descascar ervilhas, me ajudou a cortar o frango, eu cozinhei até as cinco da tarde e depois sai para vender. Disse: "mãe estou saindo para vender" e ela respondeu "sim minha filha, vá bem!", e foram as últimas palavras que eu ouvi saindo de sua boca...

E eu falei para a minha filha antes de sair para vender: "a vovó sempre precisa de um copo de água e um penico", mas na casa também estava o meu pai, minhas duas irmãs. E minha mãe recebeu uma ligação de Trinidad, da minha avó e da minha tia que falaram para ela ir para lá, que minha avó queria ver minha mãe. E ela falou com elas, e ficou feliz, e ficou fazendo planos para ir, meu pai tinha vendido um porco e ganhado $\mathrm{B} \$ 800$, tinham 
dinheiro para ir!

E eram umas 6 da tarde, eu estava vendendo dois pratos e me deu um mal-estar, pensei que fosse desmaiar, a senhora de uma loja trouxe um copo de água, eu não sabia o que eu tinha. E continuei vendendo, mas não conseguia pensar em nada, e meu cunhado foi me buscar, ele falou que minha mãe tinha morrido, e eu não acreditei, o chamei de mentiroso, não conseguia acreditar, achava que ele estava mentindo, e voltei para casa e minha mãe tinha falecido. Eu não sabia que minha mãe tinha morrido, mas eu senti!

Cheguei em casa e minhas filhas estavam chorando, e elas falaram: "a vovó morreu mamãe. Ela se foi e não vai voltar nunca mais”. E eu não acreditava! Entrei em casa e minha mãe estava deitada na cama dela, ela parecia que estava dormindo, e eu bati na barriga dela, "acorda mãe, acorda mãe", a barriga dela ainda estava quente, e meu pai falava que ela estava morta, eu gritava o seu nome, dizia não se vá, não se vá, eu fui buscar o médico e disse para ele que minha mãe estava desmaiada, ele foi vê-la, mas realmente ela tinha morrido.

E começou a chegar gente, minha irmã foi ver o caixão, e eu não sabia por onde começar, as pessoas chegando, tinha que arrumar uma tenda, porque chovia, e eram onze da noite e as pessoas iam chegando com suas velas, flores, era tanta gente!

E eu tinha que fazer alguma coisa, eu sempre fui a pessoa da família que tomava as atitudes, todo mundo esperava isso, até o meu pai. E no velório da minha mãe não foi diferente, uma irmã foi atrás do caixão, a outra atrás das cadeiras. Era como organizar uma festa. Mas eu estava tão triste! E o doutor deu um calmante para mim e para o meu pai, que sofria do coração.

E tinha tanta gente no velório, eu não imaginava, porque minha mãe era um pouco chatinha, mas era muito conhecida, era vendedora de comida fazia um tempão. Tivemos a ideia de colocar uma caixinha para que as pessoas pudessem nos ajudar. E tínhamos que contratar um carro para que levasse o caixão até o cemitério. Mas não podíamos usar o dinheiro da caixinha, porque a gente tinha tantos gastos. Então pedimos para uns açougueiros que nos ajudaram com o caminhão do açougue a levar as pessoas, e nós fomos com outro carro. E passou o velório, passou o enterro e as contas continuaram. Tínhamos que pagar o hospital, uns $\mathrm{B} \$ 4$ mil, o caixão que era $B \$ 4600$, muito caro. Nossa família fez 
uma reunião e vimos que conseguimos juntar $B \$ 2100$. Meu pai falou para pagarmos o caixão, mas era a metade do preço! Então conseguimos negociar para pagar a prazo, então demos B \$1000 para o hospital e B \$1000 para o caixão.

Enfim, continuamos a viver. Agora não dava mais para brigar com minha mãe para sair e vender, eu tinha que sair para vender sozinha, e assim se foi a minha vida, mais triste... quando eu saía para vender e minha mãe estava doente, pelo menos ela cuidava dos meus filhos, se eu me demorava, sabia que ela estava com eles, tinha um adulto com eles.

Agora, eu tinha que sair bem cedo pra vender, deixava as crianças na escola, tinha que buscá-las, deixava o meu bebê, às vezes ele ia comigo, tinha 3 anos. Mas é difícil sair para vender com o bebê. Às vezes o deixava em casa sozinho. Tinha que ser assim, que triste... mas aí eu vendia super rápido, cozinhava, ia vender, e cozinhava outra vez. Mudou todo o esquema, nem mais as minhas irmãs me ajudavam. Quer dizer, claro que ajudavam, mas elas também tinham que conseguir dinheiro. Eu tinha dado a ideia de minha irmã vir cozinhar em casa, porque eu morava mais perto da cidade, aí meus três sobrinhos podiam ficar juntos com os três meus filhos, mas eles brigavam muito! Então não deu certo.

Mas nós continuávamos trabalhando, e já não se vendia muito, os produtos subiram de preço, não havia mais muita venda. Não dava mais para vender as coisas por B \$10, tinha que ser $\mathrm{B} \$ 12$.

E eu tinha muitas contas, para mim que era sozinha, era muito gasto, e até me cortaram a luz, a água, não podia pagar mais. E eu devia para o banco, ao hospital, à funerária. E era de mim que eles cobravam acho que porque eu era mais falante, não cobravam as minhas irmãs, então eu que tinha que trabalhar mais, pois eu que era devedora para eles. Então eu saía mais cedo para cozinhar. Até cheguei a cobrir as minhas dívidas um pouco.

Depois de um ano, meu pai voltou para o Chaco de novo, e ele lá, alguém deixou alguma coisa ligada na cozinha, alguém estava cozinhando, não sei como uma viga de sustentação caiu, e caiu na casa, e como estavam cozinhando, a cozinha pegou fogo. Foi uma explosão! Ligaram-me de Puerto Villareal e eu já falei: “como está o meu pai?” e me falaram que ele estava assustado, que a casa tinha sido queimada. E eu fui de Ibigarsama até Villareal, ver o meu pai e buscá-lo. Ele estava sem roupa, sem nada, tudo tinha sido 
queimado.

Eu falei para ele não se dar por vencido, que íamos seguir trabalhando. Eu lembro que eu tinha B $\$ 70$, que era o capital para comprar a minha comida para vender, mas eu gastei tudo com o meu pai, comprei açúcar, arroz, azeite, a coca dele, pão e ele falava que ia se superar. Eu disse que ia embora, que meus filhos estavam sozinhos, mas no fim eu fiquei sem capital! Eu ficava imaginariamente conversando com minha mãe, pegava a sua foto e conversava com ela, perguntava: "Mami, o que vou fazer?".

E eu deixava as minhas filhas às vezes só com chá e pão, outras com Yupi e pão, suco. E não tinha mais gás para cozinhar. E justamente nesse dia meu pai chegou, estava com dengue! Chegou doente, com febre, trêmulo, não queria ir ao médico. Mas eu chamei o Dr. Jose Luiz assim mesmo, e contei para ele o que estava acontecendo. E ele disse que ia vê-lo, mas ele não foi! E coloquei o penico para ele urinar, ele chorava, chorava, chorava! E quando a temperatura abaixou, ele foi melhorando, se acalmando, dizendo que estava bem, mas eu sabia que ele não estava bem.

E assim amanhecemos, meu pai, meus filhos, e minha filha mais velha essa sim foi o meu marido (risos). Elas iam para a escola, às vezes ela queria me ajudar a vender, mas eu não deixava. Eu queria que elas estudassem. Mas nas escolas eles te pedem para comprar os materiais, depois as exposições, para as demonstrações de educação física, para música. E eu podia me esquecer de outras coisas, mas com as minhas filhas eu sempre estava presente. E com o meu pai também. E olha que ele também tinha problemas no coração, era doente do coração... e desde que minha mãe morreu ele não gostava mais de ficar em casa, dizia que tinha muitas recordações, claro, todos nós tínhamos. Até hoje, eu sinto tanta falta de minha mãe, agora mais do que nunca.

E nessa época eu sentia muita falta também, ainda mais depois de nos cortarem a luz e a água. Eu tinha que ir ao vizinho pedir água para cozinhar. E a vizinha um mês dava, no outro não. E eu seguia trabalhando, trabalhando. Consegui trazer de volta a água, a luz era de menos, e sempre era perigoso porque usávamos velas, e meu filho mais novo era muito travesso, derrubava a vela às vezes... 
E um dia saí de casa e vi a mãe da Rosa, a d. Rosa. Encontramo-nos e perguntei o que a Rosa estava fazendo da vida, e ela falou que a Rosa estava no Brasil, e quando eu ia me animar para ir. E eu respondi: “agora!". Era 09 de novembro de 2010. Ela perguntou: “de verdade?" e eu disse que sim, e ela falou que 4 outras pessoas iam, e então ela falou que ia comprar a minha passagem, para eu não me preocupar com isso. E eu falei que ia, que precisava ir, porque devia muito dinheiro para muita gente. E ela falou que era garantido ganhar dinheiro indo para o Brasil, trabalhando de costureira.

Era o que eu precisava para pagar as minhas dívidas. Então eu falei para ela comprar as passagens, que eu ia. Quando cheguei em casa vi minhas filhas pedindo coisas, para ajudar com os trabalhos manuais da escola, comprar materiais. E eu não tinha nenhum dinheiro, fui até a minha irmã pedir B \$10. E contei para as minha irmãs que ia para o Brasil e as duas me apoiaram e disseram que podiam cuidar dos meus filhos, para eu não me preocupar.

E o meu bebê tinha uns cinco meses quando a d. Rosa me chamou para viajar para o Brasil. E assim, eu peguei as minhas roupas, não, na verdade não tinha roupa, levei só roupinhas do bebê e peguei o ônibus, eu, D. Rosa, o pai e a mãe dela, que estava em Santa Cruz, onde ficamos por dois dias.

Esqueci de falar que quando minha mãe morreu, eu estava grávida. Ela não sabia, ninguém sabia. Estava escondendo essa gravidez, porque não sabia no que ia dar, porque, imagina, era o quarto filho que eu ia ter sem pai. Sabe, foi um descuido mesmo, porque foi um caso sem importância, eu não tinha namorado.

Combinei com minha irmã que ia mandar dinheiro para pagar as contas da casa. Eu falei para a Narly que ia trabalhar de costureira e ia mandar o dinheiro, e que ela podia ficar na casa da minha mãe, assim ela não teria que pagar aluguel. E a d. Rosa disse que se ganha bem no Brasil, ganhava uns US\$700 ou US\$800 por mês. E vendendo minhas comidas eu ganhava B $\$ 150$ por dia. Vendia de manhã de tarde e de noite. Ganhava em média B $\$ 3000$ por mês, mas variava e a promessa de ganhar dólares me fez viajar.

E quando estava em Santa Cruz já me dava pena e saudades das minhas crianças que ficaram. E a Rosa disse que eu poderia levar o meu filhinho de 5 meses. Mas em Santa Cruz 
descobri que para viajar precisava da Certidão de Nascimento e a autorização do pai para a viagem para passar pela fronteira. Me vi obrigada a mandar meu filho de volta para ficar com a tia dele. E como a filha da d. Rosa estava voltando para o povoado, eu pedi que ela o levasse, no mesmo dia em que íamos partir. Foi muito triste muito mesmo, porque ele ainda mamava, e não tinha organizado quem ia tomar conta dele, minha filha não podia, ela tinha escola, minha irmã já ia ficar com os meus outros filhos, mas pensei "seja o que Deus quiser".

Eu tinha decidido vir ao Brasil e pegamos o ônibus de Santa Cruz até Puerto Quijaro e de Quijaro até São Paulo. A d. Rosa foi com a gente. E tivemos que passar uma noite em Quijaro, a Rosa pagou tudo, já que eu não tinha levado nenhum dinheiro, mas ela me dizia que depois eu poderia pagar, que ia descontar do meu trabalho. Dizia: "Luze, se vai ganhar US\$700, US\$ 800, eu te desconto uns US\$ 100 , US\$50, pouco a pouco você me paga". Parecia fácil, então eu concordei, e logo viemos: a d. Rosa, sua mãe, avó e dois costureiros, D. Mery e Wilmer, todo mundo de Ibigarsama. Eu já tinha saído do meu povoado, mas não sabia o que podia me esperar. Eu vim ao Brasil antes, mas não tinha saído do aeroporto.

E chegamos na Barra Funda, a Rosa estava nos esperando. Pegamos o metrô e paramos na estação Brás. Do Brás fomos a pé até a casa dela. Era um sábado, 14 de novembro, ou 13 de novembro. Nos receberam bem, nos convidaram para um churrasco, e segunda-feira começamos a trabalhar.

A Rosa me mostrou qual ia ser a minha máquina, qual ia ser a da D. Mery. Eu sabia mexer na máquina, mas não tinha prática. Como falei, minha mãe me fez estudar costura, mas não praticávamos, então esse primeiro mês não costurei, trabalhei de cozinheira e me pagaram R\$ 300, foi o meu primeiro salário. Depois eu troquei com a D. Mery, ela foi cozinhar e eu costurar.

O meu cabelo era comprido, quase chegava até os meus pés. Chegamos em novembro, e como estava chegando o Natal, no dia 20 de dezembro eu vendi o meu cabelo. A Rosa e suas irmãs me davam medo, falavam que aqui no Brasil se eu andasse na rua iam cortar o meu cabelo, que eu tinha que tomar cuidado, que era melhor eu vender. Como a Rosa não pagou o meu salário, não pode ou não quis, não sei, então eu pedi para o Wilmer me levar onde vendia cabelo, porque eu precisava mandar dinheiro para a minha irmã. 
Saímos na chuva e vendi. Me pagaram $\mathrm{R} \$ 450$ e eu pensei: esse dinheiro deve ser o suficiente para voltar a luz na minha casa. E foi o primeiro dinheiro que eu mandei.

E chegou janeiro, eu comecei a costurar. Na verdade a Rosa queria que eu praticasse, mas eu peguei a prática bem rápido. Eu fiquei feliz quando terminou o mês e o meu primeiro pagamento como costureira foi de R\$700. "Que bom”, pensei. Fizemos a conta, ela descontou os vales, que eu usei para ligar para as minhas filhas, e esse dinheiro também mandei a Bolívia.

Aí passou o Natal, o Ano Novo, logo veio o Carnaval, seguíamos trabalhando. Depois veio março, e esses foram os únicos salários que eu recebi. Depois de abril, maio e junho não vi mais dinheiro. A Rosa me chamou para conversar e ela falou que como eu gostava de vender comida, deu a ideia que poderíamos abrir uma minipensão na parte de baixo da casa. Eu não achei má ideia, porque o marido dela tinha uns amigos que gostavam de beber, então ela pensou em vender cerveja e ela falou que os bêbados sempre gostam de comer e pediu para eu cozinhar a partir daquele final de semana. Então eu costurava de segunda a sábado até o meio-dia e no sábado eu cozinhava. Mas durante a semana eu trabalhava das $7 \mathrm{~h}$ até umas $2 \mathrm{~h}, 3 \mathrm{~h}$. Era muito trabalho. No final de semana eu saía para fazer as compras e trabalhava até umas $22 \mathrm{~h}$. E trabalhava domingo também, acordava às $7 \mathrm{~h}$.

E eu não ligava, tinha que trabalhar pelas minhas obrigações na Bolívia. E eu trabalhava assim. Aos finais de semana ela disse que ia me pagar US\$100, à parte da costura.

Quando não trabalhávamos ela ficava brava, ela mudava o seu humor muito. E ela nunca me pagou por cozinhar. Na verdade, depois de maio ela parou de pagar a costura também. Só dava “vales”, me dava R $\$ 50$, às vezes $\mathrm{R} \$ 20$. E eu não conseguia mandar esse dinheiro para a minha irmã. A filha da D. Mery que veio na época do carnaval, mas logo mudou de oficina, chegou a me emprestar $\mathrm{R} \$ 300$ para eu poder mandar para a Bolívia, porque todos os meus filhos fazem aniversário no mês de maio, precisava mandar dinheiro para o bolo deles. E eu não sabia o que fazer, implorei para a D. Mery para me emprestar, e ela pediu para a filha dela.

A filha da D. Mery saiu da Rosa depois que ela trouxe mais costureiros da Bolívia. $\mathrm{Na}$ verdade saíram todos, a única que fiquei fui eu, a que tinha mais para receber, e eu 
realmente pensava que ela ia me pagar esse dinheiro, fiquei tão alegre quando ela me falou que ia pagar US\$100 à parte, eu me esforçava pelos meus filhos. E ela tinha descontado a viagem já. E ela cobrou o justo, cobrou $\mathrm{R} \$ 300$, disse que era pela viagem e pelo cartão internacional, que na verdade eu nem precisava tirar.

E eu falava para ela que eu precisava desse dinheiro, eu devia muito na Bolívia. E ainda falei "minha mãe também devia, Rosa, e por sua culpa ela morreu, porque você nunca pagou o pasanaco". Ela dizia "não é por minha culpa, Luze, eu não tinha como mandar esse dinheiro". E eu: "mas você tem uma oficina agora, há dois anos, já dava para nos pagar. Eu preciso de dinheiro". Às vezes eu acreditava que ela queria pagar, às vezes não, mas o caso é que ela nunca me pagou.

Ela trabalhava com os seus familiares, seus primos e primas. Uma vez a sua prima ia viajar para a Bolívia e pediu a minha mala emprestada. Disse que me mandaria outra nova da Bolívia, e eu emprestei, é o meu jeito. Mas ela não devolveu. E eu fiquei pensando um jeito de sair de lá, mas não tinha mais mala.

E eu queria fugir de lá, e pedi a Rosa para sair, para mandar dinheiro para Bolívia. Ela me falou que eu devia terminar um corte e depois que terminasse eu poderia sair. Aí eu costurei rapidinho, tomei banho, saí e nunca mais voltei.

Fui para a oficina que a D. Mery estava trabalhando de cozinheira e sua outra filha de costureira, e o marido dela de ajudante. Não era muito longe da casa da Rosa. Passou uma semana, eu já estava trabalhando nessa outra oficina, voltei à casa da Rosa para pegar as minhas coisas. Eu saí de lá sem nada, nadinha, e quando voltei para pegar as minhas coisas e ela me ignorou, subiu para o andar de cima. O marido dela me pediu para voltar na segunda, porque eles estavam sem tempo. Disse por favor que queria só as minhas coisas de volta, que não tinha tempo de voltar na segunda. Aí a Rosa apareceu e disse que não ia deixar eu pegar as minhas coisas, que eu não podia entrar na casa disse "você saiu dessa casa, não pode mais entrar!”. E a irmã dela e a cunhada me deram uma bolsa com as minhas roupas, uma bolsa qualquer, ela não devolveu a minha mala.

E não estavam todas as minhas coisas lá. Faltava o meu cartão de entrada no Brasil, o tal do cartão internacional, o meu chinelo e as fotos dos meus filhos. Eu liguei para ela e disse que estava faltando coisas, e ela respondeu "não, eu coloquei tudo o que era seu nessa 
bolsa". Mas eu fiz as contas, e disse: "você me deve dinheiro. Você me falou que ia me pagar US\$100 pela comida, por eu ter cozinhado, e isso são uns US\$300, Rosa”. E ela disse que não me devia nada, e disse que era eu que estava devendo! Ela falou que o combinado era que se eu saísse da casa dela em menos de um ano, ela não me pagava! E no fim, ela não tinha me pagado e eu fiquei devendo $\mathrm{R} \$ 80$ ! E ainda falou, que eu poderia ficar onde eu quisesse.

Conversei com D. Mery, estava desesperada, só pensava nos meus filhos, e falei com o Dom Adam que sugeriu que deveríamos denunciá-la. Então fomos na Rua Coimbra e encontramos um jornal para Bolivianos, e falava de um lugar no Tatuapé para fazer a denúncia. Fomos lá, e nos mandaram para o CAMI (Centro de Apoio ao Migrante), e com eles fomos a Praça da Sé, ao Núcleo de Enfrentamento ao Tráfico de Pessoas. E de lá para a Delegacia. Não tudo no mesmo dia, claro. E até agora a polícia não fez nada. Eles prenderam a Rosa, mas sei que logo a soltaram. Eu tenho um pouco de medo dela querer se vingar, por isso não saio muito de casa.

Eu saí da oficina que estava a D. Mery e fui para outra oficina, que me tratam muito bem. Agora me dão comida de final de semana, na casa da Rosa não me davam. Na verdade ela dava dez ou vinte reais para a comida, mas eu usava esse dinheiro para ligar para a Bolívia. O meu amigo Wilmer, ou outro costureiro, é que comprava comida para mim, eu ficava super agradecida. Ele dizia que eu não precisava gastar o meu dinheiro, às vezes até ele mesmo comprava o cartão telefônico para mim, ele sabia que a Rosa não queria me dar vale, mas para ele ela dava!

Ele queria que eu ficasse tranquila, eu pensava muito no meu bebê, não me concentrava direito no meu trabalho. Eu chorava todos os dias à noite, de manhã e de tarde também. Às vezes nem comida eu queria, porque a comida da Rosa era café com pão, depois café com pão com mortadela, era sempre assim. Às vezes era frango, frango frito, frango frito e frango frito! De manhã, tarde e à noite. $\mathrm{O}$ mesmo sempre. E não dava para comer essa comida, então às vezes eu não comia, às vezes só comia porque tinha muita fome, às vezes o meu amigo Wilmer me encorajava a comer. Algumas vezes a gente cozinhava, mas ela regulava o arroz, regulava o azeite, regulava a batata. Então tínhamos que comprar, mas quem tinha que dar era ela! Um dia meu amigo ficou bravo e perguntou: "Rosa se você vai nos regular o arroz, regular a batata, regular o azeite, e então o que nós vamos comer?". E ela falava que estava sem dinheiro, que a firma ainda não tinha pagado. 
E o Wilmer era o que mais trabalhava, era o que mais ganhava, então ela respeitava ele um pouco. Mas ele falou que nem a ele ela estava pagando! Eu perguntei para ele o que faríamos, seguir sofrendo? E eu então cozinhava, e pedia para a Rosa anotar que estava comendo o prato de comida que eu mesma cozinhei. E ela anotava tudo!

\section{Quero ver minha família, e quero abrir um negócio aqui no Brasil}

Agora tudo o que eu ganho eu mando para a minha irmã. Nesse meu novo trabalho o dono já manda tudo direto. Meu sonho é trazer os meus filhos para o Brasil porque a vida na Bolívia está cada vez pior. Mas antes eu tenho que pagar toda a minha dívida, eu ainda não terminei de pagar tudo. Devo uns B\$7000 ainda. Para mim, sozinha e com filhos na escola, é difícil. E o prazo que me deram já acabou, já venceu.

O pessoal da Bolívia sabe da história da Rosa, mas não sei se sabem muito. Eu falei com minha irmã para explicar às pessoas que eu devia, mas eles não querem saber muito, claro, eles querem que eu pague. E eu sei que devo, e eu vou pagar! Quero pagar tudo este ano (2012).

E quando acabar a dívida quero trazer minha família, isto é, meus filhos. Aqui eles vão ter melhores condições. Minhas irmãs vão ficar com o meu pai, dá pena dele ficar sozinho. E meu pai depende de mim da mesma forma que meus filhos! Minhas irmãs o visitam de vez em quando.

Por enquanto não posso voltar pois os meus pensamentos ficam dizendo: "tenho que pagar o que devo, tenho que pagar o que devo". Mas eu quero ver minha família, e quero abrir um negócio aqui no Brasil. Fora que eu já me acostumei aqui. E eu gosto dessa oficina que estou trabalhando agora. A senhora é muito boa. Uma vez eu falei das minhas preocupações, que queria ganhar mais dinheiro, e ela falou para eu não me preocupar, que a gente ia ganhar mais dinheiro. Eles são bem conscientes. E te pagam no dia marcado, não esperam o final de semana para pagar.

Agora ganho entre $\mathrm{R} \$ 600$ a $\mathrm{R} \$ 700$, mais ou menos como um salário mínimo. Mas o que eu queria mesmo trabalhar é com comida, sair para vender. Estava falando para a D. Lucy, com quem eu trabalho agora, a gente podia vender na (rua) Coimbra, ou na (praça) 
Kantuta também. Mas é difícil encontrar espaço, acho que os bolivianos são egoístas, parece que não queremos que outra pessoa ganhe. Então sugeri para a D. Lucy para fazermos assim mesmo e vender perto da Coimbra e Kantuta. Mas como ela está grávida, não pode agora, então eu teria que começar sozinha, mas não conheço bem lá. Parece que é perto da Vila Guilherme, onde estou morando agora. E sugeri à ela para irmos lá para vermos como é.

Para os meus filhos virem ao Brasil, preciso que os pais deles autorizem a viagem, pois todos foram registrados com o nome do pai. E quando for de novo à Bolívia vou atrás de buscar essa autorização. Aqui minhas filhas vão poder ir à escola também, o menor ir à creche, e posso fazer o documento brasileiro deles. Minha irmã já tem uma carta-poder minha, ela pode tirar os meus antecedentes criminais da Bolívia para eu começar o trâmite para os meus documentos.

Sabe, eu não quero saber de homens, para casar. Eu gosto de viver sozinha, lutando, sendo independente. Minhas filhas já estão grandes, e eu não preciso de companheiro. Eu não me rendo, então não quero depender de um homem para que me diga que me ajudou. Não quero alguém que me dê mais contas na minha vida. Não quero ser igual às minhas irmãs, que são dependentes do marido. Talvez elas não se sintam capazes de ficarem sozinhas, eu não, eu não necessito, eu não preciso, eu trabalho pelos meus filhos, trabalho por mim, e o que eu devo estou pagando pouco a pouco, mas não preciso de homem. Minhas filhas talvez, é bom crescerem com uma figura paterna, mas se for viver mal, é melhor viver assim, sem pai.

Quando alguém vem me reclamar de homens eu digo que posso ajudar com tudo, menos com esse tema. Eu estou sozinha, estou bem, não tenho que lavar a roupa de ninguém, nem cozinhar, não quero ser escrava de homens.

\subsection{Nancy Pasis Perla}

\section{Eu tinha um dinheirinho}

Sou Nancy Pasis Perla, tenho 24 anos, sou boliviana. Meus pais são separados, meu pai mora na Argentina, e minha mãe mora em La Paz, na Bolívia. Eu não vejo o meu pai há 
sete anos, ele casou de novo e tem outros filhos. Minha mãe que me criou, mas ela casou de novo e também tem outros filhos. São três irmãos por parte da minha mãe.

Eu estudei até a secundária, ${ }^{92}$ em 2006. Minha mãe não tinha condições de me ajudar, de me dar dinheiro, então eu ajudava a minha tia, irmã da minha mãe. Aí eu tinha um dinheirinho e podia comprar os uniformes da escola, os materiais e outras coisas.

Ela me dava B\$50 para ajudá-la no seu mercadinho. Eu também limpava a casa dela, passava roupa, limpava os vidros. Para eu ajudá-la ela me ajudava também.

Eu morava em "El Alto" com minha mãe, estudava de segunda a sábado de manhã, e depois da escola eu descia até La Paz para ajudar a minha tia. Ela também comprava alguns mantimentos para a minha casa. Precisava ajudar minha mãe com um pouquinho de dinheiro, porque ela tinha três filhos e o salário dela não ajudava em nada, não abastecia a casa, e nós éramos em 4 filhos, ao todo 6 pessoas na casa.

Minha tia não me pagava muito bem, mas era minha tia, né? Às vezes ela me dava arroz, batata, essas coisas. Dizia: "vai, leva isso para a sua casa”. Ela me tratava bem, como uma filha. Seu filho era bem mais velho, tinha 35 anos, e ela mandou ele estudar no México e por lá ficou. E ela ganhava muito dinheiro, ela fazia de tudo. Morava com o outro irmão da minha mãe, moravam juntos, já eram velhinhos. Minha avó morreu quando eu tinha um ano e meio. Meu avô também morreu nesse mesmo ano que ela morreu. Minha mãe é a mais nova das filhas, hoje ela tem 48 anos, é super nova, quando eu nasci ela tinha 24 anos.

Depois que terminei a secundária, e minha tia voltou de uma temporada do México, ela me convidou para morar com ela em La Paz, porque ela se sentia muito sozinha. E minha mãe e meu padrasto brigavam demais. Brigavam por dinheiro, estas coisas. Eu não gostava de morar com eles. Aí fui morar com minha tia. Morei com ela por um ano, de 2007 a 2008.

Achei que vir para o Brasil era um jeito de ter dinheiro e de ser independente

Nisso, minha melhor amiga me perguntou se eu não queria viajar com ela. Ela disse

\footnotetext{
${ }^{92}$ Equivalente ao $1^{\mathrm{o}}$ ano do Ensino Médio.
} 
que ia viajar e queria que me levar, porque eu era a melhor amiga dela. E eu pensei que era em Santa Cruz ou no interior, mas minha amiga falou que era para o Brasil! Eu nem sabia onde era o Brasil, quer dizer, sabia onde que era, mas não sabia quanto demorava para ir para lá.

Aí eu topei, falei que ia com ela. Eu estava bem chateada com minha mãe e meu padrasto, eu tinha voltado a morar com eles e não estava dando mais. Cheguei a ficar dois meses lá, porque eu fui atropelada por um carro em La Paz, e minha mãe me tirou da minha tia para cuidar de mim.

Ela brigou com minha tia, disse que ela não cuidava bem de mim, que eu estava sofrendo, e ela me levou de volta. Aí em fevereiro de 2008 minha amiga me perguntou quando que eu podia ir, e como eu tava chateada com minha mãe, falei que podia ir a qualquer hora. Assim, em quatro dias fui para o Brasil.

Vim meio que na aventura, nada foi planejado. Pensei, "vou conhecer", não sabia como era, não sabia nada, só sabia que falavam outra língua, o português, que eu não sabia e nem entendia, mas eu falei "tá bom" eu gosto de me aventurar, de me arriscar, gosto de conhecer outras coisas, ter novas experiências, e sabia que na Bolívia não ia conseguir muita coisa.

E eu acabei vindo sozinha, minha amiga me enganou. O namorado dela não a deixou vir de última hora, eu vim com o irmão dela. E ela se casou com esse namorado. Eu só vim porque a passagem já estava comprada.

Eu levei na boa essa história da minha amiga não ter ido, porque aqui não estava dando com a minha mãe. Ela tem três filhos, todos bem novos, ela não conseguia cuidar de todos nós, às vezes não tinha almoço, a gente só jantava, e sempre ela dava o jantar com pão, para que desse mais a sensação que não estávamos mais com fome. As coisas lá são caras, não são como aqui no Brasil. As comidas são muito caras, e eu pensei comigo mesma: “aqui não está dando, eu vou embora". Vou trabalhar no Brasil e mando um dinheiro para a minha mãe.

Na verdade o convite da minha amiga era para vir para o Brasil, São Paulo, trabalhar com costura. Eu não sabia costurar, mas minha mãe tinha trabalhado no ramo da costura. E eu falei para a minha amiga que não sabia costurar, e ela disse para eu não me preocupar, 
pois se eu não aprendesse a costurar ainda podia trabalhar de cozinheira, ajudante. Ou ainda de "arrematadeira".

Eu não sabia quanto que poderia ganhar. Pagando 100, 300 contos, estava bom, não sabia quanto era o salário aqui. Falei para a minha amiga quanto ela achava que ia ser em dólares, e ela disse que achava que eu podia ganhar aqui até US\$150. Nossa, para mim isso era muito dinheiro!

Falei que ia vir sim, com esse dinheiro achava que ainda ia dar para mandar dinheiro para a minha mãe e para os meus irmãos. Meu irmão mais novo nessa época tinha 5 anos, e eu sabia que minha mãe precisava que eu a ajudasse. Todos esses motivos me fizeram vir para cá. Ainda mais porque a minha amiga já tinha um contato de trabalho aqui. Lá na Bolívia cada vez mais falam desse trabalho aqui, no ramo da costura.

Eu até tinha um namorado lá, mas eu acho que sou diferente, sou mais liberal, independente. Não queria que ninguém implicasse comigo, que me segurasse, que pegasse no meu pé. Sou assim desde nova, sempre gostei de trabalhar para ter o meu dinheiro, nem mesmo minha mãe tomava conta de mim. Por isso que era independente não gostava que ninguém falasse o que eu tinha o que fazer, não achei que o meu namorado poderia ser um empecilho.

Achei que vir para o Brasil era um jeito de ter dinheiro e de ser independente. Eu queria fazer faculdade mas sabia que minha mãe não ia poder me ajudar, então pensei: "não vou ficar aqui esperando, esperando, ficando com minha mãe. Assim eu não vou ter nada”. E vim para o Brasil para alcançar as metas que eu tracei para a minha vida.

E o irmão da minha amiga era a pessoa que conhecia quem precisava de trabalho aqui, o Sr. Juan Tadeo. Eles se conhecem da Bolívia, e ele pediu para o irmão da minha amiga me convidar. Ele pagou a minha passagem, mas eu não o conhecia.

E eu fui até Santa Cruz, mas ele não tinha mandado o dinheiro para eu vir do Paraguai até São Paulo. Eu avisei a ele que não tinha dinheiro e ele me mandou a passagem, e disse que ia descontando aos poucos do meu trabalho.

Eu achei de boa, ele mesmo falou que em dois ou três meses eu pagava tudo, e depois disso ele ia cancelar toda a dívida. Mas para atravessar o Paraguai ele só tinha me 
mandado a passagem, e eu não tinha nenhum dinheiro. Vim sem comer nada! Não comi e cheguei aqui com muita fome.

O ônibus chegou direto na Rua Coimbra, era um daqueles ônibus clandestinos, não era daqueles ônibus com papelzinho, que chega na Barra Funda. E é só descer do ônibus que tem um monte de bolivianos perguntando se você já tem trabalho. Quando você vem da Bolívia, ao descer do ônibus eles ficam perguntando: "Você tem trabalho? Quer trabalhar comigo?".

Mas no meu caso, eu já tinha o trabalho assegurado, e o Juan já estava me esperando quando cheguei. Para eles, mesmo se você nunca mexeu na máquina, é vantagem, porque eles te ensinam, de pouquinho. E compensa para eles, porque a pessoa que chega da Bolívia não sabe quanto é o salário, e todos os outros custos, mas as pessoas que estão aqui faz tempo já sabem, aí eles não querem esses. Querem os que chegaram da Bolívia, porque eles ficam um, dois anos com eles, pois até pegar a dívida e realmente aprender a costurar, o dono da oficina lucra muito em cima. Quem já está no Brasil e sabe costurar, num emprego assim que exploram muito, não ficam nem um mês, ou só fica até pagar a passagem e vai embora. E eles não querem pessoas que sabem costurar, senão é encrenca.

E eu cheguei num domingo, segunda já fui trabalhar, foi difícil no começo, mas eu me acostumei

E foi assim que foi comigo. Ele foi me buscar na Coimbra, deixamos as minhas coisas na casa dele, ele me deu comida. E minha primeira impressão foi boa, achei tudo legal. Claro, os patrões no começo são super simpáticos, te tratam bem, para tudo eles falam “oi tudo bem?".

Mas te enrolam tanto. Demorou para eu descobrir que eles estavam me enrolando, porque eles estavam sendo super legais comigo. E eu cheguei num domingo, segunda já fui trabalhar, foi difícil no começo, mas eu me acostumei.

No primeiro mês, o Juan Tadeo me pagou, claro, ele é esperto. No segundo ele me pagou com atraso, na verdade a mulher dele é que me pagava. E ela tinha medo dele, e em vez de pedir dinheiro para ele, ela pedia para mim! Ela um dia disse: "ai Nancy, me 
empresta esse dinheiro, o meu está no banco, o Juan saiu, depois eu te pago". Eu aceitei, porque eu não saía mesmo, não ia gastar aquele dinheiro naquele momento, eu só comprava cartão para ligar para a minha mãe na Bolívia. Então eu só pegava vales. Mas era tão difícil pedir esses vales! Eu percebi o jeitinho dele, um jeito muito mal-humorado. Até a com a esposa dele. Às vezes eu tremia de medo dele. E eu percebia que ela também tremia.

Aí, já no terceiro mês trabalhando ele não me pagou. Disse que depois me pagava, e no outro mês ele também não me pagou, ficou me enrolando, disse que ia guardar o dinheiro para mim, e por um lado eu até achei bom, porque tinha bastante gente lá e eu tinha medo de perder o dinheiro, que alguém me roubasse. Ele sempre me dava medo, falando como tinha ladrão no Brasil.

Combinei com ele que ele ia me dar todo o meu salário no final do ano, ele mesmo disse isso, que ia me dar o dinheiro no fim do ano. E ele me perguntou se no final do ano (2008) eu ia viajar para a Bolívia ou ia ficar com ele mais um ano. E eu sem pensar disse que ia ficar um ano mais.

E eu queria ficar um ano a mais, no começo fiquei meio ano chorando, sentia muitas saudades, não estava acostumada, não conhecia ninguém. Como eu chorava! E falava que no final do ano eu ia embora, eu não tinha amigos, eram só os trabalhadores, que eram quatro costureiros, e duas costureiras. Eu não conhecia nada, não conhecia a (praça) Kantuta, eu só saía com eles, que me levavam de carro.

No início eu não me virava sozinha, demorei um ano para começar a sair. Depois que fui à Coimbra, comecei a ir lá direto, porque de lá não tinha perigo de eu me perder, as ruas são quase todas iguais! Aí eu ia lá, dava uma olhada, comia, mas eu não conhecia ninguém, e como sou desconfiada, eu não converso com estranhos. Posso até falar um pouco, mas se não conheço, não falo. Mas depois aos poucos fui conhecendo pessoas, fazendo amigos. Muitos me convidavam para trabalhar com eles, mas eu tinha medo de sair da casa em que eu estava.

Eu me sentia segura com eles, sabe? Em um primeiro momento eu não queria sair de lá. Mas depois ele me enrolou mesmo. Falou de novo que era perigoso ficar com o dinheiro em casa no Brasil e me sugeriu de guardar, já que eu não ia viajar.

Eu nunca conseguia mandar dinheiro para a minha mãe. Quando eu pedia para ele, 
sempre pedia para eu esperar mais uma semana... Mas aí no final de 2009 eu pedi o meu dinheiro. E eles deram a desculpa que os cheques estavam parados, para eu esperar mais um mês que eles iam me dar tudo, que no fim de janeiro de 2010 ele ia me dar todo o meu dinheiro, que ia liquidar a dívida, e que se eu quisesse podia voltar para a Bolívia, ou continuar trabalhando com eles. Ele falou para eu esperar que ele ia me pagar direitinho.

E eu esperei esse mês, e fui falar com a mulher dele, a Ruth, ela me explicou que não tava saindo dinheiro, que era para eu esperar mais um pouco. Esperei até o final de fevereiro, e nada. Continuei trabalhando para eles, porque tinha medo que se eu saísse de lá eles iam mudar de casa, ou eles não iam me pagar facilmente, porque eu vi que eles também deviam para outras pessoas. Várias pessoas tocavam a campainha da casa e cobravam dinheiro. E eles mandavam o filho dizer que não estavam em casa, e eles estavam! E eu pensei, se eu sair daqui vai ser a mesma coisa, por isso que não saí de lá.

As pessoas ligavam também para cobrar e sempre inventavam uma desculpa. E a gente que atendia o telefone, e me desculpava, dizia que só era trabalhadora, e me mandavam o recado. Uma vez uma pessoa disse que ia chamar a polícia, eu fiquei super assustada. Ele devia pra tanta, tanta gente! Aí decidi ficar lá e esperar eles me pagarem, porque sabia que ele ia ficar brincando comigo, como brinca com os outros. Aí no final de 2010 eu perguntei de novo quando eles iam me pagar, ia completar 3 anos! E de novo me falaram que em janeiro iam dar.

\section{Tudo tem limite}

Aí eu decidi parar de trabalhar. Ele insistiu para eu continuar, mas eu disse que ia continuar morando lá, eles me davam a comida, pelo menos. Acho que eles tinham medo que eu pudesse fazer qualquer coisa. Ficavam espertinhos e eu continuei pegando vales. Fiquei quatro meses lá esperando, e o "cara" não me dava nada. Eu estava perdendo o meu tempo. No fim de abril uma amiga me encontrou e perguntou se eu não queria trabalhar com ela. Era uma senhora boa, ela disse, tem moradia e tudo, disse que eu não ia me preocupar. Pedi para ela ir comigo, disse que pagava a passagem, pois era no Tucuruvi, que eu não conhecia. E eu aceitei trabalhar lá. 
Essa foi uma amiga boliviana que eu conheci aqui no Brasil. Ela é casada. E via a minha situação, sabia que o Juan Tadeo não estava pagando, e ela insistiu para eu deixá-lo. E eu fui e trabalhei uma semana com essa senhora, e disse para ela que ia na casa dele buscar as minhas coisas. Minha amiga tinha me emprestado roupas, tudo, porque eu saí da casa dele sem pegar nada. A dona da oficina também me deu roupa, ela vendia na verdade, tem um box na feira da Lapa. Ela que me falou que eu não ia aguentar ficar com a mesma roupa todo o dia. Eu aceitei, ela era uma boa pessoa.

Mas eu fui com essa minha amiga, Patrícia, buscar as minhas coisas, caso ele não deixasse eu pegar as minhas coisas, ela estaria comigo para me ajudar. E ela ficou do lado de fora me esperando e eu demorei uma hora para pegar todas as minhas coisas. Eu encontrei o Juan Tadeo, ele é músico também, tem uma banda. Ele estava chegando quando eu estava saindo e eu disse que estava indo embora. Ele insistiu para eu ficar, me jurou que ia me pagar no próximo mês, disse que ia pagar de pouquinho, disse que eu era como uma filha para ele. Enfim, só "papo". Eu disse que ia deixar umas coisas, porque ele ainda ia me pagar, e deixei algumas roupas. E eu pedi uns $\mathrm{R} \$ 100$ para ele, e ele disse que não tinha, que entregou mercadoria e a pessoa não tinha pago para ele, disse que na segunda feira que ele ia pegar. E eu insisti, pedi dinheiro para a passagem e ele só tinha $\mathrm{R} \$ 10$ e me deu.

Dez reais por três anos de trabalho! E quando eles pediam eu ainda tomava conta dos filhos deles.

E eu dei muitas opções para ele, disse que podia me dar $\mathrm{R} \$ 1000$ em um mês, e depois no outro, falei que ele podia me dar uma máquina e etc., e ele me enrolou, enrolou, me fez de boba. Eu não briguei com ele, eu não gritei com ele, mas no dia que ele falou que ia me dar dinheiro ele não deu, eu gastei passagem... Tudo tem limite! Aí eu fiquei brava mesmo! Falei que era para ele parar de me ameaçar, que eu também podia ir à polícia, que ia denunciá-lo, ele pediu para por favor para não fazer nada!

Ele dança a morenada ${ }^{93}$ na festa da (Nossa Senhora de) Copacabana, lá na Barra Funda, e a roupa é caríssima, eles trazem da Bolívia, e custa uns R\$1500, R\$2000. Marido e mulher gastam quase $\mathrm{R} \$ 2500$. Que raiva eu fico só de pensar que eles me devem tanto e gastam tanto! É quase o que eles me devem por ano! Fora que nos finais de semana, eles

\footnotetext{
${ }^{93}$ A morenada é uma dança de origem do altiplano boliviano onde os dançarinos vestem máscaras, remetendo aos índios dançando como negros.
} 
gastam $\mathrm{R} \$ 300, \mathrm{R} \$ 400, \mathrm{R} \$ 500$. Para dançar e para beber eles têm, mas para me pagar não.

E como eu falei, eu cuidava dos filhos deles, e cozinhava para eles também. Eles não me pagavam extra, claro, e ainda achavam que me faziam um favor, pois eles me deixavam comer da comida deles, como se fosse um pagamento!

Mesmo eu morando no Tucuruvi queria resolver o meu problema. Eu não tinha tempo de ir na casa dele, às vezes ia lá aos finais de semana, às vezes ligava, e ele sempre respondia que ainda não tinha sido liberado dinheiro, essas desculpas. Eu não queria brigar com a mulher dele, porque ela é legal e também é oprimida, e o marido dela é prepotente e fica bravo rápido.

Em novembro de 2011 eu fui trabalhar com uma brasileira em (bairro) Itaquera, e contei para ela que o cara me devia. Tive que contar para ela, pois às vezes eu saía durante a semana para ir cobrar na casa dele, e tive que explicar toda a situação. Ela me aconselhou ir à delegacia. E eu fui, achei que ia ser rápido, e quando eles me atenderam o moço da delegacia disse que sabia que tinham muitos casos parecidos, mas que não era lá que eu devia fazer a denúncia, que eu devia ir ao Ministério do Trabalho, e me deu o endereço. Mas eu não fui imediatamente pra lá, porque ainda acreditava que ele podia me pagar, pois falou que em 15 dias ia me dar uma máquina como pagamento.

Mas claro, ele me enrolou de novo e não me deu o dinheiro. Ele não estava nem aí. Não queria saber se eu perdia dia de trabalho, se eu gastava com condução. E só me enrolava. Às vezes dizia que ia me dar o valor da passagem. Que desaforo. E eu tinha dores de cabeça, pensava nisso o dia todo. E quando disse para ele que ia tomar outras providências, ele começou a me xingar, e logo começou a pedir mais 2 meses para me pagar, disse que em meio ano me pagava tudo. Mas eu pedi para ele baixar o tom de voz dele, que eu não tinha ido com a polícia, e que eu tinha dado quase um ano para ele me pagar, que tinha dado várias opções para ele me pagar. Que pessoa egoísta! Eu dizia a ele: “você tem a sua família, sua casa, sua oficina, eu também quero ter essas coisas!”. E ele falou para eu me acalmar que ele estava sem dinheiro, mas que ia conseguir. E eu caí de novo na dele. Que tonta que eu sou. Que raiva! Porque no dia que ele falou que ia me pagar, fui à casa dele e ele estava bêbado!

Voltei segunda-feira, eles estavam saindo e ele disse que não tinha tempo para falar 
comigo! Conversei com a mulher dele, falei que eu tinha trabalhado, que eu queria meu dinheiro de volta. Falei que eu não tinha xingado, não tinha ameaçado, mas disse que tudo tinha limite. Disse que eu ia tomar providências e que aí não ia mais falar com eles, que ia ser outra pessoa. Mas ele me pediu para conversar mais um pouco, ele estava saindo e pediu para entrar no carro dele, mas o sogro dele estava lá, e o sogro dele é calmo e não sabe dessas dívidas, então ele ficou disfarçando e pediu para a mulher dele levar o sogro para dar uma volta.

E ele continuou dizendo que não tinha como me pagar naquela hora, que não sabia de onde ia tirar, me mostrou a carteira dele, que pessoa "idiota", eu falei que já estava cansada dessa enrolação, eu não consigo entender como uma pessoa pode fazer isso. Eu fui muito paciente e disposta a entender. Mas como uma pessoa que não tem dinheiro pode em um dia na sua casa fazer uma festa e ficar bêbada? Nisso ele gasta $\mathrm{R} \$ 100$ que não é nada para ele, mas é bastante para mim.

Eu falei para ele: "eu tenho meu par, eu quero viver com ele, casar, ter minhas coisas, minha oficina, eu quero! Eu não estou te pedindo dinheiro de graça, estou te pedindo algo que me pertence". E ele queria saber se eu era casada no cartório, queria saber quem era o meu namorado, queria ver a certidão de casamento. E ele até então nem ligava para mim, e depois queria saber tudo isso. Poxa, eu só quero o meu dinheiro!

Cansei! Dei 15 dias para ele, disse para ele se entender com outra pessoa, disse que não queria falar sobre isso, já tinha falado muito, falado de boa. Disse que estava farta com ele.

\section{Na vida precisamos ter alguns tropeços}

E procurei o Ministério do Trabalho. Mas lá não foi animador, eles não disseram como iam resolver o meu problema. Contei tudo para o auditor fiscal, contei do meu salário, que eu tinha trabalhado 3 anos, falei do total de dinheiro que ele me devia, falei que eu tinha dado chances para ele me pagar, que falei que podia me pagar em máquinas, em parcelas, enfim. No fim só me deram a indicação do CAMI (Centro de Apoio ao Migrante) e disseram que lá poderiam me ajudar. Eu fiquei aliviada, tirei um peso das minhas costas. Foi o 
primeiro passo, mas não pude ir diretamente ao CAMI.

Mas nessa época eu comecei a trabalhar em Americana, bem longe. Eu não sabia onde era, não sabia que era outra cidade. Mas o salário era muito bom, apesar da passagem de ida e volta ser quase sessenta contos.

Eu aprendi a falar bem o português porque na casa do Juan Tadeo a gente ouvia muito rádio. Ouvia principalmente música sertaneja, que é mais devagar. E também descobri que tinha um tio e umas primas aqui. Todas falavam português, e também fui aprendendo com elas. Esse meu tio é irmão do meu pai, e eu não o via há 19 anos. Ele me viu pequeninha e depois mudou da Bolívia para o Brasil.

O Juan Tadeo não quis dar o contato do meu tio. Disse que não tinha, mentiu dizendo que não tinha o telefone dele. Mas uma vez fui numa festa de um amigo dele, e estava sentada, vi uma agenda telefônica, e tinha os contatos do meu tio, Ricardo Apazi! Nossa! Eu não tinha caneta, mas memorizei. E ele mora perto da (praça) Kantuta, onde tem dois prédios amarelos grandes!

Foi bom saber que eu tinha um parente por perto. Minhas primas me ajudaram a aprender melhor o português, já que vieram para o Brasil com três, um ano de idade. E por terem vindo tão novas, elas que não falam espanhol!

E como tenho tanta vontade de continuar aqui no Brasil, isso aumentou mais a minha vontade de aprender o português. Mas eu quero voltar para a Bolívia, só para passear, no final do ano. Porque eu já acostumei aqui. E quero ser modelista, que é aquele que sabe desenhar todas essas as coisas.

E meu namorado, que também é boliviano, me incentiva muito a estudar. Ele fala para eu fazer faculdade de moda, me ajudou a tirar os meus documentos. E ainda foi comigo para Americana. Ele está aqui há 8 anos, e eu gosto muito dele.

Sabe, eu acho que na vida precisamos ter alguns tropeços. Senão não faz sentido, senão a gente não aprende, pensa que tudo é fácil, legal, está no colo da mãe, não tem nenhuma preocupação. Mas quando saímos do colo de nossa mãe, aí que temos que nos virar, temos que aprender a se virar na vida. E foi por isso que eu quis vir para o Brasil, se eu ficasse na Bolívia eu não ia aprender as coisas, experimentar. 
Lá na Bolívia não são todos que querem sair de casa. Os filhos ajudam a mãe, ajudam o pai, trabalham às vezes desde os sete anos, vendendo chiclete, às vezes com cinco anos já estão vendendo chicletes nos ônibus. A vida é muito dura lá. Então a luta para sobreviver é familiar, todos ajudam, mas todos os filhos ficam nessa dependência dos pais.

Acho que é por isso que a maioria dos bolivianos agora quer vir ao Brasil, para ter uma vida melhor, ter suas metas, acho que pensam no futuro, principalmente mulheres jovens. E nós pensamos num futuro melhor para as nossas famílias, nossos pais, tudo isso. Não sou só eu que penso que vir para o Brasil é uma oportunidade de ajudar meu pai e minha mãe. Muitas querem ajudar, e aqui tem oportunidades que na Bolívia não tem. Aqui tem bolsa família, lá não tem essas coisas...

Aquela minha amiga que me convidou para vir para cá, no final ela veio, morou no Bom Retiro. Anunciou meu nome na rádio, mas eu não escutei, me falaram depois, nos desencontramos. Mas ela ficou aqui para ter a filha dela, do mesmo namorado que não deixou ela vir da outra vez.

O que eu quero fazer agora é trazer a minha mãe para passear aqui. Mostrar como eu evolui, mesmo depois de tudo o que sofri. 


\section{ELAS QUE MIGRAM}

Neste capítulo, a partir das histórias de vida, pretendemos destacar alguns aspectos da migração dessas mulheres sul-americanas, como a conquista de espaços, a mobilidade, a vida transnacional, a relativa liberdade na escolha da profissão e as atividades que exploram a vulnerabilidade, como o trabalho escravo e o tráfico de pessoas.

E a análise dessas narrativas deve ser compreendida a partir da perspectiva das relações sociais de sexo, e pela influência do momento histórico pelo qual passou o movimento de mulheres: a percepção de que uma grande quantidade de trabalho era realizada de forma gratuita pelas mulheres, invisibilizado e justificado por sua natureza de cuidadora, maternal.

Feministas trouxeram à tona que o trabalho no espaço privado, familiar, também é trabalho. E no âmbito do trabalho produtivo, esse é um espaço em que se estabelecem relações de poder entre homens e mulheres. De um lado, a produção econômica, de outro, a reprodução social, sustentada por mulheres que garantiam o bem-estar da classe trabalhadora. Apesar de servir como base para a organização social, a separação entre as responsabilidades familiares e trabalho assalariado não significou a permanência das mulheres dentro do lar. Mas implicou a vinculação da força de trabalho feminina a uma mão de obra barata e específica para determinados tipos de trabalho.

As historiadoras Joan $\operatorname{Scott}^{94}$ (1994) e Michelle Perrot ${ }^{95}$ (2005), ao abordarem a situação das mulheres trabalhadoras, demonstram que a transferência da mão de obra feminina do trabalho em domicílio para o trabalho assalariado ocorreu em setores específicos, como na indústria de confecção e no setor de serviços, porém ainda como uma extensão dos serviços do lar. Realizado seja onde for, o trabalho assalariado das mulheres tem como característica em comum salários inferiores aos dos homens.

O aumento da participação de mulheres nas migrações internacionais pontua que esse não é um fenômeno neutro em relação ao sexo, como também vimos nas entrevistas. E

${ }^{94}$ SCOTT, Joan Wallach. A mulher trabalhadora. In: DUBY, Georges; PERROT, Michelle (Dirs.). A histó ria das mulheres: o século XIX (vol.4). Porto: Edições Afrontamento e São Paulo: Ebradil, 1994. p. 443- 475.

${ }^{95}$ PERROT, Michelle. As mulheres ou os silêncios da história. Bauru: EDUSC, 2005. 
a interação entre homens e mulheres não é produto de sua condição biológica, mas de uma relação construída socialmente.

Scott (1995) discute essa relação entre os sexos, em seu texto chamado "Gênero uma categoria útil de análise histórica", ${ }^{96}$, e traz uma posição desafiadora para a sexualização do estudo historiográfico.

O termo "gênero" emergiu das feministas estadunidenses que queriam sublinhar o caráter social das distinções baseadas no sexo, rejeitando o determinismo biológico implícito no uso de termos como "diferença sexual". De outro lado, o gênero destaca o aspecto relacional, em que mulheres e homens são definidos em termos recíprocos e nenhuma compreensão de qualquer um pode existir sem ser através de um estudo separado.

Este modelo proposto, e o interesse pelo trabalho com categorias como classe, raça e gênero, propiciou a análise das narrativas que envolvem oprimidos e a razão de sua opressão. E na década de 1970, com a entrada das mulheres nos círculos universitários, "foise produzindo certa feminização do espaço acadêmico e das formas da produção dos saberes". 97

As mulheres na universidade começaram a reivindicar o seu espaço na história, e com isso veio à tona seus temas, inquietações e problematizações. Mais do que acrescentar novos temas, a análise da relação da experiência masculina e feminina no passado e sua conexão com a história passada e a presente deram ensejo a este desafio de incluir as mulheres no discurso histórico, e ainda encontrar as categorias adequadas para conhecer os mundos femininos e transpor interpretações, principalmente aquelas vistas pela ótica exclusivamente masculina.

Muito embora haja uma preocupação em questionar a dominação masculina nos discursos e interpretações, a discussão sobre gênero vem de encontro também à reivindicação da construção de uma nova linguagem que revele o olhar específico da experiência cultural e historicamente constituída.

${ }^{96}$ SCOTT, Joan Wallach. Gênero: uma categoria útil de análise histórica. In: Educação \& Realidade. Porto Alegre, vol. 20, nº 2,jul./dez., 1995.

${ }^{97}$ RAGO, Margareth. Descobrindo historicamente o gênero. In: Cadernos Pagu. Campinas: Unicamp/NEG, n. 11, 1998. p.91. 
Para além da inclusão das mulheres na historiografia, foi necessário pensar em formas de conhecer o mundo da mulher e falar de suas práticas no passado, no presente e propor interpretações que não eram imaginadas pela ótica masculina. ${ }^{98}$

E o estudo de gênero pode trazer a dimensão analítica das diferenças sexuais, sexualizando as experiências humanas, não simplesmente por determinações biológicas, mas por experiências históricas marcadas por valores, pensamentos, cultura e práticas sociais e individuais, que também se diferenciam sexualmente.

$\mathrm{Scott}^{99}$ divide as abordagens do tema gênero utilizadas por historiadores em duas categorias: uma descritiva, despreocupada em atribuir uma causalidade, mas apontando a existência do fenômeno; e a outra causal, teorizando sobre a natureza dos fenômenos e das realidades.

De um lado, tem-se a utilização do termo como sinônimo de "mulheres", com o propósito, a partir da erudição do termo, de dar um caráter científico, dissociando-o da política do feminismo. Quando referido neste sentido, não implica numa tomada de posição sobre relações desiguais de poder, e sim constitui um aspecto daquilo que se poderia chamar de busca de legitimidade acadêmica para os estudos feministas nos anos 80 .

Por outro aspecto, o termo "gênero" pode ser utilizado para apontar que qualquer informação sobre mulheres é informação sobre homens, e que um implica estudar o outro, ou seja, que o mundo das mulheres faz parte do mundo dos homens e vice-versa. Estudar as mulheres de forma separada continuaria com a ideia que homens e mulheres vivem em esferas separadas.

Nesta linha, o gênero se propõe a incluir as relações sociais entre os sexos, independente das explicações biológicas ou de outras criações que remetam aos papéis supostamente designados para cada um. Enfatiza um sistema que inclui o sexo, mas não é determinante por ele, e nem determina a sexualidade.

Entendemos que o termo faz parte da tentativa que o movimento feminista

\footnotetext{
${ }^{98}$ RAGO, 1998, op. cit., p. 95.

${ }^{99}$ Ibidem, p.74 -75.
} 
desprendeu para reivindicar um espaço e apontar a falta de teorias para explicar diferenças e desigualdades entre homens e mulheres. Como apontamos acima, a preocupação teórica com o gênero veio à tona no final do século $\mathrm{XX}$, o que significa que estava ausente das teorias sociais formuladas até esse período, e ainda a dificuldade que as feministas tiveram para incorporar o termo "gênero" às abordagens teóricas existentes que descolam da representação binária homem versus mulher.

Para suprir esta lacuna, concordamos com Scott, que gênero é um elemento constitutivo de relações sociais percebidas nas diferenças entre os sexos, e é uma forma de dar significados às relações de poder. Portanto, não se trata de reparar uma exclusão, e sim de buscar formas de dar legitimidade a este campo de estudos, que envolve as mulheres na História e nas suas relações de gênero.

Conforme as historiadoras Perrot e Scott, o surgimento de uma sociedade industrial e urbana afetou diferentemente os sexos. Nesse sentido, a suposta neutralidade da ciência e da política invisibilizou o papel das mulheres na manutenção do sistema capitalista e sua contribuição ao sustento e bem-estar de inúmeras famílias.

A mobilidade transfronteiriça atrai a atenção da política internacional e as questões que envolvem a migração são recomendações para a agenda política global. Conforme Nicola Piper, a partir da última década do século XX, os estudos sobre migração centrados na mulher se deslocaram para uma análise de gênero. ${ }^{100}$ Nesta mudança de foco percebe-se que os pesquisadores deram visibilidade ao debate da migração feminina, o que possibilitou reconhecê-la como um fenômeno de gênero.

Para Laura Oso Casas, ${ }^{101}$ o tema passou de marginal, com pouca produção científica, para um crescente objeto de estudo. Segundo ela, durante as décadas de 1970 e 1980 as pesquisas se centraram em denunciar a invisibilidade das mulheres migrantes. Atualmente, segundo a autora, predominam pesquisas sobre a feminização das migrações. A partir dessa

\footnotetext{
${ }^{100}$ PIPER, Nicola. Gender and Migration. Paper preparado para o Policy and Research Programme of the Global Commission on International Migration. 2005. Disponível em: <www.gcim.org>.

${ }^{101}$ OSO, Laura. Migración, género y hogares transnacionales. In: CONGRESO DE LA INMIGRACIÓN EN ESPAÑA, 5, Valencia, 2007.
} 
premissa atual, ela e Jean Pierre Garson" ${ }^{102}$ perguntam: “¿realmente estamos ante una feminización de la migración o más bien ante una feminización del discurso migratorio?".

Dados quantitativos, de acordo com Hania Zlotnik, ${ }^{103}$ indicam que as mulheres sempre tiveram participação ativa nas migrações. Em 1960, entre 100 migrantes, 47 eram mulheres. Desde então o número de mulheres migrantes internacionais tem aumentado: $48 \%$ em 1990 e quase 49\% (48,8\%) em 2000. Embora o aumento de mulheres seja crescente, ele é pequeno comparado com o quadro que se tinha em 1960.

A demógrafa Silvia Giorguli Saucedo ${ }^{104}$ considera que cada fluxo migratório tem suas variações no tempo, e que em alguns países a migração é composta por um fluxo maior de mulheres. Mas que desde a década de 1980 não houve uma mudança significativa no número das mulheres que migram.

Arriscando a resposta à pergunta de Casas e Garçon, entendemos que o crescente interesse científico nos assuntos de gênero e migração ganhou maior visibilidade, acentuando o discurso da feminização da migração. A ênfase na produção científica para enfocar as mulheres migrantes e reivindicar o seu papel econômico e social é que ganhou força. E, assim, a característica da feminização das migrações se dá de forma qualitativa, com a referida visibilidade ao fenômeno das mulheres no processo migratório.

Entretanto, vale citar um estudo de 2010 sobre Mulheres Migrantes Andinas. ${ }^{105}$ Ao tratar sobre migrantes de países andinos para países europeus, a pesquisa demonstra que a mulher migrante se apresenta quantitativamente como maioria dos migrantes andinos para o país espanhol.

[...] los registros indican que la cifra de inmigración boliviana es en un $56 \%$ femenina; en cuanto a Colombia, alcanzaba al 55\% del total; en el

\footnotetext{
102 OSO Casas, L.; GARSON, J-P. The feminisation of international migration: Migrant Women and the Labour Market: Diversity and Challenges. In: OECD AND EUROPEAN COMMISSION SEMINAR, Bruxelas, 2005.

${ }^{103}$ Zlotnik, 2003, op. cit. Disponível em: <www.migrationinformation.org $>$.

${ }^{104}$ Disponível em: <www.cmanoticias.com.mx/node/63681>.

${ }^{105}$ ARTEAGA, Ana María. Mujeres en la migración andina hacia países de la Union Europea y especialmente a España: Contexto, Políticas y Gestión Migratoria. Disponível em: $<$ http://www.oxfamintermon.org/sites/default/files/documentos/files/101103_mujeres ndinas.pdf $>$.
} 
caso ecuatoriano representaba $51 \%$ y de Perú el $52 \%$ eran mujeres. ${ }^{106}$

Segundo o mesmo estudo, a razão pela qual as mulheres são atraídas a migrarem para a Espanha são as diferenças salariais e as oportunidades de trabalho em nichos específicos do mercado espanhol: o trabalho doméstico e os serviços de cuidado.

Especificamente na América Latina, de 1960 a 1990, enquanto o número de homens economicamente ativos aumentou de 80 para 146 milhões, o número de mulheres mais que triplicou, saltando de 18 para 57 milhões. No mesmo período, enquanto a taxa de participação feminina na População Economicamente Ativa (PEA) aumentou de 18,1\% para $27,2 \%$, a taxa masculina diminuiu de $77,5 \%$ para $70,3 \%{ }^{107}$

Nas histórias de vida aqui presentes, as oportunidades de um modo geral fizeram a diferença, e não apenas a chance de ter um emprego. Dora, que teve a sua migração motivada pelo tratamento de saúde do filho e posteriormente da filha, viu a estada em São Paulo como condição para criar também o seu filho do meio. Cecília, que em um primeiro momento saiu de seu país para se reunir com o marido, viu sua mudança para um terceiro país como oportunidade de libertação de um passado de violações e sofrimento.

Cristina e Nancy não tiveram a iniciativa de mudar de país, mas aproveitaram o convite de amigas e tomaram a decisão em alguns dias. A paraguaia analisou o convite junto com a sua mãe, e a boliviana foi atrás de uma aventura. Ambas, assim com Luzetânia, vieram trabalhar para a engrenagem que move a indústria da confecção, como muitas que vêm ao Brasil.

As políticas de migração para trabalho nos países de destino, ainda que pareçam neutras em relação ao gênero, são embasadas em um modelo focado para trabalhos masculinos. A diretora geral da Organização Internacional das Migrações, Laura Thompson, defende que:

[...] é preciso uma política de migração mais sensível às especificidades de

\footnotetext{
${ }^{106}$ Ibidem, p. 7.

${ }^{107}$ ABRAMO, Laís. A situação da mulher latino-americana - o mercado de trabalho no contexto de reestruturação. In: DELGADO, Didice G., CAPPELLIN, Paola e SOARES, Vera (Orgs.). Mulher e trabalho experiências de ação afirmativa. Boitempo Editorial, São Paulo, 2000. p.76-93.
} 
gênero, sabendo que homens e mulheres têm diferentes necessidades e oportunidades, antes, durante e depois da migração. Mais oportunidades para migrar de forma regular, ajudariam a prevenir com que a mulher se envolva em situações de exploração e abuso. ${ }^{108}$

A precarização do trabalho da mulher, segundo Helena Hirata, é mais evidente do que a do trabalho do homem. Ela aponta que mesmo com todas as análises sobre as sucessivas crises mundiais, muito poucas se voltam para compreender os impactos refletidos sobre os homens e as mulheres. As mulheres são majoritárias nas situações de desemprego, particularmente de desemprego oculto pelo desalento. ${ }^{109} \mathrm{E}$ esta precarização afeta não só à mulher, mas a sua família, que tem que passar por reestruturações que impactam todo o seu núcleo familiar. ${ }^{110}$

Essa sobrevivência, a qual Hirata chama de "precária", acaba se relacionando com a possibilidade de migrar e envolve vários aspectos, configurando um processo de vulnerabilidade em cascata: não acesso (e/ou precário) ao trabalho e à renda; pouca escolaridade; falta de acesso a outros direitos sociais básicos (moradia, saúde), que se associam a fatores mais subjetivos e pessoais: vida familiar conturbada, fragilidade nos vínculos afetivos, exposição à violência. Uma diversidade de fatores que passam, assim, a configurar risco ao bem-estar das mulheres e influenciam decisivamente na opção por migrar, sem, muitas das vezes, dimensionar os riscos que esta opção pode envolver.

Luzetânia vive essa situação desde os seus primeiros meses em São Paulo. A falta de recursos financeiros dela e de sua família a fez ficar sem os seus quatro filhos e migrar. E para poder honrar com o acordo em ajudar a sua família, e na impossibilidade de enviar dinheiro, se desfez dos seus longos cabelos cultivados por anos, que fazem parte da

\footnotetext{
${ }^{108}$ Tradução livre do inglês. International Organization for Migration, IOM. Gender and Migration News, edição 34, abril de 2010. Disponível em:

$<$ http://www.iom.int/jahia/webdav/site/myjahiasite/shared/shared/mainsite/published_docs/periodicals_and_ne wsletters/gender_bulletin_apr10.pdf>.

${ }^{109} \mathrm{O}$ desemprego por desalento é uma categoria estatística utilizada pela Fundação Seade e pelo Departamento Intersindical de Estatística e Estudos Socioeconômicos (Dieese) desde 1984. É empregado para se referir aos indivíduos que não possuem trabalho e nem procuraram nos últimos 30 dias, por desestímulos do mercado de trabalho ou por circunstâncias fortuitas, mas apresentaram procura efetiva de trabalho nos últimos 12 meses.

${ }^{110}$ HIRATA, Helena. Emprego, responsabilidades familiares e obstáculos socioculturais à igualdade de gênero na Economia. In: CONFERÊNCIA REGIONAL SOBRE A MULHER DA AMÉRICA LATINA E DO CARIBE, 11, Painel. Brasília, 14 jul. 2010.
} 
identidade daquelas oriundas das regiões altiplânicas. ${ }^{111}$

A pobreza da mulher faz com que ela opte por escolhas difíceis que envolvem não só ela, mas também seus dependentes, e que podem acarretar a separação, o afastamento de seu núcleo familiar, de sua cultura, e que pode submetê-la a qualquer emprego, também passível de violência, mesmo que simbólica.

A análise aqui trazida é muito breve para abranger todos os aspectos que constituem o entendimento das relações de gênero e que envolvem um processo de migração feminina. Porém, o diálogo entre campos de saber possibilita novos olhares e contribui na formulação de um pensamento científico que não tenha ambições de neutralidade ao refletir sobre a complexidade da vida cotidiana. As mulheres aqui retratadas com suas histórias de vida apontam para a possibilidade de construção de novos olhares na formulação de um pensamento.

\subsection{Elas que vivem a vida transnacional}

O resultado da experiência migratória sujeita todas as pessoas que migram a mudanças nas estruturas sociais, nas identidades, nas atitudes e nas práticas, independente do motivo que levou à mobilidade e do país que migrou.

O transnacionalismo é um fenômeno comum a quem se desloca e que apresenta oportunidades e desafios. É definido pela Organização Internacional das Migrações como “o processo pelo qual os indivíduos estabelecem e mantêm ligações socioculturais para além de fronteiras geopolíticas", ${ }^{112}$ ou seja, é o processo centrado em práticas além das divisas geográficas, transcendendo o espaço nacional como o principal ponto de referência.

Em se tratando de migração, estar ligado a vários lugares ao mesmo tempo é uma característica definidora da experiência de ser migrante. As trocas e interações através das fronteiras são uma parte regular das realidades e atividades dos migrantes, como a própria família.

\footnotetext{
${ }^{111}$ VIDAL, Dominique. Convivência, alteridade e identificações. Brasileiros e Bolivianos nos bairros centrais de São Paulo. In: BAENINGER, Rosana (Org.). Imigração Boliviana no Brasil. Campinas: Núcleo de Estudos de Populações/ Unicamp, 2012. p. 98.

${ }^{112}$ Tradução livre do International Migration Law N ${ }^{\circ} 25$ - Glossary on Migration, p. 100. Disponível em: $<$ http://publications.iom.int/bookstore/free/Glossary\%202nd\%20ed\%20web.pdf >. Acesso em: 29 dez. 2013.
} 
A família transnacional é aquela cujos membros "vivem algum ou a maioria do tempo separados entre si, mas que mantêm a coesão e criam algo que pode ser visto como uma noção de bem-estar coletivo e de unidade, nomeadamente, 'estrutura familiar' mesmo para além das fronteiras nacionais."113 São concebidas a partir de suas dinâmicas de negociação e reconfiguração constante, conforme sua capacidade de adaptação através do lugar e do tempo.

As mulheres que têm suas histórias de vida retratadas neste estudo mantêm esses laços familiares com seu país de origem e vivem a transnacionalidade. Nancy se preocupa em mandar dinheiro para sua mãe e seu irmão mais novo, que estão na Bolívia. Cristina não só dá satisfações à mãe, mas também quer que ela a veja como um motivo de orgulho. Segura de suas escolhas e com uma mínima estabilidade, trouxe o seu irmão à São Paulo, seguindo o seu exemplo.

Luzetânia está sozinha no Brasil, enquanto suas irmãs dependem do dinheiro que ela manda para Bolívia para criar seus quatro filhos, e sonha com o dia em que poderá trazê-los para perto. Dora migrou para a sobrevivência de seus filhos e mantém um laço afetivo com a família, procurando sempre falar o guarani, e se considerando ainda casada, mesmo depois de dez anos sem convivência com o marido. E Cecília, que teve a experiência de criar seus filhos sozinha, primeiro na Argentina, sob o espectro de violência do primeiro marido, e depois realizada profissionalmente e como matriarca em São Paulo, onde também já estavam estabelecidos alguns de seus irmãos.

Para Bjeren, ${ }^{114}$ a família transnacional pode ser entendida como aquelas que têm as relações de parentesco coletivas com "nós residenciais" em pelo menos dois países. Estas unidades residenciais não são estáticas, e podem mudar ao longo do tempo em termos de composição através da imigração, emigração e retorno de membros da família. Além disso, as famílias podem mudar devido à constituição de família e à alteração de esquemas de trabalho. O elemento de transnacionalismo destas famílias desafia, por conseguinte, a noção de residência partilhada em famílias geograficamente separadas mas mantendo elos sociais,

\footnotetext{
${ }^{113}$ BRYCESON e VUORELA apud ACP OBSERVATORY ON MIGRATION. Disponível em: $<$ http://www.acpmigration-obs.org/sites/default/files/EN-BN06Families.pdf $>$. Acesso em 07 jan. 2014. ${ }^{114}$ BJEREN, G. Gender and reproduction. In: HAMMAR, T.; BROCHMANN, G.; TAMAS, K. e FAIST, T. (Orgs.). International migration, immobility and development: multidisciplinary perspectives. Oxford, 1997. p. 219-246.
} 
culturais, reprodutivos e de rendimento entre fronteiras. ${ }^{115}$

Os processos e as relações entre as pessoas definidas como parentes constituem o fundamento para as relações sociais transnacionais. E o grupo familiar constitui-se um eixo de organização social prioritário na vida das migrantes, cuja importância cresce neste contexto transnacional. ${ }^{116}$

E ainda a perspectiva transnacional qualifica a hipótese da migração como o resultado de uma decisão familiar, uma vez que leva em conta os efeitos e percepções diferenciadas do fato migratório e impõe desafios de novos arranjos familiares, amparados pela multiplicação de possibilidades de comunicação.

A separação é um dos obstáculos que influi na decisão de migrar. Em muitos casos tratam-se de separações transitórias que podem findar com o retorno do migrante após concluir o seu objetivo econômico, ou com a reagrupação familiar. Em outros casos, a reunificação não se completa e a separação geográfica é mantida por períodos mais longos.

Dora vive há mais de uma década separada de seu marido, com seus três filhos, e a não perspectiva de reunificação já não lhe causa mais incômodo. No entanto, anualmente ela se encontra com o seu companheiro, pelo qual afirma sentir muito carinho, alternando entre visitas ao Paraguai e recebendo-o em São Paulo,

A migração sempre configurou famílias transnacionais; no sentido da separação física e geográfica, esse não é um fenômeno novo. O que a diferencia e a marca neste século XXI são os avanços tecnológicos de informação, comunicação e transporte. Estes avanços reduzem o distanciamento que envolve a separação por um longo período de tempo, bem como permitem que a tomada de decisões possam ser compartilhadas de forma rotineira e em tempo real.

\footnotetext{
${ }^{115}$ ZONTINI, E. 'Transnational families', Sloan Work and Family Research Network Encyclopedia Entry. Disponível em: <https://workfamily.sas.upenn.edu/wfrn-repo/object/be4md40po6iq2g3x>.

${ }^{116}$ ARIZA, Marina. Migración, familia y transnacionalidad en el contexto de la globalizacion: algunos puntos de reflexión. In: Revista Mexicana de Sociología, vol. 64, nº 4, 2002. p. 53-84.
} 
Outra diferença, conforme Parrela e Cavalcanti, ${ }^{117}$ são as mulheres migrantes "chefes de família", que têm seu processo migratório formatado pela pobreza e falta de oportunidades. Nestes casos, a figura materna é indissociável da dimensão da mãe cuidadora e a que sustenta a família economicamente. A migração aqui faz as vezes de elemento de continuidade do papel atribuído à mulher exposta ao custo da desterritorialização.

Claudia Pedone assinala que as estruturas familiares transnacionais vinculadas à feminização dos fluxos migratórios podem gerar estigmas e preconceitos, por não obedecer à tradicional unidade familiar. Para ela, muitos discursos políticos, acadêmicos e até midiáticos relacionam a separação da família como o principal desencadeador de fatores negativos, como o aumento do número de divórcios, alcoolismo masculino, gravidez na adolescência, entre outros. ${ }^{118}$ Bernhard, Landolt e Goldring ${ }^{119}$ dialogam com Pedone, ressaltando que as famílias transnacionais não constituem unidades familiares deficientes ou defeituosas em si apenas por transgredir o modelo de família tradicional, nuclear, situada em um espaço físico.

De fato, dos relatos trazidos por esta dissertação, a necessidade de viver geograficamente longe da família não demonstra que vivem em famílias desestruturadas devido à distância. Elas, que decidiram morar fora do país em que nasceram, já fogem de um modelo tradicional. Nancy procurou o "não tradicional" ao querer viver uma aventura em São Paulo. Dora é casada, mesmo estando mais de dez anos vivendo em país diferente que seu marido. Luzetânia é o pilar de sua família, mesmo sendo a única fora da Bolívia.

No entanto, Parrela e Cavalcanti ${ }^{120}$ afirmam que não há como evitar os custos emocionais que passam as famílias e seus membros. E a evolução, propagação, alcance e impacto das práticas familiares transnacionais não estão determinados a priori, mas são reflexos das conjunturas econômicas, políticas e sociais que estão interligados, seja nos

\footnotetext{
${ }^{117}$ PARELLA, Sonia e CAVALCANTI, Leonardo. Dinámicas Familiares Transnacionales y Migración Femenina: El Caso De Las Migrantes Bolivianas En España. (2008). Disponível em:

$<$ http://webs.uvigo.es/xenero/profesorado/sonia_parella/migracion.pdf. Acesso em: 05 jan. 2014.

118 PEDONE, Claudia "Varones aventureros" vs. "Madres que abandonan": reconstrucción de las relaciones familiares a partir de las migración ecuatoriana. In: REMHU. Revista Interdisciplinar da Mobilidade Humana, $n^{\circ}$ 30, 2008. pp. 45-64.

${ }^{119}$ BERNHARD, Judith K.; LANDOLT, Patricia e GOLDRING, Luin,.Transnational, Multi-Local Motherhood: Experiences of Separation and Reunification among Latin American Families in Canada. In: Early Childhood Education Publications and Research. Paper 6, 2005.

${ }^{120}$ BERNHARD et al., op.cit., p. 11.
} 
países de origem, como nos de destino.

Em um sentido mais restrito, a gestão dos vínculos familiares na transnacionalidade e os seus impactos são condicionados aos arranjos familiares e suas redes, assim como o grau de comunicação que essas migrantes estabelecem e mantêm com sua família. ${ }^{121}$ Fator importante ainda são as remessas de dinheiro, para cobrir os gastos com cuidados, como a educação e saúde.

Já em sentido mais amplo, os lugares de destino, como no caso do Brasil, também não estão à margem de seus impactos. Exemplo são as crescentes políticas migratórias acompanhadas dos serviços sociais. Com o acordo de livre residência do MERCOSUL e países associados, ${ }^{122}$ as pessoas nascidas na Argentina, Bolívia, Brasil, Chile, Paraguai, Peru e Uruguai podem residir em um destes países e, uma vez portadoras do documento que permite a residência, podem sair do país para visitar familiares sempre que possível. Essa prática não era regulamentada até 2009 , o que podia determinar o tempo de separação entre os integrantes da família transnacional.

A inexistência de um acordo bilateral entre Brasil e Paraguai até 2009 fez com que Dora tivesse que enfrentar muitas barreiras, que poderia ter custado o tratamento do filho. $\mathrm{E}$ para garanti-lo, ela não hesitou em burlar a fronteira.

Mesmo já protegida pelo acordo, ela teve muitos problemas para conseguir os documentos para ela e para os filhos: informações desencontradas pela Polícia Federal e o consulado de seu país, taxas muito caras, documentos com prazo de validade. E após obter o número do seu Registro Nacional de Estrangeiros, quase dez anos depois de chegar ao Brasil, ela pode receber os benefícios sócio-assistenciais, como Bolsa Família, e vale transporte para levar seus filhos para fazer tratamento.

A falta de documentos também foi obstáculo para Cecília e sua família. O Brasil também não tinha acordo bilateral de regularização migratória com o Peru até 2011, quando o país aderiu ao Acordo MERCOSUL. Por falta de acesso à informação, ela não sabia que

${ }^{121}$ HERRERA, Gioconda. Mujeres ecuatorianas en el trabajo doméstico en España. In: NOVICK, Susana (Org.). Las migraciones en América Latina. Buenos Aires: Consejo Latinoamericano de Ciencias Sociales - CLACSO, 2008.

${ }_{122}$ Decretos no $6.964 / 2009$ e n $^{\circ} 6.975 / 2009$. 
seus filhos, nascidos na Argentina, poderiam gozar do acordo bilateral entre Brasil e Argentina. ${ }^{123}$ Com a Lei de Anistia Migratória, ela deu entrada a todos os documentos, mas teve dificuldades em renová-los por questões burocráticas e informações desencontradas, o que poderia custar o estudo dos filhos.

São exemplos que moldam a construção social de significados e definições de papéis familiares. Estes rearranjos e adaptações exigidos pela vida transnacional para as famílias dessas migrantes que iniciam o processo migratório de suas famílias mostram como são as estratégias que geram os processos de mudanças a que estão condicionadas.

A perspectiva transnacional sobre a migração é relevante, devido às forças da globalização e seus impactos sobre a mobilidade. A facilidade em se conectar a duas ou mais realidades está mais fácil e torna esta dimensão familiar mais plausível. Para além dos benefícios que podem implicar os processos migratórios para a família, como o financeiro e o social, os custos emocionais são altos, ainda mais quando se trata da migração que tem a mulher como protagonista, que gera a necessidade de reestruturação das tarefas da reprodução social dos países de origem, socialmente atribuídas ao papel da mulher.

Mas as estratégias da condução desta vida transnacional também dependem das condições de trabalho. do respeito aos direitos laborais e da regularização migratória dos e das migrantes na sociedade de destino, determinando as práticas e configurações destas famílias entre dois países. Como consequência, influem diretamente na maneira de gerir as relações familiares à distância e seus impactos.

\subsection{Elas que trabalham}

Em comum às três das narrativas apresentadas estão histórias que têm o trabalho forçado e degradante como linhas mestras. O tema aparece de forma marcante e pontual para Nancy, como uma lembrança para Cristina, e para Luzetânia é o principal motivo para a sua migração.

${ }^{123}$ MINISTÉRIOS DE ESTADO DAS RELAÇÕES EXTERIORES E DA JUSTIÇA. Portaria Interministerial de 28 de agosto de 2006. Dá execução ao Acordo, por troca de Notas, entre a República Federativa do Brasil e a República Argentina, para Implementação entre si do Acordo sobre Residência para Nacionais dos Estados Partes do Mercosul e seu anexo. Diário Oficial da União, Seção I, No 166, terça-feira, 29 de agosto de 2006, p. 66-67. 
Nestas falas também está presente a interpretação subjetiva sobre o que seus países representam: um lugar periférico, de onde se deve sair para prosperar.

Saskia Sassen afirma que o capital é que migra, e com ele leva os trabalhadores. Em 1991 ela cunhou o termo global city, ${ }^{124}$ relacionado à ideia de globalização e a de que cidades como Nova Iorque, Tóquio e Londres movem a economia global. Segundo ela, por serem centros do capital, estas cidades aglutinam promessas de boas condições de vida, e tornam-se polos de esperança para aqueles que não encontram meios de sobrevivência na cidade.

Conforme sua análise, nas duas últimas décadas do século XX, as grandes indústrias, que costumavam contar com mão de obra numerosa e razoavelmente remunerada para uma produção em massa, substituíram-na por trabalho subcontratado, para poder flexibilizar a produção, o que é chamado de terceirização.

[...] boa parte do trabalho que no passado se caracterizava como produção em massa, padronizada, hoje se caracteriza cada vez mais pela flexibilização, por trabalhos realizados mediante encomenda, por redes de subempreiteiros e pela informalização. ${ }^{125}$

Este rearranjo retirou os cargos que não compunham a base produtiva da empresa, como segurança, limpeza e refeitório, e que passaram a compor estruturas de serviços à parte, descoladas do padrão de salário principal, reduzindo os custos finais da produção.

As migrações representam um importante mecanismo de suprimento de mão de obra pouco qualificada e têm forte relação com o aumento da vulnerabilidade e da informalidade do trabalho, por gerarem baixo custo para grandes empresas que não têm mais relações diretas com os trabalhadores, isentando-se assim de garantir as condições trabalhistas.

Os migrantes são boa parte daqueles que realizam esse tipo de trabalho. O Brasil, por apresentar um desempenho positivo de sua economia, pode ter se tornado um "polo de esperança", como diz Sassen. E a produção têxtil da região metropolitana de São Paulo tem

\footnotetext{
${ }^{124}$ SASSEN, Saskia. The Global City. New York, London, Tokyo. Princeton, New Jersey: Princeton University Press, 1991.

${ }^{125}$ Ibidem, p.131.
} 
sido sustentada pelo trabalho precário de migrantes sul-americanos.

Os números exatos destes trabalhadores são desconhecidos, já que se trata de trabalho informal, mas dezenas de milhares participam ativamente dessa cadeia produtiva. $\mathrm{E}$ no pano de fundo deste cenário encontram-se diversos trabalhadores migrantes, vindos de países como Bolívia, Paraguai e Peru, que trabalham por mais de catorze horas para receber valores próximos ao salário mínimo e sem as mais básicas condições de segurança e saúde.

Muitas vezes, para chegar à São Paulo, esses trabalhadores migrantes contraem dívidas que são já descontadas dos salários baixos, ocasionando situações de servidão e de restrição da liberdade de locomoção. Essa situação é agravada em virtude do desconhecimento das leis nacionais e da falta dos documentos brasileiros.

Corroborando Boaventura de Sousa Santos ao dizer que "colonialismo é capitalismo", ${ }^{126}$ as "maravilhas" da globalização servem para ocultar a outra face do fenômeno: a extrema pulverização da produção têxtil aumenta a concorrência entre as oficinas de costura e rebaixa os preços a um nível insuportável para a maior parte delas. $\mathrm{Ou}$ seja, a concorrência neste caso não traz uma melhoria do produto, e, sim, mais precarização.

Luzetânia e Nancy participaram do "sistema de suor", que representa o sistema no qual os locais de trabalho confundem-se com as residências e os obreiros trabalham sob condições extremas de opressão, por salários miseráveis, jornadas demasiadamente extensas e exaustivas, condições de saúde e segurança precárias ou inexistentes.

A "fábrica de suor" corresponde ao local onde se desenvolve o sistema do suor, e significa uma mistura entre casa e oficina de trabalho, ou melhor: a oficina como a extensão do estabelecimento fabril, mas sem as condições adequadas tanto de proteção como de controle, já que é a continuação da residência. A fábrica de suor se caracteriza por pessoas ou famílias convivendo aglomeradas, sem as necessárias condições de higiene e segurança no trabalho, trabalhando longas jornadas, além do pagamento por peça a valores irrisórios. $^{127}$

E o fluxo migratório se insere neste contexto como um mecanismo de produção e

\footnotetext{
${ }^{126}$ SANTOS, Boaventura de Sousa. Renovar a teoria crítica e reinventar a emancipação social. São Paulo: Boitempo, 2007. p.51.

${ }^{127}$ Optamos por traduzir livremente os termos em inglês sweating system e sweatshop como "sistema de suor" e "fábrica de suor", para dar a dimensão da carga exploratória que as pessoas submetidas a este sistema sofrem.
} 
reprodução de desigualdades. A subcontratação de trabalhadores migrantes para o suprimento da demanda nas oficinas é a fonte da taxa de exploração da mão de obra, já que, por esse mecanismo, a indústria importa trabalhadores destituídos da condição de cidadãos, ou seja, fora do escopo dos direitos trabalhistas.

Nesta esteira e pensando na produtividade, o dono da casa, que também é o dono da oficina, não se preocupa com os direitos fundamentais do trabalhador, e assume, além do papel de patrão, o papel de protetor. Isso faz com que se demore a perceber a exploração no trabalho. Em alguns casos, como pudemos perceber nas histórias de vida das duas bolivianas aqui transcriadas, a exploração só foi levada em conta quando a situação de falta de pagamento por parte do patrão ficou insustentável.

Trechos de uma reportagem da ONG Repórter Brasil dão a dimensão da cadeia produtiva da rede espanhola Zara, que inclui oficinas flagradas com trabalho análogo a escravidão:

Nem uma, nem duas. Por três vezes, equipes de fiscalização trabalhista flagraram trabalhadores estrangeiros submetidos a condições análogas à escravidão produzindo peças de roupa da badalada marca internacional Zara, do grupo espanhol Inditex.

$\mathrm{Na}$ mais recente operação que vasculhou subcontratadas de uma das principais "fornecedoras" da rede, 15 pessoas, incluindo uma adolescente de apenas 14 anos, foram libertadas de escravidão contemporânea de duas oficinas - uma localizada no Centro da capital paulista e outra na Zona Norte.

O quadro encontrado pelos agentes do poder público, e acompanhado pela Repórter Brasil, incluía contratações completamente ilegais, trabalho infantil, condições degradantes, jornadas exaustivas de até $16 \mathrm{~h}$ diárias e cerceamento de liberdade (seja pela cobrança e desconto irregular de dívidas dos salários, o truck system, seja pela proibição de deixar o local de trabalho sem prévia autorização). Apesar do clima de medo, um dos trabalhadores explorados confirmou que só conseguia sair da casa com a 
autorização do dono da oficina, concedida apenas em casos urgentes, como quando teve de levar seu filho às pressas ao médico. ${ }^{128}$

O fato de os donos das oficinas explorarem os seus empregados não significa que eles também não sejam explorados. Aliás, o papel do dono da oficina não é exatamente explorar a mão de obra de seus empregados, muitas vezes compatriotas, e sim gerenciar a produção e a mão de obra, dependendo financeiramente da empresa de quem recebeu a encomenda. Suas jornadas de trabalho são tão grandes como as dos empregados das oficinas, o que também mascara o sentimento de que são exploradores.

E como resultado, no valor final da mercadoria não estão computados os custos necessários nem à subsistência dos trabalhadores, nem à garantia dos seus direitos trabalhistas. Conforme a reportagem:

Para Giuliana [auditora fiscal], a superexploração dos empregados, que têm seus direitos laborais e previdenciários negados, é motivada essencialmente pelo aumento das margens de lucro. "Com isso, há uma redução do preço dos produtos, caracterizando o dumping social, uma vantagem econômica indevida no contexto da competição no mercado, uma concorrência desleal".

[...] Para cada peça feita, o dono da oficina recebia $\mathrm{R} \$$ 7. Os costureiros declararam que recebiam, em média, $\mathrm{R} \$ 2$ por peça costurada. No dia seguinte à ação, 27 de junho [2011], a reportagem foi até uma loja da Zara na Zona Oeste de São Paulo (SP), e encontrou uma blusa semelhante, fabricada originalmente na Espanha, sendo vendida por R\$139.

Neste caso Zara, que tomou proporção grande, graças também à divulgação em redes sociais da internet, as empresas contratadas por ela, ou seja, as intermediárias, realizam as etapas de produção, maquiando a relação entre as lojas finais e a cadeia produtiva, e isentam as empresas formais da administração e dos custos reais da mão de obra, passando a responsabilidade para as pequenas fábricas de suor.

\footnotetext{
${ }^{128}$ PYL, Bianca e HASHIZUME, Maurício. Roupas da Zara são fabricadas com mão de obra escrava. Repórter Brasil, São Paulo, 16 ago. 2011. Disponível em: <http://reporterbrasil.org.br/2011/08/roupas-dazara-sao-fabricadas-com-mao-de-obra-escrava/>.
} 
Ou seja: sistema de suor é a expressão do trabalho forçado urbano.

\subsubsection{Trabalho forçado}

O trabalho forçado, conforme a Convenção $n^{\circ} 29^{129}$ da Organização Internacional do Trabalho (OIT), ${ }^{130}$ é "Todo trabalho ou serviço exigido de um indivíduo sob ameaça de uma pena qualquer e para o qual o indivíduo não se apresentou voluntariamente". Para ser caracterizado, o trabalho deve ser exigido sob ameaça de punição (utilização de violência ou perda de direitos e privilégios), ou exercido involuntariamente, ou implica em uma restrição de liberdade pessoal e na utilização da coação.

Portanto, ele não se confunde com baixos salários ou condições precárias de trabalho, e sim com quando há uma violação de direitos em situações como: rapto, confinamento no local de trabalho, ordem para trabalhar acompanhada por uma ameaça de punição, dívidas induzidas ou fraudulentas, engano sobre condições de trabalho, retenção ou não pagamento de salários, retenção de documentos e tráfico de pessoas.

Pode estar presente na cadeia produtiva de empresas grandes e modernas, nacionais e multinacionais. E 125 anos depois de abolido o sistema escravagista da exploração de mão de obra no Brasil, ainda persistem suas consequências, com as quais conviveram os migrantes europeus nas fazendas de café no sudeste e os "soldados" da borracha no norte, no século XIX, e com as quais convivem os cortadores de cana-de-açúcar do nordeste, trabalhadores nas fazendas de gado do centro-oeste, e os que trabalham no agronegócio, no desmatamento, em casas de prostituição e em oficinas de costura.

Em comum possuem a desigualdade social, a falta de oportunidades e a condição de vulnerabilidade, que culminam com o cerceamento da liberdade.

E ainda: um trabalhador explorado pode não se sentir explorado, o que dificulta

\footnotetext{
${ }^{129}$ Disponível em: <http://www.oit.org.br/sites/all/forced_labour/oit/convencoes/conv_29.pdf>. Acesso em 14 ago. 2013.

${ }^{130}$ Agência das Nações Unidas, com estrutura tripartite, composta de representantes de governos e de organizações de empregadores e de trabalhadores, que tem por missão promover oportunidades para que homens e mulheres possam ter acesso a um trabalho decente e produtivo, em condições de liberdade, equidade, segurança e dignidade.
} 
definir a situação como exploração ou algo pior. Além disso, o medo do estigma pode fazer com que a pessoa não queira ser identificado como explorada.

No relato de Cristina, ela entende por submissão a exploração no trabalho pela qual ela e seus patrícios passam. E justifica que a necessidade do salário associada à falta de acesso aos direitos trabalhistas faz com que eles se calem diante das violações de direitos. As humilhações, violações e jornadas exaustivas não são reclamadas, pois o pequeno salário prometido é importante para a sobrevivência do empregado e muitas vezes de toda a sua família.

Seguindo uma lógica bem perversa da divisão do trabalho, ela diz sobre os seus patrões que "é muito triste esta dominação que os coreanos fazem, porque eles só querem produzir e produzir, não te dão liberdade para descansar, estar com sua família, saber o que se tem em São Paulo, a arte, a própria cidade”. E ainda na linha marxista, ela diz que neste sistema de trabalho para que os donos de oficina tenham mais dinheiro, os migrantes "perdem a oportunidade de serem pessoas".

Em sua entrevista, Cristina não relata as violações sofridas com muitos detalhes. Ela se preocupa mais em falar que teve que passar por isso como um ensinamento, uma lição, e enxerga sua experiência de forma positiva, por ter tido ciência de seus direitos e por saber lidar com situações deste tipo. Mas sabe que, por vezes, a necessidade, ou falta de oportunidades, impede que muitas pessoas em situação de exploração possam fazer com que seus direitos sejam cumpridos: "[...] sei que muitas pessoas não pensam da mesma forma, vão pesar que precisam do dinheiro, que tem uma família para sustentar, que não é tão ruim como se diz".

Exploradores, seja em qualquer parte da cadeia produtiva - empregadores ou intermediários -, não violam as leis nacionais de uma forma explícita. A exploração pode ser estruturada a partir de práticas de trabalho. A produção pulverizada das peças propicia agilidade na entrega e transfere os custos empresariais e trabalhistas para a ponta da cadeia, acarretando uma espécie de concorrência às avessas, pois se uma determinada oficina não aceita produzir peças a um determinado valor, outra certamente aceitará.

As fiscalizações da Superintendência Regional do Trabalho e Emprego acabam descortinando estes feitos, partindo do princípio da responsabilidade objetiva do dono da 
cadeia produtiva, como consignado no parágrafo único do artigo 927 do Código Civil: "Haverá obrigação de reparar o dano, independentemente de culpa, nos casos especificados em lei, ou quando a atividade normalmente desenvolvida pelo autor do dano implicar, por sua natureza, risco para os direitos de outrem".

Conforme auditor do Ministério do Trabalho e Emprego, em um caso de flagrante de trabalho escravo envolvendo um grande magazine: "a Pernambucanas não pode alegar que apenas vende - e não produz - peças de vestuário. Os atos diretivos e empresariais são das Pernambucanas. É a empresa que determina a tendência, faz o controle de qualidade de cada peça, estipula o preço e o prazo que as peças devem ser entregues", ${ }^{131}$ ou seja, a empresa final deve ter a responsabilidade por toda a sua cadeia produtiva.

As formas contemporâneas de escravidão vão além da baixa remuneração e do trabalho sob condições precárias. A existência do crime está no nosso ordenamento jurídico desde 1940, através de um então genérico artigo $149^{132}$ do Código Penal. A obrigação de garantir os direitos trabalhistas só foi editada em 1963, com o Estatuto do Trabalhador Rural, com previsão de normas de proteção a essa categoria de obreiros, vinte anos depois da Consolidação das Leis do Trabalho. A lei 5889/73 substituiu o Estatuto, estendendo os direitos dos trabalhadores urbanos aos trabalhadores rurais com algumas peculiaridades, uma vez que a igualdade jurídica só veio com a Constituição Federal de 1988.

Apenas em 1971 foi feita a primeira denúncia pública de trabalho escravo nos estados do Mato Grosso, Pará e Goiás, através da carta pastoral "Uma Igreja da Amazônia em conflito com o latifúndio e a marginalização social”, pelo bispo D. Pedro Casaldáliga. Ameaçado e fortemente criticado, foi o primeiro texto público a tratar do tema e expor a realidade dos trabalhadores submetidos ao trabalho escravo. Em 1975, foi criada a primeira organização não governamental voltada para a questão, a Comissão Pastoral da Terra (CPT), ligada à Conferência Nacional de Bispos do Brasil (CNBB).

As primeiras tentativas governamentais para lidar com o problema aconteceram entre os anos de 1985 e 1986, com protocolos de intenções entre os Ministérios do Trabalho, da Reforma e Desenvolvimento Agrário e da Justiça para conjugar esforços visando reprimir

\footnotetext{
${ }^{131}$ PYL, Bianca. Trabalho escravo é flagrado na cadeia da Pernambucanas. Repórter Brasil, São Paulo, 02 abr. 2011. Disponível em: <http://reporterbrasil.org.br/2011/04/trabalho-escravo-e-flagrado-na-cadeia-dapernambucanas/>.

${ }^{132}$ Redação antiga do art. 149 - "Reduzir alguém a condição análoga à de escravo: Pena - reclusão, de 2 (dois) a 8 (oito) anos."
} 
violações aos direitos sociais dos trabalhadores rurais dos estados do Pará, Maranhão e Goiás. $^{133}$

$\mathrm{Na}$ década de 90, diversas denúncias contra o Estado brasileiro foram protocoladas em organismos internacionais, como as Nações Unidas, a Organização Internacional do Trabalho e a Organização dos Estados Americanos. Este último, ensejado pelo caso José Pereira, juntamente com a Comissão Interamericana de Direitos Humanos (CIDH). Para evitar uma condenação, em 2003 o Brasil aceitou termo de solução amistosa, em que assumiu uma série de compromissos para o combate ao trabalho escravo. Iniciou-se uma campanha de combate ao trabalho escravo que culminou em 1995 com o reconhecimento público pelo Governo Brasileiro da existência de trabalho escravo. ${ }^{134}$

A partir daí, começou a ser estruturada a política brasileira contra a escravidão contemporânea, e, em 2003, foi instituída a Comissão Nacional de Erradicação do Trabalho Escravo (CONATRAE), integrada por diversos representantes de governo, de trabalhadores, de empregadores e da sociedade civil. O documento norteador é o Plano Nacional de Erradicação do Trabalho Escravo (PNETE), adotado em 2003, e avaliado e revisto em 2008, o que gerou o $2^{\circ}$ PNETE.

Reflexo do PNETE foi a alteração do artigo 149 do Código Penal, pela Lei ${ }^{\circ}$ $10.803 / 03$, que fixa tipificação mais precisa das condutas que caracterizam o crime. Sua nova redação diz:

Art. 149. Reduzir alguém a condição análoga à de escravo, quer submetendo-o a trabalhos forçados ou a jornada exaustiva, quer sujeitandoo a condições degradantes de trabalho, quer restringindo, por qualquer meio, sua locomoção em razão de dívida contraída com o empregador ou preposto.

Este novo texto explicita quais são os elementos que determinam trabalho análogo ao de escravo: 1. condições degradantes de trabalho, que excluem o trabalhador de sua dignidade; 2. jornada exaustiva, que impede o trabalhador de se recuperar fisicamente e ter uma vida social; 3. trabalho forçado, o que enseja manter a pessoa no serviço através de

\footnotetext{
${ }^{133}$ Disponível em:

$<$ http://portal.mte.gov.br/data/files/8A7C816A350AC882013543FDF74540AB/retrospec_trab_escravo.pdf $>$. Acesso em: 09 ago. 2013.

${ }^{134}$ Ibidem.
} 
fraudes, isolamento geográfico, ameaças e violências físicas e psicológicas; e 4. servidão por dívida, o que representa fazer com que o trabalhador contraia ilegalmente um débito e seja preso a ele.

Em sua fala, Nancy despende um bom tempo contando sobre seu trabalho e sobre a relação de exploração vivida na oficina de costura onde morou e trabalhou. Sua vinda para São Paulo foi motivada pelo convite do irmão de sua amiga, que, como ela, teve toda a sua viagem financiada pelo dono da oficina. Esse ato, entendido muitas vezes como um "favor", é um dos elementos característicos do trabalho análogo ao de escravo: a servidão por dívida.

No trabalho escravo contemporâneo, o patrão não exerce um direito de propriedade, mas sim de uso e abuso, o que muitas vezes se revela pior, pois ele não se responsabiliza pela "conservação" deste patrimônio ou a pela reprodução de sua prole. Ao contrário, descarta-o quando não lhe serve mais, ou quando encontra quem faça o serviço por um preço mais baixo.

Grilhões e correntes não são mais o meio comum de subjugar a liberdade de outrem: trabalhadores sem terra e sem alternativa, vítimas de promessas, migram em busca de sustento a qualquer preço. Trabalho degradante, jornada exaustiva, dívida fabricada, humilhações, ameaças e violência, junto com o isolamento, são as correntes eficazes do seu cativeiro. Nancy vivenciou esses tipos de violência.

Em seu relato, ela revela artimanhas de exploradores, os quais ela denomina de “espertinhos". Ela conta que, para aumentar os lucros do dono da oficina, existe a preferência por empregar migrantes que recém chegaram em vez daqueles que já estão aqui estabelecidos. Os primeiros são empregados mesmo sem saberem costurar, pois o processo de aprendizado não é tão rápido, o que faz com que a dívida aumente, uma vez que o empregado vai demorar mais tempo para começar a produzir peças, o que consequentemente aumenta o lucro do dono da oficina. Ainda, por terem acabado de chegar, não sabem quanto é o salário e os custos de vida na cidade de São Paulo. Segundo ela, os donos de oficina que exploram não querem os que já estão aqui, porque "é encrenca", ou seja, eles têm acesso à informação, uma vez que já passaram pela experiência por qual ela passou, e também por conhecerem seus direitos.

Em seus três anos trabalhando para o mesmo patrão, ela demorou para se sentir 
explorada, ou com sua liberdade cerceada. Quem trabalha em situações degradantes, com a possibilidade de estar sendo sujeito à exploração, tem tendência a trabalhar em setores em que o salário é baixo, onde as margens de lucros são pequenas, a mão de obra compõe grande parte do custo de produção, e o local de trabalho não é num lugar público, mas privado, como casas, ${ }^{135}$ onde é difícil a fiscalização por se tratar de domicílio. ${ }^{136}$

A condição de migrante sem documentos, irregularmente trabalhando, e que depende do seu empregador para se alimentar e morar, é outra característica do trabalho análogo ao de escravo. Casos como o de Cristina, Nancy e Luzetânia revelam ainda um ciclo que as deixam triplamente vulnerável: trabalho precário, exercido por mulher migrante, sem documentos. ${ }^{137}$

Não estar com o seu status migratório regular é outro artifício usado pelo explorador. A ameaça de deportação por não ter documentos é uma maneira de impedir que se procure direitos. Em plena vigência do Acordo de Livre Residência do MERCOSUL e países associados, ${ }^{138}$ Nancy e Luzetânia viveram sob o medo de serem denunciadas e deportadas.

A falta de uma política migratória no país de origem e de destino, e como consequência a falta de informação sobre o país e a cidade em que vai viver, opera a favor do explorador. Com a desculpa de viver há mais tempo no país, o patrão de Nancy a convenceu a deixar o seu salário com ele, por insinuar que São Paulo é um local perigoso, e o seu dinheiro poderia ficar seguro nas mãos dele. Sem deixar alternativas, lhe foi proposta a possibilidade de receber aos poucos, em forma de "vales". Resultado: em um ano de trabalho, ela não recebeu nada por seu trabalho, não ajudou a mãe na Bolívia conforme sua ideia inicial, e não questionou seu patrício que mantinha o seu ordenado quando ele deu uma desculpa qualquer para não pagá-lo.

Aos poucos, a confiança que tinha no seu empregador foi dando espaço a desconfianças. Desde a percepção de que a esposa de seu patrão também tinha uma relação de subordinação e temor ao marido, até a compreensão de que ele não honrava suas dívidas

${ }^{135}$ GAATW (Ed.). Beyond Borders: Exploring Links between Trafficking and Labour. Working Paper Series. Bangkok: GAATW, 2010. p. 8.

${ }^{136}$ Segundo o artigo $5^{\circ}$ inciso XI da Constituição Federal, “a casa é asilo inviolável do indivíduo, ninguém nela podendo penetrar sem consentimento do morador, salvo em caso de flagrante delito ou desastre, ou para prestar socorro, ou, durante o dia, por determinação judicial”; o que significa que qualquer físcalização só pode ser feita com denúncia.

${ }^{137}$ GAATW (Ed.), 2010, op. cit., p. 10.

${ }^{138}$ Decretos no $^{\circ} 6.964 / 2009$ e $n^{\circ} 6.975 / 2009$. 
com outros credores.

E frente à justificativa de que ele não tinha dinheiro, causava estranheza que mesmo assim ele adquiria bens, como um carro, ou o patrocínio de bebidas em festas devocionais. Segundo Silva, estas festas remontam à época pré-colombiana, quando os metais preciosos eram levados no lombo de animais para serem oferecidos às divindades incaicas. Esta tradição ainda é vigente, mesmo fora da Bolívia, e os devotos oferecem suas riquezas que não são mais obtidas através da terra (ou da Pachamama), mas sim pelo do trabalho superexplorado nas oficinas de costura. ${ }^{139}$

Mesmo com quase três anos trabalhando sem ganhar efetivamente um salário, Nancy não se sente explorada e ainda o usa como espelho, e não a sua esposa, ao insistentemente argumentar que como ele, ela também quer constituir uma família e ter sua oficina de costura. Seu único modelo de trabalho envolve a repetição deste ciclo exploratório.

Filosofa que tropeços são necessários para evoluir. Em suas palavras: "Mas quando saímos do colo de nossa mãe, aí que temos que nos virar, temos que aprender a se virar na vida. E foi por isso que eu quis vir para o Brasil, se eu ficasse na Bolívia eu não ia aprender as coisas, experimentar".

A decisão de migrar de Luzetânia foi uma decisão familiar, tomada frente à falta de recursos financeiros que ela e sua família passavam. Aproveitando-se desta frágil situação, sua vizinha, que já devia bastante dinheiro para ela e sua mãe, a convida a trabalhar em sua oficina de costura aqui em São Paulo.

O convite veio sem mais detalhamentos de como seria a vida e o emprego no Brasil, artifício que, aliado à falta de acesso à informação sobre oportunidades e direitos, custos, benefícios e passos necessário para migrar de forma regular e com segurança, selou a situação de dependência. A promessa veio como garantia de pagamento da dívida e de que iria ganhar muito dinheiro costurando em São Paulo.

A falta de informação, aliada à necessidade de prover a sua família, fez com que Luzetânia passasse pelo o que ela disse ter sido uma das piores experiências de sua vida. $\mathrm{Na}$

${ }^{139}$ SILVA, Sidney Antonio da. Virgem/Mãe/Terra. Festas e tradições bolivianas na metrópole. São Paulo: Hucitec/Fapesp, 2003. 
fronteira da Bolívia, antes de fazer a travessia, ela foi alertada de que sem os documentos de autorização de viagem assinados pelo pai da criança, ela não poderia viajar. Seguindo a orientação da pessoa que a estava trazendo, ela pediu para uma pessoa do povoado vizinho levar o seu bebê, que ainda não tinha nome, para as suas irmãs.

Já instalada em São Paulo, a dona da oficina abriu um restaurante e ofereceu uma chance de Luzetânia ganhar ainda mais dinheiro: além de costurar, ela poderia cozinhar aos finais de semana, o que significava que ela trabalharia todos os dias. A proposta foi aceita, mas ela não recebeu o dinheiro prometido.

Ela conseguiu fugir da oficina, mas procurou ajuda não para reaver o dinheiro que lhe era devido, mas para resgatar a foto de seu filho, pois tinha medo que sua ex-patroa pudesse fazer alguma brujeria.

Sob a luz das normas internacionais de Direitos Humanos, Luzetânia foi vítima de Tráfico de Pessoas. O Tráfico inicia-se como um recrutamento ou movimentação entre lugares e termina com a exploração. Segundo o Protocolo Adicional à Convenção das Nações Unidas contra o Crime Organizado Transnacional Relativo à Prevenção, Repressão e Punição do Tráfico de Pessoas, em Especial Mulheres e Crianças (o Protocolo de Palermo, no Brasil ratificado como Decreto $\left.n^{\circ} 5.017 / 2004\right)$, a definição se dá em três partes: a ação, que é o recrutamento, transporte ou acolhimento de pessoas; os meios, que podem ser ameaça, uso de força, coação fraude, engano; e a finalidade, que é a exploração, seja a exploração sexual, o trabalho forçado, a escravidão ou a remoção de órgão. ${ }^{140}$

Diferente de contrabando de migrantes (smuggling, em inglês), ${ }^{141}$ que envolve o

\footnotetext{
${ }^{140}$ De acordo com o Protocolo de Palermo a definição de Tráfico de Pessoas está no artigo 3:

a) A expressão "tráfico de pessoas" significa o recrutamento, o transporte, a transferência, o alojamento ou o acolhimento de pessoas, recorrendo à ameaça ou uso da força ou a outras formas de coação, ao rapto, à fraude, ao engano, ao abuso de autoridade ou à situação de vulnerabilidade ou à entrega ou aceitação de pagamentos ou benefícios para obter o consentimento de uma pessoa que tenha autoridade sobre outra para fins de exploração. A exploração incluirá, no mínimo, a exploração da prostituição de outrem ou outras formas de exploração sexual, o trabalho ou serviços forçados, escravatura ou práticas similares à escravatura, a servidão ou a remoção de órgãos;

b) O consentimento dado pela vítima de tráfico de pessoas tendo em vista qualquer tipo de exploração descrito na alínea a) do presente Artigo será considerado irrelevante se tiver sido utilizado qualquer um dos meios referidos na alínea a);

${ }^{141} \mathrm{O}$ contrabando de migrantes é uma forma de traficar pessoas. Segundo o Protocolo Adicional à Convenção das Nações Unidas contra o Crime Organizado Transnacional, Relativo ao Combate ao Contrabando de Migrantes por via Terrestre, Marítima e Aérea, o contrabando de migrantes é a entrada ilegal de pessoas em
} 
conhecimento e o consentimento da pessoa contrabandeada sobre o ato criminoso, no tráfico de pessoas o consentimento da vítima é irrelevante para que seja caracterizado como tal.

O tráfico e o contrabando são fenômenos de migração irregular com vista à obtenção de lucro e envolvem pessoas que saem do país voluntariamente e estão sujeitas a condições de perigo e desconforto durante a viagem.

O contrabando refere-se a uma situação em que uma pessoa paga outra para the facilitar a passagem de fronteiras através de meios e processos ilegais. O tráfico de pessoas também pode implicar no auxílio à migração ilegal, mas se caracteriza pela exploração. No contrabando o pagamento é feito no início do processo ao smuggler (contrabandista), não criando uma interdependência entre as partes. Quem recorre a esta prática, a faz voluntariamente.

Já com o tráfico de pessoas pode haver engano, coação ou violência, e as pessoas que foram traficadas tendem a ser exploradas por um período de tempo, e o vínculo entre traficada e traficante é fortalecido pela dívida contraída pela viagem ao país (ou lugar) de destino.

O Protocolo de Palermo em seu artigo 3 dá a definição sobre o que é tráfico de pessoas e reconhece todas as suas formas abrindo novas perspectivas para o debate, por tratar o tráfico de pessoas como exploração, mercantilização de seres humanos, por não se restringir à questão da prostituição, por priorizar a atenção às vítimas e por ser um instrumento de direitos humanos. ${ }^{142}$

O contrabando finda com a chegada do migrante a seu destino, enquanto o tráfico de pessoas, após a chegada, envolve a exploração da vítima para obtenção de algum benefício ou lucro, por meio da exploração. O contrabando é um crime contra o Estado, enquanto o

países nos quais ela não possui residência nacional ou permanente, para aquisição de bens financeiros e outros ganhos materiais.

${ }_{142}$ SANTOS, Boaventura de Sousa; GOMES, Conceição; DUARTE, Madalena; BAGANHA, Maria Ioannis. Tráfico de Mulheres em Portugal para Fins de Exploração Sexual, Projecto CAIM - Cooperação.

Acção. Investigação. Mundivisão. Coimbra: Centro de Estudos Sociais (CES), 2007. 
tráfico é um crime contra a pessoa. ${ }^{143}$

Discussões têm sido aprofundadas e outras facetas são expostas, já que o tema permeia diversas áreas e toca questões profundas ligadas tanto ao mundo do trabalho, quanto às relações de gênero, passando pelos fluxos migratórios, estruturas legislativas nacionais e internacionais e correlações de forças entre os países.

Estabelecidas estas diferenças conceituais, observamos na narrativa de Luzetânia diversos elementos que caracterizam o tráfico de pessoas, quais sejam: o recrutamento, o transporte, o alojamento, engano, aceitação de pagamento, o vínculo com a traficante e principalmente a violação de direitos humanos, sobretudo em relação às condições de trabalho. Independente de seu consentimento e mesmo que no seu relato ela não se veja como vítima e nem tenha procurado ajuda por tal condição.

Com sua narrativa foi possível perceber a falta de políticas públicas e a fragilidade da rede de enfrentamento ao tráfico de pessoas em protegê-la. Não lhe foi solicitado comparecer à delegacia; ela foi levada, sem nenhuma assistência. A sua ex-patroa foi presa e logo solta, mas Luzetânia não se sente segura para sair de casa, com medo de vingança.

Ou seja, mesmo livre, recebendo mensalmente o salário num novo emprego, e mandando boa parte de sua renda para a sua família na Bolívia, ela se sente ameaçada.

E o sistema de enfrentamento do tráfico de pessoas está pronto para punir o crime, mas não para vê-lo como uma teia de fatores com ligações entre trabalho e migração. Qualquer ação que vise proteger vítimas deve levar em consideração contextos mais amplos, que incluem temas como relações de gênero, globalização e sistema de segurança.

A legislação brasileira também restringe o conceito de tráfico de pessoas. O Código Penal acompanhou os avanços na defesa dos direitos humanos e em 2005 ampliou o seu artigo 231 de tráfico internacional de mulheres para tráfico internacional de pessoas, e ainda criou o 231-A, que tratava do tráfico interno de pessoas. Em 2009 a redação foi alterada, destacando que ambos os crimes são "para fim de exploração sexual”.

\footnotetext{
${ }^{143}$ NOVAES, Marina M. Negotiating Rights at the Workplace. In: GAATW INTERNATIONAL MEMBERS CONGRESS AND CONFERENCE (IMCC). Bangkok, Tailândia, julho de 2010.
} 
Ao invés de aplicar o crime de tráfico de uma forma ampla, incluindo o a exploração de trabalho e a remoção de órgãos, o legislador brasileiro restringiu a definição para as pessoas que trabalham com sexo ou foram exploradas sexualmente.

De outro lado, categorizar migrantes que são explorados em seu trabalho como traficados pode resultar em "danos colaterais", como a restrição para a migração, ou deportação. ${ }^{144}$ Como exemplo, estudo da ONG ASBRAD ${ }^{145}$ aponta que as políticas de enfrentamento ao tráfico de pessoas inadmitiu muitas mulheres brasileiras que tentavam migrar para países da Europa, entrando por Portugal e Espanha.

\subsubsection{A relação entre as formas de trabalho forçado}

A interposição entre o tráfico de pessoas e o trabalho realizado em condição análoga à de escravo deve ser considerada a partir da premissa que a exploração do trabalho escravo é uma das principais finalidades do mercado clandestino caracterizado pelo tráfico de pessoas: onde há trabalho escravo, necessariamente estará configurado o tráfico de pessoas.

Os dois conceitos, no entanto, são compreendidos de forma separada e sem conexão. Tal fato, no Brasil, pode ser atribuído, por exemplo, ao desenvolvimento em paralelo dos dois movimentos: o antiescravista, mais antigo e consolidado, e antitráfico, mais recente e ainda em construção. Pode-se atribui-los também à configuração tipológica do crime de tráfico de pessoas em nosso ordenamento, que prevê apenas a exploração sexual. Outro motivo é a polissemia inerente aos termos.

Traficar adquire diversos sentidos, de acordo com o interlocutor, seus valores, e o propósito de uso da palavra. Alguns entendem tráfico de pessoas como aquele que ocorre com mulheres que são obrigadas a se prostituir no exterior. Reduzem, portanto, o tráfico de pessoas à exploração sexual. Outros entendem tráfico de pessoas como um movimento ilegal de migrantes entre fronteiras. Reduzem, portanto, o tráfico de pessoas à movimentação ilegal de migrantes. Ainda há aqueles que compreendem que o tráfico de

${ }^{144}$ GAATW (Ed.). Collateral Damage: The Impact of Anti-Trafficking Measures on Human Rights Around the World. Bangkok: GAATW,. 2007. p. 129.

${ }^{145}$ ASBRAD. Metodologia de recepção e atendimento a mulheres e "trans" possíveis vítimas de tráfico de pessoas no universo de deportadas e inadmitidas recebidas pelo Posto de Atendimento Humanizado aos(às) Migrantes. Guarulhos, 2009. Disponível em: <http://www.asbrad.com.br/conteúdo/Metodologia.pdf $>$. Acesso em: 20 jul. 2012. 
pessoas ocorre apenas na hipótese da consumação inegável e absoluta do engano, do logro, como se fosse simples comprovar esse tipo de situação, não houvesse nuances na sua caracterização e fosse corriqueira a sua ocorrência nesse estado puro e radical. Em todos os casos existe uma redução conceitual do sentido contido no Protocolo.

Tradicionalmente o tráfico de pessoas está relacionado com a consequente exploração da mão de obra em condições de escravidão. Por sua vez, o trabalho prestado em condições de servidão sempre esteve presente em "todas las naciones bárbaras o civilizadas, grandes o pequeñas, poderosas o débiles, pacificas o guerreras, bajo las más diversas formas de gobierno, profesando las religiones más contrarias, y sin distinción de climas y edades". ${ }^{146}$ Dessa maneira, observamos uma relação intrínseca entre o tráfico de pessoas e o trabalho análogo ao de escravo, onde quer que essas figuras nefastas de exploração da pessoa humana ocorram e sob qualquer que seja a sua justificativa e modalidade de ocorrência.

Ademais, segundo o Escritório das Nações Unidas sobre Drogas e Crime (UNODC), $\mathrm{o}$ tráfico de pessoas representa uma grave violação de direitos humanos fundamentais, ${ }^{147} \mathrm{e} o$ Brasil, ao ratificar Protocolo de Palermo em 2003, reafirma seu compromisso no combate a essas formas modernas de escravidão e vulneração dos direitos humanos. Vale ressaltar que o Protocolo de Palermo, por ter nítida natureza de Tratado Internacional de Direitos Humanos recepcionado pelo ordenamento jurídico brasileiro, possui natureza de norma, no mínimo, supralegal.

No que se relaciona com o enfrentamento ao trabalho análogo ao de escravo, é importante compreender a dimensão do tráfico de pessoas que tenha por finalidade esse específico tipo de exploração econômica, de acordo com a definição do Protocolo: o trabalho ou serviços forçados, escravatura ou práticas similares à escravatura ou a servidão. Da mesma forma, é importante ressaltar que, no campo das ações típicas relacionadas ao tráfico de pessoas, o alojamento e o acolhimento de trabalhadores, com a finalidade de submetê-los a condições análogas às de escravo, são as duas formas típicas comuns a todos os casos de submissão de trabalhadores ao trabalho escravo em território brasileiro.

\footnotetext{
${ }^{146}$ SACO, José Antonio. Historia de la esclavitud. Buenos Aires: Editorial Andina S.R.L., 1965. p. 7.

${ }^{147}$ Disponível em: http://www.unodc.org/lpo-brazil/pt/trafico-de-pessoas/ungift.html. Último acesso em: 30 abr. 2013.
} 
O Brasil, ao aprovar a Política Nacional de Enfrentamento ao Tráfico de Pessoas, ${ }^{148}$ trouxe algumas definições fundamentais. Determina que a expressão "escravatura ou práticas similares à escravatura" deve ser entendida como a conduta definida no art. 149 do Código Penal. Ao tratar do aliciamento de mão de obra afirma em seu artigo $2^{\circ}$. § $4^{\circ}$. que "a intermediação, promoção ou facilitação do recrutamento, do transporte, da transferência, do alojamento ou do acolhimento de pessoas para fins de exploração também configura tráfico de pessoas".

Ainda a Política dá a condição de transnacionalidade ao indicar que é indiferente se tratar de tráfico interno ou internacional, trabalhadores brasileiros ou migrantes. ${ }^{149} \mathrm{E}$ além disso reforça a irrelevância quanto ao consentimento da vítima para a sua caracterização. ${ }^{150}$

É importante ressaltar o entendimento da OIT de que "o tráfico de pessoas possui uma estreita relação com o trabalho forçado. Com efeito, a principal finalidade do tráfíco de pessoas é fornecer mão de obra para o trabalho forçado, seja para a exploração sexual comercial, seja para a exploração econômica, ou para ambas as finalidades."151 São dimensões diferentes do mesmo fenômeno. Enquanto “[n]o tráfico de pessoas observa-se a questão sob o ponto de vista mercadológico, em que existe uma transação baseada na exploração do ser humano, no trabalho escravo, o tema é analisado sob uma perspectiva do modelo produtivo, centrado na primazia do trabalho, no qual ocorre um desvio de finalidade redundando em uma mercantilização da força do trabalho humano.",152

A mobilidade geográfica, elemento que também pode caracterizar o tráfico de pessoas, é responsável por um adicional de vulnerabilidade, além do econômico, responsável pelo círculo vicioso que perpetua as situações de trabalho escravo. Em se tratando de migrantes, os beneficiários desse tipo de trabalho podem aproveitar da situação

\footnotetext{
${ }^{148}$ Decreto $^{\mathrm{o}} 5.948$, de 26 de Outubro de 2006, recentemente reformulado pelo Decreto $\mathrm{n}^{\mathrm{o}} 7.901$, de 4 de Fevereiro de 2013.

${ }^{149}$ Decreto $^{\circ} 5.948$, de 26 de Outubro de 2006.

Art. $2^{\circ} . \S 5^{\circ} \mathrm{O}$ tráfico interno de pessoas é aquele realizado dentro de um mesmo Estado-membro da Federação, ou de um Estado-membro para outro, dentro do território nacional.

$\S 6^{\circ} \mathrm{O}$ tráfico internacional de pessoas é aquele realizado entre Estados distintos.

${ }_{150} \quad$ Decreto $^{\circ}$ 5.948, de 26 de Outubro de 2006.

Art. $2^{\circ} \S 7 \mathrm{o} O$ consentimento dado pela vítima é irrelevante para a configuração do tráfico de pessoas.

${ }^{151}$ FAUZINA, Ana Luiza; VASCONCELOS, Márcia; FARIA, Thaís Dumêt. Manual de capacitação sobre tráfico de pessoas. Brasília: Organização Internacional do Trabalho, 2009. p. 10-11.

${ }^{152}$ BIGNAMI, Renato. Trabalho escravo contemporâneo: o sweating system no contexto brasileiro como expressão do trabalho escravo urbano. In: VELLOSO, Gabriel e FAVA, Marcos Neves (Coords.). Trabalho escravo contemporâneo - o desafio de superar a negação. 2. ed. São Paulo: LTr, 2011.
} 
migratória para ameaçá-los deportar do país, garantindo a assimetria no mercado de trabalho entre aqueles que empregam mão de obra escrava e aqueles que seguem as normas legais.

A finalidade maior do tráfico de pessoas para fins econômicos é o lucro, obtido com a exploração do trabalho análogo ao de escravo, que é potencializado, após a chegada ao destino, com o alojamento e o acolhimento.

Contudo, a mobilidade não é o fator principal que caracteriza o tráfico de pessoas, pois se ocorreu o rebaixamento da pessoa para fins de comercialização econômica, ocorreu trabalho escravo e, logo, tráfico de pessoas. Busca-se, dessa maneira, imprimir um sentido mais relacionado com a proibição da mercantilização do trabalho e baseado no respeito aos direitos humanos.

O Tráfico de Pessoas não é apenas um crime; é também uma teia de fatores sociais, com ligações entre trabalho e migração. O foco exclusivo no tráfico sem uma análise social pode levar a crer que é um problema que pode ser resolvido apenas com uma medida legal para o traficante ou aliciador, e assistência para aqueles que são identificados como vítimas.

Qualquer ação que vise proteger vítimas ou possíveis vítimas tem que considerar contextos mais amplos, como o familiar, sem se desvincular de fatores econômicos decorrentes da globalização. As mudanças do mercado econômico global alteram estruturas que regem a liberdade de trabalho e de movimento das pessoas. Para Vidyamali Samarasinghe, a globalização "adds new dimensions to the pattern and structure of trafficking." ${ }^{153}$ E nestas novas variáveis, inclui-se a marginalização social e econômica e a desigualdade de gênero.

${ }^{153}$ SAMARASINGHE, Vidyamali, Confronting Globalization in Anti-Trafficking Strategies in Asia. In: Brown Journal of World Affairs, n. 10, 2003. p. 91-93. 


\section{CONSIDERAÇÕES FINAIS}

A intensificação dos fluxos migratórios contemporâneos ocorre, por um lado, por conta da possibilidade de ascensão social atrelada à ideia de globalização, e, por outro, da mão de obra barata, desprotegida de direitos de cidadania.

Entre as posições subalternas que essa migração permite, inclui-se a disposição em trabalhar sem documentos, sem garantias trabalhistas e por salários baixos, com a perspectiva ilusória de integrar o mundo capitalista, ou mesmo por ser a única alternativa que lhes restam.

Porém, a condição subalterna da experiência vivida por quem migra nessas condições remete a formas coloniais de poder e saber, presentes ainda nos modos de viver e apreender o mundo.

Nesse contexto, visualizamos a história de vida de mulheres que não só deixam seu país em um cenário de desemprego, pobreza e poucas oportunidades, aspectos intimamente ligados à sobrevivência, mas que também deixam filhas e filhos, familiares e amigos, em busca de outra vida, em outro território, com a esperança e a possibilidade de alcançar uma melhor qualidade de vida para si e para os seus.

A representação da mulher nas migrações não parte de um paradigma homogêneo da imagem feminina. Mesmo que definidas pelo sexo, a categoria biológica é transpassada para dar lugar a sua existência social, compreendendo mulheres de situações familiares diversas, de diferentes idades, que pertencem a diferentes classes sociais, países e comunidades.

Muitas são solteiras, outras, casadas; algumas decidem sozinhas, e existem aquelas que participam de um projeto familiar. Há as que contam com o apoio financeiro e emocional de familiares, outras migram para iniciar sua família, e ainda aquelas que se deslocam para fugir de um passado de violência e opressão.

Agregam à sua condição feminina a condição de mães, esposas, filhas, irmãs, primas e amigas que iniciam a etapa de um projeto familiar, criando os laços necessários no país de destino.

Diversos fatores se inter-relacionam para explicar a migração intrarregional de 
mulheres para a cidade de São Paulo, para além dos fatores do mercado de trabalho e disparidade de renda.

As redes sociais, a presença de uma experiência familiar e histórica de migração, os processos simbólicos de negociação e construção de identidades, são mesclados por questões de gênero, raça e classe social. E nesse quadro o tipo e as condições de entrada no mercado de trabalho no destino têm papel significativo.

A saída de seu país de origem acarreta, para muitas, o afastamento físico da família, que se reconfigura na nova situação, mantendo-se os elos afetivos por meio de telefonemas e de remessas de dinheiro, atualmente fundamentais à economia não só das famílias, mas também do seu país natal.

E estas mudanças também precisam estar na agenda daqueles que pensam sobre a migração, com o objetivo de proporcionar uma migração segura. E isso pressupõe o reconhecimento da migração como uma característica da economia global e também um direito humano.

$\mathrm{Na}$ atual conjuntura, os acordos entre os países do MERCOSUL e associados é um caminho positivo para ampliar as possibilidades de mobilidade humana, e uma possível ampliação para o nível da UNASUL aponta para uma tendência humanista em que o valor da vida não é emparelhado ao seu valor produtivo.

Cabe também uma discussão importante sobre a questão do trabalho digno, da remuneração justa, de um ambiente de trabalho seguro e da proteção social para si e familiares. Bem como a problematização do funcionamento da cadeia produtiva e das estratégias de exploração da mão de obra barata.

Saber sobre seus direitos no país de destino pode ser um instrumento para que as pessoas façam melhores escolhas. E, no país de origem, é premente a construção de políticas públicas de caráter social com efeitos na acolhida e na inserção de migrantes em nossa sociedade. Com as informações necessárias e a proteção adequada, a migração pode ser uma opção valiosa e lucrativa tanto para as pessoas como também para os países de destino.

Ações nesse sentido devem se pautar também por uma perspectiva de gênero, com problematizações trazidas por discussões feministas, e que tratem de forma igualitária 
mulheres e homens.

O protagonismo crescente das mulheres nas migrações nos mostra a existência de uma maior independência e autonomia. As histórias de vida compreendidas neste trabalho mostram que a migração internacional é uma alternativa diante das situações de pobreza e conflito no país de origem, nos quais elas não encontram mais possibilidades de negociação ou apoio dos serviços sociais ou de sua comunidade. Percebemos que para além do título "vítima" ou "heroína", as entrevistadas se submetem a situações de risco e incertezas pela manutenção de sua família.

Almejamos que as vozes não integradas, em um passado e no presente, aos discursos predominantes, no nosso caso as mulheres migrantes de países em situação econômica desfavorável, sejam incluídas em um discurso futuro. 


\section{REFERÊNCIAS}

ABRAMO, Laís. A situação da mulher latino-americana - o mercado de trabalho no contexto de reestruturação. In: DELGADO, Didice G., CAPPELLIN, Paola e SOARES, Vera (Orgs.). Mulher e trabalho: experiências de ação afirmativa. São Paulo: Boitempo Editorial, 2000, p.76-93.

ARENDT, Hannah. Origens do totalitarismo. São Paulo: Companhia das Letras, 2004.

ARIZA, Marina. Migración, familia y transnacionalidad en el contexto de la globalización: algunos puntos de reflexión. In: Revista Mexicana de Sociología, vol. 64, no 4, 2002. p. 5384.

ARTEAGA, Ana María. Mujeres en la migración andina hacia países de la Union Europea y especialmente a España: Contexto, Políticas y Gestión Migratoria. Disponível em: $<$ http://www.oxfamintermon.org/sites/default/files/documentos/files/101103_mujeres ndinas.pdf $>$. Acesso em: 22 out. 2013

ASBRAD. Metodologia de recepção e atendimento a mulheres e "trans" possiviveis vitimas de tráfico de pessoas no universo de deportadas e inadmitidas recebidas pelo Posto de Atendimento Humanizado aos(às) Migrantes. Guarulhos, 2009. Disponível em: $<$ http://www.asbrad.com.br/conteúdo/Metodologia.pdf $>$. Acesso em: 20 jul. 2012.

BAENINGER, Rosana e PATARRA, N. L. Migrações internacionais, globalização e blocos de integração econômica: Brasil no Mercosul. In: CANALES, Alejandro I. (Org.).

Panorama actual de las migraciones en America Latina. Guadalajara: Universidad de Guadalajara, 2006, v.1, p. 118.

BAENINGER, Rosana e SOUCHAUD, Sylvain. Vínculos entre a migração internacional e a migração interna: o caso dos bolivianos no Brasil. In: OFICINA NACIONAL SOBRE MIGRACIÓN INTERNA Y DESARROLLO EN BRASIL: DIAGNÓSTICO, PERSPECTIVAS Y POLITÍCAS, Brasília, 2007.

BERNHARD, Judith K.; LANDOLT, Patricia e GOLDRING, Luin. Transnational, MultiLocal Motherhood: Experiences of Separation and Reunification among Latin American Families in Canada. In: Early Childhood Education Publications and Research. Paper 6, 2005.

BERTAUX-WIAME, Isabelle. The Life History Approach to the Study of Internal Migration. In Oral History vol. 7, $\mathrm{n}^{\mathrm{o}}$ 1, 1979. p. 26-32 
BIBLIOTECA VIRTUAL DE DIREITOS HUMANOS. Declaração e Programa de Ação de Viena - 1993. Disponível em: $<$ http://www.direitoshumanos.usp.br/index.php/SistemaGlobal.-Declarações-e-Tratados-Internacionais-de-Proteção/declaracao-e-programa-de-acaode-viena.html>. Acesso em: 20 jul. 2012.

BIGNAMI, Renato. Trabalho escravo contemporâneo: o sweating system no contexto brasileiro como expressão do trabalho escravo urbano. In: VELLOSO, Gabriel e FAVA, Marcos Neves (Coords.). Trabalho escravo contemporâneo - o desafio de superar a negação. 2. ed. São Paulo: LTr, 2011.

BIGNAMI, Renato; NOGUEIRA, Christiane; NOVAES, Marina; PLASSAT, Xavier. O tráfico de pessoas e trabalho escravo: além da interposição de conceitos. In: BIGNAMI, Renato; NOGUEIRA, Christiane; NOVAES, Marina (Orgs.). Tráfico de Pessoas, reflexões para a compreensão do trabalho escravo contemporâneo. São Paulo: Ed. Paulinas, 2014.

BJEREN, G. Gender and reproduction. In: HAMMAR, T.; BROCHMANN, G.; TAMAS, K. e FAIST, T. (Orgs.). International migration, immobility and development: multidisciplinary perspectives. Oxford, 1997. p. 219-246.

BLOCH, Marc. Apologia da História. Rio de Janeiro: Jorge Zahar, 2001.

BOSI, Eclea. O Tempo Vivo da Memória: ensaios de psicologia social. São Paulo: Ateliê Editorial, 2003.

BRASIL. Lei ${ }^{0}$ 6.815, de 19 de agosto de 1980. Diário Oficial da União. Disponível em: $<$ http://www.planalto.gov.br/ccivil_03/leis/16815.htm>. Acesso em 26 set. 2012.

BRASIL. Decreto n ${ }^{\circ}$ 5.948, de 26 de Outubro de 2006. Diário Oficial da União. Disponível em: < http://www.planalto.gov.br/ccivil_03/_Ato2004-2006/2006/Decreto/D5948.htm> . Acesso em: 28 mar. 2014.

BRASIL. Decreto $\mathrm{n}^{\circ} 7.901$, de 4 de Fevereiro de 2013. Diário Oficial da União. Disponível em: < http://www.planalto.gov.br/ccivil_03/_Ato2011-2014/2013/Decreto/D7901.htm>. Acesso em: 28 mar. 2014.

BRYCESON, D. e VUORELA, U. The Transnational family. New European frontiers and global networks. Oxford: Berg, 2002. Apud: ACP OBSERVATORY ON MIGRATION. Transnational families and the social and gender impact of mobility in ACP countries. 
Disponível em: $<$ http://www.acpmigration-obs.org/sites/default/files/ENBN06Families.pdf>. Acesso em: 07 jan. 2014.

CADERNOS PAGU. Trânsitos. Edição 31. Campinas: Unicamp/NEG, 2008.

CASTEL, Robert. As metamorfoses da questão social: uma crônica do salário. Petrópolis: Ed. Vozes, 1998.

CASTELLANOS, Patricia Cortés. Mujeres migrantes de América Latina y el Caribe: derechos humanos, mitos y duras realidades. In: Programa Regional de Población y Desarrollo Centro Latinoamericano y Caribeño de Demografía (CELADE) - División de Población / Fondo de Población de las Naciones Unidas. Santiago do Chile, 2005. p. 23.

CERRUTTI, Marcela. Gender and Intra-regional regional migration in South America. In: United Nations Development Programm, Human Development Research Papers. dezembro de 2009.

COMISSÃO NACIONAL DE POPULAÇÃO E DESENVOLVIMENTO. ORGANIZAÇÃO INTERNACIONAL PARA AS E MIGRAÇÕES E MINISTÉRIO DO TRABALHO E EMPREGO. Perfil Migratório do Brasil 2009. OIM Publications, 2010. p.16.

CSEM. Conceitos básicos de migração segundo a Organização Internacional para as Migrações - OIM. Disponível em:

$<$ http://www.csem.org.br/pdfs/conceitos_basicos_de_migracao_segundo_a_oim.pdf $>$. Acesso em: 29 ago. 2013.

ECLAC. 2006 International Migration. Latin America and the Caribbean Demographic Observatory. Santiago do Chile: United Nations, ECLAC.

EHRENREICH, Barbara e HOCHSCHILD, Arlie Russel. Global women: nannies, maids and sex workers in the new economy. Nova Iorque: Henry Holt and Company, 2002.

ENGLE, Lauren B. The World in Motion: Short Essay on Migration and Gender. Genebra: IOM, 2004. p. 5.

EVANGELISTA, Marcela Boni. A transcriação em história oral e a insuficiência da entrevista. In: Oralidades. Revista de História Oral. n.7. Jan-Jun/2010. 
FAUZINA, Ana Luiza; VASCONCELOS, Márcia; FARIA, Thaís Dumêt. Manual de capacitação sobre tráfico de pessoas. Brasília: Organização Internacional do Trabalho, 2009. p. 10-11.

FREITAS, Sônia Maria de. História Oral. Possibilidades e procedimentos. São Paulo: Humanitas, 2006.

GAATW (Ed.). Beyond Borders: Exploring Links between Trafficking and Labour. Working Paper Series. Bangkok: GAATW, 2010. p. 8.

GAATW (Ed.). Collateral Damage: The Impact of Anti-Trafficking Measures on Human Rights Around the World. Bangkok: GAATW, 2007. p. 129.

GLUCK, Sherna. What's so Special about Women? Women's Oral History. In: Frontiers: A Journal of Women Studies, edição especial, vol II, 1977. p. 3-14.

HALL, Stuart. Quem precisa da identidade? In: SILVA, Tomaz Tadeu da e WOODWARD, Kathryn (Orgs.). Identidade e Diferença: a perspectiva dos estudos culturais. Rio de Janeiro: Vozes, 2000.

HAZEU, Marcel. Migração Internacional de mulheres na periferia de Belém: identidades, famílias transnacionais e redes migratórias em uma cidade na Amazônia. Dissertação de mestrado - Núcleo de Altos Estudos Amazônicos-Universidade Federal do Pará, Belém, 2011.

HERRERA, Gioconda. Mujeres ecuatorianas en el trabajo doméstico en España. In: NOVICK, Susana (Org.). Las migraciones en América Latina. Buenos Aires: Consejo Latinoamericano de Ciencias Sociales - CLACSO, 2008.

HIRATA, Helena. Emprego, responsabilidades familiares e obstáculos socioculturais à igualdade de gênero na Economia. In: CONFERÊNCIA REGIONAL SOBRE A MULHER DA AMÉRICA LATINA E DO CARIBE, 11, Painel. Brasília, 14 jul. 2010.

HOBSBAWM, Eric. O Presente como História. In: Sobre História. São Paulo: Companhia das Letras, 2005. p. 245.

HOBSBAWN, Eric; RANGER, Terence (Orgs.). A Invenção das tradições. Rio de Janeiro: Paz e Terra, 1997. 
HOLANDA, Fabíola e MEIHY, José Carlos Sebe Bom. História Oral: como fazer como pensar. São Paulo: Contexto, 2007.

IANNI, Octavio. A era do Globalismo. Rio de Janeiro: Civilização Brasileira, 1996.

IANNI, Octavio. Teorias da Globalização. Rio de Janeiro: Civilização Brasileira, 1997.

ILLES, Paulo; TIMÓTEO, Gabriela L. S.; FIORUCCI, Eliana da S. Tráfico de pessoas para fins de exploração do trabalho na cidade de São Paulo. In: Cadernos Pagu, Campinas: Unicamp/NEG. n. 31, 2008, p. 119-217.

INTERNATIONAL LABOUR OFFICE. Forced labour and human trafficking. Casebook of court decisions. A training manual for judges, prosecutors and legal practitioners. Genebra: International Labour Organization, 2009. p. 9.

INTERNATIONAL ORGANIZATION FOR MIGRATION. Gender and Migration News. n. 34, abril 2010. Disponível em:

$<$ http://www.iom.int/jahia/webdav/site/myjahiasite/shared/shared/mainsite/published_docs/p eriodicals_and_newsletters/gender_bulletin_apr10.pdf >. Acesso em: 20 jan. 2014

INTERNATIONAL ORGANIZATION FOR MIGRATION. International Migration Law N²5 - Glossary on Migration. Disponível em:

$<$ http://publications.iom.int/bookstore/free/Glossary\%202nd\%20ed\%20web.pdf $>$. Acesso em 09 dez. 2013.

JOUTARD, Philippe. História oral: balanço da metodologia e da produção nos últimos 25 anos. In: FERREIRA, Mariete de Moraes e AMADO, Janaína (Orgs.). Uso e abusos da História oral. 7 ed. Rio de Janeiro: Fundação Getúlio Vargas, 2005. p. 43-62.

KEMPADOO, Kamala. Mudando o debate sobre o tráfico de mulheres. In: Cadernos Pagu, Campinas: Unicamp/NEG, n. 25, jul-dez. 2005, p. 55-78.

LESSER, Jeffrey. A negociação da identidade nacional: imigrantes, minorias e a luta pela etnicidade no Brasil. Trad. Patrícia de Queiroz C. Zimbres. São Paulo: Editora da UNESP, 2001 .

LEVI, Giovanni. A herança imaterial: trajetória de um exorcista no Piemonte do século XVII. Rio de Janeiro: Civilização Brasileira, 2000. p. 272. 
MARTÍNEZ, Jorge e VONO, Daniela. Geografía migratoria intraregional de América Latina y el Caribe al comienzo del siglo XX. In: Revista de Geografia Norte Grande, Santiago, Chile, n. 34, dezembro de 2005. p.45.

MARTÍNEZ PIZARRO, Jorge. América Latina y el Caribe: migración internacional, derechos humanos y desarrollo. Santiago do Chile: División de Población / Fondo de Población de las Naciones Unidas, 2005.

MARTINS, José de Souza. O problema das migrações no limiar do terceiro milênio. In: Vários autores. O Fenômeno Migratório no Limiar do Terceiro Milênio: desafios pastorais. Petrópolis, RJ: Vozes, 1998. p.22

MEIHY, José Carlos Sebe Bom. Manual de história oral. São Paulo: Edições Loyola, 2005. p. 24

MEIHY, José Carlos Sebe Bom. Reintroduzindo História Oral no Brasil. São Paulo: Xamã, 1996.

MEIHY, José Carlos Sebe Bom. A colônia Brasilianista: história oral de vida acadêmica. São Paulo: Nova Stella, 1990.

MINISTÉRIO DA JUSTIÇA. Número de estrangeiros regulares no Brasil aumenta $50 \%$ em seis meses. Disponível em:

$<$ http://portal.mj.gov.br/data/Pages/MJA5F550A5ITEMIDF7B2EE1D60D4405F80C9C91D 4EA12FC3PTBRNN.htm>. Acesso em 21 jun. 2012.

MINISTÉRIO DA JUSTIÇA. Portaria nº 2.162 de 29 de maio de 2013. Diário Oficial da União. Disponível em: <http://migre.me/is0C7>. Acesso em 22 mar. 2014.

MINISTÉRIOS DE ESTADO DAS RELAÇÕES EXTERIORES E DA JUSTIÇA. Portaria Interministerial de 28 de agosto de 2006. In: Diário Oficial da União, Seção I, $N^{\circ} 166$, terça-feira, 29 de agosto de 2006, p. 66-67.

NEDERSTIGT, Frans Willen Pieter Marie. Situações de vulnerabilidade para ser traficada. In: BRASIL. Secretaria Nacional de Justiça do Ministério da Justiça. Organização Internacional do Trabalho (OIT). Escritório das Nações Unidas contra Drogas e Crime (UNODC). I Prêmio Libertas: enfrentamento ao tráfico de pessoas. Brasília: 2010. p. 289318. 
NOVAES, Marina M. Negotiating Rights at the Workplace. In: GAATW

INTERNATIONAL MEMBERS CONGRESS AND CONFERENCE (IMCC). Bangkok, Tailândia, julho de 2010.

NOVAES, Marina M. A experiência do Centro de Apoio ao Migrante no atendimento e o contexto da feminização das migrações. In: SIQUEIRA, Priscila e QUINTEIRO, Maria (Orgs.) Tráfico de Pessoas: quanto vale o ser humano na balança comercial do lucro? São Paulo: Idéias \& Letras, 2013. p. 75-104.

OIT. Convenção(29) sobre o trabalho forçado ou obrigatório. Disponível em: $<\mathrm{http}$ //www.oit.org.br/sites/all/forced_labour/oit/convencoes/conv_29.pdf $>$. Acesso em: 26 abr. 2014.

OSO, Laura. Migración, género y hogares transnacionales. In: CONGRESO DE LA INMIGRACIÓN EN ESPAÑA, 5, Valencia, 2007.

OSO Casas, L.; GARSON, J-P. The feminisation of international migration: Migrant Women and the Labour Market: Diversity and Challenges. In: OECD AND EUROPEAN COMMISSION SEMINAR, Bruxelas, 2005.

OSO CASAS, Laura. Movilidad laboral de las mujeres latinoamericanas en España y empresariado étnico. In: Familias, niños, niñas y jóvenes migrantes: rompiendo estereotipos. Madrid: Iepala editorial, 2010. pp. 33-46.

PARELLA, Sonia e CAVALCANTI, Leonardo. Dinámicas Familiares Transnacionales y Migración Femenina: El Caso De Las Migrantes Bolivianas En España. 2008. Disponível em: $<\mathrm{http}: / /$ webs.uvigo.es/xenero/profesorado/sonia_parella/migracion.pdf $>$. Acesso em: 05 jan.2014.

PARK, Robert. Human Migrations and the Marginal Man. In: The American Journal of Sociology, vol 33, $\mathrm{n}^{\circ}$ 6, 1928.

PARREÑAS, Rhacel Salazar. Servants of Globalization: Women, Migration, and Domestic Work. Londres: Stanford University Press, 2001.

PATARRA, Neide Lopes. Migrações Internacionais: teorias, políticas e movimentos sociais. In: Estudos Avançados. São Paulo, v. 20, n. 57, agosto 2006. Disponível em: http://migre.me/is09d. Acesso em: 22 mar. 2014. 
PATARRA, Neide Lopes. Migrações internacionais de e para o Brasil contemporâneo: volumes, fluxos, significados e políticas. In: São Paulo em Perspectiva, v. 19, n. 3, jul/set. 2005. p. 23-33.

PEDONE, Claudia. "Varones aventureros" vs. "Madres que abandonan": reconstrucción de las relaciones familiares a partir de la migración ecuatoriana. In: REMHU. Revista Interdisciplinar da Mobilidade Humana, $n^{\circ}$ 30, 2008. p. 45-64.

PERROT, Michelle. As mulheres ou os silêncios da história. Bauru: EDUSC, 2005.

PIOVESAN, Flavia. Direitos sociais, econômicos e culturais e direitos civis e políticos. In: Sur, Rev. int. direitos humanos. São Paulo, vol.1, n.1, 2004.

PIPER, Nicola. Gender and Migration. Paper preparado para o Policy and Research Programme of the Global Commission on International Migration. 2005. Disponível em: <www.gcim.org>. Acesso em: 28 mar. 2014.

PISCITELLI, Adriana. Sujeição ou Subversão? Migrantes Brasileiras na Indústria do Sexo na Espanha. In: Revista História e Perspectivas, $n^{\circ}$ 35, Uberlândia-MG: Universidade Federal de Uberlândia, 2006. p.13-55.

PNUD. Relatório de Desenvolvimento Humano 2009. Ultrapassar Barreiras: Mobilidade e desenvolvimento humanos. Nova Iorque: 2009.

POLLAK, Michael. Memória, Esquecimento, Silêncio. In: Estudos Históricos. Rio de Janeiro, vol.2, n. 3, 1989. p. 3-15.

PÓVOA NETO, Helion e FERREIRA, Ademir P. (Orgs.). Cruzando Fronteiras disciplinares. Um panorama dos estudos migratórios. Rio de Janeiro: Revan, 2005. p. 11.

PRADO, Maria Ligia C. Em busca da participação política das mulheres nas lutas pela independência da América Latina. In: Revista Brasileira de História. São Paulo, n. 23/24, 1992. p. 77-90.

PYL, Bianca e HASHIZUME, Maurício. Roupas da Zara são fabricadas com mão de obra escrava. Repórter Brasil, São Paulo, 16 ago. 2011. Disponível em: $<$ http://reporterbrasil.org.br/2011/08/roupas-da-zara-sao-fabricadas-com-mao-de-obraescrava/>. Acesso em: 18 out. 2013. 
PYL, Bianca. Trabalho escravo é flagrado na cadeia da Pernambucanas. Repórter Brasil, São Paulo, 02 abr. 2011. Disponível em: <http://reporterbrasil.org.br/2011/04/trabalhoescravo-e-flagrado-na-cadeia-da-pernambucanas/>. Acesso em : 18 out. 2013.

RAGO, Margareth. Descobrindo historicamente o gênero. In: Cadernos Pagu. Campinas: Unicamp/NEG, n. 11, 1998. p.89-98.

RIBAS MATEOS, Natalia. Una Invitación a la sociología de las migraciones. Barcelona: Bellaterra, 2004. p. 78-80.

RODRIGUEZ, Gabriela P. Derechos Humanos de los Migrantes. Informe apresentado à Comissão de Direitos Humanos, $56^{\circ}$ período de seções, Nova York, Nações Unidas. 2000. p.3.

ROSAS, Carolina. ¿Migras tú, migro yo o migramos juntos? Los condicionantes de género en las decisiones migratorias de parejas peruanas destinadas en Buenos Aires. In: JORNADAS ARGENTINAS DE ESTUDIOS DE POBLACION (AEPA), 9, Huerta Grande, Córdoba, 31 de Outubro a 2 de Novembro de 2007.

SACO, José Antonio. Historia de la esclavitud. Buenos Aires: Editorial Andina S.R.L., 1965. p. 7.

SAKAMOTO, Leonardo (Coord.). Trabalho escravo no Brasil do século XXI. Brasília: Organização Internacional do Trabalho, 2007. p. XIII.

SALA, Gabriela Adriana e CARVALHO, José Alberto Magno de. A presença de imigrantes de países do Cone Sul no Brasil: medidas e reflexões. In: Rev. bras. estud. popul. [online]. 2008, vol.25, n.2, p. 287-304. ISSN 0102-3098. Disponível em: <http://dx.doi.org/10.1590/S0102-30982008000200006>. Acesso em: 14 mai. 2012.

SAMARASINGHE, Vidyamali. Confronting Globalization in Anti-Trafficking Strategies in Asia. In: Brown Journal of World Affairs, n. 10, 2003. p. 91-93.

SÁNCHEZ BARRICARTE, Jesús Javier. Socioeconomía de las migraciones en un mundo globalizado. Madrid: Biblioteca Nueva, 2010. p. 31-32.

SANTOS, Boaventura de Sousa. Por uma concepção multicultural de Direitos Humanos. In: Lua Nova, revista de Cultura Política. Centro de Estudos de Cultura Contemporânea. São Paulo, 1997. 
SANTOS, Boaventura de Sousa. Renovar a teoria crítica e reinventar a emancipação social. São Paulo: Boitempo, 2007. p.51.

SANTOS, Boaventura de Sousa; GOMES, Conceição; DUARTE, Madalena; BAGANHA, Maria Ioannis. Tráfico de Mulheres em Portugal para Fins de Exploração Sexual, Projecto CAIM - Cooperação. Acção. Investigação. Mundivisão. Coimbra: Centro de Estudos Sociais (CES), 2007.

SARLO, Beatriz. Mulheres, História e Ideologia. In: SARLO, Beatriz. Paisagens Imaginárias. Edusp. São Paulo, 2005.

SASSEN, Saskia. Contrageografias de la globalización. Género y ciudadanía en los circuitos transfronterizos. Madrid: Traficantes de Sueños, 2003.

SASSEN, Saskia. The Global City. New York, London, Tokyo. Princeton, New Jersey: Princeton University Press, 1991.

SAYAD, Abdelmalek. O retorno: elemento constitutivo da condição do imigrante. In: Travessia - Revista do Migrante. São Paulo: Centro de Estudos Migratórios, n.1, especial, janeiro 2000. p. 08.

SAYAD, Abdelmalek. A imigração ou os paradoxos da alteridade. São Paulo, Edusp, 1998.

SCANDOLA, Estela Márcia. Sujeitas de direitos, prostituição, tráfico de pessoas e migração: uma rede de inquietações. In: Conversação, ano III, n. 5, 2008. p 36-37.

SCOTT, Joan Wallach. Gênero: uma categoria útil de análise histórica. In: Educação \& Realidade. Porto Alegre, vol. 20, nº 2, jul./dez.1995.

SCOTT, Joan Wallach. A mulher trabalhadora. In: DUBY, Georges; PERROT, Michelle (Dir.). A histó ria das mulheres: o século XIX (vol.4). Porto: Edições Afrontamento e São Paulo: Ebradil, 1994. p. 443- 475.

SIQUEIRA, Priscila. Tráfico de pessoas e suas implicações políticas. In: Conversação, ano III, n.5, 2008, p 4-6. 
SILVA, Sidney Antonio da. Bolivianos em São Paulo: entre o sonho e a realidade. In: Estud. av. [online]. 2006, vol.20, n.57, pp. 157-170. Disponível em:

$<$ http://dx.doi.org/10.1590/S0103-40142006000200012>. Acesso em: 09 set. 2012.

SILVA, Sidney Antonio da. Virgem/Mãe/Terra. Festas e tradições bolivianas na metrópole. São Paulo: Hucitec/Fapesp, 2003.

THOMPSON, Paul. A voz do passado: história oral. 3. ed. Rio de Janeiro: Paz e Terra, 1992.

SOUZA, Claudia Moraes. Deslocamentos Contemporâneos e Tráfico de Pessoas em Cidades Globais: Dilemas, Ações e Solidariedade. In Tráfico de pessoas : uma abordagem para os direitos humanos / Secretaria Nacional de Justiça, Departamento de Justiça , Classifição, Títulos e Qualificação; organização de Fernanda Alves dos Anjos ... [et al.]. 1.ed. Brasília : Ministério da Justiça, 2013.

THOMSON, Alistair. Histórias (co) movedoras: História oral e estudos de migração. In: Rev. Bras. Hist., vol.22, n.44, 2002. p.341-364.

UCHOA, Pablo. Supremo americano limita lei anti-imigração do Arizona. BBC Brasil. Disponível em:

<www.bbc.co.uk/portuguese/noticias/2012/06/120625_arizonalei_pu.shtml >. Acesso em: 21 mar. 2014.

UNFPA. State of World Population 2006: A Passage to Hope: Women and International Migration. Disponível em: <http://www.unfpa.org/swp/2006/> . Acesso em: 13 set. 2012.

UNFPA. State of World Population 2011: People and Possibilities in a World of 7

Billion. Disponível em: <http://www.unfpa.org/swp/2011>. Acesso em: 09 mai. 2012.

UN.GIFT. Iniciativa Global da ONU contra o Tráfico de Pessoas. Disponível em: $<$ http://www.unodc.org/lpo-brazil/pt/trafico-de-pessoas/ungift.html $>$. Acesso em: 26 abr. 2014.

UNITED NATIONS. International migrant stock: the 2008 revision. Disponível em: $<\mathrm{http}$ ://esa.un.org/migration/index.asp?panel=1>. Acesso em: 13 set. 2012.

VENTURA, Deisy e ILLES, Paulo. Estatuto do estrangeiro ou lei de imigração? Le Monde Diplomatique Brasil. Agosto de 2010, p. 14-15. 
VIDAL, Dominique. Convivência, alteridade e identificações. Brasileiros e Bolivianos nos bairros centrais de São Paulo. In: BAENINGER, Rosana (Org). Imigração Boliviana no Brasil. Campinas: Núcleo de Estudos de Populações/ Unicamp, 2012. p. 98.

ZLOTNIK, Hania. The global dimensions of female migration Migration Information Source.. In: Migration Policy Institute, Washington, D.C., 2003. Disponível em:

<www.migrationinformation.org/Feature/print.cfm?ID=109>. Acesso em: 23 mai. 2012.

ZOCCHIO, Guilherme. "Se trabalharmos só no horário comercial, não recebemos nada". Repórter Brasil, São Paulo, 27 ago. 2012. Disponível em:

$<\mathrm{http}: / /$ www.reporterbrasil.org.br/exibe.php?id=2101>. Acesso em: 30 ago. 2012

ZONTINI, E. 'Transnational families', Sloan Work and Family Research Network Encyclopedia Entry. Disponível em: $<$ https://workfamily.sas.upenn.edu/wfrnrepo/object/be4md40po6iq2g3x>. Acesso em: 30 ago. 2012. 